Cochrane Database of Systematic Reviews

\title{
Drugs for treating urinary schistosomiasis (Review)
}

Kramer CV, Zhang F, Sinclair D, Olliaro PL

Kramer CV, Zhang F, Sinclair D, Olliaro PL.

Drugs for treating urinary schistosomiasis.

Cochrane Database of Systematic Reviews 2014, Issue 8. Art. No.: CD000053.

DOI: 10.1002/14651858.CD000053.pub3. 
TABLE OF CONTENTS

HEADER

ABSTRACT

PLAIN LANGUAGE SUMMARY

SUMMARY OF FINDINGS

BACKGROUND

OBJECTIVES

METHODS

RESULTS

Figure 1.

Figure 2.

DISCUSSION

AUTHORS' CONCLUSIONS

ACKNOWLEDGEMENTS

REFERENCES

CHARACTERISTICS OF STUDIES

DATA AND ANALYSES

Analysis 1.1. Comparison 1 Praziquantel $40 \mathrm{mg} / \mathrm{kg}$ single dose versus placebo, Outcome 1 Parasitological failure. ..................

Analysis 1.2. Comparison 1 Praziquantel $40 \mathrm{mg} / \mathrm{kg}$ single dose versus placebo, Outcome 2 Haematuria at eight weeks. ...........

Analysis 1.3. Comparison 1 Praziquantel $40 \mathrm{mg} / \mathrm{kg}$ single dose versus placebo, Outcome 3 Haemoglobin.

Analysis 1.4. Comparison 1 Praziquantel $40 \mathrm{mg} / \mathrm{kg}$ single dose versus placebo, Outcome 4 Adverse events.

Analysis 2.1. Comparison 2 Praziquantel $40 \mathrm{mg} / \mathrm{kg}$ single dose versus lower doses, Outcome 1 Parasitological failure at four to six weeks.

Analysis 2.2. Comparison 2 Praziquantel $40 \mathrm{mg} / \mathrm{kg}$ single dose versus lower doses, Outcome 2 Parasitological failure at two to three months.

Analysis 2.3. Comparison 2 Praziquantel $40 \mathrm{mg} / \mathrm{kg}$ single dose versus lower doses, Outcome 3 Parasitological failure at six to seven months.

Analysis 2.4. Comparison 2 Praziquantel $40 \mathrm{mg} / \mathrm{kg}$ single dose versus lower doses, Outcome 4 Haematuria at three months. .. Analysis 2.5. Comparison 2 Praziquantel $40 \mathrm{mg} / \mathrm{kg}$ single dose versus lower doses, Outcome 5 Proteinuria at three months. ... Analysis 2.6. Comparison 2 Praziquantel $40 \mathrm{mg} / \mathrm{kg}$ single dose versus lower doses, Outcome 6 Haematuria at six weeks. ........ Analysis 2.7. Comparison 2 Praziquantel $40 \mathrm{mg} / \mathrm{kg}$ single dose versus lower doses, Outcome 7 Proteinuria at six weeks. ......... Analysis 2.8. Comparison 2 Praziquantel $40 \mathrm{mg} / \mathrm{kg}$ single dose versus lower doses, Outcome 8 Haematuria at nine months. ... Analysis 2.9. Comparison 2 Praziquantel $40 \mathrm{mg} / \mathrm{kg}$ single dose versus lower doses, Outcome 9 Proteinuria at nine months. .... Analysis 2.10. Comparison 2 Praziquantel $40 \mathrm{mg} / \mathrm{kg}$ single dose versus lower doses, Outcome 10 Adverse events. ................... Analysis 3.1. Comparison 3 Praziquantel $40 \mathrm{mg} / \mathrm{kg}$ single dose versus $2 \times 20 \mathrm{mg} / \mathrm{kg}$ split dose, Outcome 1 Parasitological failure.

Analysis 3.2. Comparison 3 Praziquantel $40 \mathrm{mg} / \mathrm{kg}$ single dose versus $2 \times 20 \mathrm{mg} / \mathrm{kg}$ split dose, Outcome 2 Adverse events. ...... Analysis 4.1. Comparison 4 Praziquantel $40 \mathrm{mg} / \mathrm{kg}$ single dose versus praziquantel $2 \times 40 \mathrm{mg} / \mathrm{kg}$ or $3 \times 40 \mathrm{mg} / \mathrm{kg}$, Outcome 1 Praziquantel $40 \mathrm{mg} / \mathrm{single}$ dose versus praziquantel $2 \times 40 \mathrm{mg} / \mathrm{kg}$ : parasitological failure.

Analysis 4.2. Comparison 4 Praziquantel $40 \mathrm{mg} / \mathrm{kg}$ single dose versus praziquantel $2 \times 40 \mathrm{mg} / \mathrm{kg}$ or $3 \times 40 \mathrm{mg} / \mathrm{kg}$, Outcome 2 Praziquantel $40 \mathrm{mg} / \mathrm{kg}$ single dose versus praziquantel $3 \times 40 \mathrm{mg} / \mathrm{kg}$ : parasitological failure.

Analysis 4.3. Comparison 4 Praziquantel $40 \mathrm{mg} / \mathrm{kg}$ single dose versus praziquantel $2 \times 40 \mathrm{mg} / \mathrm{kg}$ or $3 \times 40 \mathrm{mg} / \mathrm{kg}$, Outcome 3 Praziquantel $40 \mathrm{mg} /$ single dose versus praziquantel $2 \times 40 \mathrm{mg} / \mathrm{kg}$ : microhaematuria at six months.

Analysis 5.1. Comparison 5 Praziquantel $40 \mathrm{mg} / \mathrm{kg}$ single dose versus multiple doses, Outcome 1 Parasitological failure. ........ Analysis 5.2. Comparison 5 Praziquantel $40 \mathrm{mg} / \mathrm{kg}$ single dose versus multiple doses, Outcome 2 Haematuria.

Analysis 6.1. Comparison 6 Metrifonate single dose $(10 \mathrm{mg} / \mathrm{kg})$ versus placebo, Outcome 1 Parasitological failure. ..................... Analysis 6.2. Comparison 6 Metrifonate single dose $(10 \mathrm{mg} / \mathrm{kg})$ versus placebo, Outcome 2 Haemoglobin.

Analysis 7.1. Comparison 7 Metrifonate multiple doses versus placebo, Outcome 1 Parasitological failure.

Analysis 7.2. Comparison 7 Metrifonate multiple doses versus placebo, Outcome 2 Haemoglobin.

Analysis 8.1. Comparison 8 Metrifonate multiple doses versus single dose, Outcome 1 Parasitological failure at one month. ... Analysis 8.2. Comparison 8 Metrifonate multiple doses versus single dose, Outcome 2 Parasitological failure at four months. .. Analysis 9.1. Comparison 9 Metrifonate 3 doses 2 weeks apart: $7.5 \mathrm{mg} / \mathrm{kg}$ versus $5 \mathrm{mg} / \mathrm{kg}$, Outcome 1 Parasitological failure. .. Analysis 9.2. Comparison 9 Metrifonate 3 doses 2 weeks apart: $7.5 \mathrm{mg} / \mathrm{kg}$ versus $5 \mathrm{mg} / \mathrm{kg}$, Outcome 2 Adverse events. 
Analysis 10.1. Comparison 10 Praziquantel versus metrifonate, Outcome 1 Praziquantel $40 \mathrm{mg} / \mathrm{kg}$ single dose versus metrifonate $10 \mathrm{mg} / \mathrm{kg}$ single dose: parasitological failure.

Analysis 10.2. Comparison 10 Praziquantel versus metrifonate, Outcome 2 Praziquantel $40 \mathrm{mg} / \mathrm{kg}$ single dose versus metrifonate $10 \mathrm{mg} / \mathrm{kg}$ single dose: haemoglobin.

Analysis 10.3. Comparison 10 Praziquantel versus metrifonate, Outcome 3 Praziquantel $40 \mathrm{mg} / \mathrm{kg}$ single dose versus metrifonate 20 and $30 \mathrm{mg} / \mathrm{kg}$ given as split doses: parasitological failure.

Analysis 10.4. Comparison 10 Praziquantel versus metrifonate, Outcome 4 Praziquantel $40 \mathrm{mg} / \mathrm{kg}$ single dose versus metrifonate $30 \mathrm{mg} / \mathrm{kg}$ given as split dose: adverse events.

Analysis 10.5. Comparison 10 Praziquantel versus metrifonate, Outcome 5 Praziquantel $30 \mathrm{mg} / \mathrm{kg}$ single dose versus metrifonate $30 \mathrm{mg} / \mathrm{kg}$ given as split dose: parasitological failure.

Analysis 10.6. Comparison 10 Praziquantel versus metrifonate, Outcome 6 Praziquantel $30 \mathrm{mg} / \mathrm{kg}$ single dose versus metrifonate $30 \mathrm{mg} / \mathrm{kg}$ given as split dose: adverse events.

Analysis 10.7. Comparison 10 Praziquantel versus metrifonate, Outcome 7 Praziquantel $40 \mathrm{mg} / \mathrm{kg}$ once a year versus metrifonate $10 \mathrm{mg} / \mathrm{kg}$ every 4 months.

Analysis 10.8. Comparison 10 Praziquantel versus metrifonate, Outcome 8 Praziquantel $40 \mathrm{mg} / \mathrm{kg}$ once a year versus metrifonate $10 \mathrm{mg} / \mathrm{kg}$ every 4 months: parasitological failure.

Analysis 10.9. Comparison 10 Praziquantel versus metrifonate, Outcome 9 Praziquantel $40 \mathrm{mg} / \mathrm{kg}$ versus praziquantel $10 \mathrm{mg} /$ $\mathrm{kg}$ and metrifonate $10 \mathrm{mg} / \mathrm{kg}$.

Analysis 11.1. Comparison 11 Artesunate versus placebo, Outcome 1 Parasitological failure at eight weeks.

Analysis 11.2. Comparison 11 Artesunate versus placebo, Outcome 2 Haematuria.

Analysis 11.3. Comparison 11 Artesunate versus placebo, Outcome 3 Adverse events.

Analysis 12.1. Comparison 12 Praziquantel versus artesunate, Outcome 1 Parasitological failure.

Analysis 12.2. Comparison 12 Praziquantel versus artesunate, Outcome 2 Haematuria.

Analysis 12.3. Comparison 12 Praziquantel versus artesunate, Outcome 3 Adverse events.

Analysis 13.1. Comparison 13 Praziquantel and artesunate versus praziquantel, Outcome 1 Parasitological failure at eight weeks.

Analysis 13.2. Comparison 13 Praziquantel and artesunate versus praziquantel, Outcome 2 Haematuria at eight weeks. .........

Analysis 13.3. Comparison 13 Praziquantel and artesunate versus praziquantel, Outcome 3 Adverse events. ..........................

Analysis 14.1. Comparison 14 Mefloquine versus placebo, Outcome 1 Parasitological failure at six weeks.

Analysis 15.1. Comparison 15 Praziquantel versus mefloquine, Outcome 1 Parasitological failure at one month.

Analysis 16.1. Comparison 16 Praziquantel versus artesunate and mefloquine, Outcome 1 Parasitological failure at one month.

Analysis 17.1. Comparison 17 Praziquantel versus praziquantel and albendazole, Outcome 1 Parasitological failure. .............

Analysis 18.1. Comparison 18 Praziquantel versus praziquantel and artesunate, Outcome 1 Parasitological failure at eight weeks.

Analysis 18.2. Comparison 18 Praziquantel versus praziquantel and artesunate, Outcome 2 Haematuria at eight weeks. ........

Analysis 18.3. Comparison 18 Praziquantel versus praziquantel and artesunate, Outcome 3 Adverse events. 
[Intervention Review]

\title{
Drugs for treating urinary schistosomiasis
}

Christine V Kramer ${ }^{1}$, Fan Zhang², David Sinclair ${ }^{3}$, Piero L Olliaro ${ }^{4}$

1Cochrane Infectious Diseases Group, Liverpool School of Tropical Medicine, Liverpool, UK. 2School of Public Health and Management, Chongqing Medical University, Chongqing, China. ${ }^{3}$ Department of Clinical Sciences, Liverpool School of Tropical Medicine, Liverpool, UK. 4UNICEF/UNDP/World Bank/WHO Special Programme for Research and Training in Tropical Diseases (TDR), World Health Organization, Geneva, Switzerland

Contact address: Christine V Kramer, Cochrane Infectious Diseases Group, Liverpool School of Tropical Medicine, Pembroke Place, Liverpool, L3 5QA, UK. cvkramer@liverpool.ac.uk.

Editorial group: Cochrane Infectious Diseases Group

Publication status and date: Unchanged, published in Issue 8, 2014.

Citation: Kramer CV, Zhang F, Sinclair D, Olliaro PL. Drugs for treating urinary schistosomiasis. Cochrane Database of Systematic Reviews 2014, Issue 8. Art. No.: CD000053. DOI: 10.1002/14651858.CD000053.pub3.

Copyright ( $\odot 2014$ The Authors. Cochrane Database of Systematic Reviews published by John Wiley \& Sons, Ltd. on behalf of The Cochrane Collaboration. This is an open access article under the terms of the Creative Commons Attribution-Non-Commercial Licence, which permits use, distribution and reproduction in any medium, provided the original work is properly cited and is not used for commercial purposes.

\begin{abstract}
A B S T R A C T

\section{Background}

Urinary schistosomiasis is caused by an intravascular infection with parasitic Schistosoma haematobium worms. The adult worms typically migrate to the venous plexus of the human bladder and excrete eggs which the infected person passes in their urine. Chronic infection can cause substantial morbidity and long-term complications as the eggs become trapped in human tissues causing inflammation and fibrosis. We summarised evidence of drugs active against the infection. This is new edition of a review first published in 1997.
\end{abstract}

\section{Objectives}

To evaluate the efficacy and safety of drugs for treating urinary schistosomiasis.

\section{Search methods}

We searched the Cochrane Infectious Diseases Group Specialized Register, MEDLINE, CENTRAL, EMBASE and LILACS and reference lists of articles up to 23 May 2014.

\section{Selection criteria}

Randomized controlled trials (RCTs) of antischistosomal drugs and drug combinations compared to placebo, no intervention, or each other.

\section{Data collection and analysis}

Two researchers independently screened the records, extracted the data and assessed risk of bias. The primary efficacy outcomes were parasitological failure (defined as the continued presence of S. haematobium eggs in the urine at time points greater than one month after treatment), and percent reduction of egg counts from baseline. We presented dichotomous data as risk ratios (RR), and continuous data as mean difference (MD), alongside their 95\% confidence intervals (Cls). Where appropriate we combined trials in meta analyses or tables. We assessed the quality of evidence using the GRADE approach.

\section{Main results}

We included 30 RCTs enrolling 8165 participants in this review. Twenty-four trials were conducted in children in sub-Saharan Africa, and 21 trials were over 20 years old. Many studies were assessed as being at unclear risk of bias due to inadequate descriptions of study methods. 
Praziquantel

On average, a single $40 \mathrm{mg} / \mathrm{kg}$ dose of praziquantel reduced the proportion of people still excreting eggs in their urine by around $60 \%$ compared to placebo at one to two months after treatment (treatment failure: RR $0.42,95 \% \mathrm{Cl} 0.29$ to 0.59 , 864 participants, seven trials, high quality evidence). The proportion of people cured with praziquantel varied substantially between trials, from $22.5 \%$ to $83.3 \%$, but was higher than $60 \%$ in five of the seven trials. At one to two months following praziquantel treatment at $40 \mathrm{mg} / \mathrm{kg}$, the mean number of schistosome eggs in the urine was reduced by over $95 \%$ in five out of six trials (678 participants, six trials, high quality evidence).

Splitting praziquantel $40 \mathrm{mg} / \mathrm{kg}$ into two doses over 12 hours probably has no benefits over a single dose, and in a single trial of 220 participants the split dose caused more vomiting ( $R R 0.5,95 \% \mathrm{Cl} 0.29$ to 0.86 ) and dizziness ( $\mathrm{RR} 0.39,95 \% \mathrm{Cl} 0.16$ to 0.94 ).

\section{Metrifonate}

A single dose of metrifonate $10 \mathrm{mg} / \mathrm{kg}$ reduced egg excretion (210 participants, one trial, at eight months), but was only marginally better than placebo at achieving cure at one month (RR $0.83,95 \% \mathrm{Cl} 0.74$ to $0.94,142$ participants, one trial). In a single trial comparing one, two and three doses, the absolute number of participants cured improved from $47 \%$ after one dose to $81 \%$ after three doses (93 participants, one trial, low quality evidence).

Two small trials compared $40 \mathrm{mg} / \mathrm{kg}$ single dose praziquantel with two or three doses of $10 \mathrm{mg} / \mathrm{kg}$ metrifonate and found no clear evidence of differences in cure (metrifonate $2 \times 10 \mathrm{mg} / \mathrm{kg}$ at one month: RR $1.03,95 \% \mathrm{Cl} 0.8$ to $1.34,72$ participants, one trial; metrifonate $3 \times 10$ $\mathrm{mg} / \mathrm{kg}$ at three months: RR $0.33,95 \% \mathrm{Cl} 0.07$ to $1.57,100$ participants, one trial. In one trial both drugs performed badly and in one trial both performed well.

\section{Other drugs}

Three trials have evaluated the antimalarial artesunate; with inconsistent results. Substantial antischistosomal effects were only seen in one of the three trials, which was at unclear risk of bias due to poor reporting of the trial methods. Similarly, another anti-malarial mefloquine has been evaluated in two small trials with inconsistent effects.

Adverse events were described as mild for all evaluated drugs, but adverse event monitoring and reporting was generally of low quality.

\section{Authors' conclusions}

Praziquantel $40 \mathrm{mg} / \mathrm{kg}$ is the most studied drug for treating urinary schistosomiasis, and has the strongest evidence base.

Potential strategies to improve future treatments for schistosomiasis include the combination of praziquantel with metrifonate, or with antimalarial drugs with antischistosomal properties such as artesunate and mefloquine. Evaluation of these combinations requires rigorous, adequately powered trials using standardized outcome measures.

\section{April 2019}

Update pending

Studies awaiting assessment

The CIDG is currently examining a new search conducted in April 2019 for potentially relevant studies. These studies have not yet been incorporated into this Cochrane Review.

\section{PLAIN LANGUAGESUMMARY}

\section{Drugs for treating urinary schistosomiasis}

\section{What is urinary schistosomiasis and how is it treated?}

Urinary schistosomiasis is a disease caused by infection of people with the parasitic worm Schistosoma haematobium. These worms live in blood vessels around the infected person's bladder and the worm releases eggs which are released in the person's urine. If the urine is passed into ponds or lakes, the eggs can hatch and infect people that are washing or swimming there. Infection can cause blood in the urine and if left untreated can eventually lead to anaemia, malnutrition, kidney failure, or bladder cancer. Urinary schistosomiasis is diagnosed by looking for worm eggs in the urine.

The disease occurs mainly in school-aged children and young adults in sub-Saharan Africa. The drug currently recommended for treatment is praziquantel, which can be given as a single dose, but other drugs such as metrifonate, artesunate, and mefloquine have also been evaluated.

After examining the research published up to 23th May 2014, we included 30 randomized controlled trials, enrolling 8165 children and adults. 


\section{What does the research say?}

On average, the standard dose of praziquantel cures around $60 \%$ of people at one to two months after treatment (high quality evidence), and reduces the number of schistosome eggs in the urine by over 95\% (high quality evidence).

Metrifonate, an older drug no longer in use, had little effect when given as a single dose but an improved effect when given as multiple doses two weeks apart. Two trials compared three doses of metrifonate with the single dose of praziquantel and found similar effects.

Two more recent trials evaluated a combination of artesunate and praziquantel compared to praziquantel alone. In one trial artesunate improved cure and in one it made no difference.

\section{Authors conclusions}

Future treatments for schistosomiasis could include combining praziquantel with metrifonate, or with artesunate, but these need to be evaluated in high quality trials. 


\section{SUMMARY OF FINDINGS}

\section{Summary of findings for the main comparison. Praziquantel $\mathbf{4 0} \mathrm{mg} / \mathrm{kg}$ versus placebo for treating urinary schistosomiasis}

Praziquantel $40 \mathrm{mg} / \mathrm{kg}$ versus placebo for treating urinary schistosomiasis

Patient or population: People with urinary schistosomiasis

Settings: Endemic areas in sub-Saharan Africa

Intervention: Praziquantel $40 \mathrm{mg} / \mathrm{kg}$ (single dose) versus placebo

\begin{tabular}{|c|c|c|c|c|c|}
\hline \multirow[t]{3}{*}{ Outcomes } & \multicolumn{2}{|l|}{ Illustrative comparative risks* $(95 \% \mathrm{CI})$} & \multirow{3}{*}{$\begin{array}{l}\text { Relative ef- } \\
\text { fect } \\
(95 \% \mathrm{CI})\end{array}$} & \multirow{3}{*}{$\begin{array}{l}\text { No of partici- } \\
\text { pants } \\
\text { (trials) }\end{array}$} & \multirow{3}{*}{$\begin{array}{l}\text { Quality of the } \\
\text { evidence } \\
\text { (GRADE) }\end{array}$} \\
\hline & Assumed risk & Corresponding risk & & & \\
\hline & Placebo & Praziquantel 40 mg/kg & & & \\
\hline $\begin{array}{l}\text { Parasitological failure } \\
\text { At } 1 \text { to } 2 \text { months }\end{array}$ & 91 per 100 & $\begin{array}{l}\mathbf{3 8} \text { per } 100 \\
\text { (26 to } 54)\end{array}$ & $\begin{array}{l}\text { RR } 0.42 \\
(0.29 \text { to } 0.59)\end{array}$ & $\begin{array}{l}864 \\
\text { (7 trials) }\end{array}$ & $\begin{array}{l}\oplus \oplus \oplus \oplus \\
\text { high } 1,2,3,4\end{array}$ \\
\hline $\begin{array}{l}\text { Percentage egg reduc- } \\
\text { tion } \\
\text { At } 1 \text { to } 2 \text { months }\end{array}$ & $\begin{array}{l}\text { Mean change in egg excretion in the } \\
\text { control groups ranged from a } \mathbf{5 3 . 2} \% \\
\text { reduction to a } \mathbf{1 3 8 \%} \text { increase. }\end{array}$ & $\begin{array}{l}\text { Mean egg excretion in the intervention groups } \\
\text { was reduced by }>\mathbf{9 8 \%} \text { in all trials }\end{array}$ & Not pooled & $\begin{array}{l}678 \\
(6 \text { trials })\end{array}$ & $\begin{array}{l}\oplus \oplus \oplus \oplus \\
\text { high }^{1,2,3,5}\end{array}$ \\
\hline $\begin{array}{l}\text { Microhaematuria } \\
\text { At } 8 \text { weeks }\end{array}$ & 53 per 100 & $\begin{array}{l}\mathbf{2 8} \text { per } 100 \\
\text { (17 to } 45)\end{array}$ & $\begin{array}{l}\mathbf{R R} \mathbf{0 . 5 3} \\
(0.33 \text { to } 0.84)\end{array}$ & $\begin{array}{l}119 \\
\text { (1 trial) }\end{array}$ & $\begin{array}{l}\oplus \oplus \odot \ominus \\
\text { low }^{6,7,8}\end{array}$ \\
\hline $\begin{array}{l}\text { Haemoglobin } \\
\text { At } 6 \text { to } 8 \text { months }\end{array}$ & $\begin{array}{l}\text { The mean haemoglobin ranged across } \\
\text { control groups from } \\
\mathbf{1 1 . 3} \text { to } \mathbf{1 1 . 9} \mathbf{~ G / d L}\end{array}$ & $\begin{array}{l}\text { The mean haemoglobin in the intervention } \\
\text { groups was } \mathbf{0 . 0 8} \mathbf{~ G / d L} \text { lower } \\
\text { (0.24 lower to } 0.09 \text { higher) }\end{array}$ & - & $\begin{array}{l}727 \\
(2 \text { trials })\end{array}$ & $\begin{array}{l}\oplus \oplus \oplus \ominus \\
\text { moderate } 3,9,10 \\
11\end{array}$ \\
\hline Adverse events & - & - & - & $\begin{array}{l}1591 \\
\text { (9 trials) }\end{array}$ & $\begin{array}{l}\oplus \oplus \ominus \ominus \\
\text { low12 }\end{array}$ \\
\hline
\end{tabular}

The basis for the assumed risk is the mean risk in the control groups across trials. The corresponding risk (and its $95 \% \mathrm{Cl}$ ) is based on the assumed risk in the comparison group and the relative effect of the intervention (and its $95 \% \mathrm{Cl}$ ).

Cl: Confidence interval; RR: Risk ratio.

GRADE Working Group grades of evidence

High quality: Further research is very unlikely to change our confidence in the estimate of effect.

Moderate quality: Further research is likely to have an important impact on our confidence in the estimate of effect and may change the estimate.

Low quality: Further research is very likely to have an important impact on our confidence in the estimate of effect and is likely to change the estimate.

Very low quality: We are very uncertain about the estimate. 
1 No serious risk of bias: Several trials were at unclear or low risk of selection bias. However, a sensitivity analysis excluding these trials still found a strong effect.

2 No serious inconsistency: Six of the seven trials found large consistent effects. The seventh trial found no difference, this may be explained by the different diagnostic criteria used in this trial.

3 No serious indirectness: These seven trials are all conducted in children in endemic areas of sub-Saharan Africa.

4 No serious imprecision: The result is statistically significant and the $95 \% \mathrm{Cl}$ is narrow around a clinically important effect.

5 No serious imprecision: The trials are small and most did not report tests of statistical significance, however the differences are large.

6 No serious risk of bias: This trial was well conducted.

7 Downgraded by 1 for serious indirectness: Only a single trial reports this outcome. Further trials from different settings would be needed to be confident in this effect.

8 Downgraded by 1 for serious imprecision: This trial is underpowered.

9 Downgraded by 1 for serious risk of bias: both trials had inadequate sequence generation and allocation concealment.

10 No serious inconsistency: Low statistical heterogeneity.

11 No serious imprecision: only two trials reported this outcome. Cls are narrow. The effect is not statistically significant and does not appear to be clinically important, when compared to the baseline data.

12 Downgraded by 2 for serious risk of bias: Three trials do not comment on adverse events. Six trials made comments that praziquantel was generally well tolerated and no statistically significant differences were noted. However, adverse events were poorly reported in all six trials such that meta-analysis, and assessment of other quality criteria was not possible.

\section{Summary of findings 2. Praziquantel $40 \mathrm{mg} / \mathrm{kg}$ single dose versus $30 \mathrm{mg} / \mathrm{kg}$ single dose}

\section{Praziquantel $40 \mathrm{mg} / \mathrm{kg}$ compared to praziquantel $30 \mathrm{mg} / \mathrm{kg}$ for treating urinary schistosomiasis}

Patient or population: people with urinary schistosomiasis

Settings: endemic areas in Sub-Saharan Africa

Intervention: praziquantel $40 \mathrm{mg} / \mathrm{kg}$ (single dose)

Comparison: praziquantel $30 \mathrm{mg} / \mathrm{kg}$ (single dose)

\begin{tabular}{|c|c|c|c|c|c|}
\hline \multirow[t]{3}{*}{ Outcomes } & \multicolumn{2}{|c|}{ Illustrative comparative risks* $(95 \% \mathrm{CI})$} & \multirow{3}{*}{$\begin{array}{l}\text { Relative effect } \\
(95 \% \mathrm{CI})\end{array}$} & \multirow{3}{*}{$\begin{array}{l}\text { No of partici- } \\
\text { pants } \\
\text { (trials) }\end{array}$} & \multirow{3}{*}{$\begin{array}{l}\text { Quality of the } \\
\text { evidence } \\
\text { (GRADE) }\end{array}$} \\
\hline & Assumed risk & Corresponding risk & & & \\
\hline & Praziquantel $30 \mathrm{mg} / \mathrm{kg}$ single dose & Praziquantel 40 mg/kg single dose & & & \\
\hline $\begin{array}{l}\text { Parasitological failure } \\
\text { At } 1 \text { month }\end{array}$ & 32 per 100 & $\begin{array}{l}\mathbf{2 4} \text { per } \mathbf{1 0 0} \\
\text { (19 to } 32)\end{array}$ & $\begin{array}{l}\text { RR } \mathbf{0 . 7 6} \\
(0.59 \text { to } 0.99)\end{array}$ & $\begin{array}{l}401 \\
\text { (4 trials) }\end{array}$ & $\begin{array}{l}\oplus \oplus \ominus \ominus \\
\text { low } 1,2,3,4\end{array}$ \\
\hline $\begin{array}{l}\text { Parasitological failure } \\
\text { At } 6 \text { months }\end{array}$ & 29 per 100 & $\begin{array}{l}\mathbf{2 8} \text { per } \mathbf{1 0 0} \\
\text { (22 to } 36 \text { ) }\end{array}$ & $\begin{array}{l}\text { RR } 0.97 \\
\text { (0.76 to } 1.23 \text { ) }\end{array}$ & $\begin{array}{l}669 \\
\text { (6 trials) }\end{array}$ & $\begin{array}{l}\oplus \oplus \oplus \ominus \\
\text { moderate }\end{array}$ \\
\hline
\end{tabular}




\begin{tabular}{|c|c|c|c|c|c|}
\hline \multirow[b]{2}{*}{$\begin{array}{l}\text { Mean percent egg re- } \\
\text { duction } \\
\text { At } 6 \text { months }\end{array}$} & \multirow[b]{2}{*}{$\begin{array}{l}\text { The mean reduction in control } \\
\text { groups ranged from an } \mathbf{9 7 \%} \text { reduc- } \\
\text { tion to a } \mathbf{9 9 \%} \text { reduction. }\end{array}$} & \multirow[b]{2}{*}{$\begin{array}{l}\text { The mean reduction in the intervention } \\
\text { groups ranged from a } \mathbf{4 6 \%} \text { reduction } 15 \text { to a } \\
\mathbf{9 9 \%} \text { reduction }\end{array}$} & & \multicolumn{2}{|r|}{$1,3,7,8$} \\
\hline & & & Not pooled & $\begin{array}{l}362 \\
\text { (4 trials) }\end{array}$ & $\begin{array}{l}\oplus \oplus \Theta \Theta \\
\text { low }^{1,3,9,10}\end{array}$ \\
\hline Haematuria & 26 per 100 & $\begin{array}{l}23 \text { per } 1000 \\
\text { (12 to } 44)\end{array}$ & $\begin{array}{l}\text { RR } 0.89 \\
(0.47 \text { to } 1.67)\end{array}$ & $\begin{array}{l}117 \\
\text { (1 trial) }\end{array}$ & $\begin{array}{l}\oplus \odot \odot \ominus \\
\text { very low } 11,12,13\end{array}$ \\
\hline Proteinuria & 15 per 100 & $\begin{array}{l}\mathbf{1 3} \text { per } 100 \\
(5 \text { to } 31)\end{array}$ & $\begin{array}{l}\mathbf{R R} \mathbf{0 . 8 5} \\
(0.34 \text { to } 2.12)\end{array}$ & $\begin{array}{l}117 \\
\text { (1 trial) }\end{array}$ & $\begin{array}{l}\oplus \ominus \ominus \ominus \\
\text { very low 11,12,13 }\end{array}$ \\
\hline Adverse events & - & - & Not estimable & $\begin{array}{l}992 \\
\text { (8 trials) }\end{array}$ & $\begin{array}{l}\oplus \oplus \odot \ominus \\
\text { low } 14\end{array}$ \\
\hline
\end{tabular}

*The basis for the assumed risk (for example, the median control group risk across studies) is provided in footnotes. The corresponding risk (and its $95 \% \mathrm{Cl}$ ) is based on the assumed risk in the comparison group and the relative effect of the intervention (and its $95 \% \mathrm{Cl}$ ).

Cl: Confidence interval; RR: Risk ratio.

GRADE Working Group grades of evidence

High quality: Further research is very unlikely to change our confidence in the estimate of effect.

Moderate quality: Further research is likely to have an important impact on our confidence in the estimate of effect and may change the estimate.

Low quality: Further research is very likely to have an important impact on our confidence in the estimate of effect and is likely to change the estimate.

Very low quality: We are very uncertain about the estimate.

1 Downgraded by 1 for serious risk of bias: None of the trials described a method of allocations concealment or blinding outcome assessors.

2 No serious inconsistency: No statistical heterogeneity in the relative effect of the two praziquantel doses. However, treatment failure with praziquantel $40 \mathrm{mg} / \mathrm{kg}$ ranged from $0 \%$ to than more than $50 \%$

3 No serious indirectness: All trials were conducted in sub-Saharan Africa, in patients aged from seven to 20 years.

4 Downgraded by 1 for serious imprecision: None of the individual studies found statistical significant differences, and overall, the meta-analysis remains underpowered to confidently detect an effect.

5 No serious inconsistency: Three of the four trials report the difference was not statistically significant. The fourth trial did not report significance but effects were similar.

6 Downgraded by 1 for serious imprecision: We were unable to pool the data, and as such cannot exclude a small difference in effect between the two doses in a pooled analysis.

7 No serious inconsistency. Low statistical heterogeneity.

8 No serious imprecision. The effect is of no clinically important difference between the two doses, and the $95 \%$ Cls are narrow.

9 Downgraded by 1 for serious inconsistency: In one trial praziquantel $40 \mathrm{mg} / \mathrm{kg}$ had a very low percent egg reduction of $46 \%$. The reasons for this are unclear.

10 Unable to assess precision as the data were not pooled.

11 Downgraded by 1 for serious risk of bias: This trial did not adequately describe allocation concealment. Participants and clinicians were not blinded.

12 Downgraded by 1 for serious indirectness: Only one trial from one setting.

13 Downgraded by 1 for serious imprecision. This trial is underpowered to detect an effect. The $95 \% \mathrm{Cl}$ is wide and includes clinically important benefits and no effect.

14 Downgraded by 2 for serious risk of bias. Six out of ten trials comparing praziquantel $40 \mathrm{mg} / \mathrm{kg}$ to lower doses did not comment on adverse events, and of the remaining only two used prospective active surveillance to monitor adverse events. Only two trials out of ten described blinding for clinicians or participants. 


\section{Praziquantel $40 \mathrm{mg} / \mathrm{kg}$ multiple doses compared to single dose for treating urinary schistosomiasis}

Patient or population: patients with treating urinary schistosomiasis

Settings: endemic settings

Intervention: Praziquantel $40 \mathrm{mg} / \mathrm{kg}$ multiple doses (every three months for two years)

Comparison: Praziquantel $40 \mathrm{mg} / \mathrm{kg}$ single dose

\begin{tabular}{|c|c|c|c|c|c|c|}
\hline \multirow[t]{3}{*}{ Outcomes } & \multicolumn{2}{|c|}{ Illustrative comparative risks* $(95 \% \mathrm{Cl})$} & \multirow{3}{*}{$\begin{array}{l}\text { Relative ef- } \\
\text { fect } \\
(95 \% \mathrm{CI})\end{array}$} & \multirow{3}{*}{$\begin{array}{l}\text { No of partici- } \\
\text { pants } \\
\text { (trials) }\end{array}$} & \multirow{3}{*}{$\begin{array}{l}\text { Quality of the evi- } \\
\text { dence } \\
\text { (GRADE) }\end{array}$} & \multirow[t]{3}{*}{ Comments } \\
\hline & Assumed risk & Corresponding risk & & & & \\
\hline & $\begin{array}{l}\text { Praziquantel } 40 \text { mg/kg sin- } \\
\text { gle dose }\end{array}$ & $\begin{array}{l}\text { Praziquantel } 40 \mathrm{mg} / \mathrm{kg} \text { multiple } \\
\text { doses }\end{array}$ & & & & \\
\hline $\begin{array}{l}\text { Parasitological failure } \\
\text { At } 2 \text { years }\end{array}$ & 90 per 100 & $\begin{array}{l}\mathbf{2 4 4} \text { per } \mathbf{1 0 0} \\
(132 \text { to } 450)\end{array}$ & $\begin{array}{l}\text { RR 2.71 } \\
(1.47 \text { to } 5.00)\end{array}$ & $\begin{array}{l}62 \\
(1 \text { trial })\end{array}$ & $\begin{array}{l}\oplus \odot \odot \ominus \\
\text { very low } 1,2,3,4\end{array}$ & \\
\hline $\begin{array}{l}\text { Mean percent egg re- } \\
\text { duction } \\
\text { At } 2 \text { years }\end{array}$ & $\begin{array}{l}\text { This study reports a } \mathbf{8 1 \%} \text { re- } \\
\text { duction after a single dose } \\
\text { of praziquantel }\end{array}$ & $\begin{array}{l}\text { This study reports a96\% reduction } \\
\text { after multiple doses of praziquan- } \\
\text { tel }\end{array}$ & - & $\begin{array}{l}62 \\
(1 \text { trial })\end{array}$ & $\begin{array}{l}\oplus \odot \odot \ominus \\
\text { very low } 1,2,3,4\end{array}$ & \\
\hline $\begin{array}{l}\text { Parasitological failure } \\
\text { At } 3 \text { years }\end{array}$ & 63 per 100 & $\begin{array}{l}\mathbf{5 6} \text { per } \mathbf{1 0 0} \\
(37 \text { to } 89)\end{array}$ & $\begin{array}{l}\text { RR } \mathbf{0 . 9 2} \\
\text { (0.59 to } 1.42)\end{array}$ & $\begin{array}{l}43 \\
(1 \text { trial })\end{array}$ & $\begin{array}{l}\oplus \ominus \ominus \ominus \\
\text { very low } 1,2,3,4\end{array}$ & \\
\hline Adverse events & - & $\begin{array}{l}\text { This study reports a } 96 \% \text { reduction } \\
\text { after multiple doses of praziquan- } \\
\text { tel }\end{array}$ & - & $\begin{array}{l}43 \\
(1 \text { trial })\end{array}$ & $\begin{array}{l}\oplus \odot \odot \odot \\
\text { very low } 5\end{array}$ & \\
\hline
\end{tabular}

*The basis for the assumed risk (for example, the median control group risk across studies) is provided in footnotes. The corresponding risk (and its $95 \% \mathrm{Cl}$ ) is based on the assumed risk in the comparison group and the relative effect of the intervention (and its $95 \% \mathrm{Cl}$ ).

Cl: Confidence interval; RR: Risk ratio;

GRADE Working Group grades of evidence

High quality: Further research is very unlikely to change our confidence in the estimate of effect.

Moderate quality: Further research is likely to have an important impact on our confidence in the estimate of effect and may change the estimate.

Low quality: Further research is very likely to have an important impact on our confidence in the estimate of effect and is likely to change the estimate. 
Very low quality: We are very uncertain about the estimate.

1 Downgraded by 2 for serious risk of bias. The one trial reporting the outcome did not report adequately on sequence generation and blinding. Allocation was not concealed, and loss to follow up was very high.

2 No serious inconsistency: only one trial.

3 No serious indirectness: only one trial.

4 Downgraded by 1 for serious imprecision: This single trial is small and underpowered to reliably detect an effect.

5 This trial did not report on adverse events.

\section{Summary of findings 4. Metrifonate $3 \times 7.5 \mathrm{mg} / \mathrm{kg}$ given two weeks apart versus placebo}

\section{Metrifonate compared to placebo for treating urinary schistosomiasis}

Patient or population: patients with treating urinary schistosomiasis

Settings: endemic settings

Intervention: metrifonate $3 \times 7.5 \mathrm{mg} / \mathrm{kg}$ given two weeks apart

Comparison: placebo

\begin{tabular}{|c|c|c|c|c|c|}
\hline \multirow[t]{3}{*}{ Outcomes } & \multicolumn{2}{|c|}{ Illustrative comparative risks* $(95 \% \mathrm{CI})$} & \multirow{3}{*}{$\begin{array}{l}\text { Relative ef- } \\
\text { fect } \\
(95 \% \mathrm{CI})\end{array}$} & \multirow{3}{*}{$\begin{array}{l}\text { No of partici- } \\
\text { pants } \\
\text { (trials) }\end{array}$} & \multirow{3}{*}{$\begin{array}{l}\text { Quality of the evi- } \\
\text { dence } \\
\text { (GRADE) }\end{array}$} \\
\hline & Assumed risk & Corresponding risk & & & \\
\hline & Placebo & $\begin{array}{l}\text { Metrifonate } 3 \times 7.5 \mathrm{mg} / \mathrm{kg} \text { given } \\
\text { two weeks apart }\end{array}$ & & & \\
\hline Parasitological failure & 40 per 100 & 16 per 100 & RR 0.41 & 93 & $\oplus \oplus \ominus \ominus$ \\
\hline At 2 to 2.5 months & & (12 to 22 ) & (0.3 to 0.56$)$ & (1 trial) & low $1,2,3,4$ \\
\hline $\begin{array}{l}\text { Mean percent egg reduction } \\
\text { At } 2 \text { to } 2.5 \text { months }\end{array}$ & $\begin{array}{l}\text { Egg excretion increased by } \\
131 \% \text { in the placebo group } \\
\text { in this study }\end{array}$ & $\begin{array}{l}\text { Egg excretion was reduced by } 100 \% \\
\text { in this trial }\end{array}$ & - & $\begin{array}{l}93 \\
(1 \text { trial })\end{array}$ & $\begin{array}{l}\oplus \oplus \odot \odot \\
\text { low }^{1,2,3,4}\end{array}$ \\
\hline $\begin{array}{l}\text { Parasitological failure } \\
\text { At } 6 \text { months }\end{array}$ & 96 per 100 & $\begin{array}{l}29 \text { per } 100 \\
\text { (23 to } 36)\end{array}$ & $\begin{array}{l}\mathbf{R R} \mathbf{0 . 3} \\
(0.24 \text { to } 0.37)\end{array}$ & $\begin{array}{l}400 \\
\text { (1 trial) }\end{array}$ & $\begin{array}{l}\oplus \oplus \oplus \ominus \\
\text { moderate } 2,3,5,6\end{array}$ \\
\hline At 6 months & & & & (1 trial) & moderate $2,3,5,7$ \\
\hline Adverse events & - & - & - & 493 & 8 \\
\hline
\end{tabular}


*The basis for the assumed risk (for example, the median control group risk across studies) is provided in footnotes. The corresponding risk (and its $95 \% \mathrm{Cl}$ ) is based on the assumed risk in the comparison group and the relative effect of the intervention (and its $95 \% \mathrm{Cl}$ ).

Cl: Confidence interval; RR: Risk ratio.

GRADE Working Group grades of evidence

High quality: Further research is very unlikely to change our confidence in the estimate of effect.

Moderate quality: Further research is likely to have an important impact on our confidence in the estimate of effect and may change the estimate.

Low quality: Further research is very likely to have an important impact on our confidence in the estimate of effect and is likely to change the estimate.

Very low quality: We are very uncertain about the estimate.

1 Downgraded by 1 for serious risk of bias; the single trial reporting this outcome did not adequately describe sequence generation, allocation concealment and blinding of participants, clinicians or outcome assessors.

2 No serious inconsistency. Only one trial.

3 No serious indirectness. This single trial was conducted in children in rural sub-Saharan Africa.

4 Downgraded by 1 for serious imprecision. The trial was underpowered.

5 Downgraded by 1 for serious risk of bias. The trial did not report on sequence generation and allocation concealment. The study described blinding of participants, clinicians and outcome assessors.

6 No serious imprecision. Cls are narrow and both $\mathrm{Cl}$ limits have clinically important effects. The trial is adequately powered for this outcome.

7 No serious imprecision. The difference in effect between metrifonate and placebo group is large.

8 None of the trials reported on adverse events.

\section{Summary of findings 5. Artesunate versus placebo}

\section{Artesunate compared to placebo for treating urinary schistosomiasis}

Patient or population: patients with treating urinary schistosomiasis

Settings: endemic settings

Intervention: artesunate $4 \mathrm{mg} / \mathrm{kg}$ for three days

Comparison: placebo

\begin{tabular}{|c|c|c|c|c|c|}
\hline \multirow[t]{3}{*}{ Outcomes } & \multicolumn{2}{|c|}{ Illustrative comparative risks* $(95 \% \mathrm{Cl})$} & \multirow{3}{*}{$\begin{array}{l}\text { Relative effect } \\
(95 \% \mathrm{CI})\end{array}$} & \multirow{3}{*}{$\begin{array}{l}\text { No of partici- } \\
\text { pants } \\
\text { (studies) }\end{array}$} & \multirow{3}{*}{$\begin{array}{l}\text { Quality of the evi- } \\
\text { dence } \\
\text { (GRADE) }\end{array}$} \\
\hline & Assumed risk & Corresponding risk & & & \\
\hline & Placebo & Artesunate & & & \\
\hline $\begin{array}{l}\text { Parasitological failure } \\
\text { At } 8 \text { weeks }\end{array}$ & 87 per 100 & $\begin{array}{l}46 \text { per } 100 \\
\text { (14 to } 148)\end{array}$ & $\begin{array}{l}\mathbf{R R} \mathbf{0 . 5 3} \\
(0.16 \text { to } 1.71)\end{array}$ & $\begin{array}{l}251 \\
\text { (2 trials) }\end{array}$ & $\begin{array}{l}\oplus \oplus \ominus \ominus \\
\text { very low } 1,2,3,4\end{array}$ \\
\hline
\end{tabular}




\begin{tabular}{|c|c|c|c|c|c|c|}
\hline 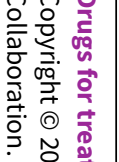 & $\begin{array}{l}\text { Mean percent egg reduc- } \\
\text { tion } \\
\text { At } 8 \text { weeks }\end{array}$ & $\begin{array}{l}\text { Mean change in egg excretion } \\
\text { ranged from range from } \mathbf{4 7 . 1} \% \text { re- } \\
\text { duction to } \mathbf{1 1 1 . 5 \%} \text { increase. }\end{array}$ & $\begin{array}{l}\text { Reduction in egg excretion ranged } \\
\text { from } 52.1 \% \text { to a } 69.3 \%\end{array}$ & - & $\begin{array}{l}276 \\
(2 \text { trials })\end{array}$ & $\begin{array}{l}\oplus \odot \odot \ominus \\
\text { low }^{1,3,5,6}\end{array}$ \\
\hline 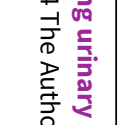 & $\begin{array}{l}\text { Microhaematuria } \\
\text { At } 8 \text { weeks }\end{array}$ & 53 per 100 & $\begin{array}{l}65 \text { per } 100 \\
\text { (45 to } 94)\end{array}$ & $\begin{array}{l}\text { RR } \mathbf{1 . 2 2} \\
\text { (0.85 to } 1.76)\end{array}$ & $\begin{array}{l}119 \\
(1 \text { trial })\end{array}$ & $\begin{array}{l}\oplus \oplus \oplus \ominus \\
\text { low } 7,8,9,10\end{array}$ \\
\hline 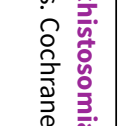 & Adverse events & - & - & - & $\begin{array}{l}276 \\
(2 \text { trials })\end{array}$ & $\begin{array}{l}\oplus \oplus \odot \odot \\
\text { low }^{11,12}\end{array}$ \\
\hline
\end{tabular}

${ }^{\star}$ The basis for the assumed risk (for example, the median control group risk across studies) is provided in footnotes. The corresponding risk (and its $95 \% \mathrm{Cl}$ ) is based on the assumed risk in the comparison group and the relative effect of the intervention (and its $95 \% \mathrm{Cl}$ ).

Cl: Confidence interval; RR: Risk ratio.

GRADE Working Group grades of evidence

High quality: Further research is very unlikely to change our confidence in the estimate of effect.

Moderate quality: Further research is likely to have an important impact on our confidence in the estimate of effect and may change the estimate.

Low quality: Further research is very likely to have an important impact on our confidence in the estimate of effect and is likely to change the estimate.

Very low quality: We are very uncertain about the estimate.

1 Downgraded by 1 for serious risk of bias. One trial described sequence generation, allocation concealment and blinding adequately, whereas the second study did not.

2 Downgraded by 1 for serious inconsistency. One of the trials (at high risk of bias) reported a large effect, while the other trial (at low risk of bias) detected no effect.

3 No serious indirectness. The trials were conducted in Gabon and Nigeria in patients of a similar age range.

4 Downgraded by 1 for serious imprecision. The $\mathrm{Cl}$ is very wide and reaches from no benefit to a significant benefit after treatment.

5 No for serious inconsistency. Percent egg reductions the studies reported were similar.

6 Downgraded by 1 for serious imprecision. The meta analysis is underpowered.

7 No serious risk of bias. The one trial reporting the outcome reported adequately on sequence generation, allocation concealment and blinding.

8 No serious inconsistency: only one trial.

9 No serious indirectness: This trial was conducted in school children in Gabon.

10 Downgraded by 2 for very serious imprecision: only one trial reporting 74 events in 119 participants evaluated this outcome.

11Downgraded by 1 for serious risk of bias: only one trial was blinded. Both trials reported on adverse events, but the methods are unclear.

12 Downgraded by 1 for imprecision. One study reported on clinically diagnosed outcomes per treatment group, but was underpowered to confidently detect a difference.

\section{Summary of findings 6 . Praziquantel and artesunate versus praziquantel}

\section{Praziquantel plus artesunate compared to praziquantel alone for treating urinary schistosomiasis}

Patient or population: patients with urinary schistosomiasis

Settings: Countries endemic for urinary schistosomiasis 
Comparison: Praziquantel alone

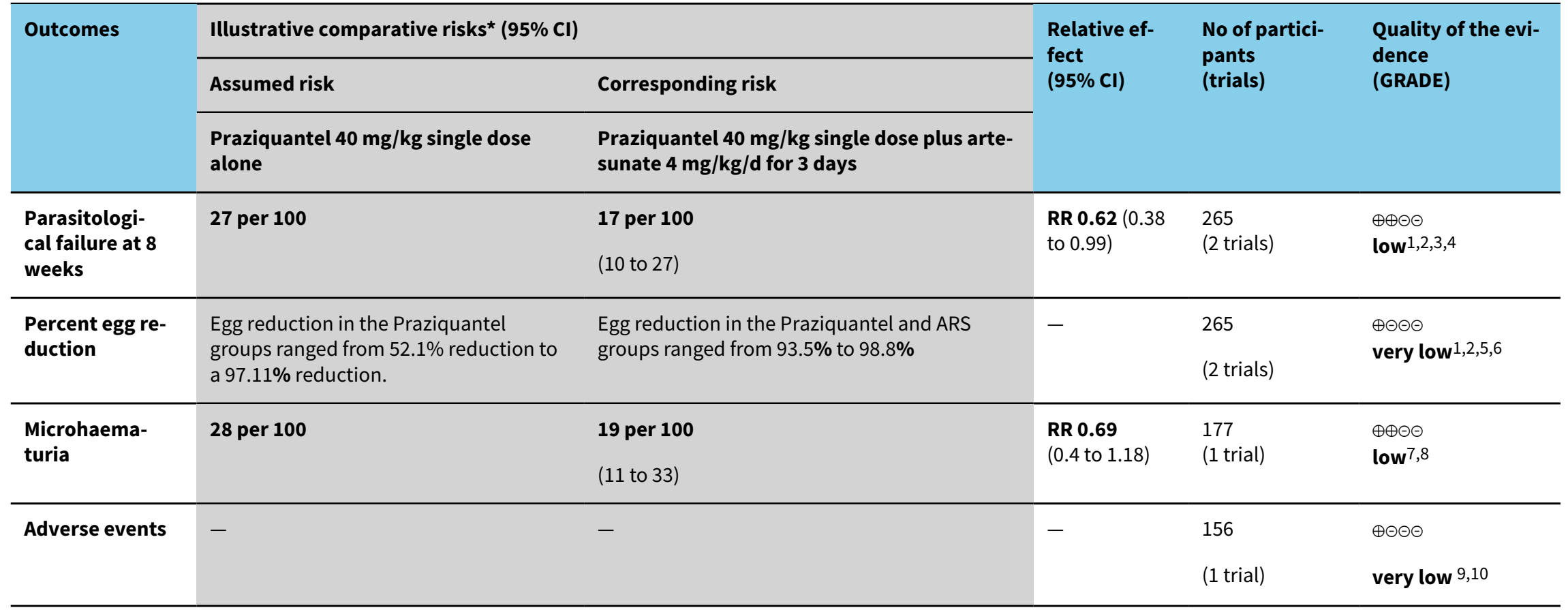

*The basis for the assumed risk (for example, the median control group risk across studies) is provided in footnotes. The corresponding risk (and its $95 \% \mathrm{Cl}$ ) is based on the assumed risk in the comparison group and the relative effect of the intervention (and its $95 \% \mathrm{Cl}$ ).

Cl: Confidence interval; RR: Risk ratio.

GRADE Working Group grades of evidence

High quality: Further research is very unlikely to change our confidence in the estimate of effect.

Moderate quality: Further research is likely to have an important impact on our confidence in the estimate of effect and may change the estimate.

Low quality: Further research is very likely to have an important impact on our confidence in the estimate of effect and is likely to change the estimate.

Very low quality: We are very uncertain about the estimate.

1 Downgraded by 1 for serious risk of bias: only one out of two studies did report adequate random sequence generation, allocation concealment and blinding or participants and clinicians, while the other study did not provide enough information to allow a judgement.

2 No serious inconsistency. Both studies favour the combination of Praziquantel and ARS over Praziquantel alone.

3 No serious indirectness. The trials were conducted in rural communities in Gabon and Nigeria, in children (6 to 15 years) and young adults ( 4 to 20 years)

4 Downgraded by 1 for serious imprecision: Only two studies were included in this comparison. The effect size, described by the $95 \% \mathrm{Cl}$ ranged from a very small, clinically nonimportant effect to a clinically important effect.

5 Downgraded by 1 for serious inconsistency: egg reduction varied widely between the two trials.

6 Downgraded by 1 for serious imprecision: Only two studies reported this outcome.

吕

${ }^{7}$ No serious risk of bias. The one study that reporting this outcome described adequate random sequence generation, allocation concealment and blinding. 


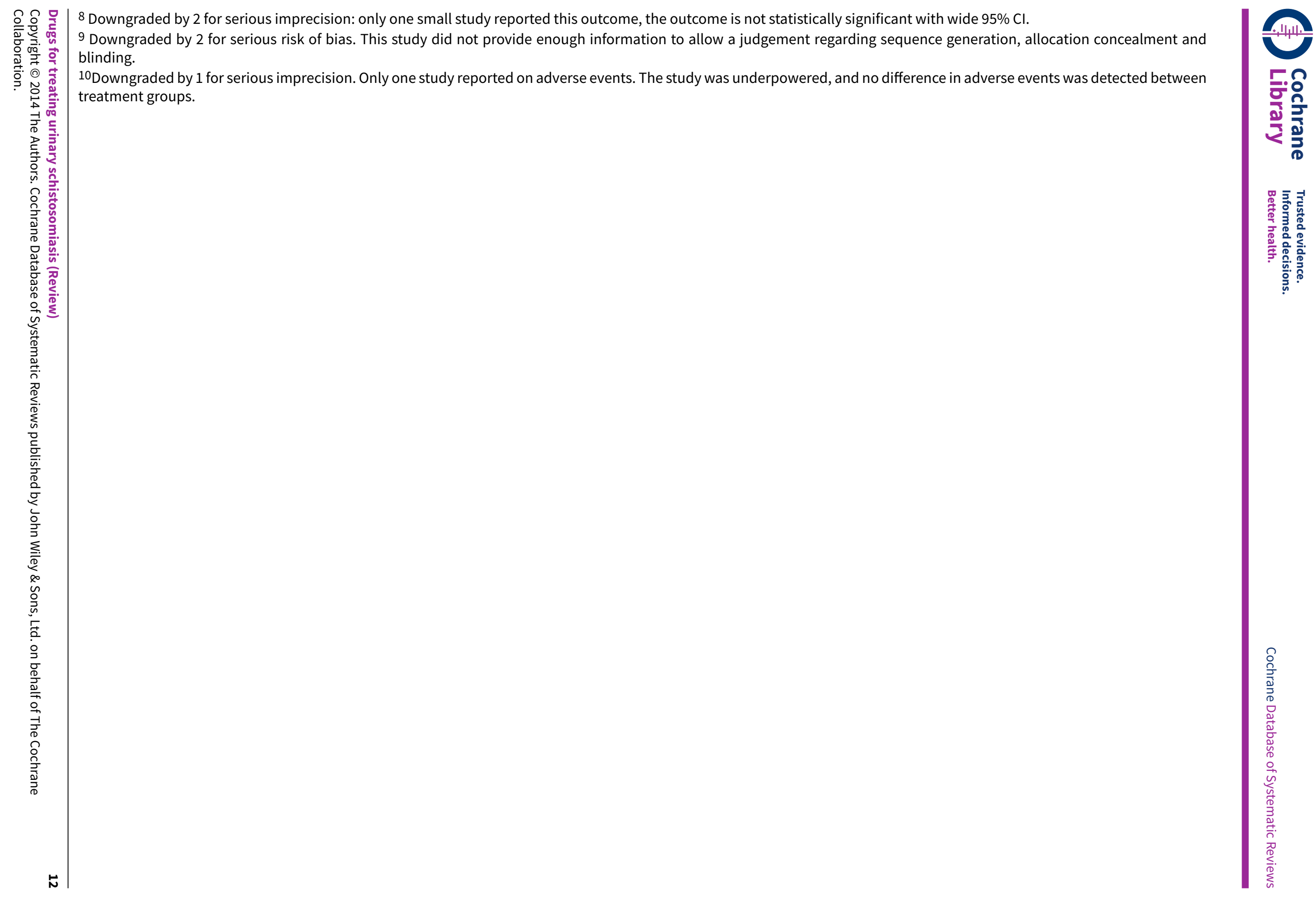




\section{B A C K G R O U N D}

Urinary schistosomiasis, also called bilharzia or snail fever, is an intravascular infection caused by parasitic Schistosoma haematobium worms. It is endemic in sub-Saharan Africa, the Arabian peninsula and the Middle East. According to the World Health Organization (WHO), at least 243 million people required treatment for schistosomiasis in 2011 (WHO 2013), and more than 700 million people live in endemic areas (WHO 2014).

The WHO currently recommends regular chemoprophylaxis with praziquantel for populations at risk to prevent the long term consequences of infection. These programmes usually target school children (Table 1), but may be extended to the whole community in high risk settings (King 2011).

\section{Description of the condition}

Human infection with S. haematobium is acquired through contact with water bodies containing cercariae, the larval form of the parasite. The cercariae are able to penetrate human skin and migrate via blood vessels to the liver, where they mature into male and female forms for reproduction. Typically, they then migrate further to the venous plexus of the urinary bladder, and begin to produce eggs which the infected person excretes in their urine (Gryseels 2006). If these eggs reach water, they hatch into miracidia, infect specific freshwater snails which act as intermediate hosts, before emerging as cercariae that can infect humans (Gray 2011; Ross 2002).

Any illness associated with acute infection is typically mild, but chronic schistosomiasis can cause considerable morbidity with chronic pain, anaemia, fatigue, under nutrition and reduced exercise tolerance (King 2005). A review of 124 observational studies and 11 randomized controlled trials (RCTs) in 2005 estimated that up to $15 \%$ of people infected with any form of schistosomiasis suffer disabling long-term complications (King 2005). The main pathological process occurs when schistosome eggs become trapped in the tissue around the bladder and ureters causing chronic inflammation, which may obstruct the ureters, damage the kidneys, and lead to bladder cancer. Occasionally, eggs can become trapped in other tissues such as the brain and spinal cord (WHO 1985).

Two-thirds of all infected persons are schoolchildren (aged five to 14 years), and the intensity of infection with $S$. haematobium is highest in children aged ten to 14 years (WHO 1985).

The standard test for urinary schistosomiasis is urine filtration and microscopic examination of the urine sample (WHO 1991). The urine sample is passed through a filter paper and the eggs retained on the filter are counted either with or without staining. Sedimentation and centrifugation is less commonly used for urine concentration (Cook 2003). High urine egg counts are related to high infection intensity.

Parasitologists define cure when eggs can no longer be detected in one or more urine samples using standard methods. Besides parasitological cure, researchers also record the relative reduction in egg output after treatment compared to pre-treatment levels. This outcome, expressed as \% egg reduction, is an indirect estimate of a reduction of the worm burden (Cook 2003).
Blood and protein excretion in the urine is usually elevated in urinary schistosomiasis and decreases when the infection resolves. The most commonly used test is a dipstick test. Ultrasound can demonstrate organ involvement of the urinary tract as well as its resolution.

\section{Description of the intervention}

Praziquantel is the current treatment for urinary schistosomiasis recommended by the WHO (WHO 2006). Historically, metrifonate was also used but this fell out of favour due to the need for multiple doses (Feldmeier 1999; WHO 1998). More recently, there has been interest in the antischistosomal properties of artemisinin derivates and mefloquine, more commonly used for treating malaria (Utzinger 2004).

Praziquantel is an pyrazinoisoquinoline derivative with activity against adult worms of all schistosome species (S. mansoni, $S$. intercalatum and S. japonicum), but not against maturing worms. Praziquantel has a rapid onset of action. It is well-tolerated, can be given as a single dose (Utzinger 2004) and paediatric formulations are available (Stothard 2013).

Metrifonate, an organophosphorous cholinesterase inhibitor, is active against $S$. haematobium but not against other schistosome species (Utzinger 2004).

Artemisinin, extensively used as potent antimalarial, has highest activity against immature schistosomes. Artemsinins are safe and well-tolerated (Utzinger 2004).

\section{How the intervention might work}

After treatment with praziquantel, the worms appear to die quickly but egg excretion continues for several weeks. There are several possible reasons for this:

- Firstly, some worms might not have been mature at the time of praziquantel treatment and therefore not killed by praziquantel (Cioli 2003). Maturation of the worms after infection takes four to six weeks, and after two months eggs can be detected in the urine.

- Secondly, the patient might have been re-infected (Cioli 2003).

- Thirdly, dead eggs still wander out of the tissue into the urine several weeks after clearing adult worms (Taylor 1988 ZWE). Therefore, a follow-up four to six weeks after treatment is useful (Renganathan 1998). There is also considerable variation in daily urinary egg output (Cook 2003).

Although there is concern that S. haematobium might develop resistance against praziquantel (Fenwick 2006), there is no clinically relevant evidence for resistance up to now (Doenhoff 2008).

In endemic settings, reinfection with S. haematobium is likely, and cure (often defined as complete cessation of egg excretion) is not a sustainable long term goal. However, reduction of infection intensity results in clinical improvement, low morbidity and prevention of long term complications. Therefore, WHO promotes morbidity control rather than cure as an objective for schistosomiasis control programmes (WHO 2002). 


\section{Why it is important to do this review}

At present, praziquantel as the only drug in use that is exposed to resistance development. It is therefore important to monitor its performance and to assess the effects of other drugs against urinary schistosomiasis.

Dosing regimens for subgroups such as highly infected patient groups, incremental benefits of drug combinations, double dosing and optimal interval between doses have to be determined to inform control programmes for urinary schistosomiasis.

Paediatric schistosomiasis has gained attention as a public health problem, and evaluation of existing treatment studies is indicated.

\section{O B JECT IVES}

To evaluate the efficacy and safety of drugs for treating urinary schistosomiasis.

\section{METHODS}

\section{Criteria for considering studies for this review}

\section{Types of studies}

Randomized controlled trials.

\section{Types of participants}

Patients diagnosed with urinary schistosomiasis by:

- detection of macro or microhaematuria;

- identification of schistosome eggs by urine microscopy;

- detection of parasite antigens in blood or urine.

\section{Types of interventions}

\section{Intervention}

Drugs used to treat urinary schistosomiasis. Drugs considered as obsolete (such as ambilhar, oltipraz and niridazole) were not included. Metrifonate was included.

\section{Control}

Placebo, no intervention, an alternative regimen of the same drug, or an alternative drug used to treat urinary schistosomiasis.

\section{Types of outcome measures}

\section{Primary outcomes}

- Parasitological failure at one month post-treatment (as defined by the trial authors);

- Percent egg reduction at one month.

\section{Secondary outcomes}

- Parasitological failure at time-points > one month;

- Percent egg reduction from baseline at > one month;

- Clinical outcomes: resolutions of signs and symptoms (for example, haematuria and proteinuria);

- Anaemia (decrease of the number of red blood cells or the quantity of haemoglobin in the blood);

- Growth outcomes (gain in body weight, body length).

\section{Adverse events}

- Serious adverse events;

- Other adverse events

\section{Search methods for identification of studies}

We attempted to identify all relevant trials regardless of language and publication status (published, unpublished, in press, under review and in progress).

\section{Electronic searches}

We searched the following databases using the search terms outlined in Appendix 1: The Cochrane Infectious Diseases Group Specialized Register (23 May 2014); Cochrane Central Register of Controlled Trials (CENTRAL), published in The Cochrane Library (2014, Issue 4); MEDLINE (1966 to 23 May 2014); EMBASE (1974 to 23 May 2014); and LILACS (1982 to 23 May 2014). We also searched the metaRegister of Controlled Trials (mRCT) using 'Schistosoma haematobium' as the search term (23 May 2014).

\section{Searching other resources}

We checked the reference lists of all studies identified by the above methods for additional studies relevant to this review.

\section{Data collection and analysis}

\section{Selection of studies}

Vittoria Lutje, the Cochrane Infectious Diseases Group (CIDG) Information Retrieval Specialist, searched the literature and retrieved trial titles and abstracts.

VK and FZ independently screened the results of the search and retrieved full trial reports of all potentially relevant trials. Then, VK and FZ independently assessed each trial for inclusion using an eligibility form based on the inclusion criteria. We resolved any discrepancies by discussion with PG.

\section{Data extraction and management}

VK and FZ independently extracted data using pre-tested standardized forms. We resolved any differences through discussion with PG. For each trial we extracted details of the trial methods, participants, interventions and outcomes.

VK and FZ extracted the number of participants randomized and number of participants followed up in each treatment arm. For dichotomous outcomes, we extracted the number of participants experiencing the event in each group. For continuous outcomes summarized as geometric means, we extracted means and their standard error, if reported. If the data were presented as arithmetic means, we extracted arithmetic means and their standard deviations (SD), if reported, for each treatment group. Where continuous data were summarized as medians and ranges, these were extracted and entered into tables.

VK and FZ double-entered the data and cross-checked to minimise errors. VK tried to contact trial authors for clarification or insufficient of missing data when necessary and summarised data reported in multiple publications as one single data set. 


\section{Assessment of risk of bias in included studies}

VK and FZ independently assessed the risk of bias of each trial using an assessment form based on the Cochrane Collaboration's 'Risk of bias' tool (Higgins 2008). DS verified the assessment results.

We assessed the risk of bias for six domains: sequence generation; allocation concealment; blinding (of participants, personnel, and outcome assessors); incomplete outcome data; selective outcome reporting; and other sources of bias. We categorized these judgments as low, high or unclear risk of bias.

For sequence generation, allocation concealment and blinding, we quoted the method as described in the trial in the Characteristics of included studies tables. For blinding, we stated the blinding method and who was blinded separately for different outcomes. For incomplete outcome data, we assigned a judgement for different outcomes (for example, loss to follow-up at different time points).

We resolved disagreements by discussion or consultation. Where risk of bias was unclear, we attempted to contact the trial authors for clarification.

\section{Measures of treatment effect}

We presented dichotomous outcomes as risk ratios (RR), and continuous outcomes as mean differences or geometric mean ratios. All results are shown with a 95\% confidence interval $(\mathrm{Cl})$.

\section{Unit of analysis issues}

For trials including more than two comparison groups, we split and analysed as individual pair-wise comparisons. When conducting meta-analysis we ensured that participants and cases in the placebo group were not counted more than once, by dividing the placebo cases and participants evenly between the intervention groups.

\section{Dealing with missing data}

The primary analysis is a complete case analysis where the number of evaluable participants at each time point is used as the denominator.

\section{Assessment of heterogeneity}

We assessed heterogeneity by inspecting forest plots for overlapping Cls and outlying data. We applied the $\mathrm{Chi}^{2}$ test with a $P$ value $<0.10$ to indicate statistically significant heterogeneity, and the $\mathrm{I}^{2}$ statistic with a value of greater than $50 \%$ to indicate moderate heterogeneity.

\section{Assessment of reporting biases}

We planned to evaluate the possibility of publication bias by constructing funnel plots, but there were too few trials within each comparison to make this meaningful.

\section{Data synthesis}

We analysed the data in pair-wise comparisons using Review Manager (RevMan). We stratified the primary analysis by drug dose and the time point after treatment. Data were combined in meta-analyses using a fixed-effect model. If we detected moderate heterogeneity but still considered combination of the trials to be appropriate we used a random-effects model. We presented data which could not be presented in forest plots in tables (medians, means without measure of variance, ranges).

We assessed quality of evidence using the GRADE approach, and displayed the results in 'Summary of Findings' tables. The GRADE approach defines quality as a measure of 'our confidence in the effect estimates' and defines four levels of quality; high, moderate, low and very low. The evidence from RCTs is rated as 'high quality' but can be downgraded where there are major concerns about: 1) the risk of bias of the trials; 2) inconsistency between the trial results; 3 ) a mismatch between the question being asked and the trial setting, population, intervention or control; 4) the trial being underpowered; or 5) evidence of publication bias.

\section{Subgroup analysis and investigation of heterogeneity}

We planned to conduct the following subgroup analyses to explore the potential causes of heterogeneity. However, there were too few trials within each comparison to make this meaningful: patient age (children versus adults), intensity of infection, endemicity.

\section{Sensitivity analysis}

Data were insufficient to assess the robustness of results by sensitivity analyses to evaluate risk of bias components and the effects of missing data.

\section{RE S U L T S}

\section{Description of studies}

\section{Results of the search}

Following database searches, we identified 116 individual citations, and a further 40 potential studies after we checked trial abstracts. Following abstract screening, we assessed 71 full text articles for inclusion. Figure 1 shows the flow diagram of these trials. 
Figure 1. Study flow diagram

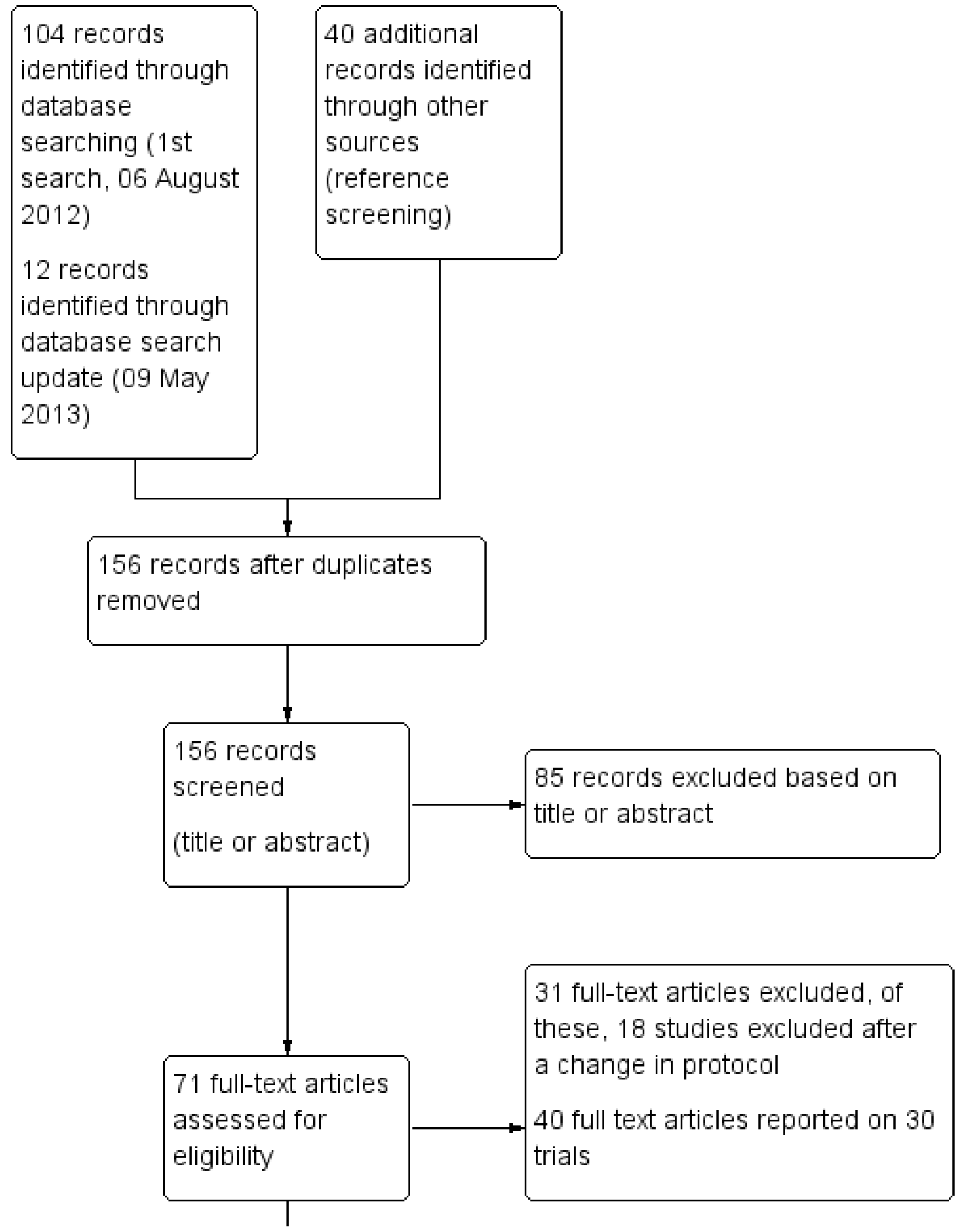


Figure 1. (Continued)

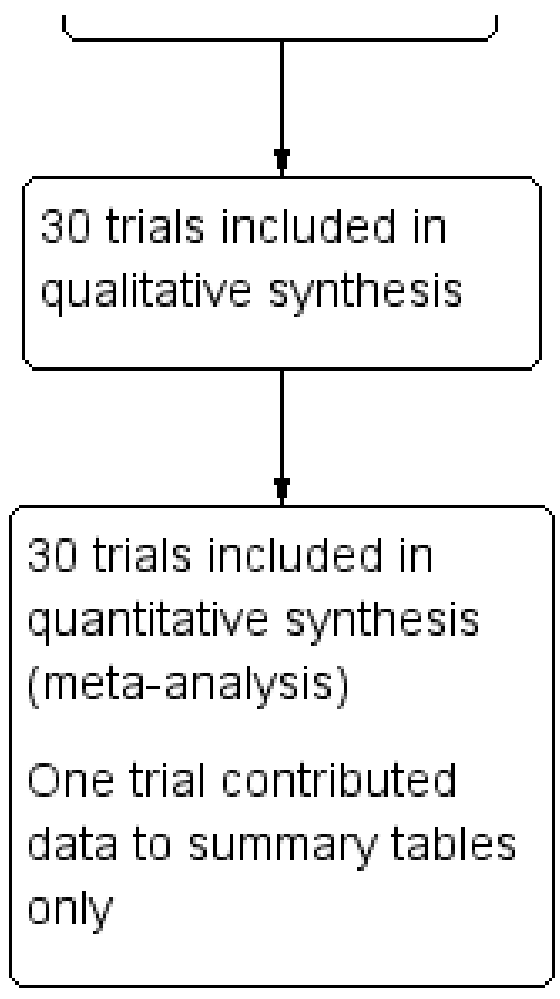

\section{Included studies}

We included 30 RCTs, enrolling 8965 participants, and reported in 39 publications. Twenty trials were over 20 years old, and only eight were published since the year 2000 .

\section{Settings}

All but one trial were conducted in sub Saharan Africa; 13 trials from East Africa: Somalia (one) Sudan (three), Tanzania (two), Kenya (six), Malawi (one); 13 trials from West Africa: Cameroon (two), Gabon (three), Niger (two), Mali (one), Nigeria (two), Cote d' Ivoire (one), Ghana (one), Gambia (one); and three trials from southern Africa: Zimbabwe (two), and Zambia (one). Most trials were based in rural settings, but two were conducted in peri-urban or semi-rural settings, three were from urban settings, and in one trial the setting was not described. The remaining trial was conducted in an urban setting in Saudi Arabia.

Twenty trials were based in schools and one in a college, seven in villages, farms or settlements, one in antenatal clinics and two in referral hospitals.

\section{Participants}

Twenty-four trials enrolled school-age children and young adults, although the exact age-range varied; age six to 20 years (16 trials), age five to 18 years (three trials), age two to 23 years (five trials). Two trials enrolled adults only, and four trials didn't clearly state the age range.
All trials diagnosed S. haematobium infection by detection of eggs or miracidia on urine microscopy. Sixteen trials reported egg counts as geometric mean egg counts, four trials as arithmetic mean egg counts, three trials reported both. One study reported geometric mean miracidial counts. Six trials used ranges or medians.

\section{Interventions}

Eight trials compared praziquantel with placebo, and 14 trials published between 1981 and 2009 compared different doses or regimens of praziquantel.

Five trials compared metrifonate with placebo, and seven trials published between 1983 and 1990 directly compared the efficacy of praziquantel and metrifonate.

More recently, three trials published between 2001 and 2009 evaluated artesunate as single agent or in combination with praziquantel, and two trials published in 2009 and 2011 evaluated mefloquine.

\section{Excluded studies}

We excluded 65 studies for the reasons given in the 'Characteristics of excluded studies' table.

\section{Risk of bias in included studies}

Many trials lacked adequate descriptions of methods to allow judgements on risk of bias, and so have been classified as unclear (see Figure 2). 
Figure 2. Risk of bias summary: review authors' judgements about each risk of bias item for each included trial.

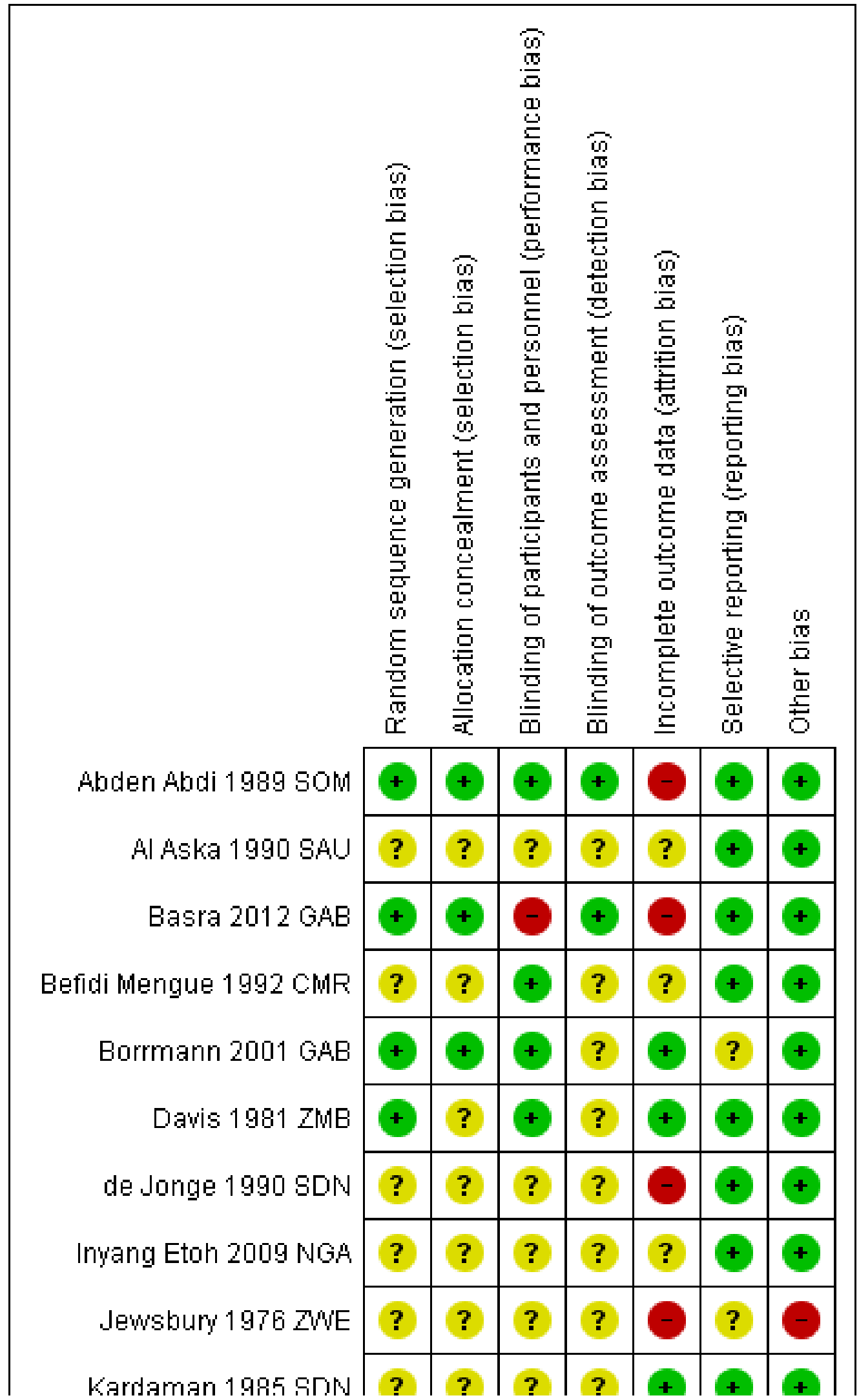


Figure 2. (Continued)

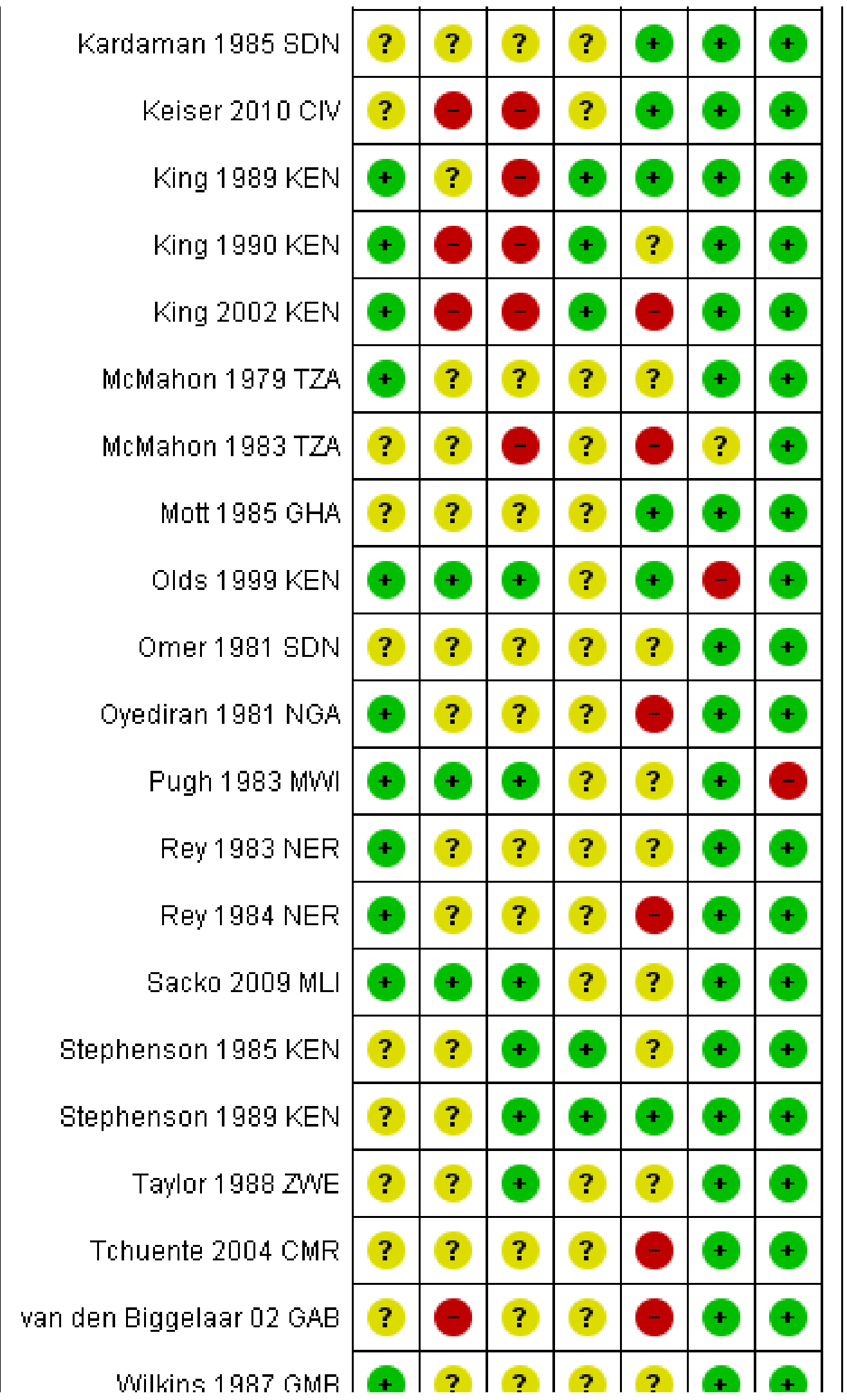


Figure 2. (Continued)

\section{\begin{tabular}{|l|l|l|l|l|l|l|l|}
\hline Wilkins 1987 GMB & $?$ & $?$ & $?$ & $?$ & $?$ & + & + \\
\hline
\end{tabular}}

\section{Allocation}

Fourteen trials adequately described a random method of sequence generation, but only six described a method of allocation concealment and could be considered at low risk of selection bias (Abden Abdi 1989 SOM; Basra 2012 GAB; Borrmann 2001 GAB; Olds 1999 KEN; Pugh 1983 MWI; Sacko 2009 MLI).

\section{Blinding}

Ten trials reported adequate attempts to blind participants and trial staff to treatment allocation, six trials were unblinded and blinding was unclear in the remaining trials. Seven trials reported adequate blinding of outcome assessors.

\section{Incomplete outcome data}

Many trials had high levels of attrition, particularly at later time points. When trials presented cure or failure rates as percentages, we were unable to assess attrition. We considered the risk of attrition bias to be unclear in 13 trials and high in nine trials.

\section{Selective reporting}

We found evidence of reporting bias in one trial, as trial authors did not present pre-specified outcomes. In three trials, selective reporting was at unclear risk of bias.

\section{Other potential sources of bias}

Trial authors reported baseline imbalances in two trials, which we identified as sources of other bias.

The trials were mostly funded by funds, trusts or international agencies (see Characteristics of included studies tables). Eight trials did not declare funding, four received drug donations and only two trials declared funding by pharmaceutical companies (both Dafra Pharma).

\section{Effects of interventions}

See: Summary of findings for the main comparison Praziquantel $40 \mathrm{mg} / \mathrm{kg}$ versus placebo for treating urinary schistosomiasis; Summary of findings 2 Praziquantel $40 \mathrm{mg} / \mathrm{kg}$ single dose versus $30 \mathrm{mg} / \mathrm{kg}$ single dose; Summary of findings 3 Praziquantel 40 $\mathrm{mg} / \mathrm{kg}$ multiple doses versus single dose; Summary of findings 4 Metrifonate $3 \times 7.5 \mathrm{mg} / \mathrm{kg}$ given two weeks apart versus placebo; Summary of findings $\mathbf{5}$ Artesunate versus placebo; Summary of findings 6 Praziquantel and artesunate versus praziquantel

\section{Section A: Praziquantel}

\section{Praziquantel $40 \mathrm{mg} / \mathrm{kg}$ single dose versus placebo (comparison 1)}

On average, a single $40 \mathrm{mg} / \mathrm{kg}$ dose of praziquantel reduces the proportion of people still excreting eggs at one to two months after treatment by around 60\% compared to placebo, and reduces the mean number of eggs excreted by over $95 \%$.
Eight trials compared a single $40 \mathrm{mg} / \mathrm{kg}$ dose of praziquantel with placebo or no treatment in schoolchildren in sub-Saharan Africa. We have listed the definitions of parasitological failure in Table 2.

\section{Parasitological failure}

Praziquantel $40 \mathrm{mg} / \mathrm{kg}$ as a single dose reduced parasitological treatment failure by around $60 \%$ at one to two months compared to placebo (RR $0.42,95 \% \mathrm{Cl} 0.29$ to $0.59 ; 864$ participants, seven trials, Analysis 1.1). The absolute level of treatment failure with praziquantel ranged from $16.6 \%$ (McMahon 1979 TZA) to $77.5 \%$ (de Jonge 1990 SDN). Treatment failure with placebo was greater than $80 \%$ in all seven trials and over $90 \%$ in four trials.

Four trials reported follow-up beyond two months (Analysis 1.1). Failure rate increased over time in two trials, as might be expected in areas of schistosomiasis transmission as people become reinfected (McMahon 1979 TZA; Pugh 1983 MWI). However, treatment outcomes improved in Taylor 1988 ZWE over time, with moderate reductions in treatment failure at one month and three months and a $70 \%$ reduction at six months. The trial authors stated that this improvement might have been due to excretion of remaining eggs from the urinary tract over time.

The fourth trial, de Jonge 1990 SDN, found no difference in treatment failure between praziquantel and placebo at any time point. The trial authors used a more sensitive diagnostic method (three urine samples, filtration of the whole volume up to $350 \mathrm{~mL}$ when the $10 \mathrm{~mL}$ urine sample contained fewer than 10 eggs) and a strict definition of cure (no excretion of eggs, no viability testing of eggs). This may explain the high failure rates observed despite high percent egg reductions comparable to other trials.

Stephenson 1989 KEN reported treatment failure at eight months, its only time point. A single dose of praziquantel reduced treatment failure by $86 \%$ compared to placebo (RR $0.14,95 \% \mathrm{Cl} 0.08$ to 0.22 ; 209 participants, one trial, Analysis 1.1).

Six trials reported parasitological failure stratified by intensity of infection; the categorisation of strata varied between trials (642 participants, see Appendix 2). At the first follow-up at four to six weeks, three out of four trials had a tendency to higher failure in participants with higher infection intensity. The pattern attenuated at later time points.

\section{Percent egg reduction}

Seven trials reported mean urine egg counts per $10 \mathrm{~mL}$ urine at baseline, and at one to two months after a single dose of praziquantel $40 \mathrm{mg} / \mathrm{kg}$ or placebo (867 participants, seven trials, see Table 3), although we were only able to reliably interpret this data for six trials (678 participants).

The mean egg count was reduced by more than $95 \%$ at one to two months following praziquantel in five trials, and by $75 \%$ in one trial. In the placebo groups the change in mean egg count ranged from a $53 \%$ decrease to a $115 \%$ increase. 
Percent egg reduction in the praziquantel group remained high $(>95 \%)$ in all three trials reporting at three months, and in all four trials at six months. Percent egg reduction was variable in the placebo group, ranging from $26 \%$ increase to $54 \%$ reduction at three months and from $5 \%$ to $64 \%$ reduction at six months (see Table 4). One additional trial, Stephenson 1989 KEN, reported percent egg reduction at eight months as its only time point (209 participants, see Table 4). Percent egg reduction after praziquantel was $99 \%$ compared to $5 \%$ with placebo.

Five trials reported percent egg reduction stratified by intensity of infection (764 participants, Appendix 2). At four to six weeks, all trials reported percent egg reductions over $90 \%$ across the strata. Percent egg reduction as a relative measure was at least as high in heavy infections as in mild infections, but post-treatment egg counts as an absolute measure tended to be higher in people with high intensity infections. This pattern persisted at later time points.

\section{Clinical resolution}

At eight weeks the proportion of patients with persistent haematuria (defined as $>5$ erythrocytes $/ \mathrm{mL}$ ) was lower in those given praziquantel than placebo in one small trial which reported this ( $\mathrm{RR} 0.53,95 \% \mathrm{Cl} 0.33$ to $0.84 ; 119$ participants, one trial, Analysis 1.2). There were substantial reductions in the mean number of erythrocytes in the urine in three trials at one to two months, but we could not combine these data in a meta-analysis (357 participants, three trials, see Appendix 3).

Proteinuria was reduced by $65 \%$ to $84 \%$ at one to two months after praziquantel compared to increases in the placebo groups (238 participants, two trials, see Appendix 3).

Two trials reported mean haemoglobin at baseline and at six to eight months after treatment with no difference between groups (mean difference $-0.08,95 \% \mathrm{Cl}-0.24$ to $0.09 ; 727$ participants, two trials, Analysis 1.3).

Three trials measured a variety of growth parameters (Befidi Mengue 1992 CMR; Olds 1999 KEN; Stephenson 1989 KEN). Two trials reported little or no effect on the outcomes measured (Befidi Mengue 1992 CMR; Olds 1999 KEN). The third trial (Stephenson 1989 KEN) reports 14 measures, some of which are reported as statistically significant, but all appear to be of no or only borderline clinical importance (see Appendix 4). Most notably, there is a reported increase in children's physical fitness as measured by the Harvard Step test. The difference in mean improvement between groups was $6.8 \%$ at five weeks (mean end scores $81.2 \%$ praziquantel versus $75.5 \%$ placebo). Scores between $68 \%$ and $82 \%$ are considered average. Children that took praziquantel also gained $1.2 \mathrm{~kg}$ more weight than those in the control group, however baseline differences between groups were of a similar magnitude to this effect.

\section{Adverse events}

Of nine trials, six (with 1286 participants) commented on adverse events. Only four described the methods used for data collection, but rarely reported them in detail (see Appendix 5). Adverse events were usually monitored in the first days after medication. Only two trials actually reported numbers of adverse events, and only abdominal pain was reported by both trials. The absolute number of adverse events was low and none were more common with praziquantel than placebo (see Analysis 1.4). The other trials summarized narratively with comments such as "both treatments were well tolerated" (see Appendix 5).

\section{Praziquantel $40 \mathrm{mg} / \mathrm{kg}$ versus lower doses (comparison 2)}

Praziquantel doses of 20 to $40 \mathrm{mg} / \mathrm{kg}$ result in similar reductions in mean egg excretion, but $40 \mathrm{mg} / \mathrm{kg}$ is marginally superior at achieving cure.

Ten trials compared praziquantel $40 \mathrm{mg} / \mathrm{kg}$ with lower doses: $30 \mathrm{mg} / \mathrm{kg}$ (seven trials), $20 \mathrm{mg} / \mathrm{kg}$ (three trials), and $10 \mathrm{mg} /$ $\mathrm{kg}$ (three trials). All trials were conducted in sub-Saharan Africa in schoolchildren, apart from one trial, which recruited college students and army recruits.

Treatment with praziquantel $40 \mathrm{mg} / \mathrm{kg}$ had fewer treatment failures than lower doses when measured at four to six weeks after treatment (versus $30 \mathrm{mg} / \mathrm{kg}$; RR $0.76,95 \% \mathrm{Cl} 0.59$ to $0.99 ; 401$ participants, four trials, Analysis 2.1, versus $20 \mathrm{mg} / \mathrm{kg}$; RR 0.74, $95 \%$ $\mathrm{Cl} 0.59$ to 0.93 ; 338 participants, two trials, Analysis 2.1). However, there was no difference between $40 \mathrm{mg} / \mathrm{kg}$ and $30 \mathrm{mg} / \mathrm{kg}$ at two to three months (517 participants, five trials, Analysis 2.2), or six months after treatment (699 participants, six trials, Analysis 2.3).

In the five trials comparing praziquantel $40 \mathrm{mg} / \mathrm{kg}$ and $30 \mathrm{mg} / \mathrm{kg}$, the mean number of eggs excreted was reduced by greater than $90 \%$ with both doses and without significant differences between groups (495 participants, five trials, see Table 5).

In trials comparing $40 \mathrm{mg} / \mathrm{kg}$ and $20 \mathrm{mg} / \mathrm{kg}$, again the mean number of eggs excreted was reduced by more than $95 \%$ for both doses and differences in percent egg reduction appeared small (636 participants, four trials, see Appendix 2). Treatment with praziquantel $40 \mathrm{mg} / \mathrm{kg}$ appeared to result in greater percent egg reductions than $10 \mathrm{mg} / \mathrm{kg}$ (357 participants, three trials, see Appendix 2).

One small trial from Kenya (King 1989 KEN) reported similar numbers of participants with persistent haematuria or proteinuria at three months with praziquantel $40 \mathrm{mg} / \mathrm{kg}, 30 \mathrm{mg} / \mathrm{kg}$ and $20 \mathrm{mg} /$ $\mathrm{kg}$, but $40 \mathrm{mg} / \mathrm{kg}$ was superior to $10 \mathrm{mg} / \mathrm{kg}$ (haematuria at three months: RR $0.35,95 \% \mathrm{Cl} 0.21$ to $0.58,119$ participants, one trial, Analysis 2.4; proteinuria at three months: $\mathrm{RR} 0.25,95 \% \mathrm{Cl} 0.12$ to $0.51 ; 119$ participants, one trial, Analysis 2.5$)$. A larger trial by the same authors comparing $40 \mathrm{mg} / \mathrm{kg}$ and $20 \mathrm{mg} / \mathrm{kg}$ (King 2002 KEN) detected fewer participants with haematuria at six weeks following praziquantel $40 \mathrm{mg} / \mathrm{kg}$ (RR $0.63,95 \% \mathrm{Cl} 0.47$ to $0.86 ; 245$ participants, one trial, Analysis 2.6), and fewer participants with proteinuria (RR $0.66,95 \% \mathrm{Cl} 0.46$ to $0.96 ; 245$ participants, one trial, Analysis 2.7). These differences were still observed at nine months (haematuria: RR $0.59,95 \% \mathrm{Cl} 0.44$ to $0.78 ; 215$ participants, one trial, Analysis 2.8; proteinuria RR $0.67,95 \% \mathrm{Cl} 0.5$ to $0.9 ; 214$ participants, one trial, Analysis 2.9). King 2002 KEN also reported ultrasound findings (bladder thickening, bladder irregularity and hydronephrosis) before and after treatment with praziquantel 40 $\mathrm{mg} / \mathrm{kg}$ and $20 \mathrm{mg} / \mathrm{kg}$ respectively, but the results were inconclusive (264 participants, see Appendix 6).

Six of these trials did not comment on adverse events. Four trials described the methods of data collection, but often in insufficient detail; two out of four trials used active, prospective surveillance for adverse events (Appendix 5). Two trials stated for all treatment arms collectively that adverse events after praziquantel treatment were mild and transient. Two trials reported numbers of adverse 
events with no differences between groups (163 participants, Analysis 3.2).

\section{Praziquantel $40 \mathrm{mg} / \mathrm{kg}$ single dose versus split dose (comparison} 3)

Splitting the dose of praziquantel $40 \mathrm{mg} / \mathrm{kg}$ into two $20 \mathrm{mg} / \mathrm{kg}$ doses over 24 hours has not been shown to improve tolerability and may actually cause more vomiting and dizziness.

Three trials compared the single $40 \mathrm{mg} / \mathrm{kg}$ dose with a split dose regimen giving two doses of $20 \mathrm{mg} / \mathrm{kg}$ over 24 hours. There was no statistically significant difference in treatment failure at one month (RR $0.75,95 \% \mathrm{Cl} 0.51$ to $1.11 ; 374$ participants, three trials), three months (RR $0.74,95 \% \mathrm{Cl} 0.45$ to $1.2 ; 361$ participants, three trials), or six months (RR $0.83,95 \% \mathrm{Cl} 0.51$ to $1.35 ; 234$ participants, three trials, Analysis 3.1). Similarly percent egg reduction was over $90 \%$ for both groups (332 participants, three trials, see Appendix 2).

These trials enrolled 191 participants for a single dose of praziquantel $40 \mathrm{mg} / \mathrm{kg}$ and 195 participants for a split dose of 2 x $20 \mathrm{mg} / \mathrm{kg}$. All trials used active surveillance for adverse events (see Appendix 5). Adverse events were generally reported to be mild and transient. However one trial reports significantly more vomiting and dizziness with the split dose compared to the single dose (vomiting: RR $0.5,95 \% \mathrm{Cl} 0.29$ to 0.86 ; dizziness: RR $0.39,95 \%$ $\mathrm{Cl} 0.16$ to $0.94 ; 373$ participants, three trials, Analysis 3.2).

\section{Praziquantel $40 \mathrm{mg} / \mathrm{kg}$ single dose versus multiple doses (comparison 4 and 5)}

There are too few trials to determine the optimal frequency and timing of repeated praziquantel dosing.

Two trials compared the standard single dose of praziquantel $(40 \mathrm{mg} / \mathrm{kg}$ ) with two or three doses given at two or three week intervals, and found no statistically significant differences in parasitological failure (Analysis 4.1, Analysis 4.2), percentage egg reduction (Appendix 2), or clinical resolution (Appendix 3; Analysis 4.3).

One additional very small trial from a high transmission setting in Gabon (van den Biggelaar 02 GAB), compared praziquantel 40 mg/ kg every three months for two years to a single dose of praziquantel $40 \mathrm{mg} / \mathrm{kg}$ given at the beginning of the trial. At two years, patients who received only one dose of praziquantel had almost three times the risk of treatment failure compared to multiple doses (RR 2.71, 95\% Cl 1.47 to 5.00; 62 participants, one trial, Analysis 5.1). Percent egg reduction was $96 \%$ after multiple doses and $80 \%$ after a single dose of praziquantel at two years ( 90 participants, see Table $6)$. These effects were no longer apparent one year after the last praziquantel dose.

These trials did not report on adverse events.

\section{Section B: Metrifonate}

\section{Metrifonate single dose versus placebo (comparison 6)}

A single dose of metrifonate $10 \mathrm{mg} / \mathrm{kg}$ probably reduces egg excretion but is only marginally better than placebo at achieving cure.

Two trials compared a single dose of metrifonate to placebo, although one trial only reported outcomes at a single time point eight months after treatment (Stephenson 1989 KEN).
In the first trial (Pugh $1983 \mathrm{MWI}$ ), 80\% of those treated with metrifonate continued to excrete eggs one month after treatment which was only marginally better than placebo (RR $0.83,95 \%$ $\mathrm{Cl} 0.74$ to 0.94 ; 142 participants, one trial, Analysis 6.1), and no difference was seen at six months (RR $0.94,95 \% \mathrm{Cl} 0.87$ to $1.02 ; 102$ participants, one trial, Analysis 6.1).

In the second trial (Stephenson 1989 KEN), 61\% of those treated with metrifonate continued to excrete eggs eight months after treatment compared with almost $100 \%$ who received placebo (RR $0.63,95 \% \mathrm{Cl} 0.54$ to $0.73,210$ participants, one trial, Analysis 6.1). Egg excretion was also reduced by more than $90 \%$ eight months after treatment compared to just $5 \%$ with placebo (210 participants, see Appendix 2).

The second trial also reported mean haemoglobin at baseline and eight months (with no difference between groups, Analysis 6.2), and various measures of nutrition and growth (see Appendix 4). However, this trial had three arms and the nutritional measures are reported for the metrifonate and praziquantel groups combined. Consequently, we were unable to evaluate the effect of metrifonate. Trial authors did not report adverse events.

\section{Metrifonate multiple doses versus placebo (comparison 7)}

Subsequently trials evaluated multiple doses of metrifonate given two weeks apart, which improved the proportion of patients being cured.

Two trials evaluated three doses of metrifonate $7.5 \mathrm{mg} / \mathrm{kg}$ given two weeks apart (Jewsbury 1976 ZWE; Stephenson 1985 KEN), and reported much reduced treatment failures compared to placebo at 11 weeks (RR $0.41,95 \% \mathrm{Cl} 0.30$ to 0.56 ; 93 participants, one trial, Analysis 7.1 ) and six months respectively (RR $0.30,95 \% \mathrm{Cl} 0.24$ to $0.37 ; 400$ participants, one trial, Analysis 7.1).

A third small trial (de Jonge 1990 SDN) comparing two $10 \mathrm{mg} / \mathrm{kg}$ doses given two weeks apart with placebo found very low levels of cure and no difference compared to placebo at one month or five months (51 participants, one trial, Analysis 7.1). However, this is the same trial that found very high levels of treatment failure with praziquantel, which may be a result of the highly sensitive method used for detecting low level egg excretion and the strict definition of cure.

All three trials found substantial reductions in the number of eggs being excreted at their various time points $>90 \%$ reductions in all three trials, see Table 7).

Stephenson 1985 KEN also reported mean haemoglobin, with slightly higher values at six months after metrifonate compared to placebo (mean difference $0.3 \mathrm{G} / \mathrm{dL}, 95 \% \mathrm{Cl} 0.14$ to $0.46 ; 400$ participants, one trial, Analysis 7.2). The authors noted that hookworm endemicity was high, and metrifonate also has an effect on hookworm which could account for this finding.

None of the trials reported on adverse events.

\section{Direct comparisons of different metrifonate regimens (comparisons 8 and 9)}

In one trial, multiple doses of $10 \mathrm{mg} / \mathrm{kg}$ were superior to a single dose.

One three-arm trial directly compared a single dose of $10 \mathrm{mg} / \mathrm{kg}$ with two or three doses given two weeks apart. Parasitological 
failure at one month was $53 \%$ with a single dose, $40 \%$ with two doses, and $19 \%$ with three doses. The difference was statistically significant for three doses versus one dose (RR $0.36,95 \% \mathrm{Cl} 0.17$ to 0.77 ; 93 participants, one trial, Analysis 8.1), but not two doses versus one dose (RR $0.75,95 \% \mathrm{Cl} 0.5$ to $1.13 ; 112$ participants, one trial, Analysis 8.1). Results were similar at four months (Analysis 8.2).

The percent egg reduction was also improved from $37 \%$ after a single dose to $88 \%$ after three doses, although this was not maintained at the four months' follow-up (see Appendix 2). This trial did not report on adverse events.

One additional trial (Abden Abdi 1989 SOM) compared three doses of $7.5 \mathrm{mg} / \mathrm{kg}$ given two weeks apart with three doses of $5 \mathrm{mg} / \mathrm{kg}$ given in one day. The trial detected no difference for parasitological failure at one month, three months or six months (201 participants, one trial, Analysis 9.1). Egg reduction at one month was above $90 \%$ after both metrifonate doses and was sustained (>90\%) at two, three and six months (201 participants, see Appendix 2). This trial recorded adverse events by active surveillance (Appendix 5). It did not detect a significant difference for any of the symptoms between treatment groups (201 participants, one trial, Analysis 9.2) The adverse events were mild and transient. Headache and abdominal pain were most common.

\section{Section C: Praziquantel versus metrifonate}

\section{Praziquantel $40 \mathrm{mg} / \mathrm{kg}$ single dose versus metrifonate $10 \mathrm{mg} / \mathrm{kg}$ single dose (comparison 10)}

Single dose praziquantel $40 \mathrm{mg} / \mathrm{kg}$ was more effective than single dose metrifonate $10 \mathrm{mg} / \mathrm{kg}$ in curing patients and reducing egg excretion.

Three trials compared the standard dose of praziquantel $40 \mathrm{mg} / \mathrm{kg}$ with a single dose of metrifonate $10 \mathrm{mg} / \mathrm{kg}$, although one trial only reported outcomes at eight months after treatment (Stephenson 1989 KEN).

In the first trial (Pugh $1983 \mathrm{MWI}$ ), parasitological failure at one month was halved with praziquantel $40 \mathrm{mg} / \mathrm{kg}$ compared to metrifonate $10 \mathrm{mg} / \mathrm{kg}$ ( $\mathrm{RR} 0.46,95 \% \mathrm{Cl} 0.34$ to $0.61 ; 183$ participants, one trial, Analysis 10.1). Treatment failure increased in both groups over the following five months which the authors suspect was due to egg excretion by maturing worms, as transmission and reinfection were low in the trial setting (Analysis 10.1). The second trial (Wilkins $1987 \mathrm{GMB}$ ), also found praziquantel to be superior to metrifonate at two to three months as its only time point (RR 0.45 , $95 \% \mathrm{Cl} 0.27$ to $0.75 ; 72$ participants, one trial, Analysis 10.1 ).

The third trial (Stephenson 1989 KEN), found substantial reductions in both treatment failure ( $\mathrm{RR} 0.21,95 \% \mathrm{Cl} 0.13$ to 0.36 ; 208 participants, one trial, Analysis 10.1) and egg excretion (see Appendix 2), with praziquantel compared to metrifonate. Haemoglobin levels measured in this trial were higher in the praziquantel treatment arm both at baseline and at follow-up (208 participants, one trial, Analysis 10.2). The trial did not detect a difference in growth parameters between groups but does not report them separately (see Appendix 4).

\section{Praziquantel $40 \mathrm{mg} / \mathrm{kg}$ single dose versus multiple doses of metrifonate $10 \mathrm{mg} / \mathrm{kg}$}

Two small trials found no difference in parasitological treatment failure or egg excretion between single dose praziquantel $40 \mathrm{mg} / \mathrm{kg}$ and two or three doses of metrifonate $10 \mathrm{mg} / \mathrm{kg}$.

Two small trials compared praziquantel $40 \mathrm{mg} / \mathrm{kg}$ single dose to two and three doses of metrifonate $10 \mathrm{mg} / \mathrm{kg}$ given two weeks apart. The trials detected no difference in parasitological treatment failure at different time points and with different metrifonate regimens. However, in one trial both drugs performed poorly (de Jonge 1990 SDN), and in one trial both performed well (Al Aska 1990 SAU) (see Analysis 10.3). The trial where both drugs performed poorly for parasitological failure has been discussed above and this is likely to be due to the very sensitive method for detecting eggs. In this trial, both drugs reduced mean egg excretion by over $98 \%$ at one month and five months (see Appendix 2), and a decrease in haematuria by over $90 \%$ at one month. Reduction in proteinuria was almost $80 \%$ in both groups (see Appendix 3 ).

Only Al Aska 1990 SAU reported adverse events; dizziness was more common after praziquantel (RR $2.9,95 \% \mathrm{Cl} 1.59$ to 5.3; 100 participants, one trial, Analysis 10.4$)$. Dizziness $(20 \%$ in the praziquantel group and $10 \%$ in the metrifonate group) and abdominal pain $(12 \%$ both in the praziquantel and metrifonate group) were the most common side effects (Appendix 5).

\section{Additional comparisons of praziquantel and metrifonate}

One small trial compared a single dose of praziquantel $30 \mathrm{mg} /$ $\mathrm{kg}$ to three doses of metrifonate $10 \mathrm{mg} / \mathrm{kg}$ given two weeks apart and found no difference in parasitological failure at two months, but a statistically significant difference in favour of praziquantel at four months (RR $0.24,95 \% \mathrm{Cl} 0.07$ to $0.8 ; 52$ participants, one trial, Analysis 10.5). Egg reduction at four months was above $98 \%$ in both treatment groups (Appendix 2). In this trial, abdominal pain was more common in the metrifonate group (RR $0.33,95 \% \mathrm{Cl} 0.12$ to 0.92; 60 participants, one trial, Analysis 10.6), while no difference was detected for the eight other clinically diagnosed symptoms reported.

One large population-based trial from Kenya compared praziquantel $40 \mathrm{mg} / \mathrm{kg}$ given once a year to metrifonate $10 \mathrm{mg} /$ $\mathrm{kg}$ given three times a year. After one year, this trial detected no difference in treatment failure, haematuria or proteinuria (1400 participants, one trial, Analysis 10.7), but mean egg excretion was reduced by over $80 \%$ in both groups at one year (Appendix 2). There continued to be no difference in parasitological failure at two years, but praziquantel was superior in the third year (RR $0.62,95 \% \mathrm{Cl}$ 0.42 to $0.93 ; 827$ participants one trial, Analysis 10.8). Ultrasound findings, recorded in a sub-sample of children, were inconclusive (373 participants, Appendix 6).

One further small trial compared a single dose of praziquantel $40 \mathrm{mg} / \mathrm{kg}$ with a combination of praziquantel $10 \mathrm{mg} / \mathrm{kg}$ and metrifonate $10 \mathrm{mg} / \mathrm{kg}$. At two to three months there was no difference in treatment failure (72 participants, one trial, Analysis 10.9). Percent egg reduction was $99.4 \%$ after praziquantel alone and $92.9 \%$ after the combination treatment (see Appendix 2).

None of the trials reported on adverse events. 


\section{Section D: Artesunate}

\section{Artesunate versus placebo (comparison 11)}

The two placebo controlled trials of artesunate had inconsistent results, and the single trial at low risk of bias found only a modest effect on egg excretion compared to placebo.

Two trials compared artesunate $4 \mathrm{mg} / \mathrm{kg}$ once daily for three days with placebo. The two trials had inconsistent results on parasitological failure, with one trial finding no difference between artesunate and placebo, and one finding lower treatment failures with artesunate at eight weeks ( 251 participants, two trials, Analysis 11.1). The trial finding an effect was at unclear risk of both selection and detection bias due to an inadequate description of trial methods (Inyang Etoh 2009 NGA).

Both trials found that artesunate reduced egg excretion compared to placebo (Table 8), but the percent reduction was low compared to that seen in placebo controlled trials of praziquantel (percent egg reductions of between $52 \%$ and $69 \%$ ).

The trial at unclear risk of bias also reported improved reductions in haematuria and proteinuria compared to placebo, while the trial at low risk of bias (Borrmann $2001 \mathrm{GAB}$ ) found no effect on proteinuria (see Appendix 3). No differences in adverse events were reported (see Appendix 5, Analysis 11.3).

\section{Praziquantel versus artesunate (comparison 12)}

The results of the three trials are inconsistent, with the single trial at low risk of bias finding only a modest reduction in egg excretion with artesunate.

Three trials (Borrmann 2001 GAB; Inyang Etoh 2009 NGA; Keiser $2010 \mathrm{CIV}$ ) compared artesunate $4 \mathrm{mg} / \mathrm{kg} / \mathrm{d}$ for three days with praziquantel $40 \mathrm{mg} / \mathrm{kg}$ single dose.

The three trials had mixed results. In two trials artesunate performed poorly, with parasitological treatment failures of over $70 \%$ at one month and two months respectively (Borrmann 2001 $\mathrm{GAB}$; Keiser $2010 \mathrm{CIV}$ ). In these trials praziquantel was clearly superior (Analysis 12.1). In the third trial (Inyang Etoh 2009 NGA), at unclear risk of bias due to inadequate description of trial methods, artesunate performed similarly to praziquantel with $28 \%$ treatment failures at two months (Analysis 12.1).

The percent egg reduction with artesunate varied across the three trials from $52 \%$ to $85 \%$ (see Appendix 2). In the single trial where both praziquantel and artesunate performed well at reducing treatment failures, both drugs had fairly modest effects on egg excretion (Inyang Etoh 2009 NGA).

Only the trial at unclear risk of bias (Inyang Etoh 2009 NGA) reported substantial effects of artesunate on haematuria and proteinuria (see Appendix 3). In the trial at low risk of bias (Borrmann 2001 GAB) praziquantel was clearly superior at reducing microhematuria (RR $0.43,95 \% \mathrm{Cl} 0.3$ to $0.62 ; 178$ participants, one trial, Analysis 12.2 ).

All trials reported on adverse events with no significant differences noted between groups (see Appendix 5, Analysis 12.3).
Praziquantel versus praziquantel plus artesunate (comparison 13)

The results of the two trials were inconsistent but the trial at low risk of bias found no benefit with adding artesunate to praziquantel.

Two of the trials comparing artesunate with praziquantel also had a treatment arm where patients received both drugs (Borrmann 2001 GAB; Inyang Etoh 2009 NGA). Again, in the trial at low risk of bias (Borrmann 2001 GAB) adding artesunate to praziquantel did not substantially reduce treatment failures or percent egg reduction at eight weeks compared to praziquantel alone, whereas in the trial at unclear risk of bias (Inyang Etoh 2009 NGA), adding artesunate improved outcomes (Analysis 13.1; Table 9; Appendix 2). No differences in adverse events were reported (see Appendix 5).

\section{Section E: Others}

\section{Mefloquine versus sulfadoxine-pyrimethamine (comparison 14)}

In a single trial comparing the use of mefloquine and sulfadoxinepyrimethamine as intermittent preventive treatment for malaria in pregnancy, a re-analysis of the small number of mothers infected with $S$. haematobium found more women were cured at one month after mefloquine compared to sulfadoxine-pyrimethamine (RR $0.57,95 \% \mathrm{Cl} 0.4$ to 0.83 ; 44 participants, one trial, Analysis 14.1), and an egg reduction of $80 \%$ four weeks after treatment and $98 \%$ ten weeks after treatment (see Appendix 2).

\section{Praziquantel versus mefloquine alone or mefloquine in combination with artesunate (comparison 15 and 16)}

A single small trial (Keiser 2010 CIV) reported lower treatment failures with praziquantel $40 \mathrm{mg} / \mathrm{kg}$ alone than with mefloquine $25 \mathrm{mg} / \mathrm{kg}$ (RR $0.15,95 \% \mathrm{Cl} 0.05$ to $0.43 ; 45$ participants, one trial, Analysis 15.1) or with mefloquine in combination with artesunate 4 $\mathrm{mg} / \mathrm{kg} / \mathrm{d}$ for three days (RR $0.23,95 \% \mathrm{Cl} 0.07$ to 0.74 ; 44 participants, one trial, Analysis 16.1). At four weeks, this trial reports a percent egg reduction of $74 \%$ at four weeks with mefloquine alone (19 participants), $96 \%$ with mefloquine and artesunate combined, and 97\% with praziquantel (Appendix 2).

Keiser 2010 CIV recorded adverse events by active, prospective surveillance. Adverse events were mild to moderate and common in all groups. There were no statistically significant differences in any individual adverse event (Appendix 5).

\section{Praziquantel versus praziquantel and albendazole (comparison 17)}

One trial (Olds 1999 KEN) compared a single dose of praziquantel $40 \mathrm{mg} / \mathrm{kg}$ with a combination of single dose praziquantel $40 \mathrm{mg} / \mathrm{kg}$ plus albendazole $400 \mathrm{mg}$ at day 45 (RR $0.9,95 \% \mathrm{Cl} 0.62$ to $1.3 ; 193$ participants, one trial, Analysis 17.1). The authors concluded that albendazole does not influence the effect of praziquantel.

Adverse events were monitored by active, prospective surveillance and described as mild and transient. Diarrhoea, headache and abdominal pain were observed most frequently, but adverse events were reported for participants treated for S. haematobium and $S$. mansoni together (Appendix 5).

\section{DISCUSSION}

For a summary of the main results of the review and GRADE assessment of the quality of evidence see: Summary of findings for 
the main comparison; Summary of findings table 2; Summary of findings 2; Summary of findings 3; Summary of findings 4; Summary of findings 5; and Summary of findings 6 .

\section{Summary of main results}

On average, a single $40 \mathrm{mg} / \mathrm{kg}$ dose of praziquantel reduced the proportion of people still excreting $S$. haematobium eggs in their urine by around $60 \%$ compared to placebo at one to two months after treatment (high quality evidence), and reduced the mean number of schistosome eggs in the urine by over $95 \%$ in five out of six trials (high quality evidence). Splitting praziquantel $40 \mathrm{mg} / \mathrm{kg}$ into two doses over 12 hours probably has no benefits over a single dose.

Two small trials compared a single $40 \mathrm{mg} / \mathrm{kg}$ dose of praziquantel with two or three doses of $10 \mathrm{mg} / \mathrm{kg}$ metrifonate and found no differences in cure. In one trial both drugs performed badly and in one trial both performed well.

Three trials evaluated the antimalarial artesunate, and two trials evaluated mefloquine, with inconsistent results.

\section{Overall completeness and applicability of evidence}

The WHO currently recommend that schistosomiasis is treated with a single dose of praziquantel of at least $40 \mathrm{mg} / \mathrm{kg}$ (WHO 2006). In this review we found no trials evaluating doses higher than $40 \mathrm{mg}$ in urinary schistosomiasis, but doses of $40 \mathrm{mg} / \mathrm{kg}$ or even $30 \mathrm{mg} / \mathrm{kg}$ are effective at reducing egg excretion and achieving cure.

Of all the drugs that have been evaluated for treating urinary schistosomiasis, praziquantel has by far the strongest evidence base. It has been evaluated across a wide range of endemic countries, and most trials were conducted in children who bear the highest burden of disease. However, few trials included children younger than five years of age, and Stothard 2013 suggested that higher doses of praziquantel might be required for this group. We would have liked to explore this possibility through an analysis stratified by age, but the data did not allow this and no firm conclusions can be made. In addition, most trials concentrated on parasitological efficacy, and few reported clinical outcomes such as improvement in haematuria or anaemia. Data on resolution of long-term morbidity after treatment, as nutritional outcomes and sonographic findings are very rare, and follow-up is limited to less than one year.

The absolute proportion of people cured by praziquantel varied between trials while percent egg reduction was relatively homogenous. This may be explained by low sensitivity and negative predictive value of the diagnostic test, compounded with the fact that egg yield varies during the day and with physical activity. This means that patients with few eggs in their urine may be variably declared as positive or negative in different settings. The proportional reduction in the mean egg counts from before to after treatment is less prone to this error. It also appears that some trials based post-treatment egg reduction on the whole trial population (including cured patients with zero egg counts), while other trials based the post-treatment calculations on those patients still excreting eggs. We were unable to combine egg reduction values in meta-analysis, and assess statistical significance, due to the poor reporting of standard deviations and methods for calculating the mean (Table 2).
None of the included trials suggested drug resistance as a possible cause of high parasitological failure, or of recurrent schistosomiasis over prolonged follow-up. In high transmission areas two mechanisms could explain rising parasitological failure over time: maturation of immature worms (which escape the action of praziquantel) to egg producing adults, and reinfection.

Previously the WHO also recommended metrifonate at $7.5 \mathrm{mg} / \mathrm{kg}$ for three doses (given two weeks apart), but this drug is now largely unavailable (Danso-Appiah 2008). We found some evidence that repeated doses of metrifonate had reasonable antischistosomal effects but we found no trials directly comparing this dose with the standard dose of praziquantel. Combining praziquantel with metrifonate is one possible strategy for improving parasitological cure as they attack S. haematobium by different mechanisms (Utzinger 2004). However, we only found one small trial evaluating a combination approach and this used a low dose of praziquantel rather than the standard $40 \mathrm{mg} / \mathrm{kg}$ (Wilkins $1987 \mathrm{GMB}$ ).

Antimalarials (such as artesunate and mefloquine) given alone or in combination with praziquantel are another potential future treatment option, but the current evidence base is limited to a few trials with inconsistent results. As many locations in subSaharan Africa are co-endemic for schistosomiasis and malaria, there are also concerns about development of Plasmodium parasite resistance to artemisinins, especially as they would be used in a single dose and without a companion antimalarial drug (Utzinger 2004). Any change in policy would need to fully consider this potential public health harm.

\section{Quality of the evidence}

We used the GRADE approach to assess the quality for the evidence.

We consider the evidence for substantial benefits with praziquantel compared to placebo to be of high quality, meaning we have confidence in this result. Many of the included trials are old, but reassuringly the findings of the most recent trial conducted in $2005 / 2006$ are consistent with the older studies.

However, we consider most of the evidence for other comparisons in this review to be of low or even very low quality. Most of the trials evaluating metrifonate are old and precede guidelines on transparent reporting of clinical trials. As such, many trials lacked adequate descriptions of methods to allow judgements on risk of bias, and so risk of bias has been classified as unclear. Trials were also generally small and underpowered to reliably detect or exclude effects.

Of the three trials reporting on the antischistosomal effects of artesunate, only one was at low risk of bias and this trial found little effect with artesunate compared to placebo (Borrmann $2001 \mathrm{GAB}$ ). Although the metanalysis suggests artesunate may improve cure when added to praziquantel, this evidence was of low quality due to inconsistency between trials, and the single trial showing a large effect being at unclear risk of bias for all domains.

\section{Potential biases in the review process}

Our information specialist followed a detailed, reproducible search strategy, and we searched reference lists of included trials. However, some trials might not be available online, and therefore an electronic search will not identify them. 
In many cases, clarification of information with authors was not possible as no contact e-mail addresses were available as the trials were very old.

\section{Agreements and disagreements with other studies or reviews}

Two recent systematic reviews evaluated the use of artemisinins in treating urinary schistosomiasis (Liu 2011; Pérez del Villar 2012), and both concluded that the combination of artesunate plus praziquantel is superior to praziquantel alone, While we find some evidence to support this we conclude that this evidence is only of low quality and encourage further high quality and adequately powered trials before any change in treatment policy. Of note, the trial at lowest risk of bias (Borrmann 2001 GAB), found no significant difference in cure between artesunate alone and placebo, or between praziquantel plus artesunate and praziquantel alone.

One further systematic review evaluated single or repeated doses of praziquantel, and found no evidence of benefit with repeated dosing compared to a single dose in people with S. haematobium infection (King 2011). We would agree that repeating doses two or three weeks apart does not seem to provide benefit over a single dose based on two trials with 686 participants. However, repeating doses at three monthly intervals over two years did seem to provide some additional benefits in a single small trial and further trials could evaluate this.

\section{AUTHORS' CONCLUSIONS}

\section{Implications for practice}

Praziquantel is the most studied drug for treating urinary schistosomiasis and has the strongest evidence base. Although there is some evidence that $30 \mathrm{mg} / \mathrm{kg}$ may be sufficient, operationally this would prove difficult as $40 \mathrm{mg} / \mathrm{kg}$ is used to treat people with intestinal schistosomiasis, and the two diseases often overlap.

\section{Implications for research}

Potential strategies to improve future treatments for schistosomiasis include the combination of praziquantel with metrifonate, or with antimalarials with antischistosomal properties such as artesunate and mefloquine. Evaluation of these combinations requires rigorous. adequately powered trials using standardized outcome measures. It is both important and urgent that these parameters be agreed upon and applied. Trial protocols with standardised diagnostic methods, time points of follow-up and efficacy outcomes would enable us to combine trials in metaanalysis and to reduce heterogeneity between trials.

\section{ACKN O WLEDGEMENTS}

We would like to thank the authors of the previous version of this review Anthony Danso-Appiah, Jürg Utzinger, and Jianping Liu, who stood down for this update.

We thank the trial authors for their research, which enabled us to conduct a systematic review and particularly trial authors that responded to our requests for further information. We acknowledge Paul Garner for his expertise, experience and encouragement; Anne Marie Stephani, whose ready technical assistance with Review Manager (RevMan) was most helpful; and to Vittoria Lutje for her approachability and support. The editorial base of the Cochrane Infectious Diseases Group is funded by the UK Department for International Development for the benefit of developing countries. 


\section{R E F E R E N C E S}

\section{References to studies included in this review}

Abden Abdi 1989 SOM \{published data only\}

* Aden-Abdi Y, Gustafsson LL, Elmi SA. A simplified dosage schedule of metrifonate in the treatment of Schistosoma haematobium infection in Somalia. European Journal of Clinical Pharmacology 1987;32(5):437-41.

\section{Al Aska 1990 SAU \{published data only\}}

Al-Aska AK, Al-Mofleh IA, Al-Rashed R, Hafez MA, Al-Nozha M, Abu-Aisha $\mathrm{H}$, et al. Praziquantel, oxamniquine, and metrifonate in the treatment of schistosomiasis in Riyadh. Annals of Saudi Medicine 1990;10(3):296-8.

\section{Basra 2012 GAB \{published data only\}}

* Basra A, Mombo-Ngoma G, Melser MC, Diop DA, Würbel H, Mackanga JR, et al. Efficacy of mefloquine intermittent preventive treatment in pregnancy against Schistosoma haematobium infection in Gabon: a nested randomized controlled assessor-blinded clinical trial. Clinical Infectious Diseases 2012;56(6):e68-75.

\section{Befidi Mengue 1992 CMR \{published data only\}}

* Befidi-Mengue R N, Ratard R C, D'Alessandro A, Rice J, BefidiMengue R, Kouemeni L E, et al. The impact of Schistosoma haematobium infection and of praziquantel treatment on the growth of primary school children in Bertoua, Cameroon. Journal of Tropical Medicine and Hygiene 1992;95(6):404-9.

Befidi-Mengue RN, Ratard RC, Beltran G, D'Alessandro A, Rice J, Befidi-Mengue R, et al. Impact of Schistosoma haematobium infection and of praziquantel treatment on anaemia of primary school children in Bertoua, Cameroon. Journal of Tropical Medicine and Hygiene 1993;96(4):225-30.

\section{Borrmann 2001 GAB \{published data only\}}

Borrmann S, Szlezak N, Faucher JF, Matsiegui PB, Neubauer R, Binder RK, et al. Artesunate and praziquantel for the treatment of Schistosoma haematobium infections: a double-blind, randomized, placebo-controlled study. Journal of Infectious Diseases 2001;184(10):1363-6.

\section{Davis 1981 ZMB $\{$ published data only\}}

Davis A, Biles JE, Ulrich AM, Dixon H. Tolerance and efficacy of praziquantel in phase IIA and IIB therapeutic trials in Zambian patients. Arzneimittel-Forschung 1981;31(3a):568-74.

\section{de Jonge 1990 SDN $\{$ published data only\}}

Doehring E, Ehrich JH, Vester U, Feldmeier H, Poggensee U, Brodehl J. Proteinuria, hematuria, and leukocyturia in children with mixed urinary and intestinal schistosomiasis. Kidney International 1985;28(3):520-5.

Doehring E, Poggensee U, Feldmeier $\mathrm{H}$. The effect of metrifonate in mixed Schistosoma haematobium and Schistosoma mansoni infections in humans. American Journal of Tropical Medicine and Hygiene 1986;35(2):323-9.

* de Jonge N, Schommer G, Feldmeier H, Krijger FW, Dafalla AA, Bienzle $\mathrm{U}$, et al. Mixed Schistosoma haematobium and $\mathrm{S}$. mansoni infection: effect of different treatments on the serum level of circulating anodic antigen (CAA). Acta Tropica 1990;48(1):25-35.

\section{Inyang Etoh 2009 NGA \{published data only\}}

Inyang-Etoh PC, Ejezie GC, Useh MF, Inyang-Etoh EC. Efficacy of a combination of praziquantel and artesunate in the treatment of urinary schistosomiasis in Nigeria. Transactions of the Royal Society of Tropical Medicine and Hygiene 2009;103(1):38-44.

\section{Jewsbury 1976 ZWE \{published data only\}}

Jewsbury JM, Cooke MJ. Prophylaxis of schistosomiasis - field trial of metrifonate for the prevention of human infection. Annals of Tropical Medicine and Parasitology 1976;70(3):361-3.

\section{Kardaman 1985 SDN \{published data only\}}

Kardaman MW, Fenwick A, el Igail AB, el Tayeb M, Daffalla AA, Dixon HG. Treatment with praziquantel of schoolchildren with concurrent Schistosoma mansoni and S. haematobium infections in Gezira, Sudan. Journal of Tropical Medicine and Hygiene 1985;88(2):105-9.

\section{Keiser 2010 CIV \{published data only\}}

Keiser J, N'Guessan NA, Adoubryn KD, Silué KD, Vounatsou P, Hatz C, et al. Efficacy and safety of mefloquine, artesunate, mefloquine-artesunate, and praziquantel against Schistosoma haematobium: randomized, exploratory open-label trial. Clinical Infectious Diseases 2010;50(9):1205-13.

King 1989 KEN \{published data only\} King CH, Wiper DW 3rd, De Stigter KV, Peters PA, Koech D, Ouma JH, et al. Dose-finding study for praziquantel therapy of Schistosoma haematobium in Coast Province, Kenya. American Journal of Tropical Medicine and Hygiene 1989;40(5):507-13.

\section{King 1990 KEN \{published data only\}}

King CH, Lombardi G, Lombardi C, Greenblatt R, Hodder S, Kinyanjui $\mathrm{H}$, et al. Chemotherapy based control of schistosomiasis haematobia. I. Metrifonate versus praziquantel in control of intensity and prevalence of infection. American Journal of Tropical Medicine and Hygiene 1988;39(3):295-305.

* King CH, Lombardi G, Lombardi C, Greenblatt R, Hodder S, Kinyanjui $\mathrm{H}$, et al. Chemotherapy based control of schistosomiasis haematobia. II. Metrifonate vs. praziquantel in control of infection associated morbidity. American Journal of Tropical Medicine and Hygiene 1990;42(6):587-95.

King $\mathrm{CH}$, Muchiri E, Ouma JH, Koech D. Chemotherapy based control of schistosomiasis haematobia. IV. Impact of repeated annual chemotherapy on prevalence and intensity of Schistosoma haematobium infection in an endemic area of Kenya. American Journal of Tropical Medicine and Hygiene 1991;45(4):498-508.

\section{King 2002 KEN \{published data only\}}

King $\mathrm{CH}$, Muchiri EM, Mungai $\mathrm{P}$, Ouma JH, Kadzo H, Magak P, et al. Randomized comparison of low-dose versus standard-dose praziquantel therapy in treatment of urinary tract morbidity 
due to Schistosoma haematobium infection. American Journal of Tropical Medicine and Hygiene 2002;66(6):725-30.

McMahon 1979 TZA \{published data only\}

McMahon JE, Kolstrup N. Praziquantel: a new schistosomicide against Schistosoma haematobium. British Medical Journal 1979;2(6202):1396-9.

\section{McMahon 1983 TZA \{published data only\}}

McMahon JE. A comparative trial of praziquantel, metrifonate and niridazole against Schistosoma haematobium. Annals of Tropical Medicine and Parasitology 1983;77(2):139-42.

\section{Mott 1985 GHA \{published data only\}}

Mott KE, Dixon H, Osei-Tutu E, England EC, Davis A. Effect of praziquantel on hematuria and proteinuria in urinary schistosomiasis. American Journal of Tropical Medicine and Hygiene 1985;34(6):1119-26.

\section{Olds 1999 KEN $\{$ published data only\}}

Olds GR, King C, Hewlett J, Olveda R, Wu G, Ouma J, et al. Double-blind placebo-controlled study of concurrent administration of albendazole and praziquantel in schoolchildren with schistosomiasis and geohelminths. Journal of Infectious Diseases 1999;179(4):996-1003.

\section{Omer 1981 SDN \{published data only\}}

Omer AH. Praziquantel in the treatment of mixed S. haematobium and S. mansoni infections. ArzeneimittelForschung 1981;31(3a):605-8.

\section{Oyediran 1981 NGA \{published data only\}}

Oyediran AB, Kofie BA, Bammeke AO, Bamgboye EA. Clinical experience with praziquantel in the treatment of Nigerian patients infected with S. haematobium. Arzneimittel-Forschung 1981;31(3a):581-4

\section{Pugh 1983 MWI \{published data only\}}

Pugh RN, Teesdale $\mathrm{CH}$. Long-term efficacy of single-dose oral treatment in schistosomiasis haematobium. Transactions of the Royal Society of Tropical Medicine and Hygiene 1984;78(1):55-9.

* Pugh RN, Teesdale CH. Single dose oral treatment in urinary schistosomiasis: a double blind trial. British Medical Journal 1983;286(6363):429-32.

\section{Rey 1983 NER \{published data only\}}

Rey JL, Sellin B, Gazere O, Ott D, Reges M, Garrouty P. Comparison study of praziquantel efficiency $(30 \mathrm{mg} / \mathrm{kg}$ and 40 $\mathrm{mg} / \mathrm{kg}$ ) in a single dose and oltipraz (35 mg/ $/ \mathrm{kg}$ ) in two doses on Schistosoma haematobium in Niger [Comparaison au Niger de l' efficacite sur Schistosoma haematobium du Praziquantel (30 mg/kg et $40 \mathrm{mg} / \mathrm{kg}$ ) en une prise et de l' Oltipraz (35 $\mathrm{mg} / \mathrm{kg}$ ) en deux prises]. Medicine et Maladies Infectieuses 1983;13(6):328-31.

\section{Rey 1984 NER \{published data only\}}

Rey JL, Nouhou H, Sellin B. Comparison of three metrifonate dosages in mass chemotherapy of Schistosoma haematobium [Comparaison de trois posologies de Metrifonate en chimiotherapie de masse contre Schistosoma haematobium]. Médicine Tropicale 1984;44(1):57-60.

Sacko 2009 MLI \{published data only\}

Sacko M, Magnussen P, Traoré M, Landouré A, Doucouré A, Reimert CM, et al. The effect of single dose versus two doses of praziquantel on Schistosoma haematobium infection and pathology among school-aged children in Mali. Parasitology 2009;136(13):1851-7.

\section{Stephenson 1985 KEN \{published data only\}}

Stephenson LS, Latham MC, Kinoti SN, Oduori ML. Regression of splenomegaly and hepatomegaly in children treated for Schistosoma haematobium infection. American Journal of Tropical Medicine and Hygiene 1985;34(1):119-23.

Stephenson LS, Latham MC, Kurz KM, Kinoti SN, Oduori ML, Crompton DW. Relationships of Schistosoma haematobium, hookworm and malarial infections and metrifonate treatment to growth of Kenyan school children. American Journal of Tropical Medicine and Hygiene 1985;34(6):1109-18.

* Stephenson LS, Latham MC, Kurz KM, Kinoti SN, Oduori ML, Crompton DW. Relationships of Schistosoma haematobium, hookworm and malarial infections and metrifonate treatment to hemoglobin level in Kenyan school children. American Journal of Tropical Medicine and Hygiene 1985;34(3):519-28.

\section{Stephenson 1989 KEN \{published data only\}}

Latham MC, Stephenson LS, Kurz KM, Kinoti SN. Metrifonate or praziquantel treatment improves physical fitness and appetite of Kenyan schoolboys with Schistosoma haematobium and hookworm infections. American Journal of Tropical Medicine and Hygiene 1990;43(2):170-9.

* Stephenson LS, Kinoti SN, Latham MC, Kurz KM, Kyobe J. Single dose metrifonate or praziquantel treatment in Kenyan children. I. Effects on Schistosoma haematobium, hookworm, hemoglobin levels, splenomegaly, and hepatomegaly. American Journal of Tropical Medicine and Hygiene 1989;41(4):436-44.

Stephenson LS, Latham MC, Kurz KM, Kinoti SN. Single dose metrifonate or praziquantel treatment in Kenyan children. II. Effects on growth in relation to Schistosoma haematobium and hookworm egg counts. American Journal of Tropical Medicine and Hygiene 1989;41(4):445-53.

Taylor 1988 ZWE \{published data only\}

Taylor P, Murare HM, Manomano K. Efficacy of low doses of praziquantel for Schistosoma mansoni and S. haematobium. Journal of Tropical Medicine and Hygiene 1988;91(1):13-7.

Tchuente 2004 CMR \{published data only\}

Tchuenté LA, Shaw DJ, Polla L, Cioli D, Vercruysse J. Efficacy of praziquantel against Schistosoma haematobium infection in children. American Journal of Tropical Medicine and Hygiene 2004;71(6):778-82.

\section{van den Biggelaar 02 GAB \{published data only\}}

van den Biggelaar AH, Borrmann S, Kremsner P, Yazdanbakhsh M. Immune responses induced by repeated treatment do not result in protective immunity to Schistosoma 
haematobium: interleukin (IL)-5 and IL-10 responses. Journal of Infectious Diseases 2002;186(10):1474-82.

Wilkins 1987 GMB $\{$ published data only\}

Wilkins HA, Moore PJ. Comparative trials of regimens for the treatment of urinary schistosomiasis in The Gambia. Journal of Tropical Medicine and Hygiene 1987;90(2):83-92.

\section{References to studies excluded from this review}

\section{Aryeetey 1999 \{published data only\}}

Aryeetey ME, Aholu C, Wagatsuma Y, Bentil G, Nkrumah FK, Kojima S. Health education and community participation in the control of urinary schistosomiasis in Ghana. East African Medical Journal 1999;76(6):324-9.

\section{Ayoya 2007 \{published data only\}}

Ayoya MA. Effect of iron and/or multiple micronutrient supplementation added to praziquantel treatment of anemic Malian school children infected with schistosoma haematobium (Mali). Dissertation Abstracts International: Section B: The Sciences and Engineering 2007, issue 3-b.

\section{Bausch 1995 \{published data only\}}

Bausch D, Cline BL. The impact of control measures on urinary schistosomiasis in primary school children in northern Cameroon: a unique opportunity for controlled observations. American Journal of Tropical Medicine and Hygiene 1995;53(6):577-80.

\section{Beasley 1999 \{published data only\}}

Beasley NM, Tomkins AM, Hall A, Kihamia CM, Lorri W, Nduma B, et al. The impact of population level deworming on the haemoglobin levels of schoolchildren in Tanga, Tanzania. Tropical Medicine and International Health 1999;4(11):744-50.

Bejon 2008 \{published data only\}

Bejon P, Mwangi TW, Lowe B, Peshu N, Hill AV, Marsh K. Helminth infection and eosinophilia and the risk of Plasmodium falciparum malaria in 1- to 6-year-old children in a malaria endemic area. PLoS Neglected Tropical Diseases 2008;2(1):e164.

\section{Bhargava 2003 \{published data only\}}

* Bhargava A, Jukes M, Lambo J, Kihamia CM, Lorri W, Nokes C, et al. Anthelmintic treatment improves the hemoglobin and serum ferritin concentrations of Tanzanian schoolchildren. Food and Nutrition Bulletin 2003;24(4):332-42.

\section{Boulanger 2007 \{published data only\}}

Boulanger D, Dieng Y, Cisse B, Remoue F, Capuano F, Dieme JL, et al. Antischistosomal efficacy of artesunate combination therapies administered as curative treatments for malaria attacks. Transactions of the Royal Society of Tropical Medicine and Hygiene 2007;101(2):113-6.

\section{Burchard 1984 \{published data only\}}

Burchard GD, Kern P, Baltes R, Dietrich M. Comparative trial of oltipraz versus praziquantel in the treatment of urinary schistosomiasis in the Gabon. Tropenmedizin und Parasitologie 1984;35(2):91-4.

\section{Clarke 1969 \{published data only\}}

Clarke Vde V, Blair DM, Weber MC. Field trial of hycanthone (Etrenol Winthrop) in the treatment of urinary and intestinal bilharziasis. Central African Journal of Medicine 1969;15(1):1-6.

\section{Clarke 1973 \{published data only\}}

Clarke Vde V, Weber MC, Blair DM. Suppressive therapy in the control of bilharziasis: a comparative trial in African school children. Central African Journal of Medicine 1973;Sep:32-8.

Creasey 1986 \{published data only\}

Creasey AM, Taylor P, Thomas JE. Dosage trial of a combination of oxamniquine and praziquantel in the treatment of schistosomiasis in Zimbabwean schoolchildren. Central African Journal of Medicine 1986;32(7):165-7.

Danso-Appiah 2009 \{published data only\}

Danso-Appiah A, Garner P, Olliaro PL, Utzinger J. Treatment of urinary schistosomiasis: methodological issues and research needs identified through a Cochrane systematic review. Parasitology 2009;136(13):1837-49.

Davis 1966 \{published data only\}

Davis A. Field trials of ambilhar in the treatment of urinary bilharziasis in schoolchildren. Bulletin of the World Health Organization 1966;35(6):827-35.

Davis 1979 \{published data only\}

Davis A, Wegner DH. Multicentre trials of praziquantel in human schistosomiasis: design and techniques. Bulletin of the World Health Organisation 1979;57(5):767-71.

\section{De Clercq 2002 \{published data only\}}

De Clercq D, Vercruysse J, Kongs A, Verlé P, Dompnier JP, Faye PC. Efficacy of artesunate and praziquantel in Schistosoma haematobium infected schoolchildren. Acta Tropica 2002;82(1):61-6.

Druilhe 1981 \{published data only\} Druilhe P, Bourdillon F, Froment A, Kyelem J M. [Control of urinary schistosomiasis by 3 annual courses of metrifonate]. Annales de la Société belge de médecine tropicale 1981;61(1):99-109.

\section{el Hawey 1990 \{published data only\}}

el-Hawey AM, Massoud AM, el-Rakieby A, Rozeik MS, Nassar MO. Side effects of praziquantel in bilharzial children on a field level. Journal of the Egyptian Society of Parasitology 1990;20(2):599-605.

\section{el Tayeb 1988 \{published data only\}}

el Tayeb M, Daffalla AA, Kardaman MW, See R, Fenwick A. Praziquantel and oltipraz: the treatment of schoolchildren infected with Schistosoma mansoni and/or Schistosoma haematobium in Gezira, Sudan. Annals of Tropical Medicine and Parasitology 1988;82(1):53-7.

el-Zayadi 1985 \{published data only\}

el-Zayadi A, el Fakhfakh A, Fawzy Montasser M, Soltan YA. Effect of the oral antibilharzial niridazole (Ambilhar) on patients 
with concomitant schistosomiasis and HBs antigenaemia. Hepatogastroenterology 1985;32(4):168-70.

\section{Erikstrup 2008 \{published data only\}}

Erikstrup C, Kallestrup P, Zinyama-Gutsire RBL, Gomo E, van Dam GJ, Deelder AM, et al. Schistosomiasis and infection with human immunodeficiency virus 1 in rural Zimbabwe: systemic inflammation during co-infection and after treatment for schistosomiasis. American Journal of Tropical Medicine and Hygiene 2008;79(3):331-7.

\section{Fontanilles 1964 \{published data only\}}

Fontanilles F. New aspects of the chemotherapy of bilharziasis with Ambilhar (Niridazole). Egyptian Journal of Bilharziasis 1974;1(1):29-34.

\section{Forsyth 1964 \{published data only\}}

Forsyth DM, Bradley DJ. Long-term results of treating urinary schistosomiasis endemic in primary-school children. Lancet 1964;2(7352):171-3.

\section{Garba 2001 \{published data only\}}

Garba A, Aboubacar A, Barkire A, Vera C, Sellin B, Chippaux JP. [Impact of health education programs on the control of urinary bilharziasis in Niger]. Santé (Montrouge, France) 2001;11(1):35-42.

\section{Garba 2004 \{published data only\}}

Garba A, Campagne G, Tassie JM, Barkire A, Vera C, Sellin B, et al. [Long-term impact of a mass treatment by praziquantel on morbidity due to Schistosoma haematobium in two hyperendemic villages of Niger]. Bulletin de la Société de pathologie exotique 2004;97(1):7-11.

\section{Hammad 1997 \{published data only\}}

Hammad TA, Gabr NS, Talaat MM, Orieby A, Shawky E, Strickland GT. Hematuria and proteinuria as predictors of Schistosoma haematobium infection. American Journal of Tropical Medicine and Hygiene 1997;57(3):363-7.

\section{Jewsbury 1977 \{published data only\}}

Jewsbury JM, Cooke MJ, Weber MC. Field trial of metrifonate in the treatment and prevention of schistosomiasis infection in man. Annals of Tropical Medicine and Parasitology 1977;71(1):67-83.

\section{Jinabhai 2001 \{published data only\}}

Jinabhai CC, Taylor M, Coutsoudis A, Coovadia HM, Tomkins AM, Sullivan KR. Epidemiology of helminth infections: implications for parasite control programmes, a South African perspective. Public Health Nutrition 2001;4(6):1211-9.

\section{Jordan 1966 \{published data only\}}

Jordan P. Schistosomiasis in Tanzania: long term results of TWSb and lucanthone hydrochloride combined in suppressive therapy in Schistosoma haematobium infection. Transactions of the Royal Society of Tropical Medicine and Hygiene 1966;60(1):83-8.

\section{Kardaman 1983 \{published data only\}}

Kardaman MW, Amin MA, Fenwick A, Cheesmond AK, Dixon HG. A field trial using praziquantel (BiltricideR) to treat Schistosoma mansoni and Schistosoma haematobium infection in Gezira, Sudan. Annals in Tropical Medicine and Parasitology 1983;77(3):297-304.

\section{Kern 1984 \{published data only\}}

Kern P, Burchard GD, Dietrich M. Comparative study of oltipraz versus praziquantel for treatment of schistosomiasis with intestinal manifestation in the Gabon (Schistosoma intercalatum and S. haematobium). Tropenmedizin und Parasitologie 1984;35(2):95-9.

King 1989 \{published data only\}

King $\mathrm{CH}$, Mahmoud AA. Drugs five years later: praziquantel. Annals of Internal Medicine 1989;110(4):290-6.

\section{King 1992 \{published data only\}}

King $\mathrm{CH}$, Muchiri EM, Ouma JH. Age-targeted chemotherapy for control of urinary schistosomiasis in endemic populations. Memórias do Instituto Oswaldo Cruz 1992;87(Suppl 4):203-10.

Kurz 1986 \{published data only\}

Kurz KM, Stephenson LS, Latham MC, Kinoti SN. The effectiveness of metrifonate in reducing hookworm infection in Kenyan school children. American Journal of Tropical Medicine and Hygiene 1986;35(3):571-4.

Latham 1983 \{published data only\}

Latham MC, Stephenson LS, Hall A, Wolgemuth JC, Elliot TC, Crompton DW. Parasitic infections, anaemia and nutritional status: a study of their interrelationships and the effect of prophylaxis and treatment on workers in Kwale District, Kenya. Transactions of the Royal Society of Tropical Medicine and Hygiene 1983;77(1):41-8.

\section{Lucas 1969 \{published data only\}}

Lucas AO, Akpom CA, Cockshott WP, Bohrer SP. Reversibility of the urological lesions of schistosomiasis in children after specific therapy. Annals of the New York Academy of Sciences 1969;160(2):629-44.

\section{Mwanakasale 2009 \{published data only\}}

Mwanakasale V, Siziya S, Mwansa J, Koukounari A, Fenwick A Impact of iron supplementation on schistosomiasis control in Zambian school children in a highly endemic area. Malawi Medical Journal 2009;21(1):12-8.

\section{N'Goran 2003 \{published data only\}}

N'Goran EK, Utzinger J, Gnaka HN, Yapi A, N'Guessan NA, Kigbafori SD, et al. Randomized, double-blind, placebocontrolled trial of oral artemether for the prevention of patent Schistosoma haematobium infections. American Journal of Tropical Medicine and Hygiene 2003;68(1):24-32.

\section{Nagaty 1962 \{published data only\}}

Nagaty HF, Khalil HM. The use of tricyclamol chloride as a preventive measure for the side reactions of lucanthone hydrochloride in treatment of urinary schistosomiasis cases. Central African Journal of Medicine 1962;8:136-8. 


\section{Odongo-Aginya 1996 \{published data only\}}

Odongo-Aginya EI, Doehring M, Lakwo TL, Etyono S, Luyinda LB, Roth J, et al. Integrated control trial of schistosomiasis at Nakiwogo fishing village near Entebbe, Uganda. East African Medical Journal 1996;73(8):495-8.

\section{Olsen 2007 \{published data only\}}

Olsen A. Efficacy and safety of drug combinations in the treatment of schistosomiasis, soil-transmitted helminthiasis, lymphatic filariasis and onchocerciasis. Transactions of the Royal Society of Tropical Medicine and Hygiene 2007;101(8):747-58

\section{Pitchford 1978 \{published data only\}}

Pitchford RJ, Lewis M. Oxamniquine in the treatment of various schistosome infections in South Africa. South African Medical Journal 1978;53(17):677-80.

\section{Podgore 1994 \{published data only\}}

Podgore JK, Abu-Elyazeed RR, Mansour NS, Youssef FG, Hibbs RG, Gere JA. Evaluation of a twice-a-week application of $1 \%$ niclosamide lotion in preventing Schistosoma haematobium reinfection. American Journal of Tropical Medicine and Hygiene 1994;51(6):875-9.

\section{Rabarijaona 2001 \{published data only\}}

Rabarijaona LP, Andriamaroson BJ, Ravaoalimalala VE, Ravoniarimbinina P, Migliani R. [Identification of communities endemic for urinary bilharziosis by the "Lot Quality Assurance Sampling" method in Madagascar]. Archives de l'Institut Pasteur de Madagascar 2001;67(1-2):41-5.

\section{Rey 1984 \{published data only\}}

Rey JL, Sellin E, Sellin B, Simonkovich E, Mouchet F. Comparative efficacy of oltipraz (1 dose, $30 \mathrm{mg} / \mathrm{kg}$ ) and the combination of niridazole $(25 \mathrm{mg} / \mathrm{kg}$ ) and metrifonate $(10 \mathrm{mg} /$ $\mathrm{kg}$ ) against $\mathrm{S}$. haematobium [Efficacite comparee de l' oltipraz (1 dose $30 \mathrm{mg} / \mathrm{kg}$ ) et de l' association niridazole $(25 \mathrm{mg} / \mathrm{kg}$ ) - metrifonate $(10 \mathrm{mg} / \mathrm{kg})$ contre S. haematobium]. Medicine Tropicale 1984;44(2):155-8.

\section{Rugemalila 1984 \{published data only\}}

Rugemalila JB, Asila J, Chimbe A. Randomized comparative trials of single doses of the newer antischistosomal drugs at Mwanza, Tanzania. I. Praziquantel and oxamniquine for the treatment of schistosomiasis mansoni. Journal of Tropical Medicine and Hygiene 1984;87(6):231-5.

\section{Schutte 1983 \{published data only\}}

Schutte CH, Osman Y, Van Deventer JM, Mosese G. Effectiveness of praziquantel against the South African strains of Schistosoma haematobium and S. mansoni. South African Medical Journal 1983;64(1):7-10.

\section{Sellin 1986 \{published data only\}}

Sellin B, Rey JL, Simonkovic E, Sellin E, Mouchet F. Chemotherapy trial in the battle against $\mathrm{S}$. haematobium in an irrigated sahelian zone in Niger [Essai de lutte par chimiotherapie contre schistosoma haematobium en zone irriguee sahelienne au niger]. Medecine Tropicale 1986;46(1):21-30.

\section{Sissoko 2009 MLI \{published data only\}}

Sissoko MS, Dabo A, Traoré $H$, Diallo M, Traoré B, Konaté D, et al. Efficacy of artesunate + sulfamethoxypyrazine/pyrimethamine versus praziquantel in the treatment of Schistosoma haematobium in children. PLoS One 2009;4(10):e6732.

\section{Snyman 1997 \{published data only\}}

Snyman JR, de Sommers K, Steinmann MA, Lizamore DJ. Effects of calcitriol on eosinophil activity and antibody responses in patients with schistosomiasis. European Journal of Clinical Pharmacology 1997;52(4):277-80.

\section{Snyman 1998 \{published data only\}}

Snyman JR, Sommers de K. Effect of levamisole on the immune response of patients with schistosomiasis after treatment with praziquantel. Clinical Drug Investigation 1998;15(6):483-9.

Squires 2000 \{published data only\}

Squires N. Interventions for treating schistosomiasis haematobium. Cochrane Database of Systematic Reviews 2000, Issue 2. [DOI: 10.1002/14651858.CD000053]

\section{Stephenson 1985 \{published data only\}}

Stephenson LS, Latham MC, Kurz MK, Miller D, Kinoti SN, Oduori ML. Urinary iron loss and physical fitness of Kenyan children with urinary schistosomiasis. Americal Journal of Tropical Medicine and Hygiene 1985;34(2):322-30.

Taylor 2001 \{published data only\}

Taylor M, Jinabhai CC, Couper I, Kleinschmidt I, Jogessar VB. The effect of different anthelmintic treatment regimens combined with iron supplementation on the nutritional status of schoolchildren in KwaZulu-Natal, South Africa: a randomized controlled trial. Transactions of the Royal Society of Tropical Medicine and Hygiene 2001;95(2):211-6.

\section{Teesdale 1980 \{published data only\}}

Teesdale $\mathrm{CH}$, Chitsulo L, Mkandawire AC. Concurrent dosage with niridazole and metrifonate for the treatment of Bilharziasis in school children in Malawi. Central African Journal of Medicine 1980;26(9):202-5.

\section{Thigpen 2011 \{published data only\}}

Thigpen MC, Filler SJ, Kazembe PN, Parise ME, Macheso A, Campbell $\mathrm{CH}$, et al. Associations between peripheral Plasmodium falciparum malaria parasitemia, human immunodeficiency virus, and concurrent helminthic infection among pregnant women in Malawi. American Journal of Tropical Medicine and Hygiene 2011;84(3):379-85.

\section{Urbani 1997 \{published data only\}}

Urbani C, Touré A, Hamed AO, Albonico M, Kane I, Cheikna D, et al. Intestinal parasitic infections and schistosomiasis in the valley of the Senegal river in the Islamic Republic of Mauritania [Parasitoses intestinales et schistosomiases dans la vallee du fleuve Senegal en Republique Islamique de Mauritanie]. Médicine Tropicale 1997;57(2):157-60. 
Utzinger 2001 \{published data only\}

Utzinger J, Xiao S, N'Goran EK, Bergquist R, Tanner M. The potential of artemether for the control of schistosomiasis. International Journal for Parasitology 2001;31(14):1549-62.

\section{van Lieshout 1994 \{published data only\}}

van Lieshout L, de Jonge N, el-Masry N, Mansour MM, Bassily S, Krijger FW, et al. Monitoring the efficacy of different doses of praziquantel by quantification of circulating antigens in serum and urine of schistosomiasis patients. Parasitology 1994;108(Pt 5):519-26.

\section{Wilkins 1987 Simoto trial \{published data only\}}

Wilkins HA, Moore PJ. Comparative trials of regimens for the treatment of urinary schistosomiasis in The Gambia. Journal of Tropical Medicine and Hygiene 1987;90(2):83-92.

\section{Wolfe 1967 \{published data only\}}

Wolfe HL. Treatment of urinary schistosomiasis with niridazole (Ambilhar) in 576 African schoolchildren. Lancet 1967;1(7486):350-4

\section{Xiao 2002 \{published data only\}}

Xiao S, Tanner M, N'Goran EK, Utzinger J, Chollet J, Bergquist R, et al. Recent investigations of artemether, a novel agent for the prevention of schistosomiasis japonica, mansoni and haematobia. Acta Tropica 2002;82(2):175-81.

\section{Zwingenberger 1990 \{published data only\}}

Zwingenberger K, Feldmeier H, Bienzle U, Steiner A. Mixed Schistosoma haematobium/Schistosoma intercalatum infection. Annals of Tropical Medicine and Parasitology 1990;84(1):85-7.

\section{Additional references}

\section{Cioli 2003}

Cioli D, Pica-Mattoccia L. Praziquantel. Parasitology Research 2003;90(Suppl 1):S3-9.

\section{Cook 2003}

Manson P, Cook GC, Zumla A. Manson's Tropical diseases. 21st Edition. Philadelphia: Saunders, 2003.

\section{Doenhoff 2008}

Doenhoff MJ, Cioli D, Utzinger J. Praziquantel: mechanisms of action, resistance and new derivates for schistosomiasis. Current Opinion in Infectious Diseases 2008;21(6):659-67.

\section{Feldmeier 1999}

Feldmeier H, Chitsulo L. Therapeutic and operational profiles of metrifonate and praziquantel in Schistosoma haematobium infection. Arzneimittelforschung 1999;49(7):557-65.

\section{Fenwick 2006}

Fenwick A, Webster JP. Schistosomiasis: challenges for control, treatment and drug resistance. Current Opinion in Infectious Diseases 2006;19(6):577-82.

\section{Gray 2011}

Gray DJ, Ross AG, Li YS, McManus DP. Diagnosis and management of schistosomiasis. British Medical Journal 2011;342:d2651.

\section{Gryseels 2006}

Gryseels B, Polman K, Clerinx J, Kestens L. Human schistosomiasis. Lancet 2006;368(9541):1106-18.

\section{Higgins 2008}

Higgins JP, Altman DG. Chapter 8: Assessing risk of bias in included studies. In: Higgins JP, Green S editor(s). Cochrane Handbook for Systematic Reviews of Interventions. Chichester: John Wiley \& Sons Ltd, 2008:187-242.

\section{King 2005}

King C, Dickman K, Tisch D. Reassessment of the cost of chronic helminthic infection: a meta-analysis of disabilityrelated outcomes in endemic schistosomiasis. Lancet 2005;365(9470):1561-9.

\section{King 2011}

King CH, Olbyrch S, Soon M, Singer ME, Carter J, Colley DG. Utility of repeated praziquantel dosing in the treatment of schistosomiasis in high-risk communities in Africa: a systematic review. PLoS Neglected Tropical Diseases 2011;5(9):e1321.

\section{Lefebvre 2008}

Lefebvre C, Manheimer E, Glanville J. Chapter 6: Searching for studies. In: Higgins JPT Green S editor(s). Cochrane Handbook for Systematic Reviews of Interventions. Chichester: John Wiley \& Sons, Ltd., 2008:95-147.

\section{Liu 2011}

Liu R, Dong HF, Guo Y, Zhao QP, Jiang MS. Efficacy of praziquantel and artemisinin derivatives for the treatment and prevention of human schistosomiasis: a systematic review and meta-analysis. Parasites and Vectors 2011;4:201.

\section{Pérez del Villar 2012}

Pérez del Villar L, Burguillo FJ, López-Abán J, Muro A. Systematic review and meta-analysis of artemisinin based therapies for the treatment and prevention of schistosomiasis. PLOS One 2012;7(9):e45867.

\section{Renganathan 1998}

Renganathan E, Cioli D. An international initiative on praziquantel use. Parasitology Today 1998;14(10):390-1.

\section{Review Manager (RevMan) [Computer program]}

The Nordic Cochrane Centre, The Cochrane Collaboration. Review Manager (RevMan). Version 5.2. Copenhagen: The Nordic Cochrane Centre, The Cochrane Collaboration, 2012.

\section{Ross 2002}

Ross AG, Bartley PB, Sleigh AC, Olds GR, Li Y, Williams GM, et al. Schistosomiasis. New England Journal of Medicine 2002;346(16):1212-20. 


\section{Stothard 2013}

Stothard RJ, Sousa-Figueiredo JC, Betson M, Bustinduy A, Reinhard-Rupp J. Schistosomaisis in African infants and preschool children: let them now be treated!. Trends in Parasitology 2013;29(4):197-205.

\section{Utzinger 2004}

Utzinger J, Keiser J. Schistosomiasis and soil-transmitted helminthiasis: common drugs for treatment and control. Expert Opinion on Pharmacotherapy 2004;5(2):263-85.

\section{WHO 1985}

World Health Organization. The control of schistosomiasis. Report of a WHO Expert Committee 1985; Vol. WHO Technical Report Series 728:1-114.

\section{WHO 1991}

World Health Organization. Basic laboratory methods in medical parasitology 1) Parasitology - laboratory manuals. http://whqlibdoc.who.int/publications/9241544104_(part1).pdf 1991:1-111.

\section{WHO 1998}

World Health Organization. The use of essential drugs. http:// apps.who.int/iris/bitstream/10665/42135/1/WHO_TRS_882.pdf 1998; Vol. Eighth report of the WHO Expert Committee:1-77.

\section{WHO 2002}

World Health Organization. Prevention and control of schistosomiasis and soil-transmitted helminthiasis. Report of a WHO Expert Committee. http://whqlibdoc.who.int/trs/ WHO_TRS_912.pdf 2002:1-57.

CHARACTERISTICS OF STUDIES

Characteristics of included studies [ordered by study ID]

\section{WHO 2006}

World Health Organization. Preventive chemotherapy in human helminthiasis. Coordinated use of antihelminthic drugs in control interventions: a manual for health professionals and programme managers. http://whqlibdoc.who.int/ publications/2006/9241547103_eng.pdf 2006:1-62.

\section{WHO 2013}

World Health Organization. Schistosomiasis Fact sheet no. 115. http://www.who.int/mediacentre/factsheets/fs115/en/ index.html (accessed 25 September 2013).

\section{WHO 2014}

World Health Organization. Schistosomiasis. A major public health problem. http://www.who.int/schistosomiasis/en/ index.html (accessed 12 February 2014).

\section{References to other published versions of this review Danso-Appiah 2008}

Danso-Appiah A, Utzinger J, Liu J, Olliaro P. Drugs for treating urinary schistosomiasis. Cochrane Database of Systematic Reviews 2008, Issue 3. [DOI: 10.1002/14651858.CD000053]

\section{Squires $\mathbf{N}$}

Squires N. Interventions for treating Schistosomiasis haemtobium. Cochrane Database of Systematic Reviews 1997, Issue 3. [DOI: 10.1002/14651858.]

* Indicates the major publication for the study

Abden Abdi 1989 SOM

$\begin{array}{ll}\text { Methods } & \text { RCT } \\ & \begin{array}{l}\text { Diagnostics: egg excretion in a single, mid-day urine sample, mixing an aliquot of } 10 \mathrm{~mL} \text { urine, filtration } \\ \text { (nucleopore) }\end{array} \\ & \text { Follow-up at 1, 2, } 3 \text { and } 6 \text { months }\end{array}$

Participants
Number randomized 300
Number analysed for primary outcome at one month 201, at six months 139
Inclusion criteria: excreting 20 or more S. haematobium eggs per $10 \mathrm{~mL}$ urine
Exclusion criteria: concomitant disease

Interventions
1. Metrifonate $3 \times 7.5 \mathrm{mg} / \mathrm{kg}$ dose interval two weeks
2. Metrifonate $3 \times 5 \mathrm{mg} / \mathrm{kg}$ within one day
3. Placebo 
Abden Abdi 1989 SOM (Continued)

\begin{tabular}{ll} 
Outcomes & Cure rate \\
& Percentage egg reduction \\
& Adverse events \\
\hline Notes & Location: Somalia, southern part \\
Setting: rural, five villages \\
Endemicity: high \\
Dates: not stated \\
Source of funding: SAREC (Swedish agency for research cooperation with developing countries) \\
Authors' conclusion: Both metrifonate regimens have similar efficacy
\end{tabular}

\section{Risk of bias}

\begin{tabular}{lll}
\hline Bias & Authors' judgement & Support for judgement \\
\hline $\begin{array}{l}\text { Random sequence genera- } \\
\text { tion (selection bias) }\end{array}$ & Low risk & Randomized, randomly assigned, table of random numbers
\end{tabular}

Allocation concealment $\quad$ Low risk $\quad$ All doses were kept in coded envelopes.
(selection bias)

$\begin{aligned} & \text { Blinding of participants } \quad \text { Low risk } \\ & \text { and personnel (perfor- } \\ & \text { mance bias) }\end{aligned}$
$\begin{aligned} & \text { All outcomes } \\ & \text { ticipants were all blind to the type of treatment." }\end{aligned}$

\begin{tabular}{|c|c|c|}
\hline $\begin{array}{l}\text { Blinding of outcome as- } \\
\text { sessment (detection bias) } \\
\text { All outcomes }\end{array}$ & Low risk & Blinding of the lab technician. \\
\hline
\end{tabular}

\begin{tabular}{|c|c|c|}
\hline $\begin{array}{l}\text { Incomplete outcome data } \\
\text { (attrition bias) } \\
\text { All outcomes }\end{array}$ & High risk & $\begin{array}{l}\text { High loss to follow-up, } 33 \% \text { at one month, } 53 \% \text { at six months, balanced be- } \\
\text { tween treatment arms }\end{array}$ \\
\hline
\end{tabular}

\begin{tabular}{lll}
\hline $\begin{array}{l}\text { Selective reporting (re- } \\
\text { porting bias) }\end{array}$ & Low risk & No evidence of selective reporting. \\
\hline Other bias & Low risk & No evidence of other bias. \\
\hline
\end{tabular}

Al Aska 1990 SAU

\begin{tabular}{ll}
\hline Methods & RCT \\
& Diagnostics: ova excretion in $10 \mathrm{~mL}$ midday urine after sedimentation \\
& Follow-up: three and six months \\
\hline Participants & Adult patients referred to hospital, age not stated. Saudi and Jemeni \\
& Number randomized: not reported \\
& Number analysed: 100 \\
\hline
\end{tabular}


Al Aska 1990 SAU (Continued)

Inclusion criteria: S. haematobium infection

Exclusion criteria: none stated

Co-infection with S. mansoni

\begin{tabular}{ll}
\hline Interventions & $\begin{array}{l}\text { 1. Praziquantel } 40 \mathrm{mg} / \mathrm{kg} \text { single dose } \\
\text { 2. Metrifonate } 10 \mathrm{mg} / \mathrm{kg} \text { three doses in intervals of two weeks }\end{array}$ \\
\hline Outcomes & Cure rates \\
Failure rates & Location: Saudi Arabia \\
Sotes & Endeming: King Abdul Aziz University hospital, Riyadh. Patient referral reported \\
& Dates: not stated \\
& Funding: not stated \\
Authors' conclusion: Metrifonate and praziquantel in the stated dosage are effective against S. haema- \\
tobium, side effectives are minor and transient
\end{tabular}

\section{Risk of bias}

\begin{tabular}{lll}
\hline Bias & Authors' judgement & Support for judgement \\
\hline $\begin{array}{l}\text { Random sequence genera- } \\
\text { tion (selection bias) }\end{array}$ & Unclear risk & "allocated randomly". \\
\hline $\begin{array}{l}\text { Allocation concealment } \\
\text { (selection bias) }\end{array}$ & Unclear risk & Not mentioned. \\
\hline $\begin{array}{l}\text { Blinding of participants } \\
\text { and personnel (perfor- } \\
\text { mance bias) }\end{array}$ & Unclear risk & Not mentioned, no placebo mentioned. \\
All outcomes & \\
\hline $\begin{array}{l}\text { Blinding of outcome as- } \\
\text { sessment (detection bias) }\end{array}$ & Unclear risk & Not mentioned. \\
All outcomes & & \\
\hline $\begin{array}{l}\text { Incomplete outcome data } \\
\text { (attrition bias) }\end{array}$ & Unclear risk & Loss to follow-up not reported. \\
\begin{tabular}{l} 
All outcomes \\
\hline $\begin{array}{l}\text { Selective reporting (re- } \\
\text { porting bias) }\end{array}$
\end{tabular} & Low risk & Now baseline characteristics reported. \\
\hline \begin{tabular}{l} 
Other bias \\
\hline
\end{tabular} & Low risk & Fence of selective reporting. \\
\hline
\end{tabular}

\section{Basra 2012 GAB}

\section{Methods}

RCT 
Basra 2012 GAB (Continued)

Diagnostics: Ova excretion, microscopy in $10 \mathrm{~mL}$ urine after filtration, AMEC

Follow-up: six weeks

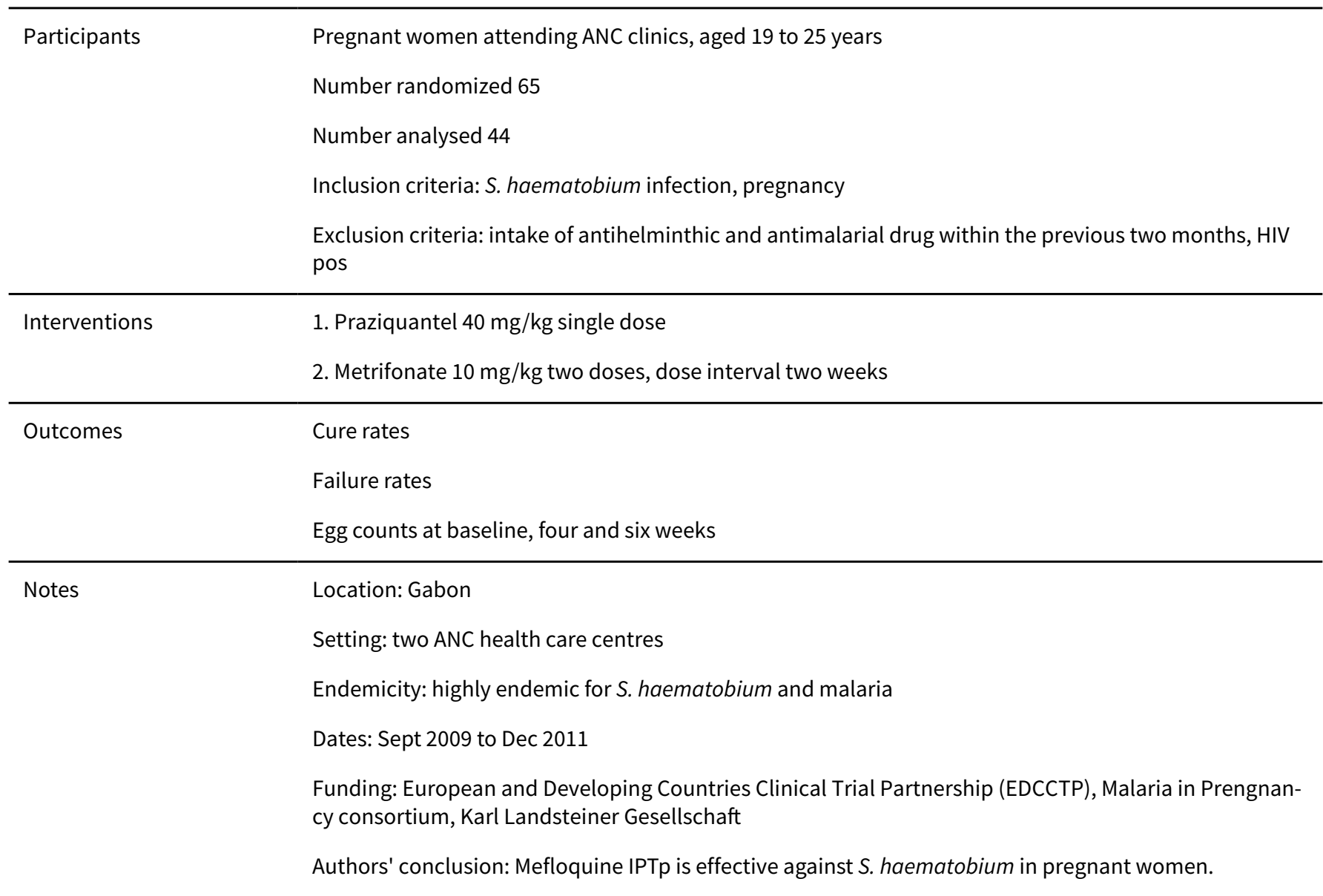

Risk of bias

\begin{tabular}{|c|c|c|}
\hline Bias & Authors' judgement & Support for judgement \\
\hline $\begin{array}{l}\text { Random sequence genera- } \\
\text { tion (selection bias) }\end{array}$ & Low risk & $\begin{array}{l}\text { The randomizations list was computer-generated and provided by the inde- } \\
\text { pendent MIPPAD trial management team. }\end{array}$ \\
\hline $\begin{array}{l}\text { Allocation concealment } \\
\text { (selection bias) }\end{array}$ & Low risk & $\begin{array}{l}\text { Trial assignment was concealed via sealed opaque envelopes which were } \\
\text { opened only after enrolment of a patient by a trial investigator. }\end{array}$ \\
\hline $\begin{array}{l}\text { Blinding of participants } \\
\text { and personnel (perfor- } \\
\text { mance bias) } \\
\text { All outcomes }\end{array}$ & High risk & Open-label. \\
\hline $\begin{array}{l}\text { Blinding of outcome as- } \\
\text { sessment (detection bias) } \\
\text { All outcomes }\end{array}$ & Low risk & Blinding of outcome assessors. \\
\hline $\begin{array}{l}\text { Incomplete outcome data } \\
\text { (attrition bias) } \\
\text { All outcomes }\end{array}$ & High risk & $\begin{array}{l}\text { High loss to follow-up, unbalanced (in the intervention group } 18 / 48=37.5 \% \text {, in } \\
\text { the control group } 3 / 48=6.25 \% \text { ) reasons partly stated. }\end{array}$ \\
\hline
\end{tabular}


Basra 2012 GAB (Continued)

Selective reporting (re- Low risk No evidence of selective outcome reporting.
porting bias)

Other bias Low risk No risk of other bias.

Befidi Mengue 1992 CMR

\begin{tabular}{ll}
\hline Methods & RCT \\
& Diagnostics: urine sample preserved with 5 mg sodium azide, sedimentation for one hour, examination \\
of sediment, egg count \\
Follow-up: six months (as only time point)
\end{tabular}

\begin{tabular}{ll}
\hline Participants & Male primary school students, aged six to 15 years \\
Number randomized 653,436 in groups of interest for this review \\
Exclusion: heavy S. haematobium infections (> 499 eggs $/ 10 \mathrm{~mL}$ ) \\
Inclusion: positive for S. haematobium
\end{tabular}

Interventions
1. Praziquantel $40 \mathrm{mg} / \mathrm{kg}$ single dose
2. Placebo
Outcomes Geometric mean egg counts
Weight
Height
Height for age
Weigth for age
Weight for height
MUAC
Triceps skinfold thickness
Mean muscle mass
$\mathrm{Hb}$ (reported in a separate publication Befidi Mengue 1993, see reference Befidi Mengue 1992 CMR) with slightly higher numbers of participants: 771 randomized, 518 in treatment groups of interest of this review).

Setting: urban (capital city of Eastern province), primary school

Endemicity: polyparasitism is common

Dates: not reported

Funding: USAID Cameroon health constraints to rural production project 1608 - 1408

Authors' conclusion: only demonstrable effect of a single praziquantel treatment on MUAC

\section{Risk of bias}

Drugs for treating urinary schistosomiasis (Review)

Copyright $\odot 2014$ The Authors. Cochrane Database of Systematic Reviews published by John Wiley \& Sons, Ltd. on behalf of The Cochrane

Collaboration. 
Befidi Mengue 1992 CMR (Continued)

\section{Bias Authors' judgement Support for judgement}

Random sequence genera- Unclear risk Randomly assigned, method not stated.

tion (selection bias)

Allocation concealment Unclear risk Not mentioned.

(selection bias)

Blinding of participants Low risk The placebo tablets were physically identical to the praziquantel tablets.

and personnel (perfor-

mance bias)

All outcomes

Blinding of outcome as- Unclear risk Not stated.

sessment (detection bias)

All outcomes

Incomplete outcome data Unclear risk Loss to follow-up unclear, as numbers followed up not reported.
(attrition bias)

All outcomes

Selective reporting (re- Low risk No evidence for selective reporting.
porting bias)

Other bias Low risk No evidence for other bias.

Borrmann 2001 GAB

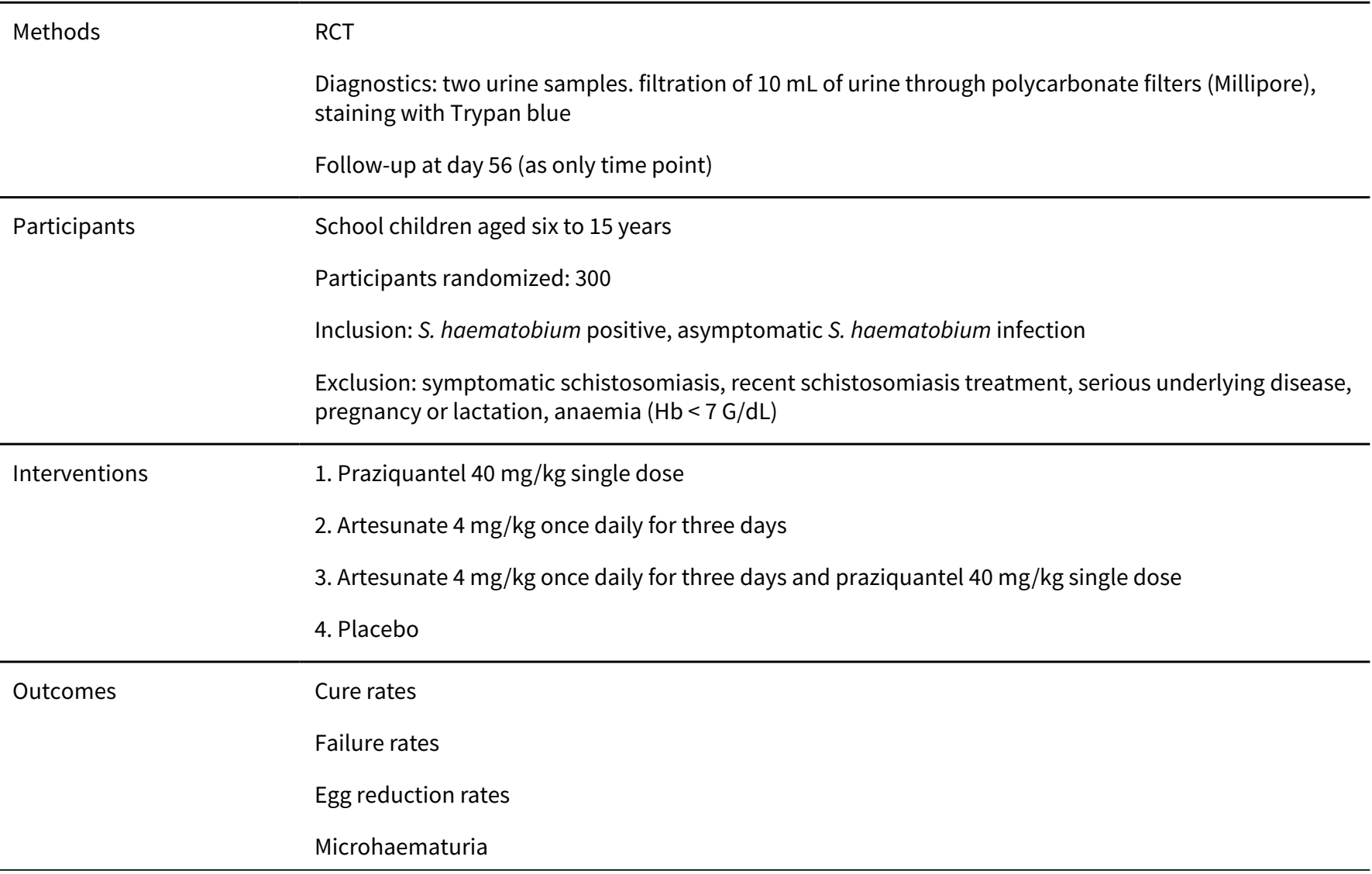

Drugs for treating urinary schistosomiasis (Review)

Copyright $\odot 2014$ The Authors. Cochrane Database of Systematic Reviews published by John Wiley \& Sons, Ltd. on behalf of The Cochrane

Collaboration. 
Borrmann 2001 GAB (Continued)

(Adverse events day seven)

Location: Gabon, province Moyen Ogone
Setting: rural villages
Endemicity: high (prevalence $80 \%$ in school children)
Dates: Oct. 2000 to Feb 2001
Funding: tablet donation Sanofi (Artesunate), Medochemie (Praziquantel)
Authors' conclusions: Efficacy of artesunate for S. haematobium treatment as single medication or in
combination is low.

\section{Risk of bias}

\begin{tabular}{|c|c|c|}
\hline Bias & Authors' judgement & Support for judgement \\
\hline $\begin{array}{l}\text { Random sequence genera- } \\
\text { tion (selection bias) }\end{array}$ & Low risk & The randomization code was generated by computer. \\
\hline $\begin{array}{l}\text { Allocation concealment } \\
\text { (selection bias) }\end{array}$ & Low risk & $\begin{array}{l}\text { The trial drugs were prepared in plastic bags, which were labelled sequentially } \\
\text { with treatment numbers according to the randomization code. }\end{array}$ \\
\hline $\begin{array}{l}\text { Blinding of participants } \\
\text { and personnel (perfor- } \\
\text { mance bias) } \\
\text { All outcomes }\end{array}$ & Low risk & $\begin{array}{l}\text { Double blind. } \\
\text { Praziquantel placebo and artesunate placebo were identical in appearance to } \\
\text { the respective active substance tablets. }\end{array}$ \\
\hline $\begin{array}{l}\text { Blinding of outcome as- } \\
\text { sessment (detection bias) } \\
\text { All outcomes }\end{array}$ & Unclear risk & Not mentioned. \\
\hline $\begin{array}{l}\text { Incomplete outcome data } \\
\text { (attrition bias) } \\
\text { All outcomes }\end{array}$ & Low risk & Low loss to follow-up (7.6\%). \\
\hline $\begin{array}{l}\text { Selective reporting (re- } \\
\text { porting bias) }\end{array}$ & Unclear risk & $\begin{array}{l}\text { Haemoglobin measurements, proteinuria and leucocyturia at day } 56 \text { not re- } \\
\text { ported. }\end{array}$ \\
\hline Other bias & Low risk & No evidence for other bias. \\
\hline
\end{tabular}

Davis 1981 ZMB

$\begin{array}{ll}\text { Methods } & \text { RCT } \\ & \begin{array}{l}\text { Diagnostics: three successive daily schistosome egg counts made on a random } 10 \mathrm{~mL} \text { urine sub sample } \\ \text { of the total bladder content by a filtration staining technique; quantitative hatching technique (enu- } \\ \text { meration of miracidia, recently dead eggs and black eggs) }\end{array} \\ & \text { Follow-up: three consecutive daily urine samples, quantitative hatching test } \\ & \text { Follow-up: at } 1,3,7,12 \text { and } 24 \text { months }\end{array}$

Participants

School children aged seven to 17 years

Number followed up after one month 151, number randomized not reported 
Davis 1981 ZMB (Continued)

Inclusion: S. haematobium positive

Exclusion: pregnant or lactating women, no serious acute coexistent diseases or complications, no other treatment during the past six months, older than six years

\begin{tabular}{ll}
\hline Interventions & 1. Praziquantel $30 \mathrm{mg} / \mathrm{kg}$ single dose \\
2. Praziquantel $40 \mathrm{mg} / \mathrm{kg}$ single dose \\
3. Praziquantel $20 \mathrm{mg} / \mathrm{kg} 2 \times$ daily \\
\hline Outcomes & Cure rate \\
Failure rate & Location: Zambia, Ndola \\
Setting: eight rural schools & Dates: not reported \\
Endemicity: high \\
Funding: Parasitic Disease Programme for Research and Training in Tropical diseases \\
Authors' conclusion: treatment groups clinically and statistically comparable
\end{tabular}

\section{Risk of bias}

\begin{tabular}{|c|c|c|}
\hline Bias & Authors' judgement & Support for judgement \\
\hline $\begin{array}{l}\text { Random sequence genera- } \\
\text { tion (selection bias) }\end{array}$ & Low risk & Randomly assigned, random number table. \\
\hline $\begin{array}{l}\text { Allocation concealment } \\
\text { (selection bias) }\end{array}$ & Unclear risk & Not mentioned. \\
\hline $\begin{array}{l}\text { Blinding of participants } \\
\text { and personnel (perfor- } \\
\text { mance bias) } \\
\text { All outcomes }\end{array}$ & Low risk & Single blind technique. \\
\hline $\begin{array}{l}\text { Blinding of outcome as- } \\
\text { sessment (detection bias) } \\
\text { All outcomes }\end{array}$ & Unclear risk & Not mentioned. \\
\hline $\begin{array}{l}\text { Incomplete outcome data } \\
\text { (attrition bias) } \\
\text { All outcomes }\end{array}$ & Low risk & Low loss to follow-up ( $3.7 \%$ to $6 \%$ ) at 1,3 and 7 months. \\
\hline $\begin{array}{l}\text { Selective reporting (re- } \\
\text { porting bias) }\end{array}$ & Low risk & $\begin{array}{l}\text { No evidence of selective reporting (some investigations at baseline not report- } \\
\text { ed). }\end{array}$ \\
\hline Other bias & Low risk & No evidence of other bias. \\
\hline
\end{tabular}

Methods RCT


de Jonge 1990 SDN (Continued)

Diagnostics: urine collection after $250 \mathrm{~mL}$ soda drink at midday. Trypan blue staining technique (if the egg concentration was less than 10 eggs per $10 \mathrm{~mL}$ urine, the whole volume (up to $350 \mathrm{~mL}$ ) was filtered).

Follow-up one and five months

\begin{tabular}{|c|c|}
\hline \multirow[t]{4}{*}{ Participants } & Male primary school children aged six to 11 years \\
\hline & $\begin{array}{l}\text { Patients randomized 160, participants randomized into treatment groups of interest for this review: } \\
107\end{array}$ \\
\hline & Inclusion: co-infection with S. haematobium and S. mansoni \\
\hline & Exclusion: not reported \\
\hline
\end{tabular}

Interventions
$\begin{aligned} & \text { 2. Metrifonate } 2 \times 10 \mathrm{mg} / \mathrm{kg} \text {, dose interval } 14 \text { weeks } \\ & \text { 3. Oxaminique } 60 \mathrm{mg} / \mathrm{kg} \text { single dose } \\ & \text { 4. Multivitamin single dose }\end{aligned}$

\begin{tabular}{ll}
\hline Outcomes & Failure \\
& Egg count \\
\hline Notes & Location: Sudan Gezira \\
& Setting: rural, village primary schools \\
& Funding: Science and Technology for Development, EC, WHO, UNDP, World bank, Special Programme \\
& for Training \& Research. Gesellschaft für technische Zusammenarbeit \\
& Dates: not reported \\
& Endemicity: high for both S. mansoni and S. haematobium \\
& Authors' conclusion: discussion of correlation of parasitological outcomes and CAA titres
\end{tabular}

\section{Risk of bias}

\begin{tabular}{lll}
\hline Bias & Authors' judgement & Support for judgement \\
\hline $\begin{array}{l}\text { Random sequence genera- } \\
\text { tion (selection bias) }\end{array}$ & Unclear risk & "randomly divided". \\
\hline $\begin{array}{l}\text { Allocation concealment } \\
\text { (selection bias) }\end{array}$ & Unclear risk & Not mentioned. \\
\hline $\begin{array}{l}\text { Blinding of participants } \\
\text { and personnel (perfor- } \\
\text { mance bias) }\end{array}$ & Unclear risk & Multivitamin as placebo, but blinding not mentioned. \\
All outcomes & \\
\hline $\begin{array}{l}\text { Blinding of outcome as- } \\
\text { sessment (detection bias) } \\
\text { All outcomes }\end{array}$ & Unclear risk & Not mentioned. \\
\hline
\end{tabular}

Incomplete outcome data High risk Loss to follow-up high, at one months up to 23\%, at five months up to $28 \%$.
(attrition bias)


de Jonge 1990 SDN (Continued)

All outcomes

Selective reporting (re- Low risk No evidence for selective reporting.

porting bias)

Other bias Low risk No evidence for other bias.

Methods
Diagnostics: collection of two urine samples at midday (12.00 to 14.00) after exercise on two consec-
utive days, agitation of urine sample, preservation of eggs, staining (1\% aqueous solution, carbol
fuchsin), filtration, egg counts
Follow-up at eight weeks (as only time point)

Participants

School children aged four to 20 years (nursery school, primary and junior secondary schools, students)

Number randomized 260 children into five groups

Inclusion: healthy, able to swallow the medication

Exclusion: serious underlying disease, recent treatment for schistosomiasis, $>20 \mathrm{yrs},<4 \mathrm{yrs}$ old

I. Praziquantel $40 \mathrm{mg} / \mathrm{kg}$ single dose and placebo
2. Praziquantel $40 \mathrm{mg} / \mathrm{kg}$ single dose only
3. Artesunate $4 \mathrm{mg} / \mathrm{kg} 1 \times$ daily for three days and placebo
4. Artesunate $4 \mathrm{mg} / \mathrm{kg} 1 \times$ daily for three days only
5. Praziquantel $40 \mathrm{mg} / \mathrm{kg}$ single dose and artesunate $4 \mathrm{mg} / \mathrm{kg} 1 \times$ daily for three days
6. Placebo and placebo

Outcomes Cure

Egg counts and egg reduction rate

Haematuria

Proteinuria

Notes

Location: Nigeria, Adim community, Cross Rlver State

Setting: school students

Dates: August 2005 to June 2006

Endemicity: seasonal transmission

Funding: partly funded by the management of the University of Calabar

Authors' conclusion: both praziquantel and artesunate in the stated doses are safe, well-tolerated and effective in the trial area. Combined treatment is more effective and single treatment with any of the drugs.

\section{Risk of bias}

Drugs for treating urinary schistosomiasis (Review) 
Inyang Etoh 2009 NGA (Continued)

\begin{tabular}{|c|c|c|}
\hline Bias & Authors' judgement & Support for judgement \\
\hline $\begin{array}{l}\text { Random sequence genera- } \\
\text { tion (selection bias) }\end{array}$ & Unclear risk & "randomised". \\
\hline $\begin{array}{l}\text { Allocation concealment } \\
\text { (selection bias) }\end{array}$ & Unclear risk & Not mentioned. \\
\hline $\begin{array}{l}\text { Blinding of participants } \\
\text { and personnel (perfor- } \\
\text { mance bias) } \\
\text { All outcomes }\end{array}$ & Unclear risk & $\begin{array}{l}\text { Placebo not identical in appearance. } \\
\text { Blinding not mentioned. }\end{array}$ \\
\hline $\begin{array}{l}\text { Blinding of outcome as- } \\
\text { sessment (detection bias) } \\
\text { All outcomes }\end{array}$ & Unclear risk & Not mentioned. \\
\hline $\begin{array}{l}\text { Incomplete outcome data } \\
\text { (attrition bias) } \\
\text { All outcomes }\end{array}$ & Unclear risk & Loss to follow-up of $15.4 \%$ and $19.2 \%$ at day 56 . \\
\hline $\begin{array}{l}\text { Selective reporting (re- } \\
\text { porting bias) }\end{array}$ & Low risk & No evidence of selective reporting. \\
\hline Other bias & Low risk & No evidence of other bias. \\
\hline
\end{tabular}

Jewsbury 1976 ZWE

$\begin{array}{ll}\text { Methods } & \text { RCT } \\ & \text { Diagnostics: three urine samples on three consecutive days, determination of egg counts and cure rates } \\ \text { Follow-up at week } 11 \text { and week } 36\end{array}$

Children, aged three to 15 years (and older)
Number of children randomized: 179
Number of children analysed 114 (complete case analysis)
Inclusion: $S$. haematobium positive
Exclusion: not reported

Interventions
1. Metrifonate $7.5 \mathrm{mg} \mathrm{x} \mathrm{3,} \mathrm{dose} \mathrm{interval} \mathrm{two} \mathrm{weeks}$
2. Control: no intervention

\begin{tabular}{ll}
\hline Outcomes & Cure rate \\
& Failure rate \\
& Median urine egg counts \\
\hline Notes & Location: Zimbabwe near Salibury \\
& Setting: rural, four farms \\
& Dates: not reported
\end{tabular}

Drugs for treating urinary schistosomiasis (Review) 
Jewsbury 1976 ZWE (Continued)

Endemicity: high (pre-infection rate with S. haematobium 80\%)

Funding: Drug donation by Bayer

Authors' conclusion: Metrifonate is safe and effective for the treatment of S. haematobium

\section{Risk of bias}

\begin{tabular}{|c|c|c|}
\hline Bias & Authors' judgement & Support for judgement \\
\hline $\begin{array}{l}\text { Random sequence genera- } \\
\text { tion (selection bias) }\end{array}$ & Unclear risk & "randomised". \\
\hline $\begin{array}{l}\text { Allocation concealment } \\
\text { (selection bias) }\end{array}$ & Unclear risk & Not mentioned. \\
\hline $\begin{array}{l}\text { Blinding of participants } \\
\text { and personnel (perfor- } \\
\text { mance bias) } \\
\text { All outcomes }\end{array}$ & Unclear risk & Not mentioned. \\
\hline $\begin{array}{l}\text { Blinding of outcome as- } \\
\text { sessment (detection bias) } \\
\text { All outcomes }\end{array}$ & Unclear risk & Not mentioned. \\
\hline $\begin{array}{l}\text { Incomplete outcome data } \\
\text { (attrition bias) } \\
\text { All outcomes }\end{array}$ & High risk & $\begin{array}{l}\text { Participant numbers not reported at week } 11 \text {, high loss to follow-up of } 46 \% \text { at } \\
\text { week } 36 .\end{array}$ \\
\hline $\begin{array}{l}\text { Selective reporting (re- } \\
\text { porting bias) }\end{array}$ & Unclear risk & Data of week 11 not reported. \\
\hline Other bias & High risk & $\begin{array}{l}\text { Baseline imbalance; for the infected, untreated control group, an infection rate } \\
\text { of } 89.4 \% \text { is given at baseline. }\end{array}$ \\
\hline
\end{tabular}

\section{Kardaman 1985 SDN}

Methods RCT

Diagnostics: centrifugation, sediment taken for egg counts

Follow-up at five weeks and three months

Sarticipants
Number of children included: 237
Inclusion: co-infection S. haematobium and S. mansoni
Exclusion: receiving medication for any other infection, treatment for schistosomiasis during the pre-
ceding 6 months.

Interventions

1. Praziquantel $40 \mathrm{mg} / \mathrm{kg}$ single dose

2. Praziquantel $2 \times 20 \mathrm{mg} / \mathrm{kg}$ in one day, dose interval four to six hours

\begin{tabular}{ll}
\hline Outcomes & Cure \\
& Failure
\end{tabular}

Drugs for treating urinary schistosomiasis (Review)

Copyright $\odot 2014$ The Authors. Cochrane Database of Systematic Reviews published by John Wiley \& Sons, Ltd. on behalf of The Cochrane

Collaboration. 
Kardaman 1985 SDN (Continued)

$$
\text { Adverse events }
$$

Location: Sudan, Galaga Village
Setting: rural, primary schools
Dates: not reported
Endemicity: high (mixed infections common)
Funding: Parasitic disease programme, WHO
Authors' conclusion: Results of two regimens not significantly different. Treatment for this setting has
to be repeated every six months.

\section{Risk of bias}

\begin{tabular}{|c|c|c|}
\hline Bias & Authors' judgement & Support for judgement \\
\hline $\begin{array}{l}\text { Random sequence genera- } \\
\text { tion (selection bias) }\end{array}$ & Unclear risk & Randomly assigned. \\
\hline $\begin{array}{l}\text { Allocation concealment } \\
\text { (selection bias) }\end{array}$ & Unclear risk & Not mentioned. \\
\hline $\begin{array}{l}\text { Blinding of participants } \\
\text { and personnel (perfor- } \\
\text { mance bias) } \\
\text { All outcomes }\end{array}$ & Unclear risk & Not mentioned. \\
\hline $\begin{array}{l}\text { Blinding of outcome as- } \\
\text { sessment (detection bias) } \\
\text { All outcomes }\end{array}$ & Unclear risk & Not mentioned. \\
\hline $\begin{array}{l}\text { Incomplete outcome data } \\
\text { (attrition bias) } \\
\text { All outcomes }\end{array}$ & Low risk & Loss to follow-up at five weeks up to $4.7 \%$, at three months up to $8.4 \%$. \\
\hline $\begin{array}{l}\text { Selective reporting (re- } \\
\text { porting bias) }\end{array}$ & Low risk & No evidence for selective reporting. \\
\hline Other bias & Low risk & No evidence for other bias. \\
\hline
\end{tabular}

Keiser 2010 CIV

$\begin{array}{ll}\text { Methods } & \text { RCT } \\ \text { Diagnostics: collection of two urine specimen at midday (10.00 to } 14.00) \text {, samples were rigorously shak- } \\ \text { en, filtration of } 10 \mathrm{~mL} \text { through a } 13 \mathrm{~mL} \text { filter with } 25 \mu \mathrm{m} \text { diameter } \\ \text { Follow-up at } 26 \text { days }\end{array}$

Participants
Participants randomized 83
Inclusion: confirmed S. haematobium infection


Keiser 2010 CIV (Continued)

$$
\text { Exclusion: not reported }
$$

Interventions Praziquantel $40 \mathrm{mg} / \mathrm{kg}$ single dose
2. Mefloquine $25 \mathrm{mg} / \mathrm{kg}$ single dose
3. Artesunate $4 \mathrm{mg} / \mathrm{kg} 1 \times$ daily for three days
4. Artesunate $3 \times 100 \mathrm{mg}$ and mefloquine $250 \mathrm{mg}$

\begin{tabular}{ll}
\hline Outcomes & Cure rates \\
& Failure rate \\
& Egg count \\
& Egg reduction rate \\
& Adverse effects
\end{tabular}

Location: Cote d' Ivoire, district Agboville
Setting: rural, school children
Dates: November to December 2009
Funding: support Dafra Pharma, Mepha for drug donations
Endemicity: highly endemic, $40 \%$ among school children
Authors' conclusion: High cure rates with praziquantel, promising results for mefloquine - artesunate
(in the standard dose for malaria)

\section{Risk of bias}

\begin{tabular}{|c|c|c|}
\hline Bias & Authors' judgement & Support for judgement \\
\hline $\begin{array}{l}\text { Random sequence genera- } \\
\text { tion (selection bias) }\end{array}$ & Unclear risk & $\begin{array}{l}\text { "using a computer generated randomisation code". Seven children were } \\
\text { added to one treatment group in a non-randomized manner. }\end{array}$ \\
\hline $\begin{array}{l}\text { Allocation concealment } \\
\text { (selection bias) }\end{array}$ & High risk & Not implemented (email correspondence with author). \\
\hline $\begin{array}{l}\text { Blinding of participants } \\
\text { and personnel (perfor- } \\
\text { mance bias) } \\
\text { All outcomes }\end{array}$ & High risk & Open label. \\
\hline $\begin{array}{l}\text { Blinding of outcome as- } \\
\text { sessment (detection bias) } \\
\text { All outcomes }\end{array}$ & Unclear risk & Not mentioned. \\
\hline $\begin{array}{l}\text { Incomplete outcome data } \\
\text { (attrition bias) } \\
\text { All outcomes }\end{array}$ & Low risk & No loss to follow-up during the trial (day 26). \\
\hline $\begin{array}{l}\text { Selective reporting (re- } \\
\text { porting bias) }\end{array}$ & Low risk & $\begin{array}{l}\text { Urinary findings day } 26 \text { not reported (not available, email correspondence } \\
\text { with author). }\end{array}$ \\
\hline Other bias & Low risk & No evidence of other sources of bias. \\
\hline
\end{tabular}




$\begin{array}{ll}\text { Methods } & \text { RCT } \\ & \begin{array}{l}\text { Diagnostics: collection of midday urine sample (10.00 to 13.00), urine filtration technique with nucleo- } \\ \text { pore filters, egg count } \\ \text { Follow-up at two to three months }\end{array}\end{array}$

\begin{tabular}{ll}
\hline Participants & Primary school students aged five to 17 years and adult participants over 20 years \\
& Number of patients randomized 280 (34 adults, 246 children) \\
Inclusion: egg count $>50$ eggs $/ 10 \mathrm{~mL}$ urine \\
Exclusion: not reported
\end{tabular}

Interventions Praziquantel $10 \mathrm{mg} / \mathrm{kg}$ single dose
2. Praziquantel $20 \mathrm{mg} / \mathrm{kg}$ single dose
3. Praziquantel $30 \mathrm{mg} / \mathrm{kg}$ single dose
4. Praziquantel $40 \mathrm{mg} / \mathrm{kg}$ single dose

\begin{tabular}{ll}
\hline Outcomes & Cure \\
Egg counts \\
Severity of infection \\
Proteinuria \\
Haematuria \\
Location: Kenya, Kwale district \\
Setting: rural, primary schools \\
Dates: not reported \\
Endemicity: high \\
Funding: Edna McConnell Clark Foundation \\
Authors' conclusion: low dose (20 mg/ $/ \mathrm{kg})$ is as effective as standard dose (40 mg/kg) of praziquantel \\
(reductions in parasite burden and morbidity) for population based control programmes
\end{tabular}

\section{Risk of bias}

\begin{tabular}{|c|c|c|}
\hline Bias & Authors' judgement & Support for judgement \\
\hline $\begin{array}{l}\text { Random sequence genera- } \\
\text { tion (selection bias) }\end{array}$ & Low risk & Random allocation, pre-randomized cards. \\
\hline $\begin{array}{l}\text { Allocation concealment } \\
\text { (selection bias) }\end{array}$ & Unclear risk & Not mentioned. \\
\hline $\begin{array}{l}\text { Blinding of participants } \\
\text { and personnel (perfor- } \\
\text { mance bias) } \\
\text { All outcomes }\end{array}$ & High risk & Clinicians not blinded to the intervention. \\
\hline
\end{tabular}

Drugs for treating urinary schistosomiasis (Review) 
King 1989 KEN (Continued)

Blinding of outcome as- Low risk Outcome assessors and laboratory staff blinded to the intervention. sessment (detection bias)

All outcomes

\begin{tabular}{|c|c|c|}
\hline $\begin{array}{l}\text { Incomplete outcome data } \\
\text { (attrition bias) }\end{array}$ & Low risk & $\begin{array}{l}\text { Loss to follow-up at two to three months } 9 \% \text { to } 14 \% \text {, balanced between } \\
\text { groups. }\end{array}$ \\
\hline
\end{tabular}

All outcomes groups.

\begin{tabular}{lll}
\hline $\begin{array}{l}\text { Selective reporting (re- } \\
\text { porting bias) }\end{array}$ & Low risk & No evidence of selective reporting. \\
\hline Other bias & Low risk & No evidence for other sources of bias. \\
\hline
\end{tabular}

King 1990 KEN

\begin{tabular}{ll}
\hline Methods & RCT \\
& Diagnostics: sample collection of midday urine (10.00 to 13.00), nucleopore filtration, egg counts \\
Follow-up at one, two and three years
\end{tabular}

\begin{tabular}{|c|c|}
\hline Participants & $\begin{array}{l}\text { Primary school children aged four to } 21 \text { years } \\
\text { Number randomized } 1813 \\
\text { Inclusion: S. haematobium positive } \\
\text { Exclusion: not reported }\end{array}$ \\
\hline Interventions & $\begin{array}{l}\text { 1. Praziquantel } 40 \mathrm{mg} / \mathrm{kg} \text { single dose once a year } \\
\text { 2. Metrifonate } 10 \mathrm{mg} / \mathrm{kg} \text { single dose three times a year, dose interval four months }\end{array}$ \\
\hline Outcomes & $\begin{array}{l}\text { Haematuria } \\
\text { Proteinuria } \\
\text { Ultrasound (hydronephrosis, bladder thickening, bladder deformity) }\end{array}$ \\
\hline Notes & $\begin{array}{l}\text { Location: Kenya, Coast Province, Kwale Province, Msambweni Area } \\
\text { Setting: rural, primary schools, nine villages } \\
\text { Dates: } 1984 \\
\text { Endemicity: high (prevalence in school children } 60 \% \text { to } 85 \% \text { ) } \\
\text { Funding: Edna McConnell Clark Foundation, WHO, Rockefeller Foundation } \\
\text { Authors' conclusion: Both regimens had significant effects on the prevalence of hematuria, protein- } \\
\text { uria, and bladder abnormalities. no significant differences between the two drugs. No effect on hy- } \\
\text { dronephrosis at twelve months. }\end{array}$ \\
\hline
\end{tabular}

\section{Risk of bias}

\begin{tabular}{lll}
\hline Bias & Authors' judgement & Support for judgement \\
\hline $\begin{array}{l}\text { Random sequence genera- } \\
\text { tion (selection bias) }\end{array}$ & Low risk & Random allocation with pre-randomized cards. \\
\hline \hline
\end{tabular}

Drugs for treating urinary schistosomiasis (Review)

Copyright $\odot 2014$ The Authors. Cochrane Database of Systematic Reviews published by John Wiley \& Sons, Ltd. on behalf of The Cochrane

Collaboration. 


\section{King 1990 KEN (Continued)}

\begin{tabular}{|c|c|c|}
\hline $\begin{array}{l}\text { Allocation concealment } \\
\text { (selection bias) }\end{array}$ & High risk & $\begin{array}{l}\text { "Treatment allocation was not concealed to the investigators" (email corre- } \\
\text { spondence with author). }\end{array}$ \\
\hline
\end{tabular}

Blinding of participants and personnel (performance bias)

All outcomes

High risk

Blinding of participants (different taste and appearance of commercially purchased drugs) email response).

no blinding of clinicians

\begin{tabular}{|c|c|c|}
\hline $\begin{array}{l}\text { Blinding of outcome as- } \\
\text { sessment (detection bias) } \\
\text { All outcomes }\end{array}$ & Low risk & $\begin{array}{l}\text { Evaluators were effectively blinded to the treatment status of the children they } \\
\text { were testing (email correspondence with author). }\end{array}$ \\
\hline $\begin{array}{l}\text { Incomplete outcome data } \\
\text { (attrition bias) } \\
\text { All outcomes }\end{array}$ & Unclear risk & Unclear. \\
\hline $\begin{array}{l}\text { Selective reporting (re- } \\
\text { porting bias) }\end{array}$ & Low risk & No evidence of selective reporting. \\
\hline Other bias & Low risk & No evidence of other bias. \\
\hline
\end{tabular}

\title{
King 2002 KEN
}

\begin{tabular}{ll}
\hline Methods & RCT \\
& Diagnostics: Collection of two mid-day (10:00 to 14:00) on different days, filtration, Nucleopore) Intensi- \\
& ty of infection assigned according to the highest one day egg count in the repeated daily testing. \\
Follow-up at six weeks and nine months
\end{tabular}

Participants
Number of participants randomized 291
Inclusion: S. haematobium positive
Exclusion: not reported

$\begin{array}{ll}\text { Interventions } & \text { 1. Praziquantel } 40 \mathrm{mg} / \mathrm{kg} \text { single dose } \\ \text { 2. Praziquantel } 20 \mathrm{mg} / \mathrm{kg} \text { single dose }\end{array}$

Outcomes Cure

\section{Egg count}

Ultrasound findings (Hydronephrosis, bladder thickening and bladder irregularity)

Notes

\author{
Location: Kenya, Coastal Province, Kwale District \\ Setting: rural, village schools \\ Dates: 1992 to 1993 \\ Endemicity: high \\ Funding: WHO, TDR, Rockefeller Foundation Joint Funding Venture and National Institutes of Health
}


King 2002 KEN (Continued)

Authors' conclusion: Praziquantel $20 \mathrm{mg}$ and praziquantel $40 \mathrm{mg}$ are equally effective in reducing structural urinary tract morbidity over nine months. A praziquantel dose of $20 \mathrm{mg} / \mathrm{kg}$ may be sufficient for practical control of renal and bladder morbidity due to $S$. haematobium in certain settings: not reported

(trial might be underpowered for ultrasound findings).

\section{Risk of bias}

\begin{tabular}{|c|c|c|}
\hline Bias & Authors' judgement & Support for judgement \\
\hline $\begin{array}{l}\text { Random sequence genera- } \\
\text { tion (selection bias) }\end{array}$ & Low risk & $\begin{array}{l}\text { "Infected students were then individually randomised to therapy...by comput- } \\
\text { er random number generation." }\end{array}$ \\
\hline $\begin{array}{l}\text { Allocation concealment } \\
\text { (selection bias) }\end{array}$ & High risk & Allocation was not concealed. \\
\hline $\begin{array}{l}\text { Blinding of participants } \\
\text { and personnel (perfor- } \\
\text { mance bias) } \\
\text { All outcomes }\end{array}$ & High risk & $\begin{array}{l}\text { No blinding of personnel: "Dosing assignment lists were transmitted to clinical } \\
\text { staff responsible for treatment". }\end{array}$ \\
\hline $\begin{array}{l}\text { Blinding of outcome as- } \\
\text { sessment (detection bias) } \\
\text { All outcomes }\end{array}$ & Low risk & $\begin{array}{l}\text { Blinding of outcome assessors (clinicians, parasitologists). } \\
\text { "Assignments were masked form staff parasitologists and physicians responsi- } \\
\text { ble for follow-up until the end of the study." }\end{array}$ \\
\hline $\begin{array}{l}\text { Incomplete outcome data } \\
\text { (attrition bias) } \\
\text { All outcomes }\end{array}$ & High risk & Loss to follow-up $31 \%$ at six weeks. \\
\hline $\begin{array}{l}\text { Selective reporting (re- } \\
\text { porting bias) }\end{array}$ & Low risk & No evidence of selective outcome reporting. \\
\hline Other bias & Low risk & Important baseline characteristics (egg counts) not reported at baseline. \\
\hline
\end{tabular}

McMahon 1979 TZA

\begin{tabular}{ll}
\hline Methods & RCT \\
& Diagnostics: Collection of three midday (10.00 to 13.00) urine samples on three consecutive days, sedi- \\
mentation in a conical flask for $30 \mathrm{mins}$, taking of a $10 \mathrm{~mL}$ sample of the bottom of the flask, centrifuga- \\
tion and processing of the deposit $5 \mathrm{~mL}$ boiled, cooled water added to deposit, miracidia hatching test, \\
fixing and staining of miracidia (alcohol and eosin), microscopy and count. \\
Follow-up at one, three and six months.
\end{tabular}

\begin{tabular}{l} 
School children aged seven to 15 years \\
No. of children randomized: 138 \\
Inclusion: S. haematobium positive \\
Exclusion: not reported \\
\hline
\end{tabular}

$\begin{array}{ll}\text { Interventions } & \text { 1. Praziquantel } 30 \mathrm{mg} / \mathrm{kg} \text { single dose } \\ \text { 2. Praziquantel } 40 \mathrm{mg} / \mathrm{kg} \text { single dose }\end{array}$


McMahon 1979 TZA (Continued)

3. Praziquantel $2 \times 20 \mathrm{mg}$ in one day, dose interval four hours

4. Placebo

\begin{tabular}{ll}
\hline Outcomes & Cure \\
Egg counts \\
Adverse effects \\
\hline Location: Tanzania, Tanga region \\
Setting: school, rural area \\
Endemicity: high, transmission may vary greatly form year to year and season to season. \\
Dates: not reported \\
Funding: MRC/WHO/Tanzania Helminthiasis Research Unit, Tanga \\
Authors' conclusion: Praziquantel in the given doses is not toxic. Praziquantel 40 mg did not affect the \\
therapeutic response in children with large egg loads. \\
As cure rates are influenced by pre-treatment egg loads, trials of higher doses in patients with high egg \\
loads needed.
\end{tabular}
loads needed.

\section{Risk of bias}

\begin{tabular}{lll}
\hline Bias & Authors' judgement & Support for judgement \\
\hline $\begin{array}{l}\text { Random sequence genera- } \\
\text { tion (selection bias) }\end{array}$ & Low risk & $\begin{array}{l}\text { Randomly sub-divided into four groups according to previously arranged } \\
\text { blocks. }\end{array}$ \\
\hline $\begin{array}{l}\text { Allocation concealment } \\
\text { (selection bias) }\end{array}$ & Unclear risk & Not mentioned. \\
\hline $\begin{array}{l}\text { Blinding of participants } \\
\text { and personnel (perfor- } \\
\text { mance bias) }\end{array}$ & Unclear risk & Not mentioned. \\
All outcomes & \\
\hline
\end{tabular}

Blinding of outcome as- Unclear risk Not mentioned.

sessment (detection bias)

All outcomes

Incomplete outcome data Unclear risk Loss to follow-up $10 \%$ to $15 \%$ at 1,3 and 6 months.
(attrition bias)

All outcomes

Selective reporting (re- Low risk No evidence of selective reporting.
porting bias)

Other bias Low risk Baseline characteristics not reported.

\section{McMahon 1983 TZA}

Methods RCT


McMahon 1983 TZA (Continued)

Diagnostics: collection of two midday (10.00 to 14.00 ) samples on two consecutive days for initial diagnosis, of three samples for follow-up), quantitative hatching technique, sedimentation of $10 \mathrm{~mL}$ urine

Follow-up at two and four months

Participants
Number of participants randomized: 90
Inclusion: 250 miracidia/ $10 \mathrm{~mL}$ urine
Exclusion: not reported

Interventions
$\begin{aligned} & \text { 2. Metrifonate } 10 \mathrm{mg} / \mathrm{kg} 1 \times \text { daily, dose interval } 14 \text { days } \\ & \text { 3. Niridazole } 25 \mathrm{mg} / \mathrm{kg} 1 \text { x daily for six days, dose interval one day }\end{aligned}$

\begin{tabular}{ll}
\hline Outcomes & Cure rates \\
& Egg reduction rates \\
& Adverse effects \\
\hline Lotes & Location: Tanzania, Tanga region \\
Setting: not stated & Endemicity: high \\
& Dates: not reported \\
& Funding: MRC/WHO/Tazania Helminthiasis Research unit, Tanga, Biltricide (Praziqantel) was supplied \\
by Bayer. & $\begin{array}{l}\text { Authors conclusion: Praziquantel was more effective than metrifonate and niridazole. Side effects were } \\
\text { minor. }\end{array}$
\end{tabular}

\section{Risk of bias}

\section{Bias}

Random sequence genera- Unclear risk tion (selection bias)
Unclear risk (selection bias)

Allocation concealment Blinding of participants and personnel (performance bias)

All outcomes

High risk

\section{Authors' judgement Support for judgement}

Randomly allocated.

Not mentioned. Not mentioned; use of different regimens, no use of placebo.

\begin{tabular}{lll}
\hline $\begin{array}{l}\text { Blinding of outcome as- } \\
\text { sessment (detection bias) } \\
\text { All outcomes }\end{array}$ & Unclear risk & Not mentioned. \\
\hline $\begin{array}{l}\text { Incomplete outcome data } \\
\text { (attrition bias) }\end{array}$ & High risk & $\begin{array}{l}\text { Loss to follow-up partly high, not balanced (at four months } 0 \% \text { in the prazi- } \\
\text { quantel group, } 26 \% \text { in the metrifonate and } 30 \% \text { in the niridazole group. }\end{array}$ \\
\hline
\end{tabular}

Drugs for treating urinary schistosomiasis (Review) 
McMahon 1983 TZA (Continued)
Selective reporting (re-
Unclear risk
No evidence of selective reporting. porting bias)

Other bias

Low risk

Few baseline characteristics reported.

\section{Mott 1985 GHA}

\begin{tabular}{ll}
\hline Methods & RCT \\
Diagnostics: collection or one urine sample, two random samples out of this urine sample were \\
processed. quantitative urine filtration technique
\end{tabular}

Follow-up at three and six months

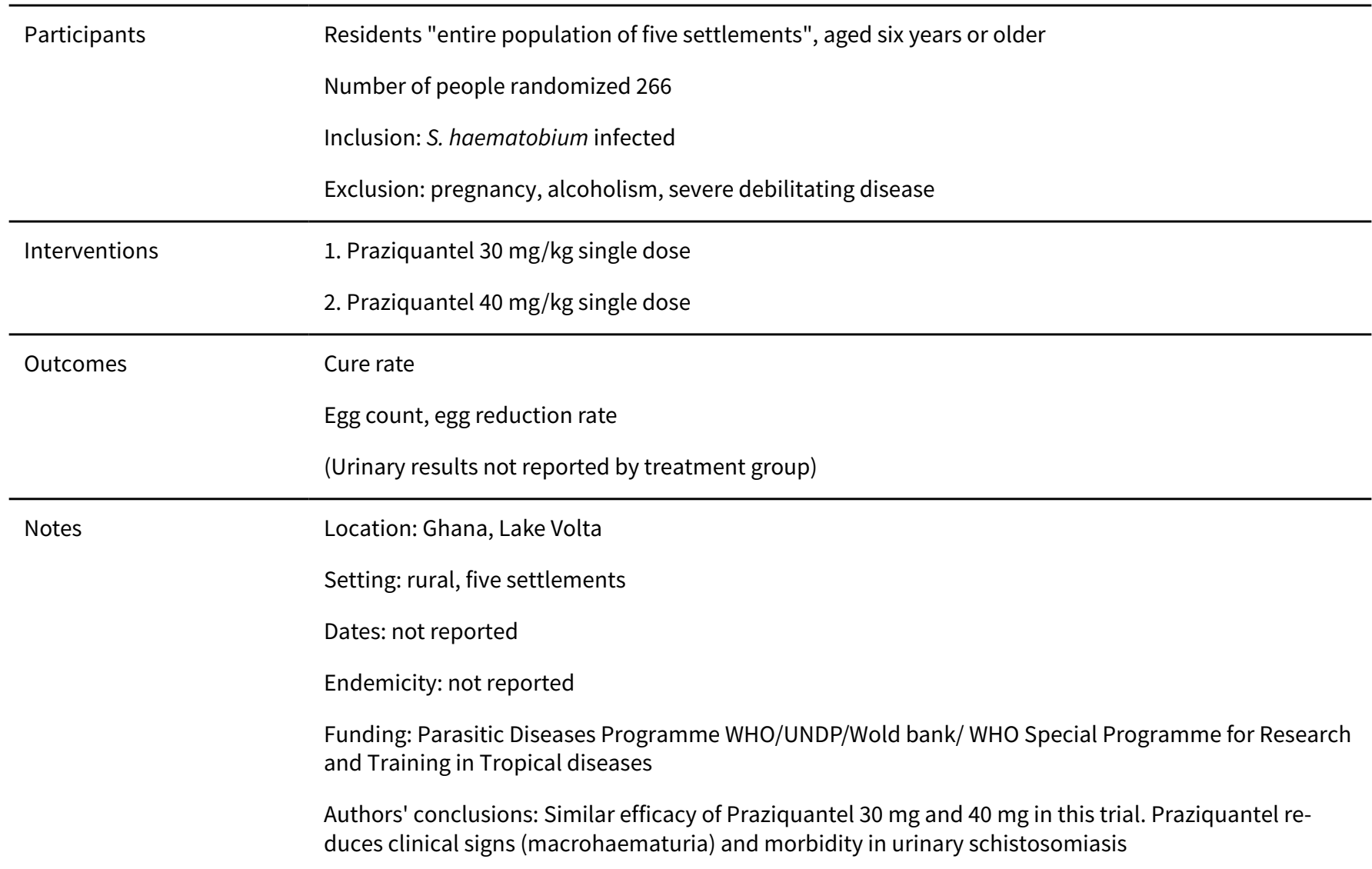

\section{Risk of bias}

\begin{tabular}{lll}
\hline Bias & Authors' judgement & Support for judgement \\
\hline $\begin{array}{l}\text { Random sequence genera- } \\
\text { tion (selection bias) }\end{array}$ & Unclear risk & Randomly assigned. \\
\hline $\begin{array}{l}\text { Allocation concealment } \\
\text { (selection bias) }\end{array}$ & Unclear risk & Not mentioned. \\
\hline
\end{tabular}

Blinding of participants Unclear risk Not mentioned.
and personnel (perfor-
mance bias)


Mott 1985 GHA (Continued)

All outcomes

Blinding of outcome as-
sessment (detection bias) $\quad$ Unclear risk Not mentioned.

sessment (detection bias)

All outcomes

Incomplete outcome data Low risk Loss to follow-up at six months $11.6 \%$.

(attrition bias)

All outcomes

Selective reporting (re- Low risk No evidence of selective reporting.
porting bias)

porting bias)

Other bias Low risk Baseline characteristics not reported per group.

\section{Olds 1999 KEN}

$\begin{array}{ll}\text { Methods } & \text { RCT } \\ \text { Diagnostics: Eggs from } 2 \times 10 \mathrm{~mL} \text { samples were filtered on membranes (Nucleopore) } \\ \text { Follow at } 45 \text { days, } 90 \text { days, six months and one year }\end{array}$

\section{Participants}

School children aged four to 18 years

Number of participants pos for S. haematobium: 380

Inclusion: S. haematobium positive

Exclusion: pregnancy or marriage, failure to submit two stool specimens prior to initial therapy, known allergy to praziquantel or albendazole, treatment within the past six months

\begin{tabular}{|c|c|}
\hline Interventions & $\begin{array}{l}\text { 1. Praziquantel } 40 \mathrm{mg} / \mathrm{kg} \text { single dose and albendazole } 400 \mathrm{mg} \text { single dose } \\
\text { 2. Praziquantel } 40 \mathrm{mg} / \mathrm{kg} \text { single dose and placebo } \\
\text { 3. Albendazole } 400 \mathrm{mg} \text { single dose and placebo } \\
\text { 4. Placebo and placebo }\end{array}$ \\
\hline Outcomes & $\begin{array}{l}\text { Cure } \\
\text { Egg count } \\
\text { Ultrasound } \\
\text { Weight, height, skinfold thickness, MUAC } \\
\mathrm{Hb} \\
\text { Adverse effects }\end{array}$ \\
\hline Notes & $\begin{array}{l}\text { Location: Kenya, Kwale District, Coast province for S. haematobium (multi centre trial for different } \\
\text { Schistosoma species, conducted in different countries) } \\
\text { Setting: rural } \\
\text { Endemicity: endemic ascariasis, hookworm, trichuris, S. haematobium } \\
\text { Dates: not reported }\end{array}$ \\
\hline
\end{tabular}


Funding: WHO/TDR Tropical disease research

Authors' conclusion: Combined mass treatment of children with albendazole and praziquantel produced not more side effects than treatment with praziquantel alone.

Combined mass treatment should have an important impact on schistosoma and hookworm prevalence and intensity and improves $\mathrm{Hb}$ levels.

\section{Risk of bias}

\begin{tabular}{|c|c|c|}
\hline Bias & Authors' judgement & Support for judgement \\
\hline $\begin{array}{l}\text { Random sequence genera- } \\
\text { tion (selection bias) }\end{array}$ & Low risk & $\begin{array}{l}\text { Randomized in one of four treatment groups, block design with block size of } \\
80 .\end{array}$ \\
\hline $\begin{array}{l}\text { Allocation concealment } \\
\text { (selection bias) }\end{array}$ & Low risk & $\begin{array}{l}\text { Randomization lists were prepared by WHO/TDR using a randomized block de- } \\
\text { sign. }\end{array}$ \\
\hline $\begin{array}{l}\text { Blinding of participants } \\
\text { and personnel (perfor- } \\
\text { mance bias) } \\
\text { All outcomes }\end{array}$ & Low risk & Double blind, placebo controlled; physically identical placebo. \\
\hline $\begin{array}{l}\text { Blinding of outcome as- } \\
\text { sessment (detection bias) } \\
\text { All outcomes }\end{array}$ & Unclear risk & Not mentioned. \\
\hline $\begin{array}{l}\text { Incomplete outcome data } \\
\text { (attrition bias) } \\
\text { All outcomes }\end{array}$ & Low risk & $\begin{array}{l}\text { Loss to follow-up } 10 \% \text { at six months, loss to follow-up } 17 \% \text { at one year (for all } \\
\text { groups). }\end{array}$ \\
\hline $\begin{array}{l}\text { Selective reporting (re- } \\
\text { porting bias) }\end{array}$ & High risk & $\mathrm{Hb}$ values, proteinuria, hematuria, ultrasound findings not reported. \\
\hline Other bias & Low risk & No evidence for other bias. \\
\hline
\end{tabular}

Omer 1981 SDN

\begin{tabular}{ll}
\hline Methods & RCT \\
& Diagnosis: sedimentation concentration technique, miracidial hatching \\
Follow-up at seven days, one month, three to four months, six months
\end{tabular}

\section{Participants}

Patients presenting to the Hospital of Tropical diseases, Karthoum, aged eight to 16 years

Number of patients randomized: 152

Inclusion: mixed S. haematobium and S. mansoni infections

Exclusion: under eight years of age, advanced stage of disease, severe anaemia, poor general health

Interventions
$\begin{aligned} & \text { 2. Praziquantel } 30 \mathrm{mg} / \mathrm{kg} \text { single dose } \\ & \text { 3. Praziquantel } 2 \times 20 \mathrm{mg} / \mathrm{kg} \text { within one day }\end{aligned}$


Omer 1981 SDN (Continued)

\section{Egg counts}

Adverse events

Laboratory parameters at day 0 or 1 and at day 1 or 2 , not of interest for this review

Lotes
Setting: Hospital of Tropical Diseases, Karthoum
Endemicity: not reported
Dates: 1978 to 1979
Funding: not reported
Authors' conclusion: Praziquantel is easily applicable, safe and effective in the treatment of mixed (S.
haematobium and S. mansoni) infections

\section{Risk of bias}

\begin{tabular}{|c|c|c|}
\hline Bias & Authors' judgement & Support for judgement \\
\hline $\begin{array}{l}\text { Random sequence genera- } \\
\text { tion (selection bias) }\end{array}$ & Unclear risk & Randomized. \\
\hline $\begin{array}{l}\text { Allocation concealment } \\
\text { (selection bias) }\end{array}$ & Unclear risk & Not mentioned. \\
\hline $\begin{array}{l}\text { Blinding of participants } \\
\text { and personnel (perfor- } \\
\text { mance bias) } \\
\text { All outcomes }\end{array}$ & Unclear risk & Single blind. \\
\hline $\begin{array}{l}\text { Blinding of outcome as- } \\
\text { sessment (detection bias) } \\
\text { All outcomes }\end{array}$ & Unclear risk & Not mentioned. \\
\hline $\begin{array}{l}\text { Incomplete outcome data } \\
\text { (attrition bias) } \\
\text { All outcomes }\end{array}$ & Unclear risk & Loss to follow-up at six months $17 \%$ to $22 \%$, balanced. \\
\hline $\begin{array}{l}\text { Selective reporting (re- } \\
\text { porting bias) }\end{array}$ & Low risk & No evidence of selective reporting. \\
\hline Other bias & Low risk & No evidence of other bias. \\
\hline
\end{tabular}

\section{Oyediran 1981 NGA}

Methods RCT

Diagnostics: collection of a midday urine sample (12.00 to 2.00), taking a $10 \mathrm{~mL}$ sub sample, filtration of the urine, staining with Ninhydrin, counting of the eggs retained on the filter paper

Follow-up at one, three and six months

\begin{tabular}{|c|c|}
\hline \multirow{2}{*}{ Participants } & Primary school children aged nine to 16 years \\
\hline & Participants randomized: 90 \\
\hline
\end{tabular}


Oyediran 1981 NGA (Continued)

Inclusion criteria: mean egg count 80 eggs $/ 10 \mathrm{~mL}$, viable eggs, aged over six years

Exclusion criteria: under six years, concurrent acute or serious illness, antischistosomal treatment within the past six months

\begin{tabular}{ll}
\hline Interventions & Praziquantel $30 \mathrm{mg} / \mathrm{kg}$ single dose \\
& Praziquantel $40 \mathrm{mg} / \mathrm{kg}$ single dose \\
& Praziquantel $2 \times 20 \mathrm{mg} / \mathrm{kg}$, dose interval three to four hours \\
& Placebo \\
\hline Outcomes & Egg counts \\
\hline Notes & Nigeria, Oyo State \\
& Setting: Primary Schools \\
& Dates: not reported \\
& Funding: not reported \\
& Authors' conclusion: No significant difference in efficacy between the three dosage regimens, trials on \\
the effects of lower doses required.
\end{tabular}

\section{Risk of bias}

\begin{tabular}{|c|c|c|}
\hline Bias & Authors' judgement & Support for judgement \\
\hline $\begin{array}{l}\text { Random sequence genera- } \\
\text { tion (selection bias) }\end{array}$ & Low risk & Table of random numbers. \\
\hline $\begin{array}{l}\text { Allocation concealment } \\
\text { (selection bias) }\end{array}$ & Unclear risk & Not mentioned. \\
\hline $\begin{array}{l}\text { Blinding of participants } \\
\text { and personnel (perfor- } \\
\text { mance bias) } \\
\text { All outcomes }\end{array}$ & Unclear risk & $\begin{array}{l}\text { Placebo single dose } \\
\text { The treatment group received a split dose of praziquantel, blinding not men- } \\
\text { tioned. }\end{array}$ \\
\hline $\begin{array}{l}\text { Blinding of outcome as- } \\
\text { sessment (detection bias) } \\
\text { All outcomes }\end{array}$ & Unclear risk & Not mentioned. \\
\hline $\begin{array}{l}\text { Incomplete outcome data } \\
\text { (attrition bias) } \\
\text { All outcomes }\end{array}$ & High risk & $\begin{array}{l}\text { High loss to follow-up, not balanced (at one month } 4 \text { to } 17 \% \text {, at three months } \\
17 \text { to } 23 \% \text {, at six month } 26 \text { to } 38 \% \text {, at twelve months } 76 \% \text { to } 87 \% \text { ). }\end{array}$ \\
\hline $\begin{array}{l}\text { Selective reporting (re- } \\
\text { porting bias) }\end{array}$ & Low risk & No evidence of selective reporting. \\
\hline Other bias & Low risk & No evidence of other bias. \\
\hline
\end{tabular}

\section{Pugh 1983 MWI}

Methods RCT


Pugh 1983 MWI (Continued)

Diagnostics: collection of two midday urine samples on two consecutive days filtration, staining and egg count

Follow-up at one, three and six months. Further follow-up reported at nine, 12, 15 and 24 months in a separate publication (Pugh $1983 \mathrm{MWI}$ )

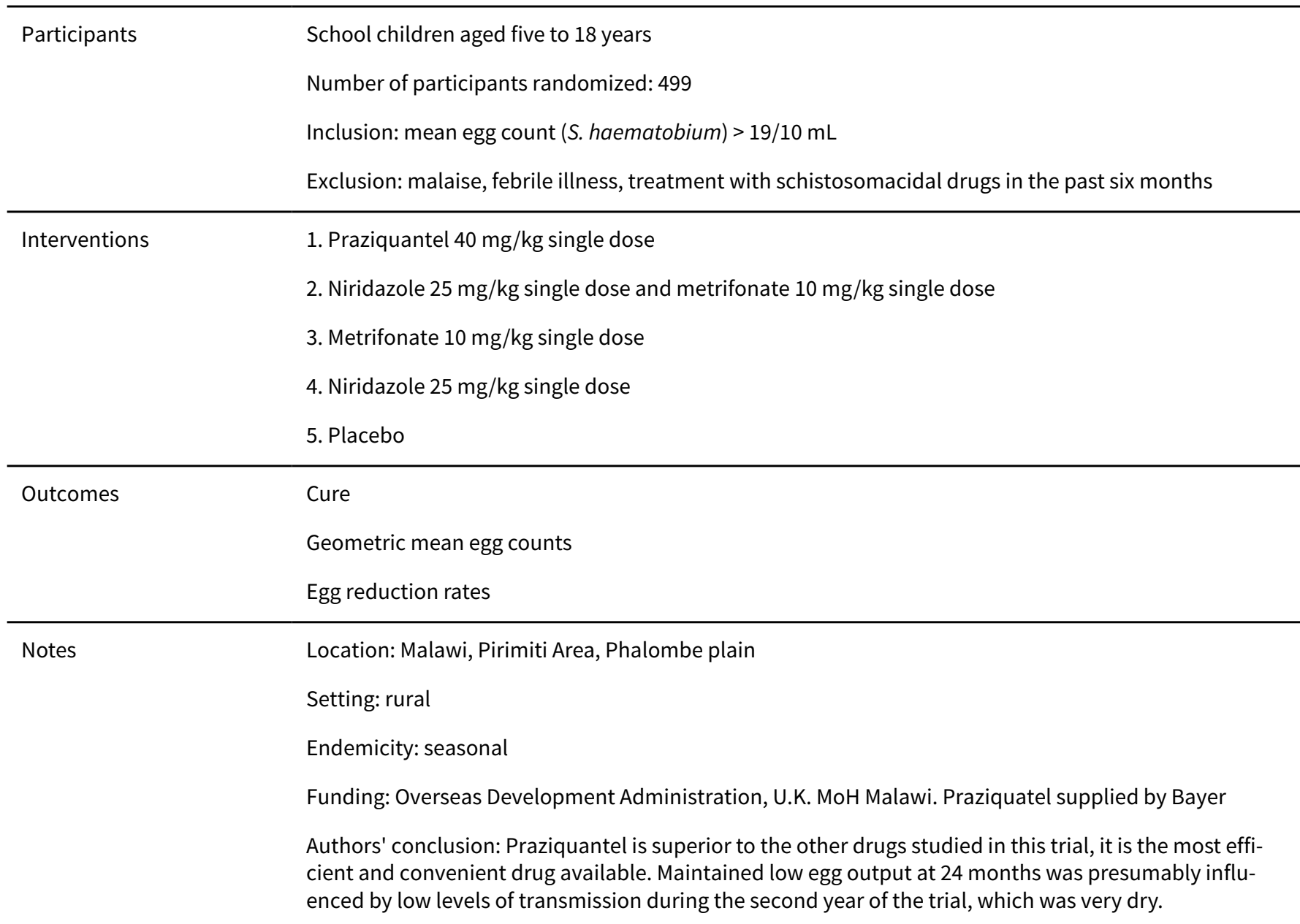

\section{Risk of bias}

\begin{tabular}{lll}
\hline Bias & Authors' judgement & Support for judgement \\
\hline $\begin{array}{l}\text { Random sequence genera- } \\
\text { tion (selection bias) }\end{array}$ & Low risk & Use of a randomized x-y list. \\
\hline $\begin{array}{l}\text { Allocation concealment } \\
\text { (selection bias) }\end{array}$ & Low risk & $\begin{array}{l}\text { "An independent worker had sole and confidential access to a randomised x-y } \\
\text { list." }\end{array}$ \\
\hline $\begin{array}{l}\text { Blinding of participants } \\
\text { and personnel (perfor- } \\
\text { mance bias) }\end{array}$ & Low risk & Described as double blind. \\
$\begin{array}{l}\text { All outcomes } \\
\text { Blinding of outcome as- } \\
\text { sessment (detection bias) } \\
\begin{array}{l}\text { All outcomes } \\
\end{array}\end{array}$ & Unclear risk & Not mentioned. \\
\hline
\end{tabular}


Pugh 1983 MWI (Continued)

Incomplete outcome data Unclear risk Loss to follow-up low at one months: $0 \%$ to $4.1 \%$, at three months $8 \%$ to $11 \%$ (attrition bias)

All outcomes in treatment groups, up to $23 \%$ in the placebo group; at six months $20 \%$ in the treatment group. Loss to follow-up high at 24 months, about $40 \%$ to $70 \%$.

\begin{tabular}{|c|c|c|}
\hline $\begin{array}{l}\text { Selective reporting (re- } \\
\text { porting bias) }\end{array}$ & Low risk & No evidence of selective reporting. \\
\hline Other bias & High risk & $\begin{array}{l}\text { Baseline imbalance in terms of intensity of infection. } \\
\text { "In accordance to with local ethical guidelines the placebo group consisted } \\
\text { only of children with light ( } 20-124 \text { ova/10mL or moderate (125 to } 4999 \text { ova/10 } \\
\mathrm{mL} \text { ) infections before treatment. Important baseline characteristics not re- } \\
\text { ported (age, weight). }\end{array}$ \\
\hline
\end{tabular}

\section{Rey 1983 NER}

Methods
Diagnostics: collection of two urine samples, filtration (Swinex 13 Filter Millipore, 13 mm diameter), fix-
ation and staining (Lugol), egg counts
Length of follow-up: one, three and six months

Participants: recruits aged 18 to 20 years and college students aged 15 to 19 years
Number of participants randomized: 207
(co-infection with S. mansoni likely, but not investigated)
Inclusion: S. haematobium positive
Exclusion: not reported

$\begin{array}{ll}\text { Interventions } & \text { 1. Praziquantel } 30 \mathrm{mg} / \mathrm{kg} \text { daily dose } \\ \text { 2. Praziquantel } 40 \mathrm{mg} / \mathrm{kg} \text { daily dose } \\ \text { 3. Oltipraz } 17.5 \mathrm{mg} / \mathrm{kg} 2 \times \text { daily in one day }\end{array}$

\begin{tabular}{ll}
\hline Outcomes & Failure \\
& Egg reduction rates \\
\hline Notes & Location: Niger \\
& Setting: not reported \\
& Endemicity: not reported \\
& Dates: not reported \\
& Funding: not reported \\
& Authors' conclusion: No significant difference found between praziquantel $30 \mathrm{mg} / \mathrm{kg}$ and praziquantel \\
& $40 \mathrm{mg} / \mathrm{kg}$.
\end{tabular}

\section{Risk of bias}

Bias Authors' judgement Support for judgement


Rey 1983 NER (Continued)

\begin{tabular}{|c|c|c|}
\hline Random sequence genera- & Low risk & Randomized, tirage au sort. \\
\hline
\end{tabular}

Allocation concealment $\quad$ Unclear risk Not mentioned.
(selection bias)

(selection bias)

Blinding of participants Unclear risk Not mentioned, no use of placebo.
and personnel (perfor-
mance bias)
All outcomes

\begin{tabular}{|c|c|c|}
\hline $\begin{array}{l}\text { Blinding of outcome as- } \\
\text { sessment (detection bias) } \\
\text { All outcomes }\end{array}$ & Unclear risk & Not mentioned. \\
\hline $\begin{array}{l}\text { Incomplete outcome data } \\
\text { (attrition bias) } \\
\text { All outcomes }\end{array}$ & Unclear risk & $\begin{array}{l}\text { Loss to follow-up acceptable at one month ( } 9 \% \text { to } 15 \% \text { ) and three months } 9 \% \\
\text { to } 11 \% \text {, high at six months ( } 39 \% \text { to } 47 \%) \text {. }\end{array}$ \\
\hline $\begin{array}{l}\text { Selective reporting (re- } \\
\text { porting bias) }\end{array}$ & Low risk & No evidence of selective reporting. \\
\hline Other bias & Low risk & Baseline characteristics not reported. \\
\hline
\end{tabular}

\section{Rey 1984 NER}

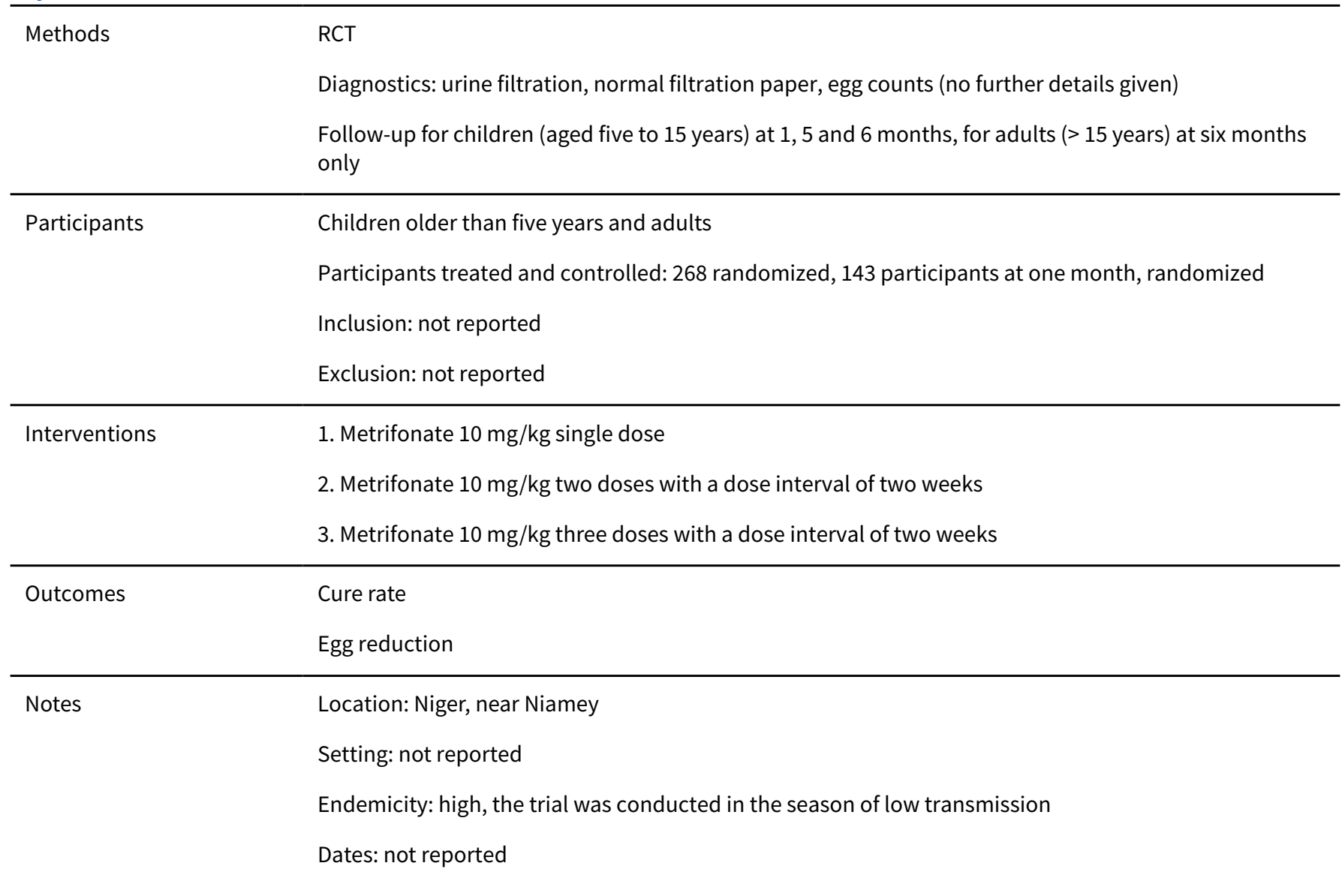


Rey 1984 NER (Continued)

Funding: not reported

Authors' conclusions: Recommendation against the combined metrifonate niridazole treatment.

\section{Risk of bias}

\begin{tabular}{lll}
\hline Bias & Authors' judgement & Support for judgement \\
\hline $\begin{array}{l}\text { Random sequence genera- } \\
\text { tion (selection bias) }\end{array}$ & Low risk & "au hasard ", random number table.
\end{tabular}

tion (selection bias)

\begin{tabular}{lll}
\hline $\begin{array}{l}\text { Allocation concealment } \\
\text { (selection bias) }\end{array}$ & Unclear risk & No comment.
\end{tabular}

Blinding of participants Unclear risk No comment.
and personnel (performance bias)

All outcomes

\begin{tabular}{lll}
\hline $\begin{array}{l}\text { Blinding of outcome as- } \\
\text { sessment (detection bias) } \\
\text { All outcomes }\end{array}$ & Unclear risk & No comment. \\
\hline $\begin{array}{l}\text { Incomplete outcome data } \\
\text { (attrition bias) } \\
\text { All outcomes }\end{array}$ & High risk & Loss to follow-up high: at one month 50\%, at four months 39\%. \\
\hline $\begin{array}{l}\text { Selective reporting (re- } \\
\text { porting bias) }\end{array}$ & Low risk & No evidence of selective reporting. \\
\hline Other bias & Low risk & No evidence of other bias, funding not stated. \\
\hline
\end{tabular}

Sacko 2009 MLI

$\begin{array}{ll}\text { Methods } & \text { RCT } \\ \text { Diagnostics: Collection of three urine samples between } 10 \text { am and } 2 \text { PM on three consecutive days. } 10 \\ \mathrm{~mL} \text { of urine passed through a nucleopore filter, Swinnex filter support. Egg counts. } \\ \text { Follow-up at 3, } 6 \text { and } 18 \text { months }\end{array}$

\begin{tabular}{ll}
\hline Participants & School children aged seven to 14 years \\
& Number of participants randomized: 603 \\
& Inclusion: not reported \\
& Exclusion: not reported \\
\hline Interventions & Praziquantel $40 \mathrm{mg} / \mathrm{kg}$ single dose \\
& Praziquantel $40 \mathrm{mg} / \mathrm{kg}$ two doses, interval two weeks \\
\hline Outcomes & Cure rate \\
Egg reduction \\
Haematuria
\end{tabular}


Sacko 2009 MLI (Continued)

Notes
Location: Mali, Niger River Basin

Setting: rural, primary schools

Endemicity: not reported

Dates: not reported

Funding: not reported

Authors' conclusion: Significantly reduced prevalence of microhematuria with praziquantel $x 2$, this could indicate reduction of morbidity

\section{Risk of bias}

\begin{tabular}{|c|c|c|}
\hline Bias & Authors' judgement & Support for judgement \\
\hline $\begin{array}{l}\text { Random sequence genera- } \\
\text { tion (selection bias) }\end{array}$ & Low risk & Randomized (SPSS generated random number tables). \\
\hline $\begin{array}{l}\text { Allocation concealment } \\
\text { (selection bias) }\end{array}$ & Low risk & Not mentioned. \\
\hline $\begin{array}{l}\text { Blinding of participants } \\
\text { and personnel (perfor- } \\
\text { mance bias) } \\
\text { All outcomes }\end{array}$ & Low risk & $\begin{array}{l}\text { Double blind, placebo-controlled. } \\
\text { Placebo tablets were of the same form and colour as praziquantel. }\end{array}$ \\
\hline $\begin{array}{l}\text { Blinding of outcome as- } \\
\text { sessment (detection bias) } \\
\text { All outcomes }\end{array}$ & Unclear risk & Not mentioned. \\
\hline $\begin{array}{l}\text { Incomplete outcome data } \\
\text { (attrition bias) } \\
\text { All outcomes }\end{array}$ & Unclear risk & $\begin{array}{l}\text { Loss to follow-up unclear, as number randomized were not reported, only the } \\
\text { numbers at first follow-up at three months. }\end{array}$ \\
\hline $\begin{array}{l}\text { Selective reporting (re- } \\
\text { porting bias) }\end{array}$ & Low risk & Follow-up data at six and 18 months reported in graphs, not in numbers. \\
\hline Other bias & Low risk & No evidence for other bias. \\
\hline
\end{tabular}

\section{Stephenson 1985 KEN}

$\begin{array}{ll}\text { Methods } & \text { RCT } \\ & \text { Diagnostics: nucleopore filter method of Peters and others } \\ \text { collection of a midday urine sample (complete bladder content, } 11.00 \text { to } 12.00 \text { ) after } 200 \mathrm{~mL} \text { of fruit } \\ \text { drink, nucleopore filter method of Peters and others, staining with } 0.5 \text { trypan blue, egg counts in } 10 \mathrm{~mL} \\ \text { of urine adjusted for the total volume of each urine specimen } \\ \text { Follow-up for six months }\end{array}$

Participants

Primary school children aged six to 16 years

Number of participants randomized: 400

Inclusion: light to moderate S. haematobium infections at exam 1 
Stephenson 1985 KEN (Continued)

$$
\text { Exclusion: not reported }
$$

Interventions $\quad$ 1. Metrifonate $7.5 \mathrm{mg} / \mathrm{kg}$ three doses, dose interval one to two weeks

2. Placebo: gelatin capsules

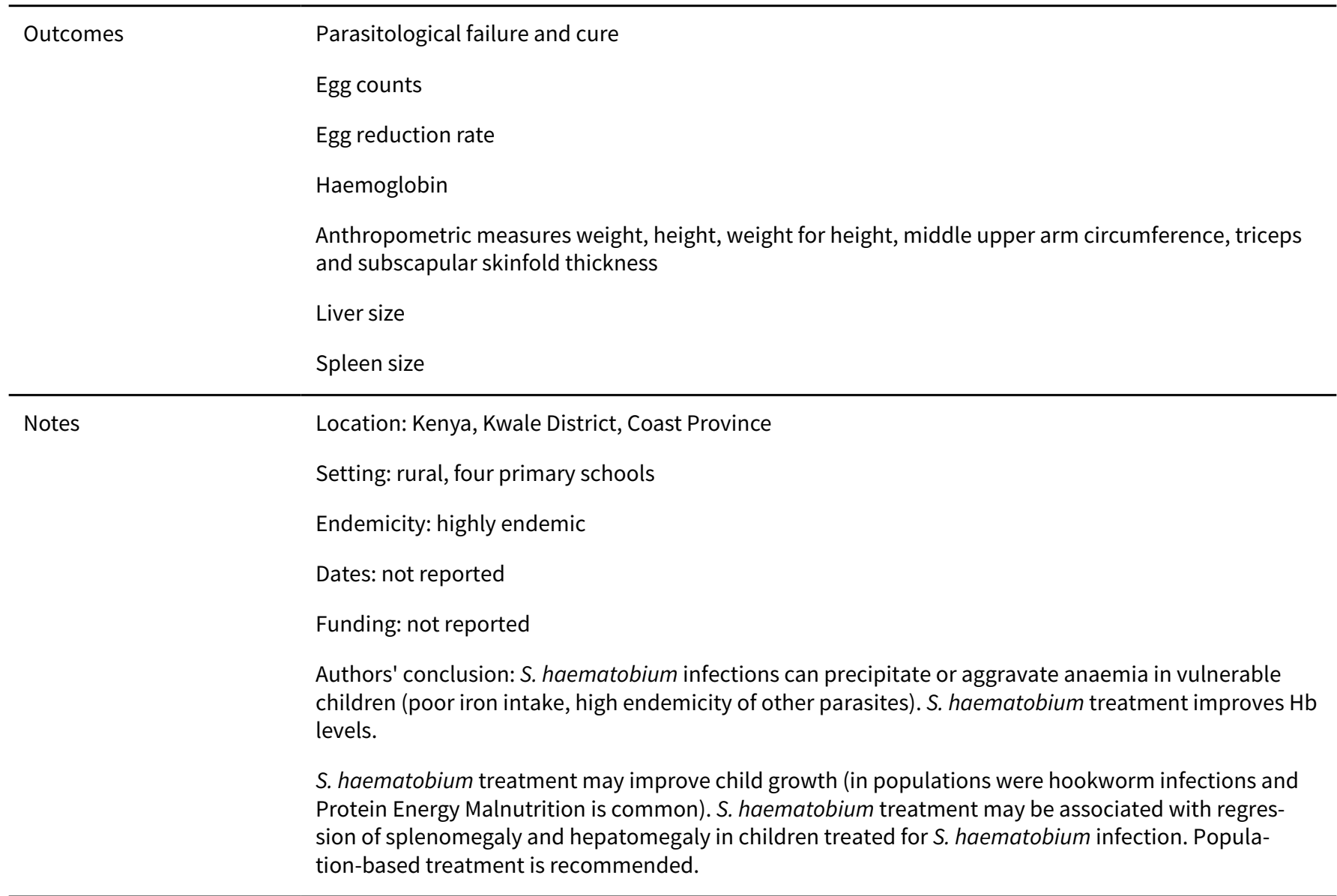

\section{Risk of bias}

\begin{tabular}{lll} 
Bias & Authors' judgement & Support for judgement \\
\hline $\begin{array}{l}\text { Random sequence genera- } \\
\text { tion (selection bias) }\end{array}$ & Unclear risk & Allocated at random. \\
\hline $\begin{array}{l}\text { Allocation concealment } \\
\text { (selection bias) }\end{array}$ & Unclear risk & Not described. \\
\hline $\begin{array}{l}\text { Blinding of participants } \\
\begin{array}{l}\text { and personnel (perfor- } \\
\text { mance bias) } \\
\text { All outcomes }\end{array}\end{array}$ & Low risk & Use of placebo. \\
\hline
\end{tabular}

\begin{tabular}{lll}
\hline $\begin{array}{l}\text { Blinding of outcome as- } \\
\text { sessment (detection bias) } \\
\text { All outcomes }\end{array}$ & Low risk & $\begin{array}{l}\text { Examinations } 1 \text { and } 2 \text { were carried out in a blind fashion with the same team of } \\
\text { workers. }\end{array}$ \\
\hline $\begin{array}{l}\text { Incomplete outcome data } \\
\text { (attrition bias) } \\
\text { All outcomes }\end{array}$ & Lnclear risk & \\
\hline \hline
\end{tabular}

Drugs for treating urinary schistosomiasis (Review)

Copyright (c) 2014 The Authors. Cochrane Database of Systematic Reviews published by John Wiley \& Sons, Ltd. on behalf of The Cochrane

Collaboration. 
Stephenson 1985 KEN (Continued)

Selective reporting (re- Low risk No evidence of selective outcome reporting.
porting bias)

Other bias Low risk No evidence of other sources of bias.

\section{Stephenson 1989 KEN}

\begin{tabular}{|c|c|}
\hline \multirow[t]{4}{*}{ Methods } & RCT \\
\hline & $\begin{array}{l}\text { Diagnostics: collection of a midday urine sample (complete bladder content, } 11.00 \text { to } 12.00 \text { ) after } 200 \\
\mathrm{~mL} \text { of fruit drink, nucleotome filter method of Peters and others, staining with } 0.5 \text { trypan blue, egg } \\
\text { counts in } 10 \mathrm{~mL} \text { of urine adjusted for the total volume of each urine specimen }\end{array}$ \\
\hline & Follow-up at eight months (as only time point) \\
\hline & $\begin{array}{l}\text { Latham 1990, a sub-study nested within Stephenson } 1989 \text { KEN, followed up patients at five weeks (as } \\
\text { only time point) }\end{array}$ \\
\hline \multirow[t]{6}{*}{ Participants } & Primary school children, $98 \%$ Muslim of the Wadigo tribe, aged eight to 13 years \\
\hline & Number of participants randomized: not reported \\
\hline & Number of participants analysed: 312 \\
\hline & Inclusion: light to moderate infections \\
\hline & Exclusion: anaemia ( $\mathrm{Hb}<8 \mathrm{G} / \mathrm{dL}$, severe infections) \\
\hline & $\begin{array}{l}\text { Latham } 1990 \text { included } 48 \text { boys aged seven to } 15 \text { years with no sign of puberty, high egg counts, } \mathrm{Hb}>8 \\
\mathrm{G} / \mathrm{dL} \text {, cooperation for physical fitness test }\end{array}$ \\
\hline \multirow[t]{4}{*}{ Interventions } & 1. Praziquantel $40 \mathrm{mg} / \mathrm{kg}$ single dose \\
\hline & 2. Metrifonate $10 \mathrm{mg} / \mathrm{kg}$ single dose \\
\hline & 3. Placebo \\
\hline & As a nested study, Latham had the same study arms. \\
\hline \multirow[t]{10}{*}{ Outcomes } & Parasitological failure \\
\hline & Egg counts (geometric and arithmetic) \\
\hline & $\begin{array}{l}\text { Anthropometric measurements: weight, height, MUAC, triceps skinfold thickness, subscapular skinfold } \\
\text { thickness, }\end{array}$ \\
\hline & Haemoglobin \\
\hline & Liver size \\
\hline & Spleen size \\
\hline & $\begin{array}{l}\text { Latham } 1990 \text { (reference see Stephenson } 1989 \text { KEN) reports parasitological failure, egg reduction rate } \\
\text { and anthropometric measures: weight, height, skinfold thickness, MUAC at five weeks at five weeks, } \\
\text { and additionally reports on }\end{array}$ \\
\hline & Physical fitness: Harvard Step test, \\
\hline & Appetite (quantity of porridge consumed) \\
\hline & Questionnaire of clinical symptoms \\
\hline
\end{tabular}

Drugs for treating urinary schistosomiasis (Review) 
Stephenson 1989 KEN (Continued)

Notes

Location: Kenya, Kwale district, Coast Province

Setting: rural, primary schools

Endemicity: endemic for S. haematobium, hookworm and malaria

Dates: March 1986 to April 1986

Funding: Edna McConnell Clark Foundation, grant 284-0120

Authors' conclusion: Both metrifonate and praziquantel are effective in reducing egg excretion and are both recommended for population based treatment. Praziquantel is more effective. S. haematobium treatment with a single dose of either metrifonate or praziquantel may improve child growth in areas were hookworms and malnutrition are common and appears to have a beneficial effect on hepatomegaly and splenomegaly.

Treatment of moderate to heavy S. haematobium infections with metrifonate or praziquantel in undernourished schoolboys can improve physical fitness, growth rates and appetite within approximately one month.

Recommendation for widespread population based chemotherapy in highly endemic areas as Kwale district.

\section{Risk of bias}

\begin{tabular}{|c|c|c|}
\hline Bias & Authors' judgement & Support for judgement \\
\hline $\begin{array}{l}\text { Random sequence genera- } \\
\text { tion (selection bias) }\end{array}$ & Unclear risk & Allocated at random. \\
\hline $\begin{array}{l}\text { Allocation concealment } \\
\text { (selection bias) }\end{array}$ & Unclear risk & Not mentioned. \\
\hline $\begin{array}{l}\text { Blinding of participants } \\
\text { and personnel (perfor- } \\
\text { mance bias) } \\
\text { All outcomes }\end{array}$ & Low risk & Use of placebo. \\
\hline $\begin{array}{l}\text { Blinding of outcome as- } \\
\text { sessment (detection bias) } \\
\text { All outcomes }\end{array}$ & Low risk & Examinations carried out in a blind fashion. \\
\hline $\begin{array}{l}\text { Incomplete outcome data } \\
\text { (attrition bias) } \\
\text { All outcomes }\end{array}$ & Low risk & Loss to follow-up 10\%, 3 participants not accounted for. \\
\hline $\begin{array}{l}\text { Selective reporting (re- } \\
\text { porting bias) }\end{array}$ & Low risk & No evidence of selective reporting. \\
\hline Other bias & Low risk & No evidence for other source of bias. \\
\hline
\end{tabular}

Taylor 1988 ZWE

$\begin{array}{ll}\text { Methods } & \text { RCT } \\ & \text { Diagnostics: urine sample collection; three midday urine samples (10.00 to 14.00), filtration (13 mm } \\ \text { nytrl filter), staining with Lugol }\end{array}$


Taylor 1988 ZWE (Continued)

Follow-up at 1, 3 and 6 months

Participants
Number of participants randomized: 373
Inclusion: mixed S. haematobium and S. mansoni infection
Exclusion: not reported

\begin{tabular}{|c|c|}
\hline \multirow[t]{5}{*}{ Interventions } & 1. Praziquantel $10 \mathrm{mg} / \mathrm{kg}$ single dose \\
\hline & 2. Praziquantel $20 \mathrm{mg} / \mathrm{kg}$ single dose \\
\hline & 3. Praziquantel $30 \mathrm{mg} / \mathrm{kg}$ single dose \\
\hline & 4. Praziquantel $40 \mathrm{mg} / \mathrm{kg}$ single dose \\
\hline & 4. Control: Nil \\
\hline
\end{tabular}

\begin{tabular}{ll}
\hline Outcomes & Parasitological cure \\
& Egg count \\
\hline Notes & Location: Zimbabwe \\
& Setting rural, primary school \\
& Endemicity: seasonal transmission \\
& Date: not reported \\
& Funding: Rockefeller Foundation (financial support) \\
& Authors' conclusion: Doses of 20 to 40 mg praziquantel may be equally effective in S. haematobium in- \\
fection
\end{tabular}

\section{Risk of bias}

\begin{tabular}{lll}
\hline Bias & Authors' judgement & Support for judgement \\
\hline $\begin{array}{l}\text { Random sequence genera- } \\
\text { tion (selection bias) }\end{array}$ & Unclear risk & Randomly assigned. \\
\hline $\begin{array}{l}\text { Allocation concealment } \\
\text { (selection bias) }\end{array}$ & Unclear risk & Not mentioned. \\
\hline $\begin{array}{l}\text { Blinding of participants } \\
\text { and personnel (perfor- } \\
\text { mance bias) }\end{array}$ & Low risk & Single blind manner "only the principal investigator knew which children had \\
$\begin{array}{l}\text { All outcomes } \\
\text { Blinding of outcome as- } \\
\text { sessment (detection bias) } \\
\text { All outcomes }\end{array}$ & Unclear risk & been assigned to which treatment group." \\
\hline $\begin{array}{l}\text { Incomplete outcome data } \\
\text { (attrition bias) } \\
\begin{array}{l}\text { All outcomes } \\
\hline\end{array}\end{array}$ & Unclear risk & Not mentioned. \\
\hline
\end{tabular}


Taylor 1988 ZWE (Continued)

Selective reporting (re- Low risk Novidence of selective reporting.
porting bias)

Other bias Low risk No evidence for other source of bias.

Tchuente 2004 CMR

\begin{tabular}{ll}
\hline Methods & RCT \\
& $\begin{array}{l}\text { Diagnostics: collection of two urine samples on two consecutive days in } 50 \mathrm{~mL} \text { plastic screw cap vials, } \\
\text { processing in field laboratory, agitation of urine (from dispersal of eggs) filtration of } 10 \mathrm{~mL} \text { (Nucleopore } \\
\text { filter), egg counts } \\
\text { Length of follow-up 3, } 6 \text { and } 9 \text { weeks }\end{array}$ \\
\hline Participants & School children, age not reported \\
& Inclusion: $S$. haematobium positive \\
& Exclusion: not reported
\end{tabular}

Interventions
1. Praziquantel $40 \mathrm{mg} / \mathrm{kg}$ single dose
2. Praziquantel $40 \mathrm{mg} / \mathrm{kg}$ two single doses, dose interval three weeks
3. Praziquantel $40 \mathrm{mg} / \mathrm{kg}$ three single doses, dose interval three weeks

\begin{tabular}{ll}
\hline Outcomes & Cure rates \\
Egg counts, egg reduction rates \\
Proteinuria \\
\hline Lotes \\
Setting: urban, schools \\
Date: April to June 2002 \\
Endemicity: endemic all year, prevalence amongst school children 41.8\%, trial carried out during high \\
transmission period \\
Funding: European Commission INCO-DC (ICA-4-CT-2001-10079) \\
Authors' conclusion: No significant differences between the three dosing regimens, persistent high cure \\
rates with a single dose of Praziquantel. Findings suggest efficacy of praziquantel against immature \\
schistosoma stages.
\end{tabular}

\section{Risk of bias}

\begin{tabular}{lll}
\hline Bias & Authors' judgement & Support for judgement \\
\hline $\begin{array}{l}\text { Random sequence genera- } \\
\text { tion (selection bias) }\end{array}$ & Unclear risk & Assigned to random groups. \\
\hline $\begin{array}{l}\text { Allocation concealment } \\
\text { (selection bias) }\end{array}$ & Unclear risk & Not mentioned. \\
\hline \hline
\end{tabular}


Tchuente 2004 CMR (Continued)

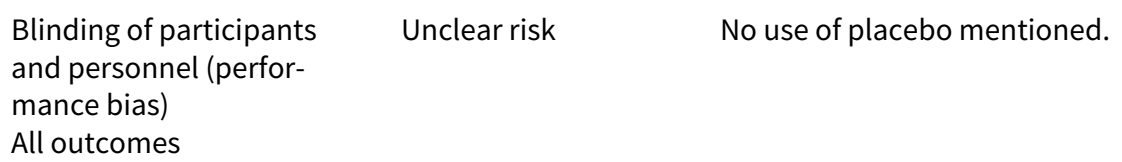

Blinding of outcome as- Unclear risk Not mentioned.
sessment (detection bias) All outcomes

Incomplete outcome data High risk (attrition bias)

All outcomes

Selective reporting (re- Low risk No evidence of selective reporting.
porting bias)

Other bias Low risk No evidence of other bias.

van den Biggelaar $02 \mathrm{GAB}$

\begin{tabular}{ll}
\hline Methods & RCT \\
& $\begin{array}{l}\text { Diagnostics: collection of urine samples on three different days, filtration of } 10 \mathrm{~mL} \text { urine, nucleopore } \\
\text { pore size } 13 \mu \mathrm{m}) \text {, staining with ninhydrin, eggs count }\end{array}$ \\
& Follow-up at two and three years, length of follow-up three years
\end{tabular}

\begin{tabular}{|c|c|}
\hline \multirow[t]{4}{*}{ Participants } & School children aged five to 14 years \\
\hline & Participants randomized: 135 \\
\hline & Inclusion: positive for S. haematobium eggs \\
\hline & Exclusion: not reported \\
\hline \multirow[t]{2}{*}{ Interventions } & Praziquantel $40 \mathrm{mg} / \mathrm{kg}$ single dose \\
\hline & Praziquantel $40 \mathrm{mg} / \mathrm{kg}$ in repeated doses, dose interval three months, over two years \\
\hline \multirow[t]{3}{*}{ Outcomes } & Cure rates, failure rates \\
\hline & Egg counts \\
\hline & Microhaematuria \\
\hline \multirow[t]{6}{*}{ Notes } & Location: Gaboon, near Lambarene \\
\hline & Setting: rural, village schools \\
\hline & Endemicity: high \\
\hline & Funding: not reported \\
\hline & Dates: not reported \\
\hline & $\begin{array}{l}\text { Authors' conclusion: relate to immunologic outcomes also measured by this trial, but not of interest for } \\
\text { this review }\end{array}$ \\
\hline
\end{tabular}

\section{Risk of bias}

Drugs for treating urinary schistosomiasis (Review)

Copyright (c) 2014 The Authors. Cochrane Database of Systematic Reviews published by John Wiley \& Sons, Ltd. on behalf of The Cochrane

Collaboration. 
van den Biggelaar 02 GAB (Continued)

\begin{tabular}{|c|c|c|}
\hline Bias & Authors' judgement & Support for judgement \\
\hline $\begin{array}{l}\text { Random sequence genera- } \\
\text { tion (selection bias) }\end{array}$ & Unclear risk & Allocated randomly. \\
\hline $\begin{array}{l}\text { Allocation concealment } \\
\text { (selection bias) }\end{array}$ & High risk & "The allocation of children to the treatment group was open." \\
\hline $\begin{array}{l}\text { Blinding of participants } \\
\text { and personnel (perfor- } \\
\text { mance bias) } \\
\text { All outcomes }\end{array}$ & Unclear risk & Use of placebo (given every three months) not mentioned. \\
\hline $\begin{array}{l}\text { Blinding of outcome as- } \\
\text { sessment (detection bias) } \\
\text { All outcomes }\end{array}$ & Unclear risk & Not mentioned. \\
\hline $\begin{array}{l}\text { Incomplete outcome data } \\
\text { (attrition bias) } \\
\text { All outcomes }\end{array}$ & High risk & $\begin{array}{l}\text { High loss to follow-up (not balanced, reasons not given): } \\
\text { at } 24 \text { months } 8 \%, 23 \%, 44 \% \text { in different treatment groups; } \\
\text { at } 36 \text { months } 40 \%, 64 \%, 77 \% \text {. }\end{array}$ \\
\hline $\begin{array}{l}\text { Selective reporting (re- } \\
\text { porting bias) }\end{array}$ & Low risk & No evidence of selective reporting. \\
\hline Other bias & Low risk & No evidence of other bias. \\
\hline
\end{tabular}

\section{Wilkins 1987 GMB}

\begin{tabular}{|c|c|}
\hline \multirow[t]{3}{*}{ Methods } & $\mathrm{RCT}$ \\
\hline & Diagnostics: \\
\hline & Follow-up at two to three months \\
\hline \multirow[t]{2}{*}{ Participants } & Residents aged two to 19 years, median age 9.5 years \\
\hline & Participants randomized: not reported \\
\hline \multirow[t]{5}{*}{ Interventions } & 1. Praziquantel $10 \mathrm{mg} / \mathrm{kg}$ \\
\hline & 2. Praziquantel $20 \mathrm{mg} / \mathrm{kg}$ \\
\hline & 3. Praziquantel $40 \mathrm{mg} / \mathrm{kg}$ \\
\hline & 4. Metrifonate $10 \mathrm{mg} / \mathrm{kg}$ \\
\hline & 5. Praziquantel $10 \mathrm{mg} / \mathrm{kg}$ and metrifonate $10 \mathrm{mg} / \mathrm{kg}$ \\
\hline \multirow[t]{2}{*}{ Outcomes } & Egg counts \\
\hline & Side effects \\
\hline \multirow[t]{3}{*}{ Notes } & Location: Gambia Upper River Division, Nyanamari \\
\hline & Setting: rural \\
\hline & Endemicity: seasonal, trial conducted during season of low transmission \\
\hline
\end{tabular}

Drugs for treating urinary schistosomiasis (Review) 
Wilkins 1987 GMB (Continued)

Dates: not reported

Funding: not reported

Authors' conclusion: Mass treatment of intensely infected groups should be based on the standard dose of praziquantel, with metrifonate as second choice.

Note: only one of the two trials reported in this publication, the Nyanamari trial, fulfilled the inclusion criteria.

\section{Risk of bias}

\section{Bias Authors' judgement Support for judgement}

Random sequence genera- Low risk "Subjects...were stratified into four age groups and within each age stratum tion (selection bias) were ordered by intensity of egg counts. They were then placed sequentially into groups of five. Computer generated random sets of the numbers one to five were used to allocated on subject in each group of five to each of the five regimens used."

Allocation concealment Unclear risk Not mentioned.

(selection bias)

Blinding of participants Unclear risk Placebo and blinding not mentioned.

and personnel (perfor-

mance bias)

All outcomes

\begin{tabular}{lll}
\hline $\begin{array}{l}\text { Blinding of outcome as- } \\
\text { sessment (detection bias) } \\
\text { All outcomes }\end{array}$ & Unclear risk & Not mentioned. \\
\hline $\begin{array}{l}\text { Incomplete outcome data } \\
\begin{array}{l}\text { (attrition bias) } \\
\text { All outcomes }\end{array}\end{array}$ & Unclear risk & Loss to follow-up unclear, as cure rates are reported as percentages. \\
\hline $\begin{array}{l}\text { Selective reporting (re- } \\
\text { porting bias) }\end{array}$ & Low risk & No evidence of selective reporting. \\
\hline Other bias & Low risk & Baseline characteristics not reported. \\
\hline
\end{tabular}

\section{Characteristics of excluded studies [ordered by study ID]}

\begin{tabular}{ll}
\hline Study & Reason for exclusion \\
\hline Aryeetey 1999 & Study of health education and community participation. \\
\hline Ayoya 2007 & $\begin{array}{l}\text { No comparison group (treatment groups receive praziquantel with or without iron supplements } \\
\text { and multivitamins). }\end{array}$ \\
\hline Bausch 1995 & Not a RCT. \\
\hline Beasley 1999 & $\begin{array}{l}\text { This study compares a combination of praziquantel and albendazole with placebo. This outcome is } \\
\text { not of interest for this review. }\end{array}$ \\
\hline Bejon 2008 & Study of gastrointestinal helminths, not urinary schistosomiasis. \\
\hline \hline
\end{tabular}

Drugs for treating urinary schistosomiasis (Review)

Copyright $\odot 2014$ The Authors. Cochrane Database of Systematic Reviews published by John Wiley \& Sons, Ltd. on behalf of The Cochrane

Collaboration. 


Study Reason for exclusion

Bhargava 2003

This study does not report baseline criteria for control group, as the control group was not screened at baseline.

\section{Boulanger 2007}

Burchard 1984

No comparison group (both groups receive artesunate).

This study compares praziquantel $2 \times 30 \mathrm{mg} / \mathrm{kg}$ to oltipraz, which is obsolete. Details of this trial can be seen in earlier versions of this review.

\begin{tabular}{ll} 
Clarke 1969 & Not a RCT. \\
\hline Clarke 1973 & $\begin{array}{l}\text { Not a RCT, allotted to groups, "for practical reasons, the infected children in the two senior grades } \\
\text { were set aside for treatment with i.m. hycanthone". }\end{array}$ \\
\hline Creasey 1986 & $\begin{array}{l}\text { This study compares different doses of praziquantel }(8 \mathrm{mg} / \mathrm{kg}, 15 \mathrm{mg} / \mathrm{kg} \text { and } 20 \mathrm{mg} / \mathrm{kg}) \mathrm{combined} \\
\text { with oxaminique in patients with } S \text {. haematobium and } \mathrm{S} \text {. mansoni co-infections. A comparison of } \\
\text { the praziquantel dosages used is not of interest for this review. }\end{array}$
\end{tabular}

\begin{tabular}{ll}
\hline Danso-Appiah 2009 & Systematic review. \\
\hline Davis 1966 & $\begin{array}{l}\text { This study evaluates different doses of ambilhar which is now obsolete. Details of this trial can be } \\
\text { seen in earlier versions of this review. }\end{array}$ \\
\hline
\end{tabular}

\begin{tabular}{|c|c|}
\hline Davis 1979 & $\begin{array}{l}\text { Outcomes are not reported per treatment group, only for the total number of participants random- } \\
\text { ized. }\end{array}$ \\
\hline De Clercq 2002 & Not a RCT, "systematically allocated". \\
\hline Druilhe 1981 & Not a RCT. \\
\hline el Hawey 1990 & No comparison group. \\
\hline el Tayeb 1988 & $\begin{array}{l}\text { This study compares praziquantel } 2 \times 20 \mathrm{mg} / \mathrm{kg} \text { to oltipraz } 2 \times 15 \mathrm{mg} / \mathrm{kg} \text {, which is now obsolete. De- } \\
\text { tails of this trial can be seen in earlier versions of this review. }\end{array}$ \\
\hline el-Zayadi 1985 & No outcome of interest reported. \\
\hline Erikstrup 2008 & $\begin{array}{l}\text { This is a study of HIV and S. haematobium or S. mansoni co-infection, no outcomes of interest for } \\
\text { this review are reported. }\end{array}$ \\
\hline Fontanilles 1964 & Conference speech. \\
\hline Forsyth 1964 & Not a RCT. "At three of the schools, every sixth injected child received "curative" treatment..." \\
\hline Garba 2001 & Study of health education. \\
\hline Garba 2004 & This study evaluates mass treatment with praziquantel without comparison group. \\
\hline Hammad 1997 & $\begin{array}{l}\text { This cross-sectional study evaluates the diagnosis of urinary schistosomiasis by reagent strip and } \\
\text { parasitological methods. }\end{array}$ \\
\hline Jewsbury 1977 & No comparison group (sequence of treatment, then prophylaxis within one group). \\
\hline Jinabhai 2001 & $\begin{array}{l}\text { This study compares a combination of praziquantel and albendazole with placebo. This outcome is } \\
\text { not of interest for this review. }\end{array}$ \\
\hline
\end{tabular}




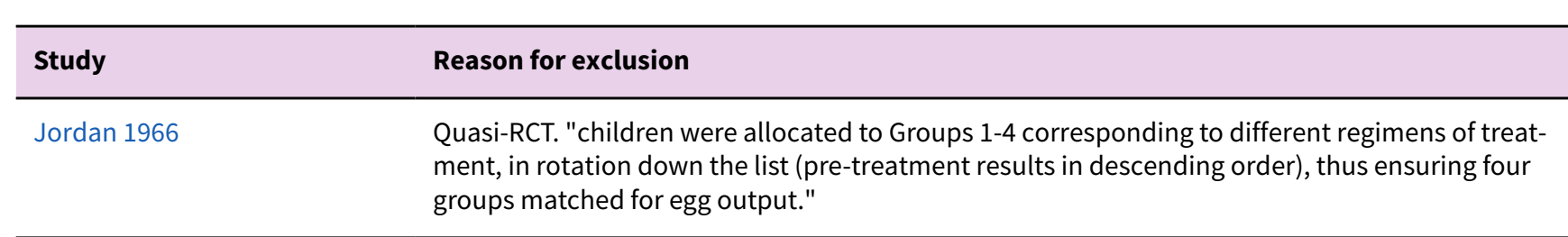

\begin{tabular}{|c|c|}
\hline Kardaman 1983 & No comparison group. \\
\hline Kern 1984 & $\begin{array}{l}\text { Study of intestinal manifestations of schistosomiasis, very low number for S. haematobium positive } \\
\text { patients, outcome data not reported separately. }\end{array}$ \\
\hline King 1989 & Review article. \\
\hline King 1992 & Data reported in other publications. \\
\hline Kurz 1986 & This study evaluates metrifonate in hookworm infections. \\
\hline Latham 1983 & No comparison group. \\
\hline Lucas 1969 & $\begin{array}{l}\text { This study reports ultrasound findings in patients with urinary schistosomiasis after treatment with } \\
\text { Niridazole to a untreated control. Niridazole is now obsolete. }\end{array}$ \\
\hline Mwanakasale 2009 & $\begin{array}{l}\text { Study of iron supplementation in S. haematobium treatment with no outcomes of interest for this } \\
\text { review. }\end{array}$ \\
\hline N'Goran 2003 & Study of S. haematobium prevention. \\
\hline Nagaty 1962 & This trial studies the therapy of drug side effects in urinary schistosomiasis treatment. \\
\hline Odongo-Aginya 1996 & Not a RCT, study of S. mansoni. \\
\hline Olsen 2007 & Review article. \\
\hline Pitchford 1978 & No comparison group. \\
\hline Podgore 1994 & Study of S. haematobium prevention. \\
\hline Rabarijaona 2001 & Epidemiological survey. \\
\hline Rey 1984 & $\begin{array}{l}\text { This study compares oltipraz } 30 \mathrm{mg} / \mathrm{kg} \text { to a combination of metrifonate } 10 \mathrm{mg} / \mathrm{kg} \text { and niridazole } 25 \\
\mathrm{mg} / \mathrm{kg} \text {. Niridazole and oltipraz are now obsolete. }\end{array}$ \\
\hline Rugemalila 1984 & Study of S. mansoni. \\
\hline Schutte 1983 & No comparison group. \\
\hline Sellin 1986 & This study compares metrifonate $10 \mathrm{mg} / \mathrm{kg}$ to oltipraz $30 \mathrm{mg} / \mathrm{kg}$, which is now obsolete. \\
\hline Sissoko $2009 \mathrm{MLI}$ & $\begin{array}{l}\text { This study compared praziquantel to a combination of artesunate with sulfamethoxypyrazine } \\
\text { pyrimethamine; it is therefore not possible to attribute observed effects to artesunate alone. }\end{array}$ \\
\hline Snyman 1997 & Study of calcitriol as experimental antischistosomal treatment. \\
\hline Snyman 1998 & Study of levimasole as experimental antischistosomal treatment. \\
\hline Squires 2000 & Review article. \\
\hline
\end{tabular}




\begin{tabular}{|c|c|}
\hline Study & Reason for exclusion \\
\hline Stephenson 1985 & $\begin{array}{l}\text { No comparison group (compares children of moderate and severe infection intensity with uninfect- } \\
\text { ed children, using the same treatment regimen for infected children). }\end{array}$ \\
\hline Taylor 2001 & $\begin{array}{l}\text { This study compares a combination of praziquantel and albendazole with placebo. This outcome is } \\
\text { not of interest for this review, whereas a comparison the combination of praziquantel and albenda- } \\
\text { zole versus praziquantel would be of interest. }\end{array}$ \\
\hline Teesdale 1980 & Not a RCT. \\
\hline Thigpen 2011 & Not a RCT. \\
\hline Urbani 1997 & Epidemiological survey. \\
\hline Utzinger 2001 & Review article. \\
\hline van Lieshout 1994 & Study of S. mansoni. \\
\hline Wilkins 1987 Simoto trial & Not a RCT, alternate allocation. \\
\hline Wolfe 1967 & Not a RCT. \\
\hline Xiao 2002 & Review article. \\
\hline Zwingenberger 1990 & Case study. \\
\hline
\end{tabular}

\section{DATA AND ANALYSES}

\section{Comparison 1. Praziquantel $40 \mathrm{mg} / \mathrm{kg}$ single dose versus placebo}

\begin{tabular}{lllll}
\hline Outcome or subgroup title & $\begin{array}{l}\text { No. of } \\
\text { studies }\end{array}$ & $\begin{array}{l}\text { No. of } \\
\text { partici- } \\
\text { pants }\end{array}$ & Statistical method & Effect size \\
\hline 1 Parasitological failure & 8 & & Risk Ratio $(\mathrm{M}-\mathrm{H}$, Random, 95\% Cl) & Subtotals only \\
\hline $\begin{array}{l}1.1 \text { at one month to two } \\
\text { months }\end{array}$ & 7 & 864 & Risk Ratio (M-H, Random, 95\% Cl) & $0.42[0.29,0.59]$ \\
\hline 1.2 at three months & 3 & 354 & Risk Ratio (M-H, Random, 95\% Cl) & $0.51[0.34,0.77]$ \\
\hline 1.3 at five months & 1 & 54 & Risk Ratio (M-H, Random, 95\% Cl) & $0.73[0.58,0.91]$ \\
\hline 1.4 at six months & 3 & 332 & Risk Ratio (M-H, Random, 95\% Cl) & $0.42[0.10,1.84]$ \\
\hline 1.5 at eight months & 1 & 209 & Risk Ratio (M-H, Random, 95\% Cl) & $0.14[0.08,0.22]$ \\
\hline 2 Haematuria at eight weeks & 1 & 119 & Risk Ratio (M-H, Fixed, 95\% Cl) & $0.53[0.33,0.84]$ \\
\hline 3 Haemoglobin & 2 & & Mean Difference (IV, Random, 95\% Cl) & Subtotals only
\end{tabular}




\begin{tabular}{|c|c|c|c|c|}
\hline Outcome or subgroup title & $\begin{array}{l}\text { No. of } \\
\text { studies }\end{array}$ & $\begin{array}{l}\text { No. of } \\
\text { partici- } \\
\text { pants }\end{array}$ & Statistical method & Effect size \\
\hline 3.2 at six to eight months & 2 & 727 & Mean Difference (IV, Random, 95\% CI) & $-0.08[-0.24,0.09]$ \\
\hline 4 Adverse events & 2 & & Risk Ratio (M-H, Fixed, 95\% Cl) & Subtotals only \\
\hline 4.1 Diarrhoea & 1 & 156 & Risk Ratio (M-H, Fixed, 95\% Cl) & $0.0[0.0,0.0]$ \\
\hline 4.2 Vomiting & 2 & 226 & Risk Ratio (M-H, Fixed, 95\% Cl) & $0.67[0.15,2.87]$ \\
\hline 4.3 Dizziness & 2 & 226 & Risk Ratio (M-H, Fixed, 95\% Cl) & $0.37[0.11,1.27]$ \\
\hline 4.4 Anorexia & 1 & 70 & Risk Ratio (M-H, Fixed, 95\% Cl) & $0.20[0.05,0.85]$ \\
\hline 4.5 Abdominal pain & 2 & 226 & Risk Ratio (M-H, Fixed, 95\% Cl) & $0.50[0.22,1.14]$ \\
\hline 4.6 Tiredness & 1 & 70 & Risk Ratio (M-H, Fixed, 95\% Cl) & $0.48[0.14,1.71]$ \\
\hline 4.7 Weakness & 1 & 70 & Risk Ratio (M-H, Fixed, 95\% Cl) & $0.96[0.36,2.57]$ \\
\hline 4.8 Headache & 2 & 226 & Risk Ratio (M-H, Fixed, 95\% Cl) & $0.19[0.02,1.47]$ \\
\hline 4.9 Fever & 2 & 226 & Risk Ratio (M-H, Fixed, 95\% Cl) & $1.12[0.07,17.22]$ \\
\hline 4.10 Pain in limbs & 1 & 70 & Risk Ratio (M-H, Fixed, 95\% Cl) & $5.59[0.28,112.34]$ \\
\hline 4.11 Itching & 1 & 156 & Risk Ratio (M-H, Fixed, 95\% Cl) & $1.0[0.19,5.28]$ \\
\hline 4.12 Cough & 1 & 156 & Risk Ratio (M-H, Fixed, 95\% Cl) & $1.0[0.09,10.78]$ \\
\hline 4.13 Chills & 1 & 156 & Risk Ratio (M-H, Fixed, 95\% Cl) & $1.5[0.16,14.07]$ \\
\hline 4.14 Nausea & 1 & 156 & Risk Ratio (M-H, Fixed, 95\% Cl) & $1.0[0.09,10.78]$ \\
\hline 4.15 Constipation & 1 & 156 & Risk Ratio (M-H, Fixed, 95\% Cl) & $1.51[0.06,36.54]$ \\
\hline
\end{tabular}

\section{Analysis 1.1. Comparison 1 Praziquantel $40 \mathrm{mg} / \mathrm{kg}$ single dose versus placebo, Outcome 1 Parasitological failure.}

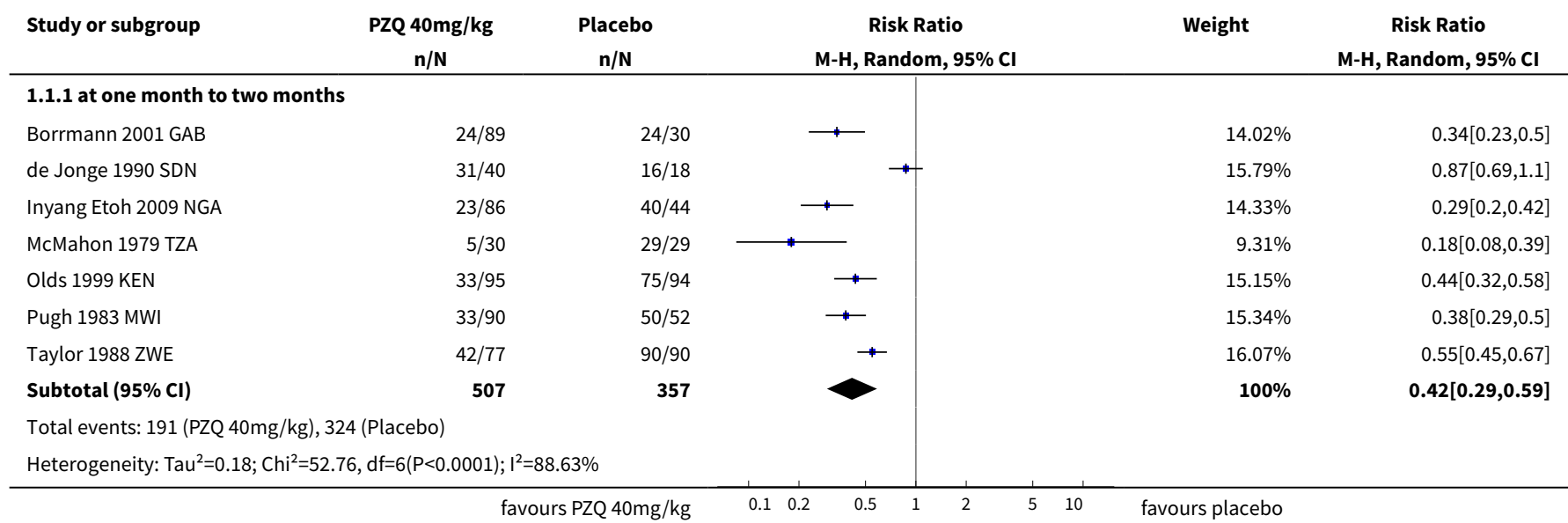




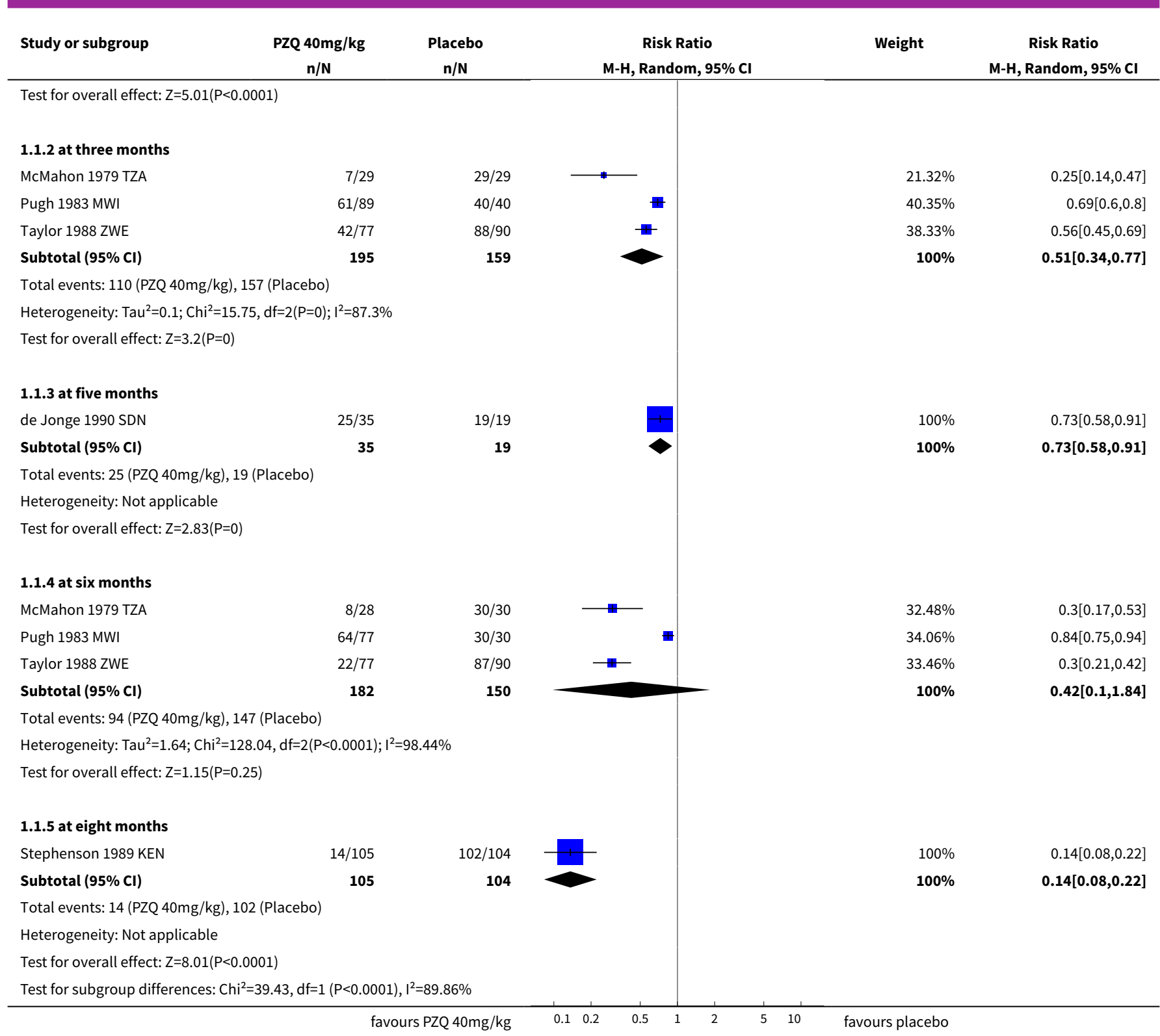

Analysis 1.2. Comparison 1 Praziquantel $40 \mathrm{mg} / \mathrm{kg}$ single dose versus placebo, Outcome $\mathbf{2}$ Haematuria at eight weeks.

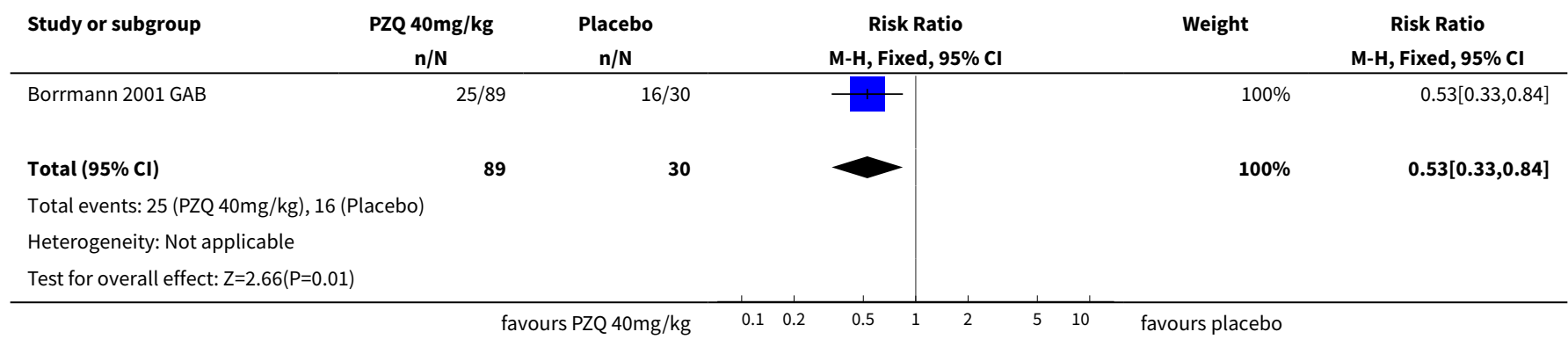


Analysis 1.3. Comparison 1 Praziquantel $40 \mathrm{mg} / \mathrm{kg}$ single dose versus placebo, Outcome 3 Haemoglobin.

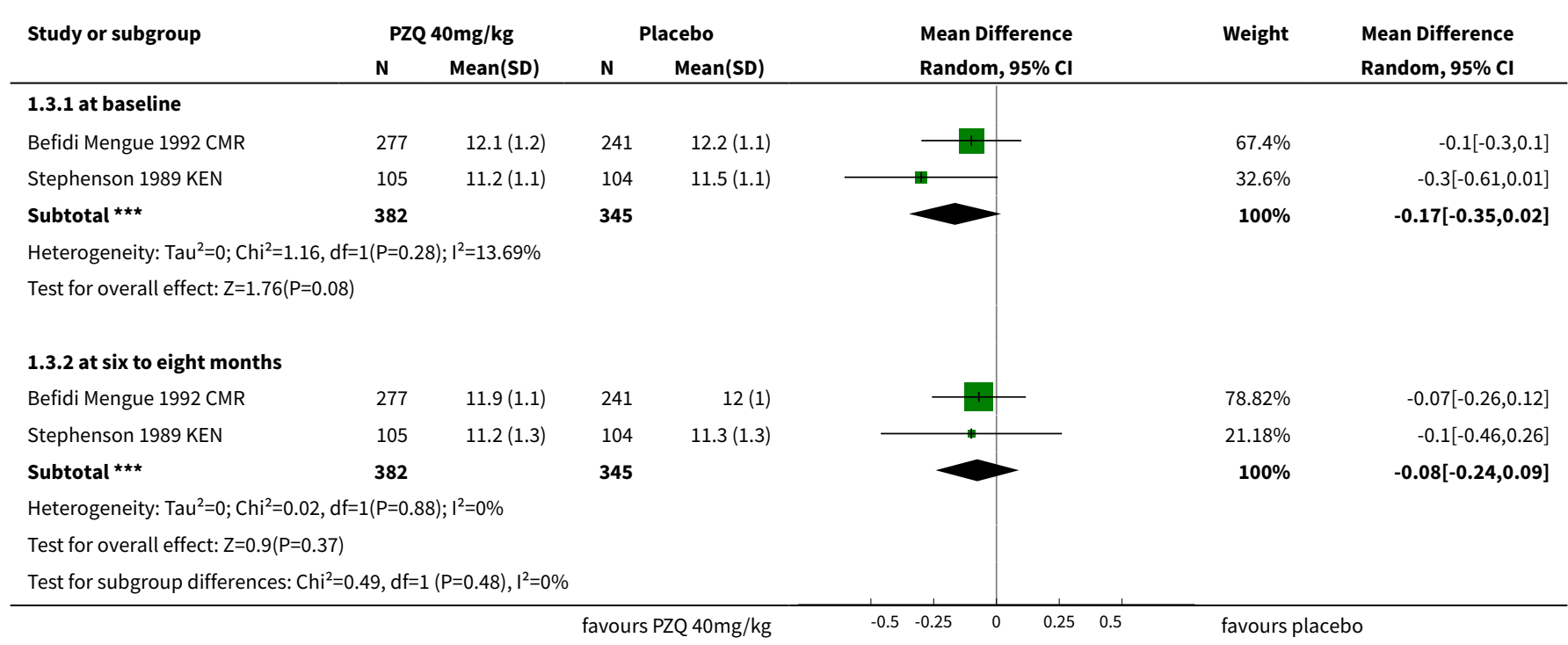

Analysis 1.4. Comparison 1 Praziquantel $40 \mathrm{mg} / \mathrm{kg}$ single dose versus placebo, Outcome 4 Adverse events.

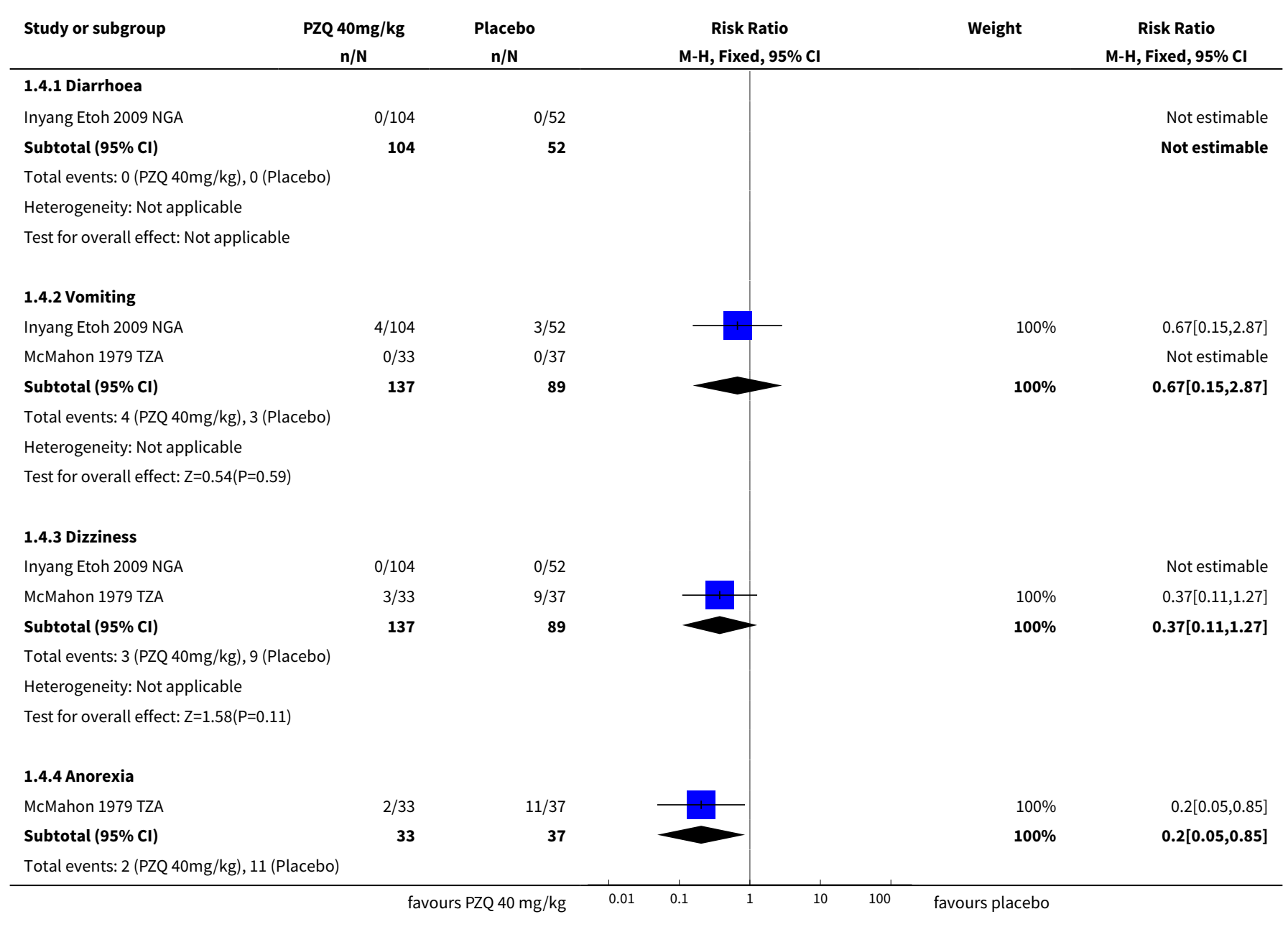

Drugs for treating urinary schistosomiasis (Review)

Copyright (c) 2014 The Authors. Cochrane Database of Systematic Reviews published by John Wiley \& Sons, Ltd. on behalf of The Cochrane Collaboration. 


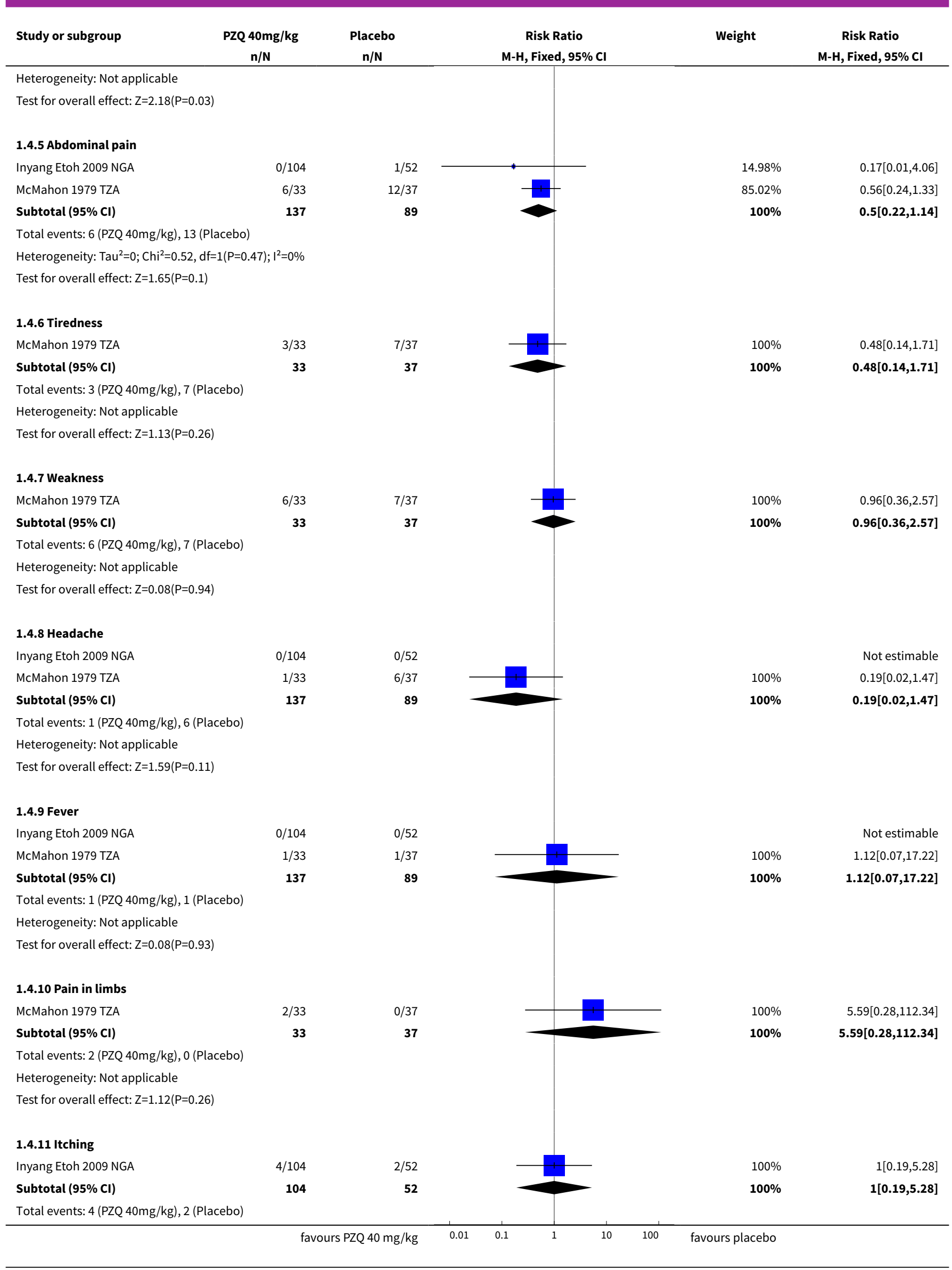

Drugs for treating urinary schistosomiasis (Review)

Copyright $\odot 2014$ The Authors. Cochrane Database of Systematic Reviews published by John Wiley \& Sons, Ltd. on behalf of The Cochrane Collaboration. 


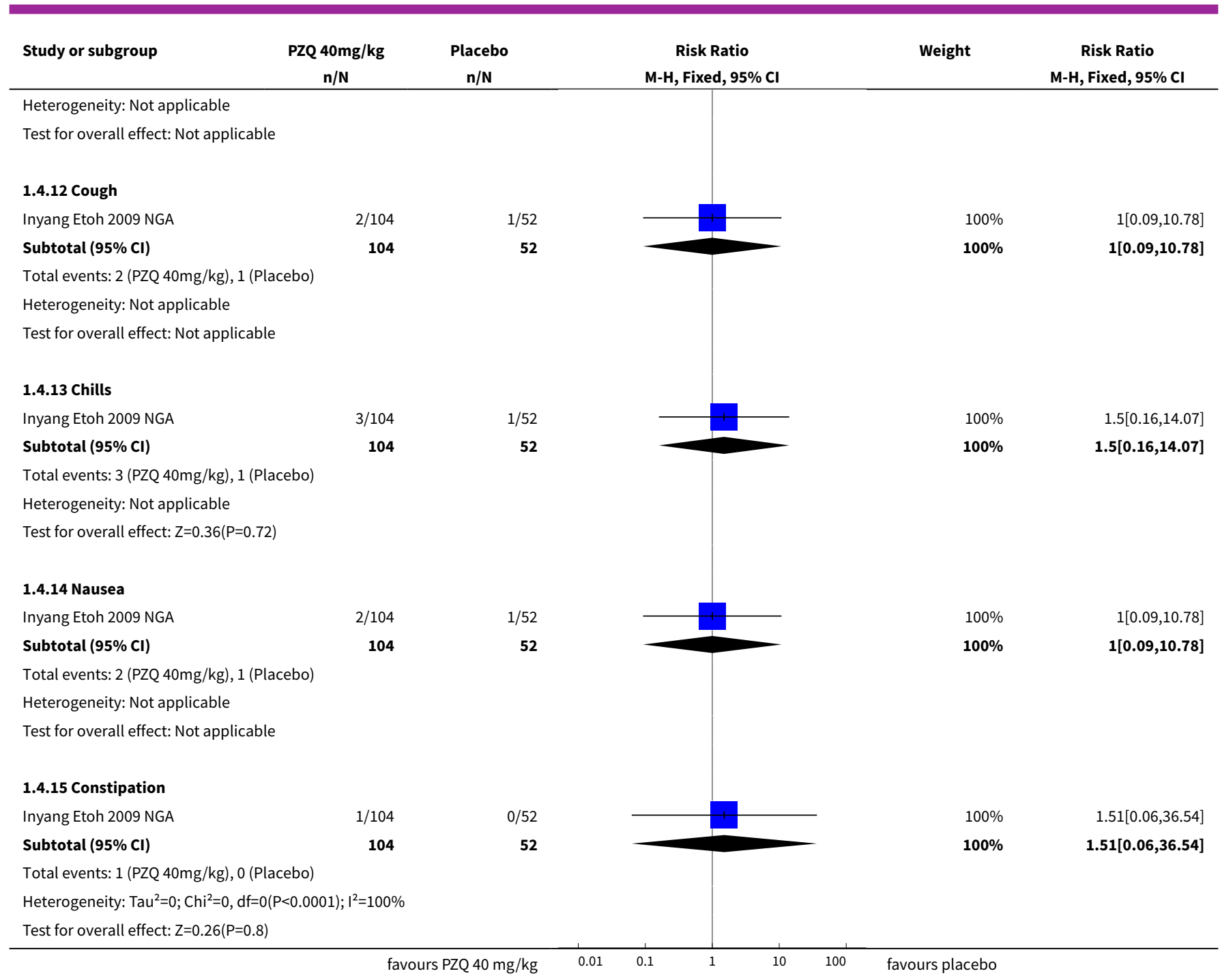

\section{Comparison 2. Praziquantel $40 \mathrm{mg} / \mathrm{kg}$ single dose versus lower doses}

\begin{tabular}{lllll}
\hline Outcome or subgroup title & $\begin{array}{l}\text { No. of } \\
\text { studies }\end{array}$ & $\begin{array}{l}\text { No. of } \\
\text { partici- } \\
\text { pants }\end{array}$ & Statistical method & Effect size \\
\hline $\begin{array}{l}1 \text { Parasitological failure at four to six } \\
\text { weeks }\end{array}$ & 5 & & Risk Ratio (M-H, Fixed, 95\% Cl) & Subtotals only \\
\hline 1.1 versus $30 \mathrm{mg} / \mathrm{kg}$ & 4 & 401 & Risk Ratio (M-H, Fixed, 95\% Cl) & $0.76[0.59,0.99]$ \\
\hline 1.2 versus $20 \mathrm{mg} / \mathrm{kg}$ & 2 & 338 & Risk Ratio (M-H, Fixed, 95\% Cl) & $0.74[0.59,0.93]$ \\
\hline 1.3 versus $10 \mathrm{mg} / \mathrm{kg}$ & 1 & 150 & Risk Ratio (M-H, Fixed, 95\% Cl) & $0.66[0.53,0.84]$ \\
\hline $\begin{array}{l}2 \text { Parasitological failure at two to } \\
\text { three months }\end{array}$ & 6 & & Risk Ratio (M-H, Fixed, 95\% Cl) & Subtotals only \\
\hline 2.1 versus $30 \mathrm{mg} / \mathrm{kg}$ & 5 & 517 & Risk Ratio (M-H, Fixed, 95\% Cl) & $0.95[0.72,1.24]$ \\
\hline
\end{tabular}

Drugs for treating urinary schistosomiasis (Review) 


\begin{tabular}{|c|c|c|c|c|}
\hline Outcome or subgroup title & $\begin{array}{l}\text { No. of } \\
\text { studies }\end{array}$ & $\begin{array}{l}\text { No. of } \\
\text { partici- } \\
\text { pants }\end{array}$ & Statistical method & Effect size \\
\hline 2.2 versus $20 \mathrm{mg} / \mathrm{kg}$ & 3 & 330 & Risk Ratio (M-H, Fixed, 95\% Cl) & $0.72[0.56,0.92]$ \\
\hline 2.3 versus $10 \mathrm{mg} / \mathrm{kg}$ & 3 & 339 & Risk Ratio (M-H, Fixed, 95\% Cl) & $0.48[0.39,0.60]$ \\
\hline $\begin{array}{l}3 \text { Parasitological failure at six to sev- } \\
\text { en months }\end{array}$ & 6 & & Risk Ratio (M-H, Fixed, 95\% Cl) & Subtotals only \\
\hline 3.1 versus $30 \mathrm{mg} / \mathrm{kg}$ & 6 & 669 & Risk Ratio (M-H, Fixed, 95\% Cl) & $0.97[0.76,1.23]$ \\
\hline 3.2 versus $20 \mathrm{mg} / \mathrm{kg}$ & 1 & 138 & Risk Ratio (M-H, Fixed, 95\% Cl) & $0.87[0.53,1.44]$ \\
\hline 3.3 versus $10 \mathrm{mg} / \mathrm{kg}$ & 1 & 150 & Risk Ratio (M-H, Fixed, 95\% Cl) & $0.43[0.29,0.64]$ \\
\hline 4 Haematuria at three months & 1 & & Risk Ratio (M-H, Fixed, 95\% Cl) & Subtotals only \\
\hline 4.1 versus $30 \mathrm{mg} / \mathrm{kg}$ & 1 & 117 & Risk Ratio (M-H, Fixed, 95\% Cl) & $0.89[0.47,1.67]$ \\
\hline 4.2 versus $20 \mathrm{mg} / \mathrm{kg}$ & 1 & 122 & Risk Ratio (M-H, Fixed, 95\% Cl) & $1.18[0.60,2.33]$ \\
\hline 4.3 versus $10 \mathrm{mg} / \mathrm{kg}$ & 1 & 119 & Risk Ratio (M-H, Fixed, 95\% Cl) & $0.35[0.21,0.58]$ \\
\hline 5 Proteinuria at three months & 1 & & Risk Ratio (M-H, Fixed, 95\% Cl) & Subtotals only \\
\hline 5.1 versus $30 \mathrm{mg} / \mathrm{kg}$ & 1 & 117 & Risk Ratio (M-H, Fixed, 95\% Cl) & $0.85[0.34,2.12]$ \\
\hline 5.2 versus $20 \mathrm{mg} / \mathrm{kg}$ & 1 & 122 & Risk Ratio (M-H, Fixed, 95\% Cl) & $0.92[0.36,2.30]$ \\
\hline 5.3 versus $10 \mathrm{mg} / \mathrm{kg}$ & 1 & 119 & Risk Ratio (M-H, Fixed, 95\% Cl) & $0.25[0.12,0.51]$ \\
\hline 6 Haematuria at six weeks & 1 & & Risk Ratio (M-H, Fixed, 95\% Cl) & Subtotals only \\
\hline 6.1 versus $20 \mathrm{mg} / \mathrm{kg}$ & 1 & 245 & Risk Ratio (M-H, Fixed, 95\% Cl) & $0.63[0.47,0.86]$ \\
\hline 7 Proteinuria at six weeks & 1 & & Risk Ratio (M-H, Fixed, 95\% Cl) & Subtotals only \\
\hline 7.1 versus $20 \mathrm{mg} / \mathrm{kg}$ & 1 & 245 & Risk Ratio (M-H, Fixed, 95\% Cl) & $0.66[0.46,0.96]$ \\
\hline 8 Haematuria at nine months & 1 & & Risk Ratio (M-H, Fixed, 95\% Cl) & Subtotals only \\
\hline 8.1 versus $20 \mathrm{mg} / \mathrm{kg}$ & 1 & 215 & Risk Ratio (M-H, Fixed, 95\% Cl) & $0.59[0.44,0.78]$ \\
\hline 9 Proteinuria at nine months & 1 & & Risk Ratio (M-H, Fixed, 95\% Cl) & Subtotals only \\
\hline 9.1 versus $20 \mathrm{mg} / \mathrm{kg}$ & 1 & 214 & Risk Ratio (M-H, Fixed, 95\% Cl) & $0.67[0.50,0.90]$ \\
\hline 10 Adverse events & 2 & & Risk Ratio (M-H, Random, 95\% Cl) & Subtotals only \\
\hline 10.1 Vomiting & 2 & 163 & Risk Ratio (M-H, Random, 95\% Cl) & $0.79[0.05,13.51]$ \\
\hline 10.2 Dizziness & 2 & 163 & Risk Ratio (M-H, Random, 95\% Cl) & $0.73[0.11,4.62]$ \\
\hline 10.3 Anorexia & 1 & 65 & Risk Ratio (M-H, Random, 95\% Cl) & $4.85[0.24,97.31]$ \\
\hline
\end{tabular}




\begin{tabular}{llllll}
\hline Outcome or subgroup title & $\begin{array}{l}\text { No. of } \\
\text { studies }\end{array}$ & $\begin{array}{l}\text { No. of } \\
\text { partici- } \\
\text { pants }\end{array}$ & Statistical method & Effect size \\
\hline 10.4 Abdominal pain & 2 & 163 & Risk Ratio $(\mathrm{M}-\mathrm{H}$, Random, 95\% Cl) & $1.14[0.23,5.56]$ \\
\hline 10.5 Tiredness & 1 & 65 & Risk Ratio (M-H, Random, 95\% Cl) & $0.32[0.10,1.09]$ \\
\hline 10.6 Weakness & 1 & 65 & Risk Ratio (M-H, Random, 95\% Cl) & $1.16[0.39,3.44]$ \\
\hline 10.7 Headache & 2 & 163 & Risk Ratio (M-H, Random, 95\% Cl) & $0.49[0.08,2.85]$ \\
\hline 10.8 Fever & 1 & 65 & Risk Ratio (M-H, Random, 95\% Cl) & $2.91[0.12,68.95]$ \\
\hline 10.9 Pain in limbs & 1 & 65 & Risk Ratio (M-H, Random, 95\% Cl) & $0.39[0.08,1.86]$ \\
\hline
\end{tabular}

\section{Analysis 2.1. Comparison 2 Praziquantel $40 \mathrm{mg} / \mathrm{kg}$ single dose versus lower doses, Outcome 1 Parasitological failure at four to six weeks.}

\begin{tabular}{|c|c|c|c|c|c|}
\hline Study or subgroup & $\begin{array}{c}\text { PZQ 40mg/kg } \\
n / N\end{array}$ & $\begin{array}{l}\text { Lower doses } \\
n / N\end{array}$ & $\begin{array}{c}\text { Risk Ratio } \\
\text { M-H, Fixed, 95\% Cl }\end{array}$ & Weight & $\begin{array}{c}\text { Risk Ratio } \\
\text { M-H, Fixed, 95\% Cl }\end{array}$ \\
\hline \multicolumn{6}{|c|}{2.1 .1 versus $30 \mathrm{mg} / \mathrm{kg}$} \\
\hline McMahon 1979 TZA & $5 / 30$ & $9 / 31$ & $\longrightarrow$ & $13.86 \%$ & $0.57[0.22,1.52]$ \\
\hline Rey 1983 NER & $3 / 54$ & $1 / 39$ & 1 & $1.82 \%$ & $2.17[0.23,20.06]$ \\
\hline Davis 1981 ZMB & $0 / 45$ & $3 / 53$ & & $5.04 \%$ & $0.17[0.01,3.16]$ \\
\hline Taylor 1988 ZWE & $42 / 77$ & $49 / 72$ & & $79.28 \%$ & $0.8[0.62,1.04]$ \\
\hline \multicolumn{6}{|c|}{ Total events: 50 (PZQ 40mg/kg), 62 (Lower doses) } \\
\hline \multicolumn{6}{|c|}{ Heterogeneity: $\mathrm{Tau}^{2}=0 ; \mathrm{Chi}^{2}=2.34, \mathrm{df}=3(\mathrm{P}=0.51) ; \mathrm{I}^{2}=0 \%$} \\
\hline \multicolumn{6}{|c|}{ Test for overall effect: $Z=2.05(P=0.04)$} \\
\hline \multicolumn{6}{|l|}{2.1 .2 versus $20 \mathrm{mg} / \mathrm{kg}$} \\
\hline Taylor 1988 ZWE & $42 / 77$ & $37 / 61$ & & $45.48 \%$ & $0.9[0.67,1.2]$ \\
\hline Subtotal $(95 \% \mathrm{Cl})$ & 178 & 160 & $\boldsymbol{\nabla}$ & $100 \%$ & $0.74[0.59,0.93]$ \\
\hline \multicolumn{6}{|c|}{ Total events: 72 (PZQ 40mg/kg), 86 (Lower doses) } \\
\hline \multicolumn{6}{|c|}{ Heterogeneity: $\operatorname{Tau}^{2}=0 ; \mathrm{Chi}^{2}=3.1, \mathrm{df}=1(\mathrm{P}=0.08) ; \mathrm{I}^{2}=67.78 \%$} \\
\hline \multicolumn{6}{|c|}{ Test for overall effect: $Z=2.63(P=0.01)$} \\
\hline \multicolumn{6}{|c|}{2.1 .3 versus $10 \mathrm{mg} / \mathrm{kg}$} \\
\hline Taylor 1988 ZWE & $42 / 77$ & $60 / 73$ & & $100 \%$ & $0.66[0.53,0.84]$ \\
\hline Subtotal $(95 \% \mathrm{Cl})$ & 77 & 73 & $\nabla$ & $100 \%$ & $0.66[0.53,0.84]$ \\
\hline \multicolumn{6}{|c|}{ Total events: 42 (PZQ 40mg/kg), 60 (Lower doses) } \\
\hline \multicolumn{6}{|c|}{ Heterogeneity: Not applicable } \\
\hline \multicolumn{6}{|c|}{ Test for overall effect: $Z=3.49(P=0)$} \\
\hline Test for subgroup dif & $.7, \mathrm{df}=1(\mathrm{P}=0.7), \mathrm{I}^{2}=$ & & & & \\
\hline
\end{tabular}


Analysis 2.2. Comparison 2 Praziquantel $40 \mathrm{mg} / \mathrm{kg}$ single dose versus lower doses, Outcome 2 Parasitological failure at two to three months.

\begin{tabular}{|c|c|c|c|c|c|}
\hline Study or subgroup & $\begin{array}{c}\mathrm{PZQ} 40 \mathrm{mg} / \mathrm{kg} \\
\mathrm{n} / \mathrm{N}\end{array}$ & $\begin{array}{c}\text { Lower doses } \\
n / N\end{array}$ & $\begin{array}{c}\text { Risk Ratio } \\
\text { M-H, Fixed, } 95 \% \mathrm{Cl}\end{array}$ & Weight & $\begin{array}{c}\text { Risk Ratio } \\
\text { M-H, Fixed, } 95 \% \mathrm{Cl}\end{array}$ \\
\hline \multicolumn{6}{|c|}{2.2 .1 versus $30 \mathrm{mg} / \mathrm{kg}$} \\
\hline Rey 1983 NER & $4 / 52$ & $2 / 42$ & + & $3.39 \%$ & $1.62[0.31,8.39]$ \\
\hline McMahon 1979 TZA & $7 / 29$ & $9 / 31$ & - & $13.33 \%$ & $0.83[0.36,1.94]$ \\
\hline Davis 1981 ZMB & $1 / 45$ & $5 / 53$ & \begin{tabular}{l|l}
. & -
\end{tabular} & $7.04 \%$ & $0.24[0.03,1.94]$ \\
\hline Taylor 1988 ZWE & $42 / 77$ & $36 / 72$ & & $57.01 \%$ & $1.09[0.8,1.48]$ \\
\hline King 1989 KEN & $9 / 56$ & $13 / 60$ & $\rightarrow$ & $19.23 \%$ & $0.74[0.34,1.6]$ \\
\hline Subtotal $(95 \% \mathrm{Cl})$ & 259 & 258 & $\diamond$ & $100 \%$ & $0.95[0.72,1.24]$ \\
\hline \multicolumn{6}{|c|}{ Total events: 63 (PZQ 40mg/kg), 65 (Lower doses) } \\
\hline \multicolumn{6}{|c|}{ Heterogeneity: $\mathrm{Tau}^{2}=0 ; \mathrm{Chi}^{2}=3.36, \mathrm{df}=4(\mathrm{P}=0.5) ; 1^{2}=0 \%$} \\
\hline \multicolumn{6}{|c|}{ Test for overall effect: $Z=0.39(P=0.69)$} \\
\hline \multicolumn{6}{|c|}{2.2 .2 versus $20 \mathrm{mg} / \mathrm{kg}$} \\
\hline Wilkins 1987 GMB & $11 / 33$ & $18 / 35$ & $\rightarrow$ & $21.61 \%$ & $0.65[0.36,1.16]$ \\
\hline Taylor 1988 ZWE & $42 / 77$ & $39 / 61$ & H & $53.82 \%$ & $0.85[0.65,1.13]$ \\
\hline King 1989 KEN & $9 / 56$ & $22 / 68$ & $\rightarrow-$ & $24.57 \%$ & $0.5[0.25,0.99]$ \\
\hline Subtotal $(95 \% \mathrm{Cl})$ & 166 & 164 & $\diamond$ & $100 \%$ & $0.72[0.56,0.92]$ \\
\hline \multicolumn{6}{|c|}{ Total events: 62 (PZQ 40mg/kg), 79 (Lower doses) } \\
\hline \multicolumn{6}{|c|}{ Heterogeneity: $\mathrm{Tau}^{2}=0 ; \mathrm{Chi}^{2}=2.66, \mathrm{df}=2(\mathrm{P}=0.26) ; 1^{2}=24.72 \%$} \\
\hline \multicolumn{6}{|c|}{ Test for overall effect: $Z=2.61(P=0.01)$} \\
\hline \multicolumn{6}{|c|}{ 2.2.3 versus $10 \mathrm{mg} / \mathrm{kg}$} \\
\hline Wilkins 1987 GMB & $11 / 33$ & $28 / 38$ & $\rightarrow$ & $20.3 \%$ & $0.45[0.27,0.76]$ \\
\hline Taylor 1988 ZWE & $42 / 77$ & $57 / 73$ & $\mathbf{+}$ & $45.64 \%$ & $0.7[0.55,0.89]$ \\
\hline King 1989 KEN & $9 / 56$ & $46 / 62$ & $\rightarrow-$ & $34.05 \%$ & $0.22[0.12,0.4]$ \\
\hline Subtotal $(95 \% \mathrm{Cl})$ & 166 & 173 & $\diamond$ & $100 \%$ & $0.48[0.39,0.6]$ \\
\hline \multicolumn{6}{|c|}{ Total events: 62 (PZQ 40mg/kg), 131 (Lower doses) } \\
\hline \multicolumn{6}{|c|}{ Heterogeneity: $\mathrm{Tau}^{2}=0 ; \mathrm{Chi}^{2}=15.75, \mathrm{df}=2(\mathrm{P}=0) ; \mathrm{I}^{2}=87.3 \%$} \\
\hline \multicolumn{6}{|c|}{ Test for overall effect: $Z=6.55(P<0.0001)$} \\
\hline \multicolumn{6}{|c|}{ Test for subgroup differences: $\mathrm{Chi}^{2}=15.01, \mathrm{df}=1(\mathrm{P}=0), \mathrm{I}^{2}=86.68 \%$} \\
\hline
\end{tabular}

$\begin{array}{lllllll}\text { PZQ 40mg } / \mathrm{kg} & 0.005 & 0.1 & 1 & 10 & 200 & \text { Lower doses }\end{array}$

Analysis 2.3. Comparison 2 Praziquantel $40 \mathrm{mg} / \mathrm{kg}$ single dose versus lower doses, Outcome 3 Parasitological failure at six to seven months.

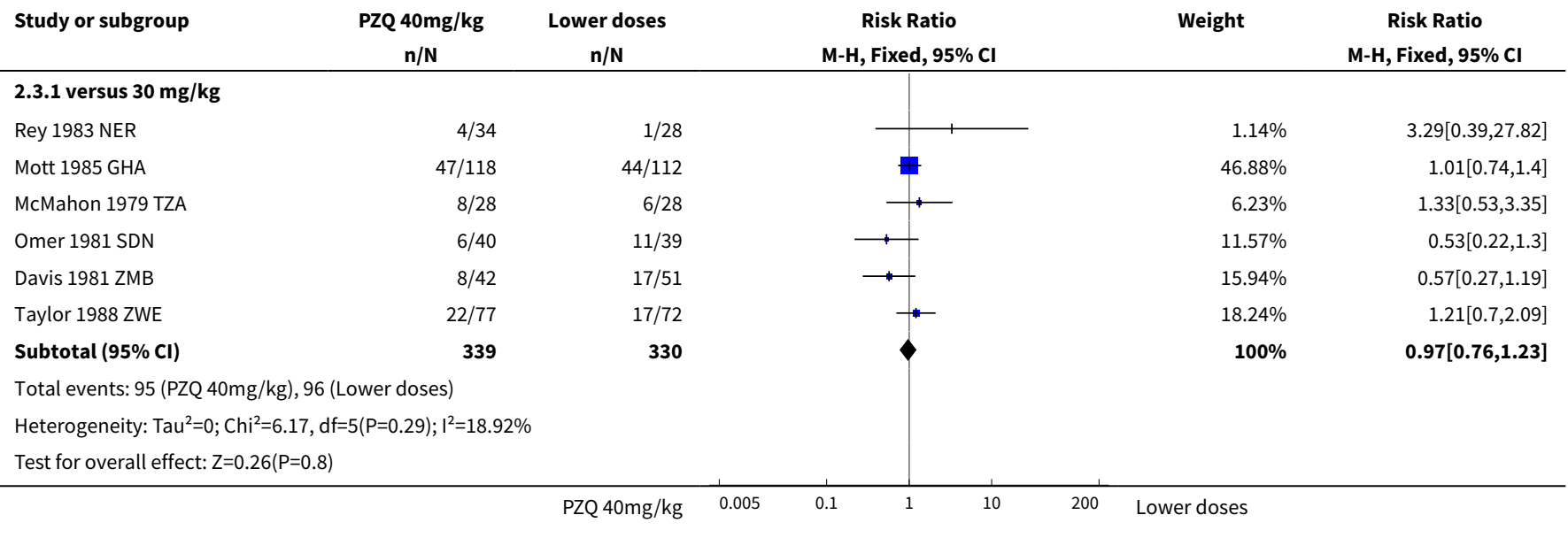

Drugs for treating urinary schistosomiasis (Review)

Copyright $\odot 2014$ The Authors. Cochrane Database of Systematic Reviews published by John Wiley \& Sons, Ltd. on behalf of The Cochrane Collaboration. 


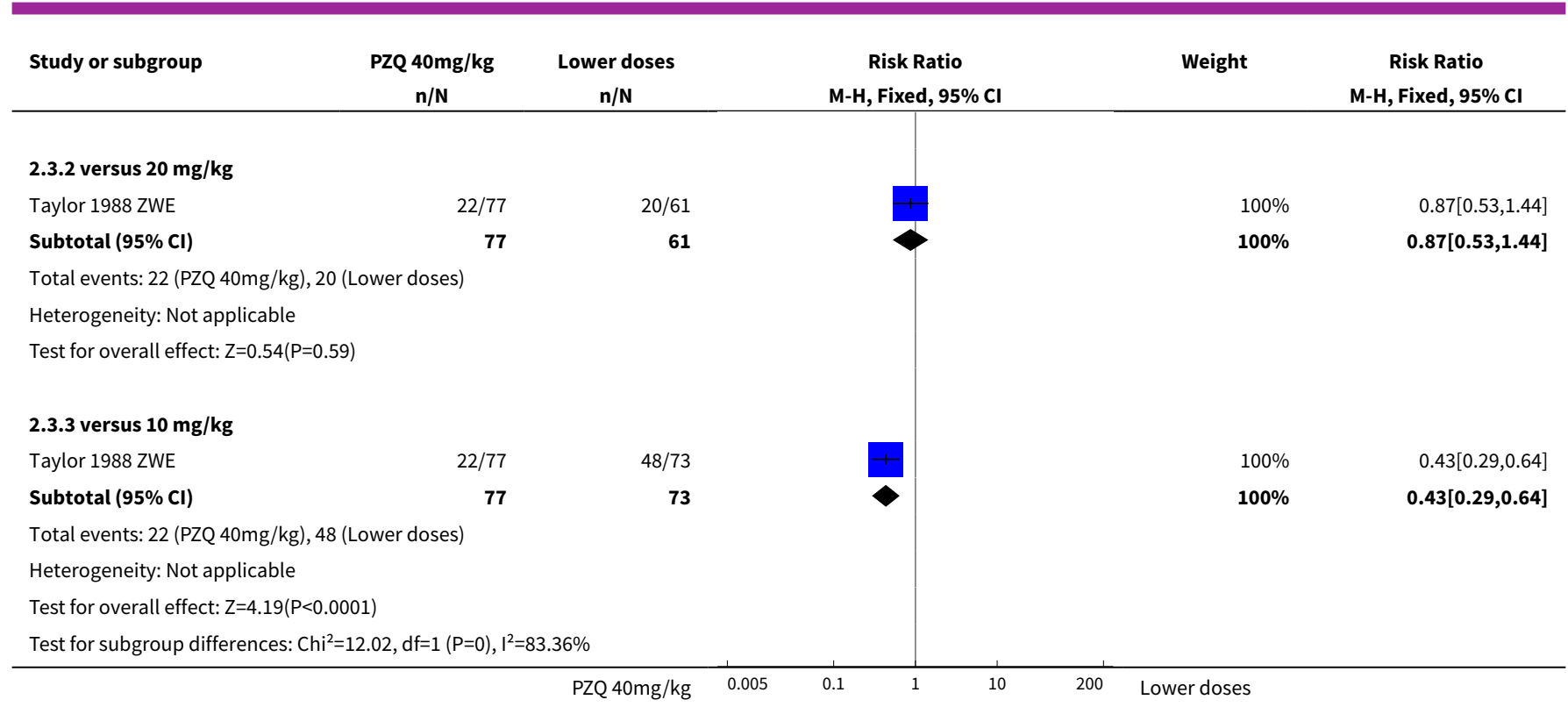

Analysis 2.4. Comparison 2 Praziquantel $40 \mathrm{mg} / \mathrm{kg}$ single dose versus lower doses, Outcome 4 Haematuria at three months.

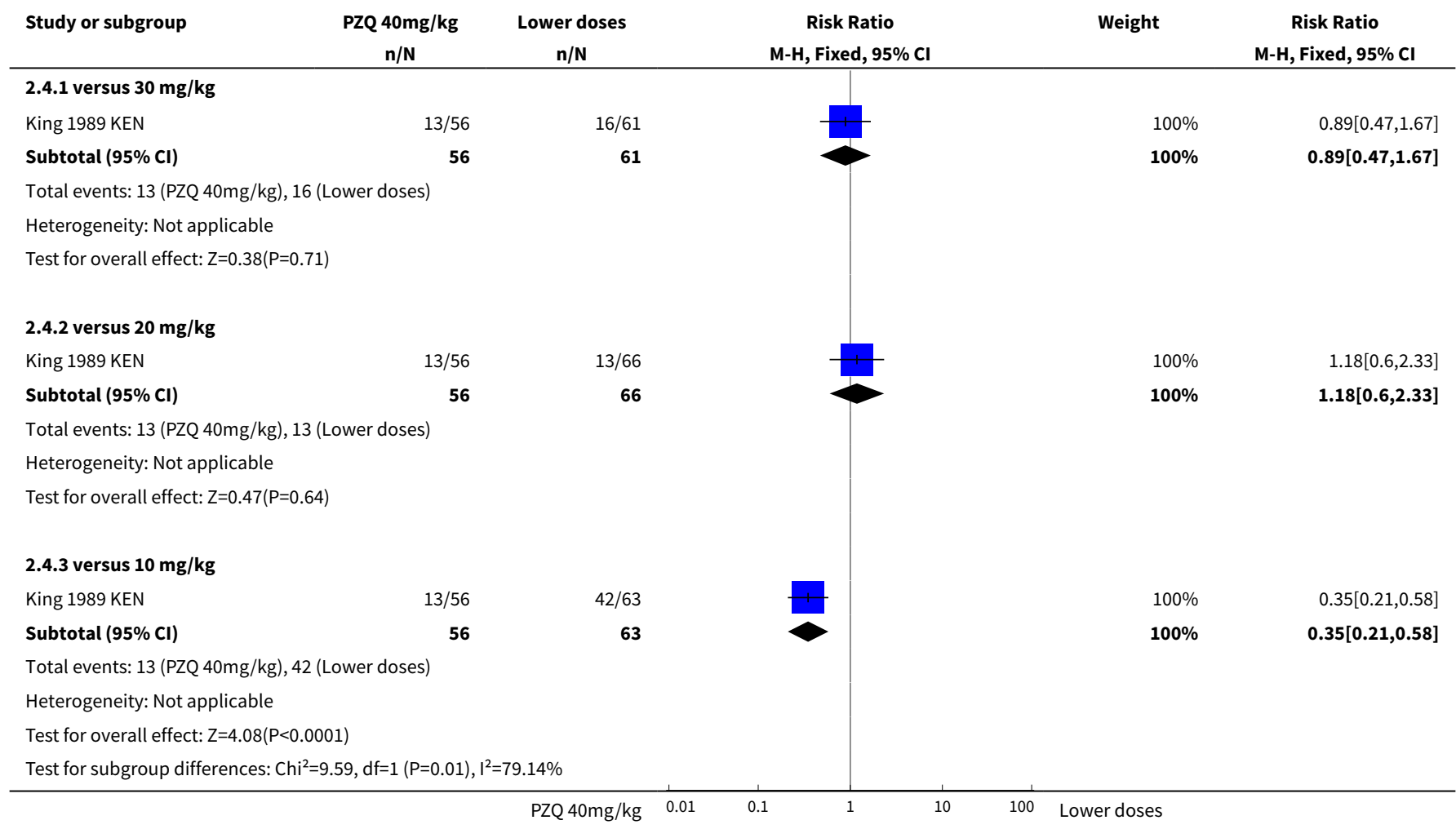

Drugs for treating urinary schistosomiasis (Review) 
Analysis 2.5. Comparison 2 Praziquantel $40 \mathrm{mg} / \mathrm{kg}$ single dose versus lower doses, Outcome 5 Proteinuria at three months.

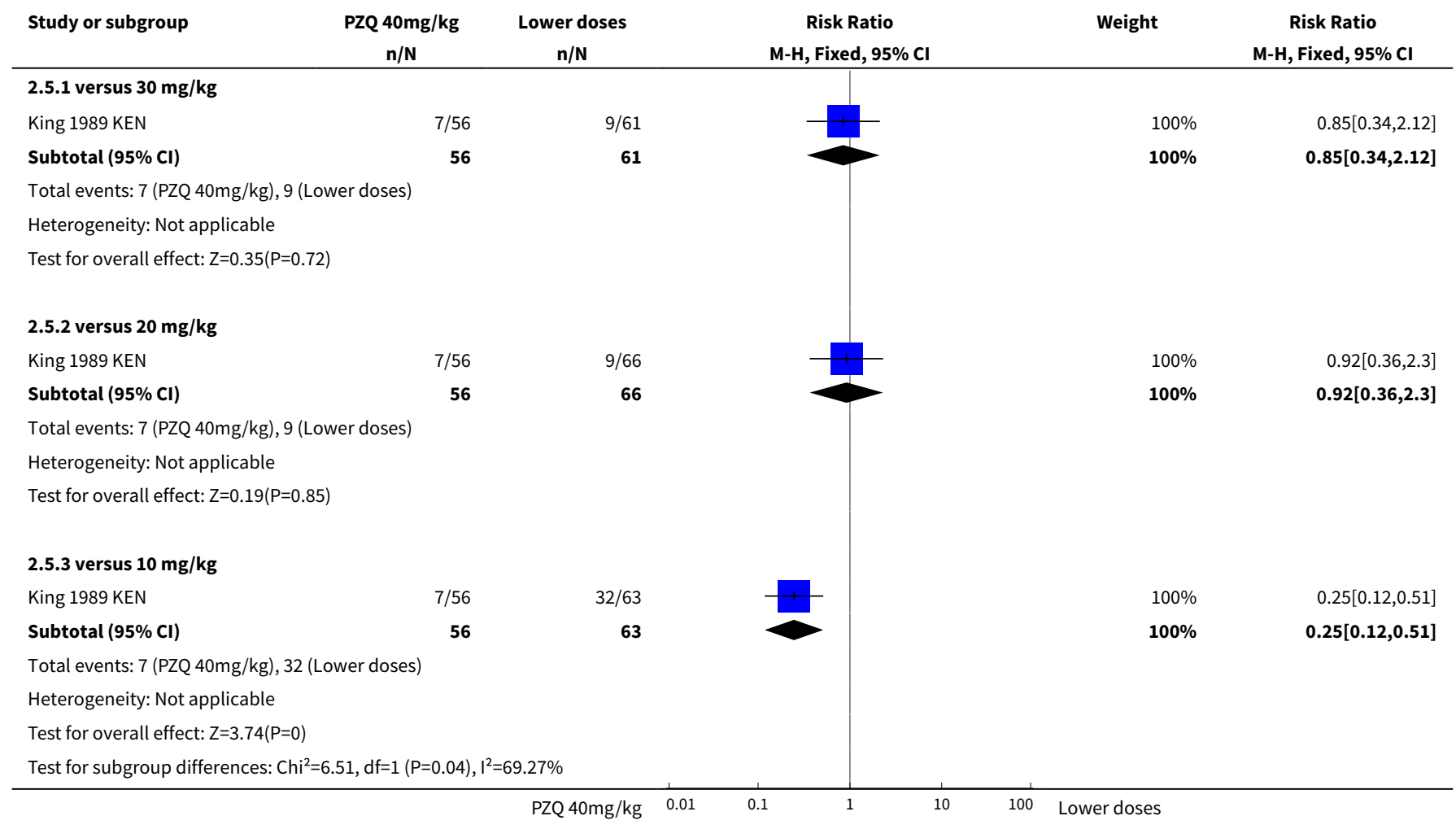

Analysis 2.6. Comparison 2 Praziquantel $40 \mathrm{mg} / \mathrm{kg}$ single dose versus lower doses, Outcome 6 Haematuria at six weeks.

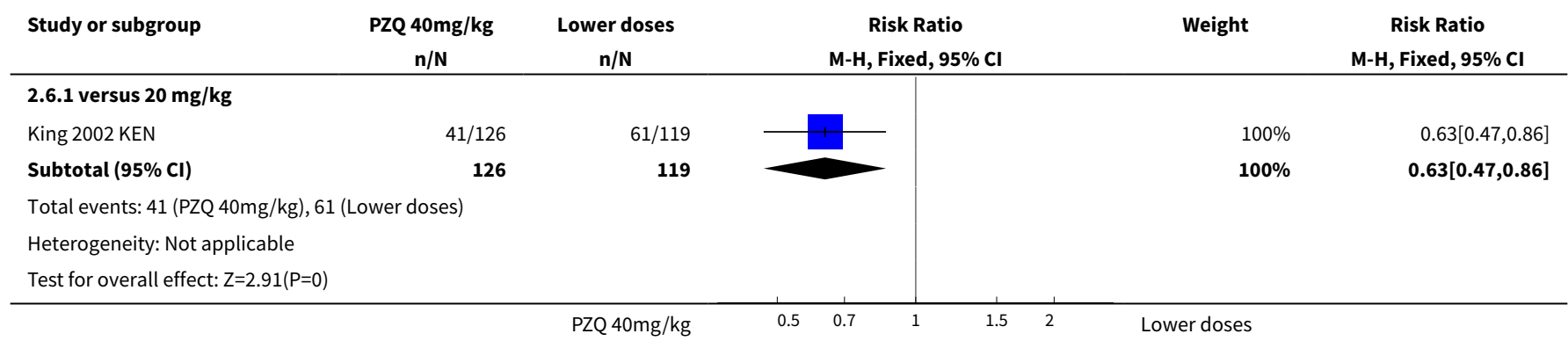

Analysis 2.7. Comparison 2 Praziquantel $40 \mathrm{mg} / \mathrm{kg}$ single dose versus lower doses, Outcome 7 Proteinuria at six weeks.

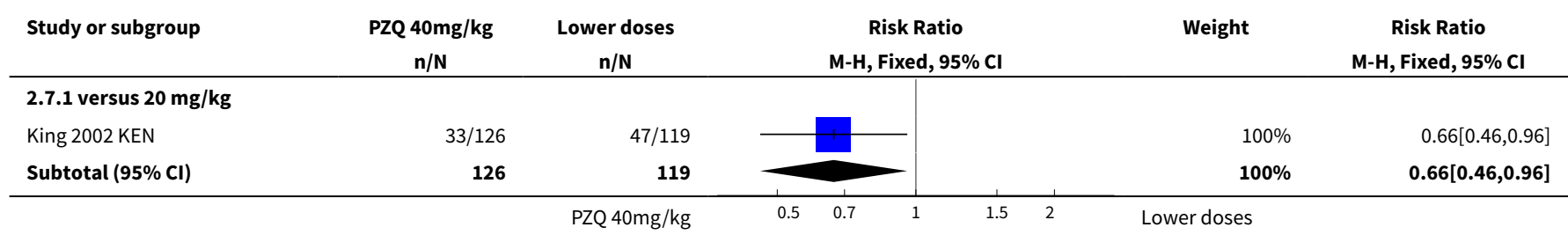




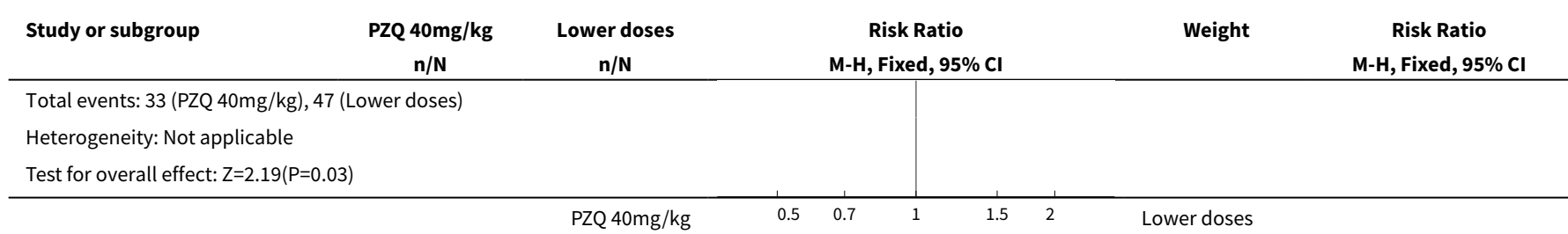

Analysis 2.8. Comparison 2 Praziquantel $40 \mathrm{mg} / \mathrm{kg}$ single dose versus lower doses, Outcome 8 Haematuria at nine months.

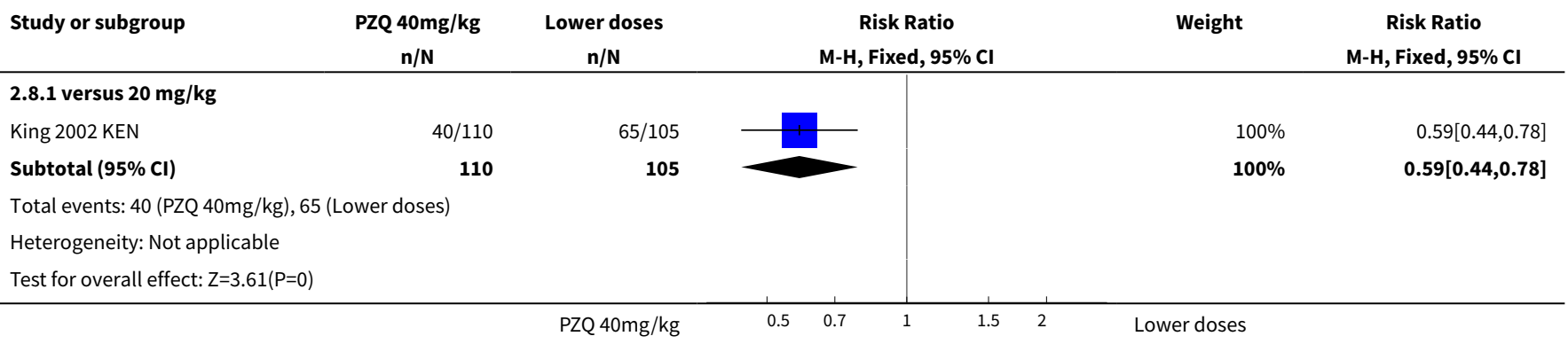

\section{Analysis 2.9. Comparison 2 Praziquantel $40 \mathrm{mg} / \mathrm{kg}$ single dose versus lower doses, Outcome 9 Proteinuria at nine months.}

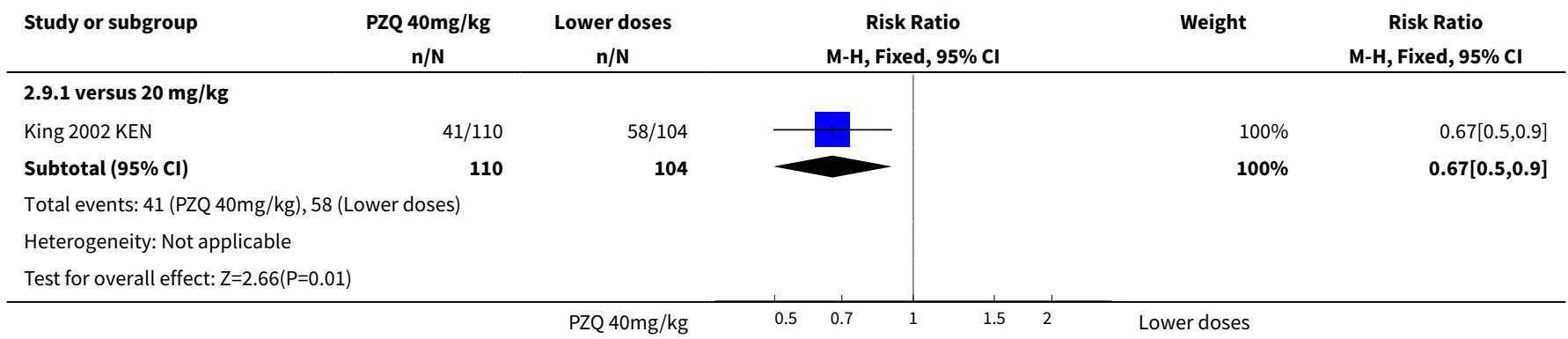

\section{Analysis 2.10. Comparison 2 Praziquantel $40 \mathrm{mg} / \mathrm{kg}$ single dose versus lower doses, Outcome 10 Adverse events.}

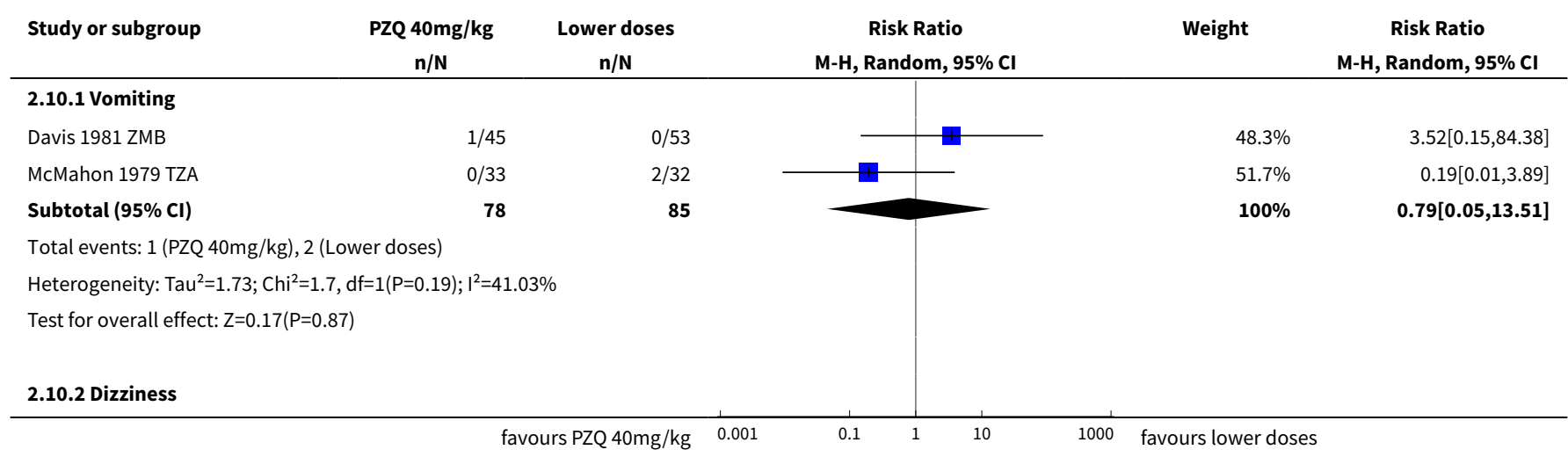




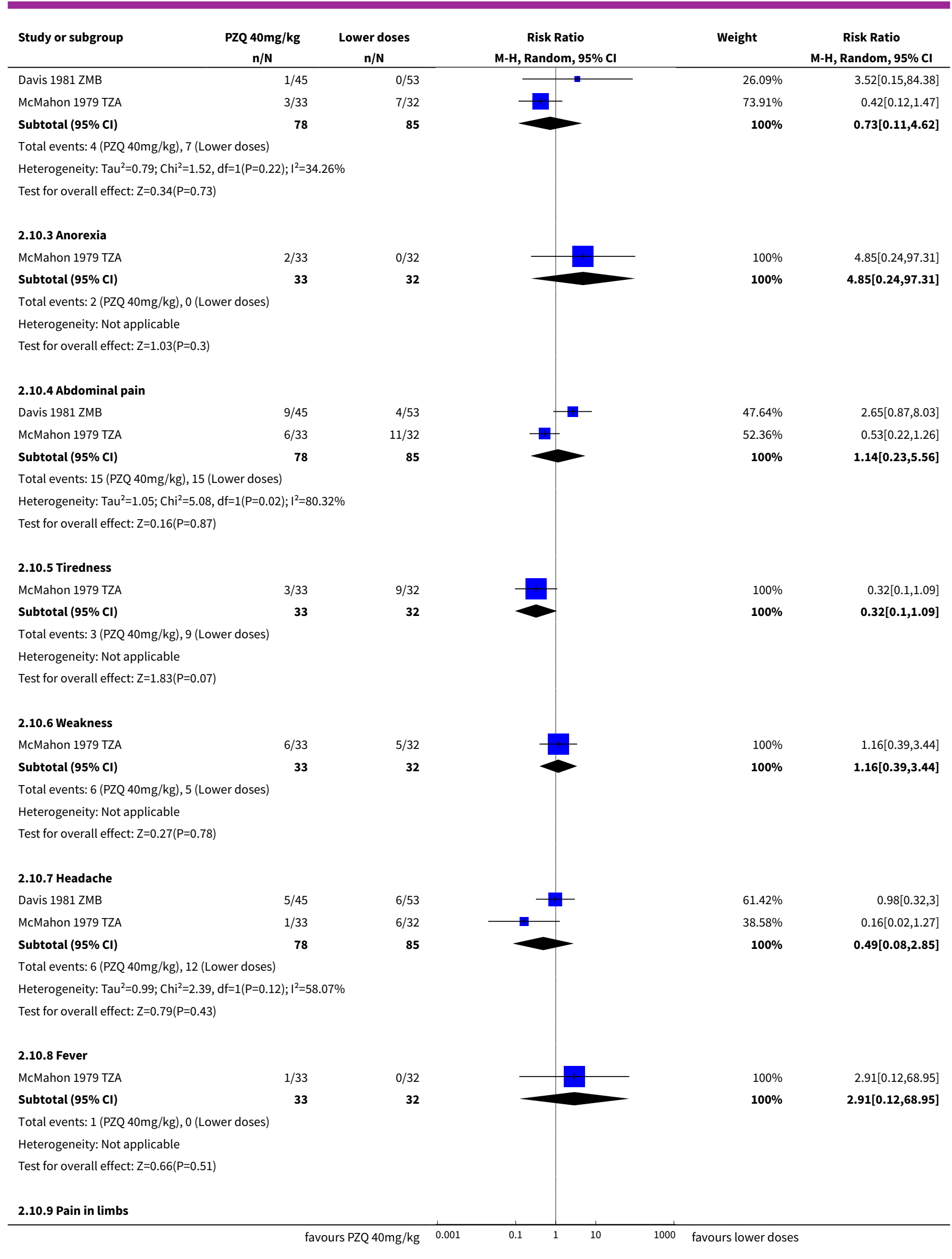

Drugs for treating urinary schistosomiasis (Review)

Copyright ( 2014 The Authors. Cochrane Database of Systematic Reviews published by John Wiley \& Sons, Ltd. on behalf of The Cochrane Collaboration. 


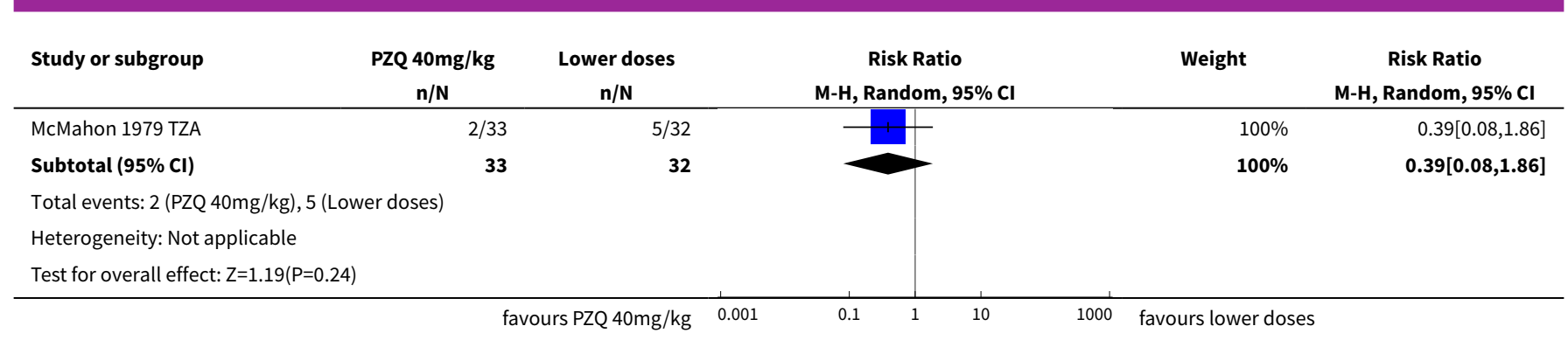

Comparison 3. Praziquantel $40 \mathrm{mg} / \mathrm{kg}$ single dose versus $2 \times 20 \mathrm{mg} / \mathrm{kg}$ split dose

\begin{tabular}{|c|c|c|c|c|}
\hline Outcome or subgroup title & $\begin{array}{l}\text { No. of } \\
\text { studies }\end{array}$ & $\begin{array}{l}\text { No. of } \\
\text { partici- } \\
\text { pants }\end{array}$ & Statistical method & Effect size \\
\hline 1 Parasitological failure & 4 & & Risk Ratio (M-H, Fixed, 95\% Cl) & Subtotals only \\
\hline 1.1 at one month & 3 & 374 & Risk Ratio (M-H, Fixed, 95\% Cl) & $0.75[0.51,1.11]$ \\
\hline 1.2 at three months & 3 & 361 & Risk Ratio (M-H, Fixed, 95\% Cl) & $0.74[0.45,1.20]$ \\
\hline 1.3 at six to seven months & 3 & 234 & Risk Ratio (M-H, Fixed, 95\% Cl) & $0.83[0.51,1.35]$ \\
\hline 2 Adverse events & 3 & & Risk Ratio (M-H, Fixed, 95\% Cl) & Subtotals only \\
\hline 2.1 Blood in stool & 1 & 215 & Risk Ratio (M-H, Fixed, 95\% Cl) & $0.0[0.0,0.0]$ \\
\hline 2.2 Vomiting & 3 & 373 & Risk Ratio (M-H, Fixed, 95\% Cl) & $0.50[0.29,0.86]$ \\
\hline 2.3 Dizziness & 3 & 373 & Risk Ratio (M-H, Fixed, 95\% Cl) & $0.39[0.16,0.94]$ \\
\hline 2.4 Anorexia & 1 & 69 & Risk Ratio (M-H, Fixed, 95\% Cl) & $2.18[0.21,22.96]$ \\
\hline 2.5 Abdominal pain & 3 & 373 & Risk Ratio (M-H, Fixed, 95\% Cl) & $1.02[0.83,1.25]$ \\
\hline 2.6 Tiredness & 1 & 69 & Risk Ratio (M-H, Fixed, 95\% Cl) & $0.41[0.12,1.41]$ \\
\hline 2.7 Weakness & 1 & 69 & Risk Ratio (M-H, Fixed, 95\% Cl) & $0.94[0.35,2.50]$ \\
\hline 2.8 Headache & 2 & 158 & Risk Ratio (M-H, Fixed, 95\% Cl) & $0.51[0.20,1.33]$ \\
\hline 2.9 Fever & 2 & 284 & Risk Ratio (M-H, Fixed, 95\% Cl) & $0.53[0.23,1.23]$ \\
\hline 2.10 Pain in limbs & 1 & 69 & Risk Ratio (M-H, Fixed, 95\% Cl) & $0.44[0.09,2.10]$ \\
\hline 2.11 Diarrhoea & 1 & 215 & Risk Ratio (M-H, Fixed, 95\% Cl) & $1.07[0.67,1.73]$ \\
\hline 2.12 Skin reaction & 1 & 215 & Risk Ratio (M-H, Fixed, 95\% Cl) & $1.84[0.34,9.83]$ \\
\hline
\end{tabular}


Analysis 3.1. Comparison 3 Praziquantel $40 \mathrm{mg} / \mathrm{kg}$ single dose versus $2 \times 20 \mathrm{mg} / \mathrm{kg}$ split dose, Outcome 1 Parasitological failure.

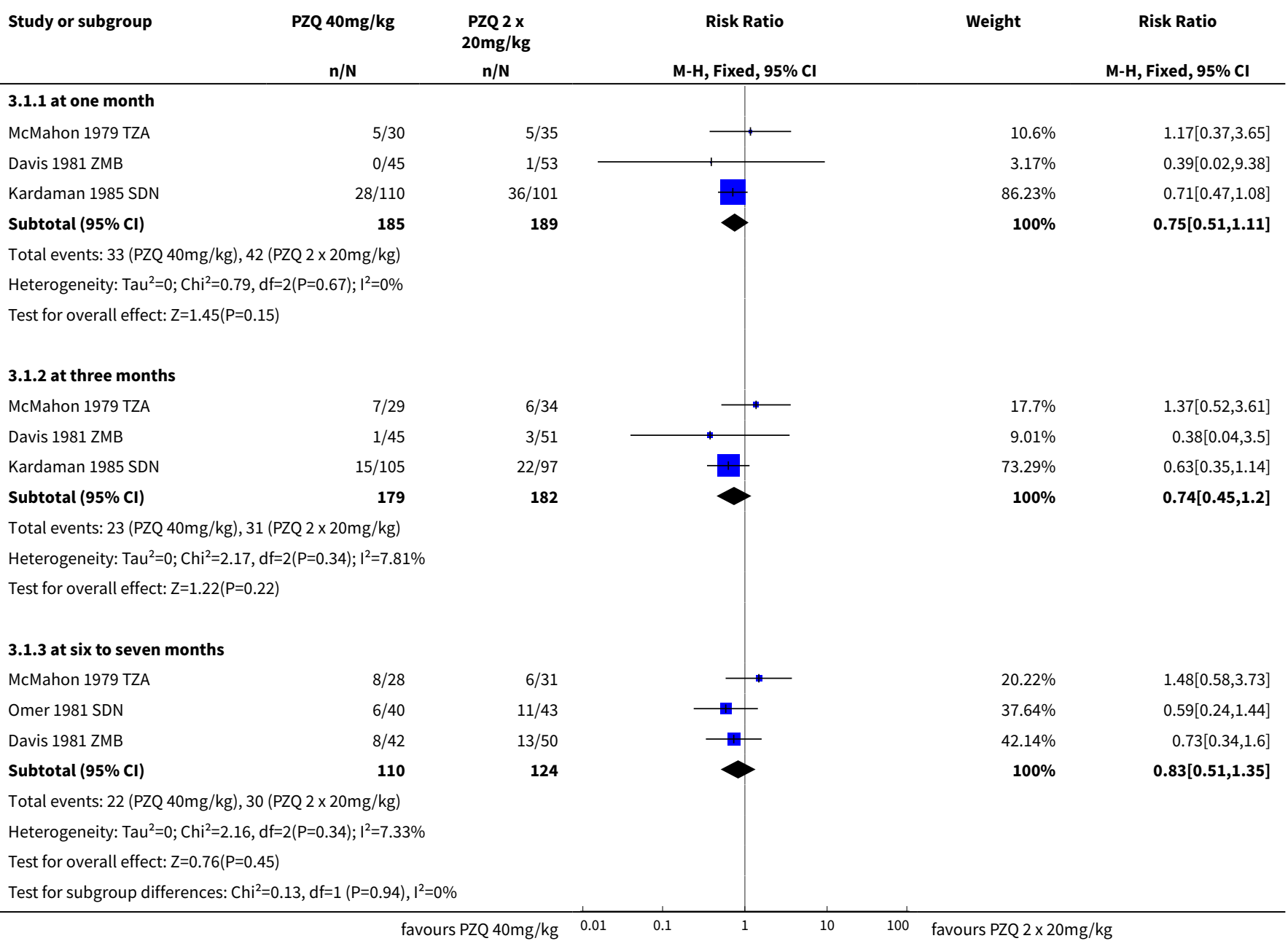

\section{Analysis 3.2. Comparison 3 Praziquantel $40 \mathrm{mg} / \mathrm{kg}$ single dose versus $2 \times 20 \mathrm{mg} / \mathrm{kg}$ split dose, Outcome 2 Adverse events.}

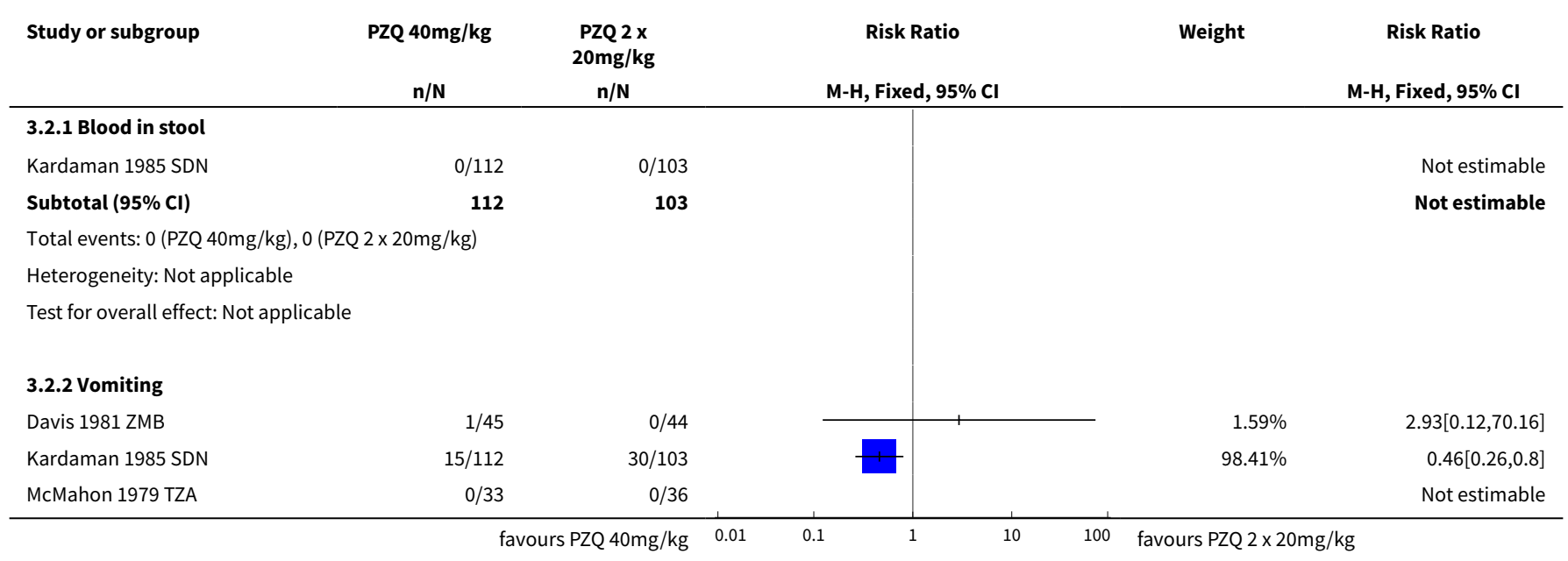

Drugs for treating urinary schistosomiasis (Review)

Copyright ( 2014 The Authors. Cochrane Database of Systematic Reviews published by John Wiley \& Sons, Ltd. on behalf of The Cochrane Collaboration. 


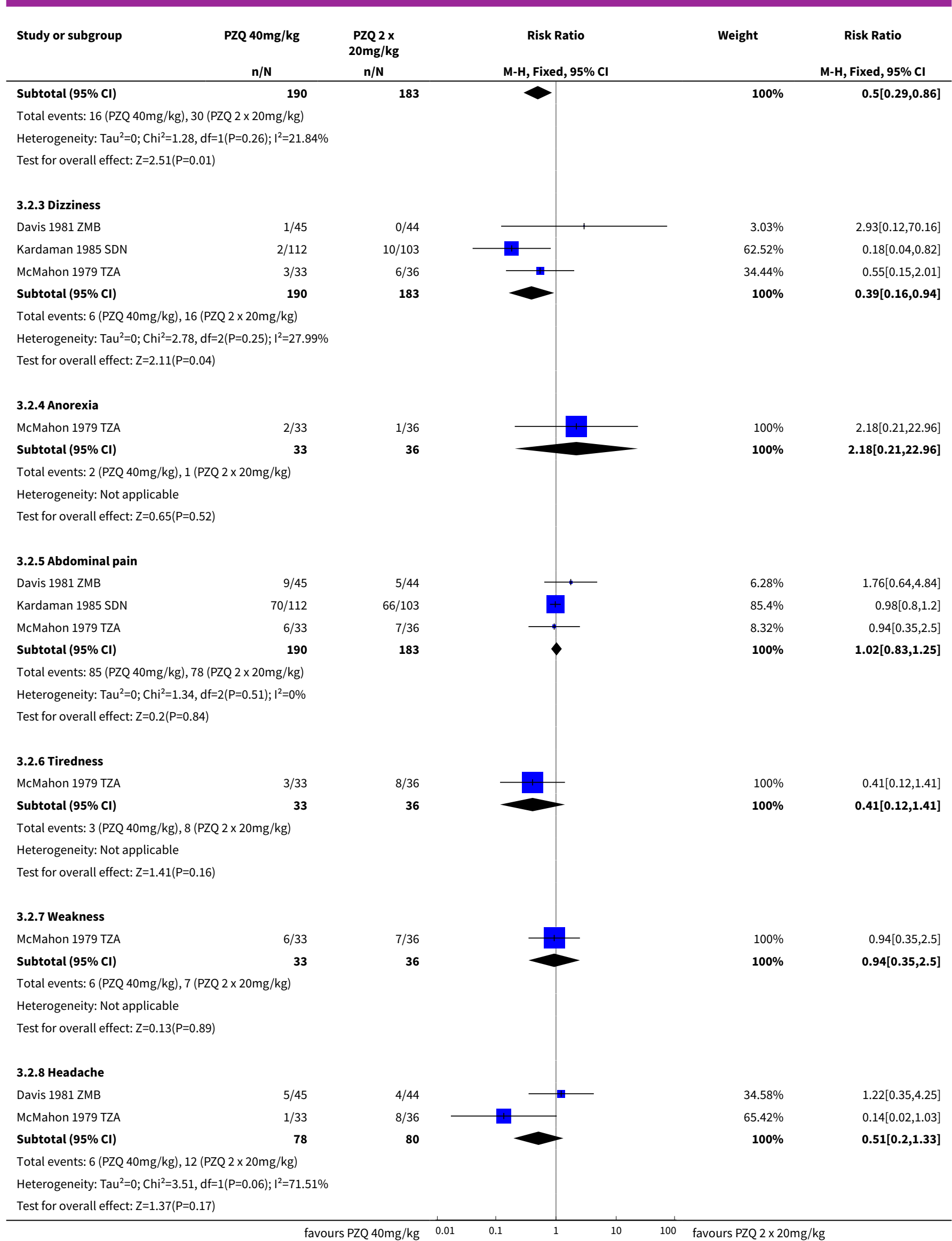

Drugs for treating urinary schistosomiasis (Review)

Copyright $\odot 2014$ The Authors. Cochrane Database of Systematic Reviews published by John Wiley \& Sons, Ltd. on behalf of The Cochrane Collaboration. 


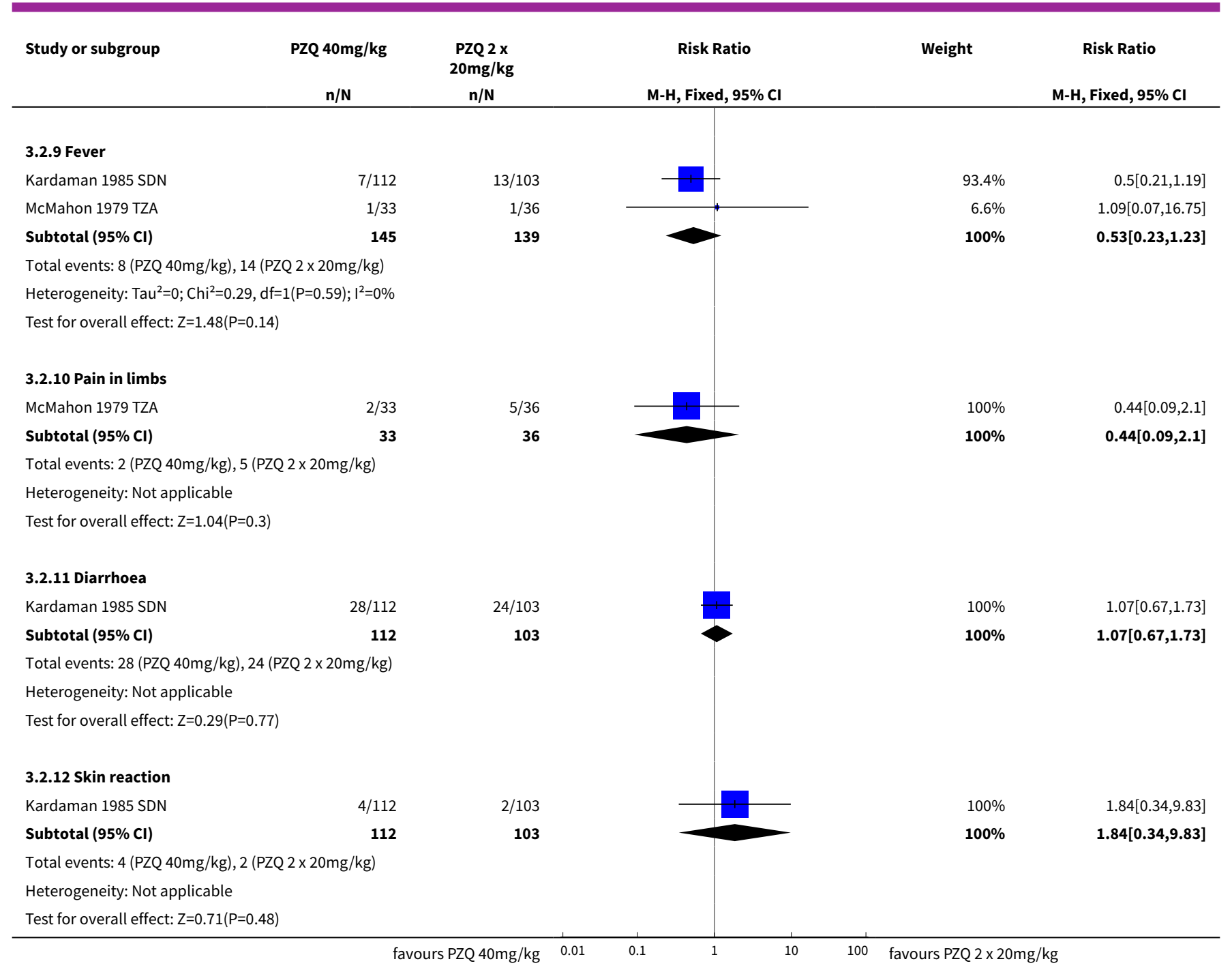

\section{Comparison 4. Praziquantel $40 \mathrm{mg} / \mathrm{kg}$ single dose versus praziquantel $2 \times 40 \mathrm{mg} / \mathrm{kg}$ or $3 \times 40 \mathrm{mg} / \mathrm{kg}$}

\begin{tabular}{|c|c|c|c|c|}
\hline Outcome or subgroup title & $\begin{array}{l}\text { No. of } \\
\text { studies }\end{array}$ & $\begin{array}{l}\text { No. of } \\
\text { partici- } \\
\text { pants }\end{array}$ & Statistical method & Effect size \\
\hline $\begin{array}{l}1 \text { Praziquantel } 40 \mathrm{mg} / \mathrm{single} \text { dose versus } \\
\text { praziquantel } 2 \times 40 \mathrm{mg} / \mathrm{kg} \text { : parasitological } \\
\text { failure }\end{array}$ & 2 & & Risk Ratio (M-H, Fixed, 95\% Cl) & Subtotals only \\
\hline 1.1 at six weeks & 1 & 269 & Risk Ratio (M-H, Fixed, 95\% Cl) & $0.82[0.50,1.34]$ \\
\hline 1.2 at nine weeks to three months & 2 & 686 & Risk Ratio (M-H, Fixed, 95\% Cl) & $1.06[0.91,1.25]$ \\
\hline 1.3 at six months & 1 & 556 & Risk Ratio (M-H, Fixed, 95\% Cl) & $1.12[0.95,1.31]$ \\
\hline $\begin{array}{l}2 \text { Praziquantel } 40 \mathrm{mg} / \mathrm{kg} \text { single dose versus } \\
\text { praziquantel } 3 \times 40 \mathrm{mg} / \mathrm{kg} \text { : parasitological } \\
\text { failure }\end{array}$ & 1 & & Risk Ratio (M-H, Fixed, 95\% Cl) & Subtotals only \\
\hline
\end{tabular}

Drugs for treating urinary schistosomiasis (Review) 


\begin{tabular}{llllll}
\hline Outcome or subgroup title & $\begin{array}{l}\text { No. of } \\
\text { studies }\end{array}$ & $\begin{array}{l}\text { No. of } \\
\text { partici- } \\
\text { pants }\end{array}$ & Statistical method & Effect size \\
\hline 2.1 at nine weeks & 1 & 185 & Risk Ratio (M-H, Fixed, 95\% Cl) & $0.94[0.42,2.12]$ \\
\hline $\begin{array}{l}3 \text { Praziquantel } 40 \mathrm{mg} / \mathrm{single} \text { dose versus } \\
\text { praziquantel } 2 \times 40 \mathrm{mg} / \mathrm{kg} \text { : microhaematuria } \\
\begin{array}{l}\text { at six months } \\
\hline\end{array}\end{array}$ & 1 & 300 & Risk Ratio (M-H, Fixed, 95\% Cl) & $1.17[0.88,1.56]$ \\
\hline
\end{tabular}

Analysis 4.1. Comparison 4 Praziquantel $40 \mathrm{mg} / \mathrm{kg}$ single dose versus praziquantel $2 \times 40 \mathrm{mg} / \mathrm{kg}$ or $3 \times 40$ $\mathrm{mg} / \mathrm{kg}$, Outcome 1 Praziquantel $40 \mathrm{mg} /$ single dose versus praziquantel $2 \times 40 \mathrm{mg} / \mathrm{kg}$ : parasitological failure.

\begin{tabular}{|c|c|c|c|c|c|}
\hline Study or subgroup & $\begin{array}{c}\text { PZQ 40mg/ } \\
\text { kg SD } \\
\text { n/N }\end{array}$ & $\begin{array}{c}\text { PZQ 2 x } \\
40 \mathrm{mg} / \mathrm{kg} \\
\mathrm{n} / \mathrm{N}\end{array}$ & $\begin{array}{c}\text { Risk Ratio } \\
\text { M-H, Fixed, 95\% Cl }\end{array}$ & Weight & $\begin{array}{c}\text { Risk Ratio } \\
\text { M-H, Fixed, 95\% Cl }\end{array}$ \\
\hline \multicolumn{6}{|l|}{ 4.1.1 at six weeks } \\
\hline Tchuente 2004 CMR & $23 / 135$ & $28 / 134$ & & $100 \%$ & $0.82[0.5,1.34]$ \\
\hline Subtotal $(95 \% \mathrm{Cl})$ & 135 & 134 & & $100 \%$ & $0.82[0.5,1.34]$ \\
\hline \multicolumn{6}{|c|}{ Total events: 23 (PZQ 40mg/kg SD), 28 (PZQ $2 \times 40$ mg/kg) } \\
\hline \multicolumn{6}{|c|}{ Heterogeneity: Not applicable } \\
\hline \multicolumn{6}{|c|}{ Test for overall effect: $\mathrm{Z}=0.8(\mathrm{P}=0.42)$} \\
\hline \multicolumn{6}{|c|}{ 4.1.2 at nine weeks to three months } \\
\hline Sacko $2009 \mathrm{MLI}$ & $94 / 150$ & $81 / 150$ & \# & $55.05 \%$ & $1.16[0.96,1.41]$ \\
\hline Sacko 2009 MLI & $60 / 139$ & $49 / 117$ & \# & $36.16 \%$ & $1.03[0.77,1.37]$ \\
\hline Tchuente 2004 CMR & $8 / 70$ & $12 / 60$ & $\longrightarrow$ & $8.78 \%$ & $0.57[0.25,1.3]$ \\
\hline Subtotal $(95 \% \mathrm{Cl})$ & 359 & 327 & 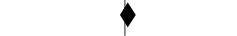 & $100 \%$ & $1.06[0.91,1.25]$ \\
\hline \multicolumn{6}{|c|}{ Total events: 162 (PZQ 40mg/kg SD), 142 (PZQ 2 × 40 mg/kg) } \\
\hline \multicolumn{6}{|c|}{ Heterogeneity: $\mathrm{Tau}^{2}=0 ; \mathrm{Chi}^{2}=3.02, \mathrm{df}=2(\mathrm{P}=0.22) ; \mathrm{I}^{2}=33.86 \%$} \\
\hline \multicolumn{6}{|c|}{ Test for overall effect: $\mathrm{Z}=0.74(\mathrm{P}=0.46)$} \\
\hline \multicolumn{6}{|l|}{ 4.1.3 at six months } \\
\hline Sacko 2009 MLI & $95 / 150$ & $81 / 150$ & \# & $60.35 \%$ & $1.17[0.97,1.42]$ \\
\hline Sacko 2009 MLI & $60 / 139$ & $49 / 117$ & \# & $39.65 \%$ & $1.03[0.77,1.37]$ \\
\hline Subtotal $(95 \% \mathrm{Cl})$ & 289 & 267 & $\bullet$ & $100 \%$ & $1.12[0.95,1.31]$ \\
\hline \multicolumn{6}{|c|}{ Total events: 155 (PZQ 40mg/kg SD), 130 (PZQ 2 × 40 mg/kg) } \\
\hline \multicolumn{6}{|c|}{ Heterogeneity: $\mathrm{Tau}^{2}=0 ; \mathrm{Chi}^{2}=0.55, \mathrm{df}=1(\mathrm{P}=0.46) ; \mathrm{I}^{2}=0 \%$} \\
\hline \multicolumn{6}{|c|}{ Test for overall effect: $Z=1.34(P=0.18)$} \\
\hline Test for subgroup dif & 42, $d f=1(P=0.49)$, & & & & \\
\hline
\end{tabular}

\section{Analysis 4.2. Comparison 4 Praziquantel $40 \mathrm{mg} / \mathrm{kg}$ single dose versus praziquantel $2 \times 40 \mathrm{mg} / \mathrm{kg}$ or $3 \times 40 \mathrm{mg} /$ $\mathrm{kg}$, Outcome 2 Praziquantel $40 \mathrm{mg} / \mathrm{kg}$ single dose versus praziquantel $3 \times 40 \mathrm{mg} / \mathrm{kg}$ : parasitological failure.}

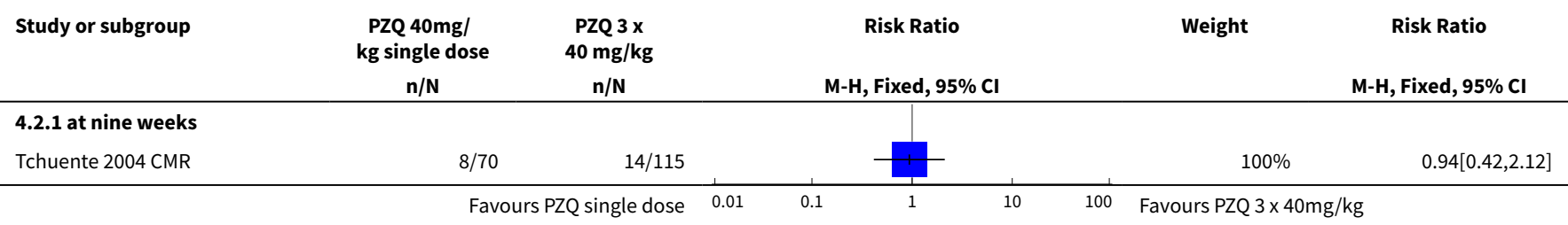




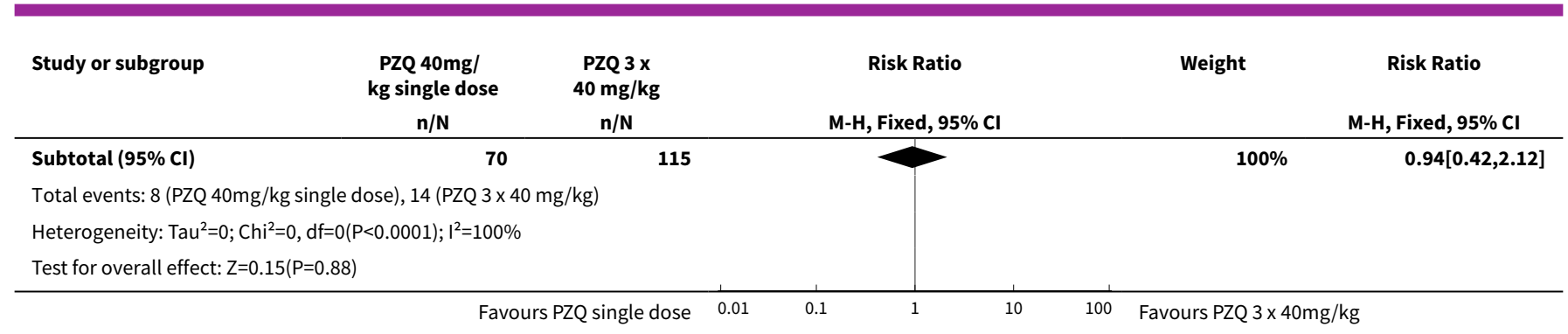

Analysis 4.3. Comparison 4 Praziquantel $40 \mathrm{mg} / \mathrm{kg}$ single dose versus praziquantel $2 \times 40 \mathrm{mg} / \mathrm{kg}$ or $3 \times 40 \mathrm{mg}$ / $\mathrm{kg}$, Outcome 3 Praziquantel $40 \mathrm{mg} / \mathrm{single}$ dose versus praziquantel $2 \times 40 \mathrm{mg} / \mathrm{kg}$ : microhaematuria at six months.

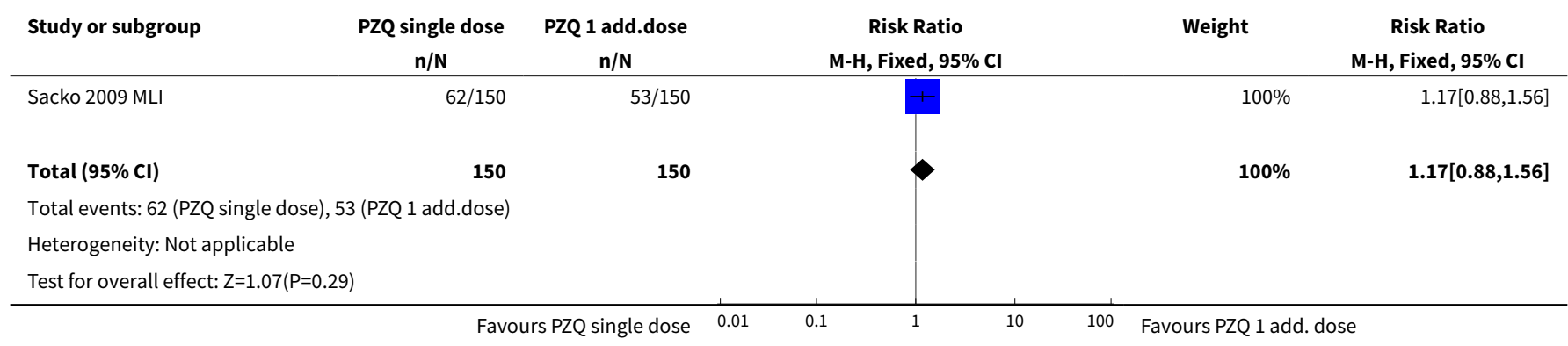

\section{Comparison 5. Praziquantel $40 \mathrm{mg} / \mathrm{kg}$ single dose versus multiple doses}

\begin{tabular}{lllll}
\hline Outcome or subgroup title & $\begin{array}{l}\text { No. of } \\
\text { studies }\end{array}$ & $\begin{array}{l}\text { No. of } \\
\text { partici- } \\
\text { pants }\end{array}$ & Statistical method & Effect size \\
\hline 1 Parasitological failure & 1 & & Risk Ratio (M-H, Fixed, 95\% Cl) & Subtotals only \\
\hline 1.1 at two years & 1 & 62 & Risk Ratio (M-H, Fixed, 95\% Cl) & $2.71[1.47,5.00]$ \\
\hline 1.2 at three years & 1 & 43 & Risk Ratio (M-H, Fixed, 95\% Cl) & $0.92[0.59,1.42]$ \\
\hline 2 Haematuria & 1 & 43 & Risk Ratio (M-H, Fixed, 95\% Cl) & $0.70[0.42,1.17]$ \\
\hline
\end{tabular}

Analysis 5.1. Comparison 5 Praziquantel $40 \mathrm{mg} / \mathrm{kg}$ single dose versus multiple doses, Outcome 1 Parasitological failure.

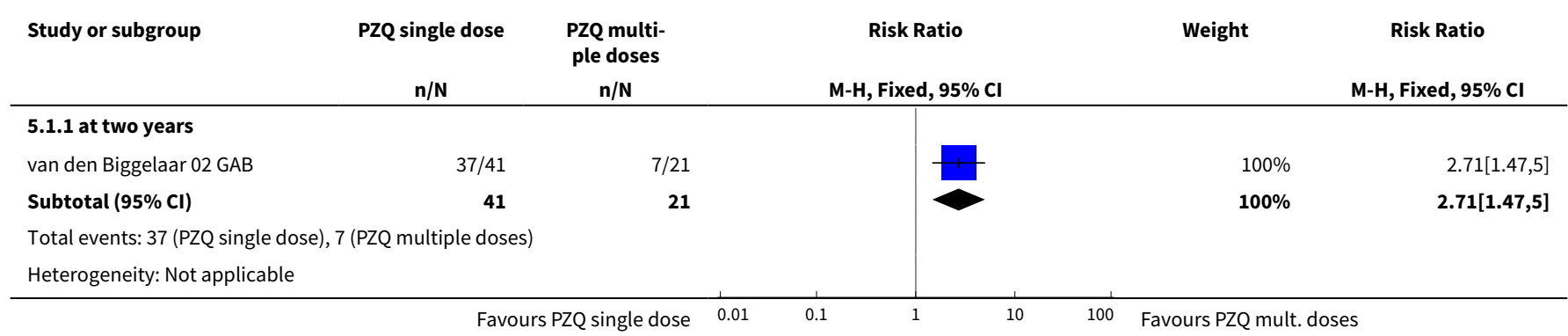




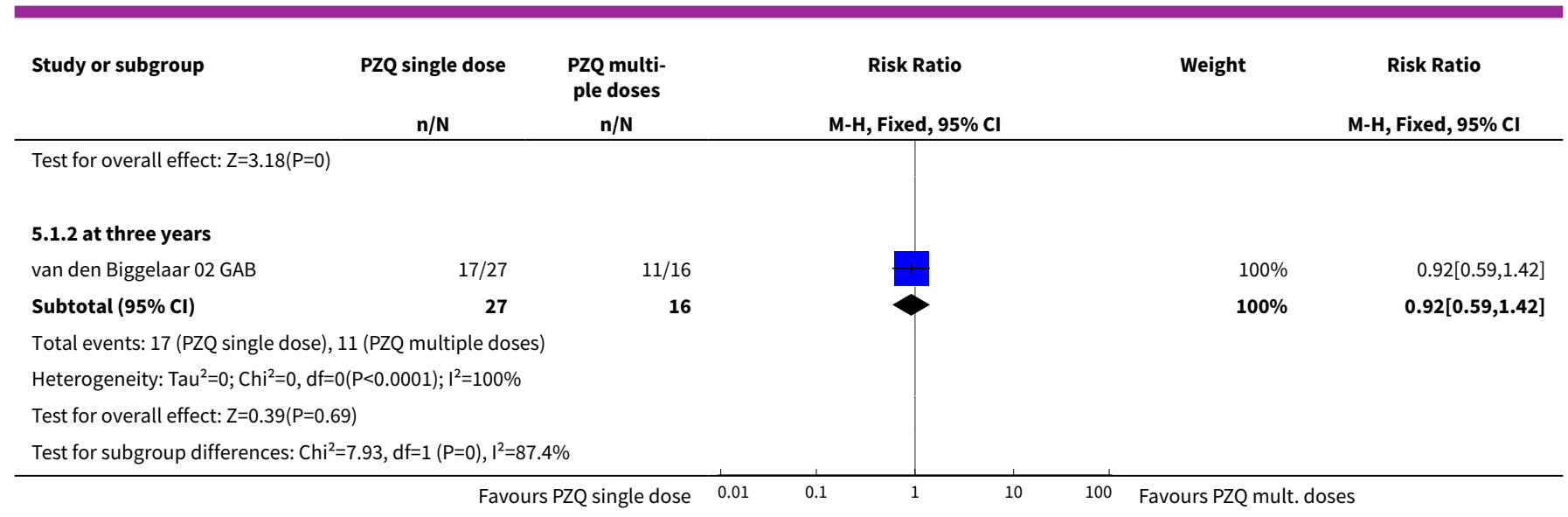

\section{Analysis 5.2. Comparison 5 Praziquantel $40 \mathrm{mg} / \mathrm{kg}$ single dose versus multiple doses, Outcome 2 Haematuria.}

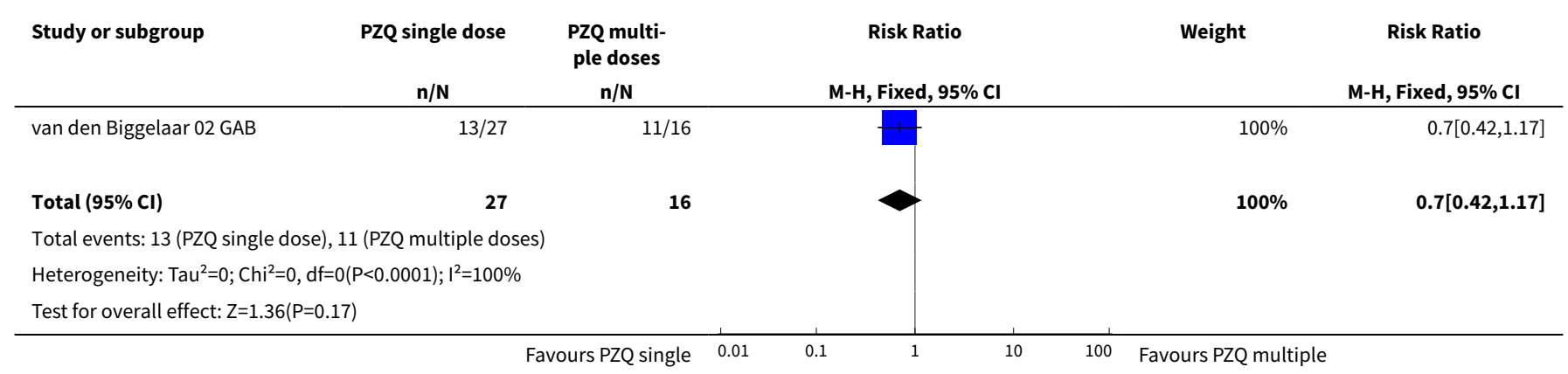

\section{Comparison 6. Metrifonate single dose $(10 \mathrm{mg} / \mathrm{kg})$ versus placebo}

\begin{tabular}{lllll}
\hline Outcome or subgroup title & $\begin{array}{l}\text { No. of } \\
\text { studies }\end{array}$ & $\begin{array}{l}\text { No. of } \\
\text { partici- } \\
\text { pants }\end{array}$ & Statistical method & Effect size \\
\hline 1 Parasitological failure & 2 & & Risk Ratio (M-H, Random, 95\% Cl) & Subtotals only \\
\hline 1.1 at one month & 1 & 142 & Risk Ratio (M-H, Random, 95\% Cl) & 0.83 [0.74, 0.94] \\
\hline $\begin{array}{lllll}1.2 \text { at two and a half to three } \\
\text { months }\end{array}$ & 1 & 122 & Risk Ratio (M-H, Random, 95\% Cl) & $0.92[0.85,0.99]$ \\
\hline 1.3 at six months & 1 & 102 & Risk Ratio (M-H, Random, 95\% Cl) & $0.94[0.87,1.02]$ \\
\hline 1.4 at eight months & 1 & 210 & Risk Ratio (M-H, Random, 95\% Cl) & 0.63 [0.54, 0.73] \\
\hline 2 Haemoglobin & 1 & & Mean Difference (IV, Fixed, 95\% Cl) & Subtotals only \\
\hline 2.1 at baseline & 1 & 207 & Mean Difference (IV, Fixed, 95\% Cl) & $0.0[-0.33,0.33]$ \\
\hline 2.2 at eight months & 1 & 207 & Mean Difference (IV, Fixed, 95\% Cl) & $0.30[-0.05,0.65]$ \\
\hline
\end{tabular}


Analysis 6.1. Comparison 6 Metrifonate single dose $(10 \mathrm{mg} / \mathrm{kg})$ versus placebo, Outcome 1 Parasitological failure.

\begin{tabular}{|c|c|c|c|c|c|}
\hline Study or subgroup & $\begin{array}{c}\text { Metrifonate } \\
n / N\end{array}$ & $\begin{array}{c}\text { Placebo } \\
n / N\end{array}$ & $\begin{array}{c}\text { Risk Ratio } \\
\text { M-H, Random, } 95 \% \mathrm{Cl}\end{array}$ & Weight & $\begin{array}{c}\text { Risk Ratio } \\
\text { M-H, Random, } 95 \% \mathrm{CI}\end{array}$ \\
\hline \multicolumn{6}{|l|}{ 6.1.1 at one month } \\
\hline Pugh 1983 MWI & $72 / 90$ & $50 / 52$ & & $100 \%$ & $0.83[0.74,0.94]$ \\
\hline Subtotal $(95 \% \mathrm{Cl})$ & 90 & 52 & $\checkmark$ & $100 \%$ & $0.83[0.74,0.94]$ \\
\hline \multicolumn{6}{|c|}{ Total events: 72 (Metrifonate), 50 (Placebo) } \\
\hline \multicolumn{6}{|c|}{ Heterogeneity: Not applicable } \\
\hline \multicolumn{6}{|c|}{ 6.1.2 at two and a half to three months } \\
\hline Pugh 1983 MWI & $75 / 82$ & $40 / 40$ & & $100 \%$ & $0.92[0.85,0.99]$ \\
\hline Subtotal $(95 \% \mathrm{CI})$ & 82 & 40 & 1 & $100 \%$ & $0.92[0.85,0.99]$ \\
\hline \multicolumn{6}{|c|}{ Total events: 75 (Metrifonate), 40 (Placebo) } \\
\hline \multicolumn{6}{|c|}{ Heterogeneity: Tau $^{2}=0 ; \mathrm{Chi}^{2}=0, \mathrm{df}=0(\mathrm{P}<0.0001) ; \mathrm{I}^{2}=100 \%$} \\
\hline \multicolumn{6}{|c|}{ Test for overall effect: $Z=2.13(P=0.03)$} \\
\hline \multicolumn{6}{|l|}{ 6.1.3 at six months } \\
\hline Pugh 1983 MWI & $67 / 72$ & $30 / 30$ & & $100 \%$ & $0.94[0.87,1.02]$ \\
\hline Subtotal $(95 \% \mathrm{Cl})$ & 72 & 30 & 1 & $100 \%$ & $0.94[0.87,1.02]$ \\
\hline \multicolumn{6}{|c|}{ Total events: 67 (Metrifonate), 30 (Placebo) } \\
\hline \multicolumn{6}{|c|}{ Heterogeneity: Not applicable } \\
\hline \multicolumn{6}{|c|}{ Test for overall effect: $Z=1.53(P=0.13)$} \\
\hline \multicolumn{6}{|l|}{ 6.1.4 at eight months } \\
\hline Stephenson 1989 KEN & $64 / 105$ & $102 / 105$ & & $100 \%$ & $0.63[0.54,0.73]$ \\
\hline Subtotal $(95 \% \mathrm{Cl})$ & 105 & 105 & $\diamond$ & $100 \%$ & $0.63[0.54,0.73]$ \\
\hline \multicolumn{6}{|c|}{ Total events: 64 (Metrifonate), 102 (Placebo) } \\
\hline \multicolumn{6}{|c|}{ Heterogeneity: Not applicable } \\
\hline Test for subgroup diffe & $82, \mathrm{df}=1(\mathrm{P}<0.000$ & $=86.85 \%$ & & & \\
\hline
\end{tabular}

\section{Analysis 6.2. Comparison 6 Metrifonate single dose $(10 \mathrm{mg} / \mathrm{kg})$ versus placebo, Outcome 2 Haemoglobin.}

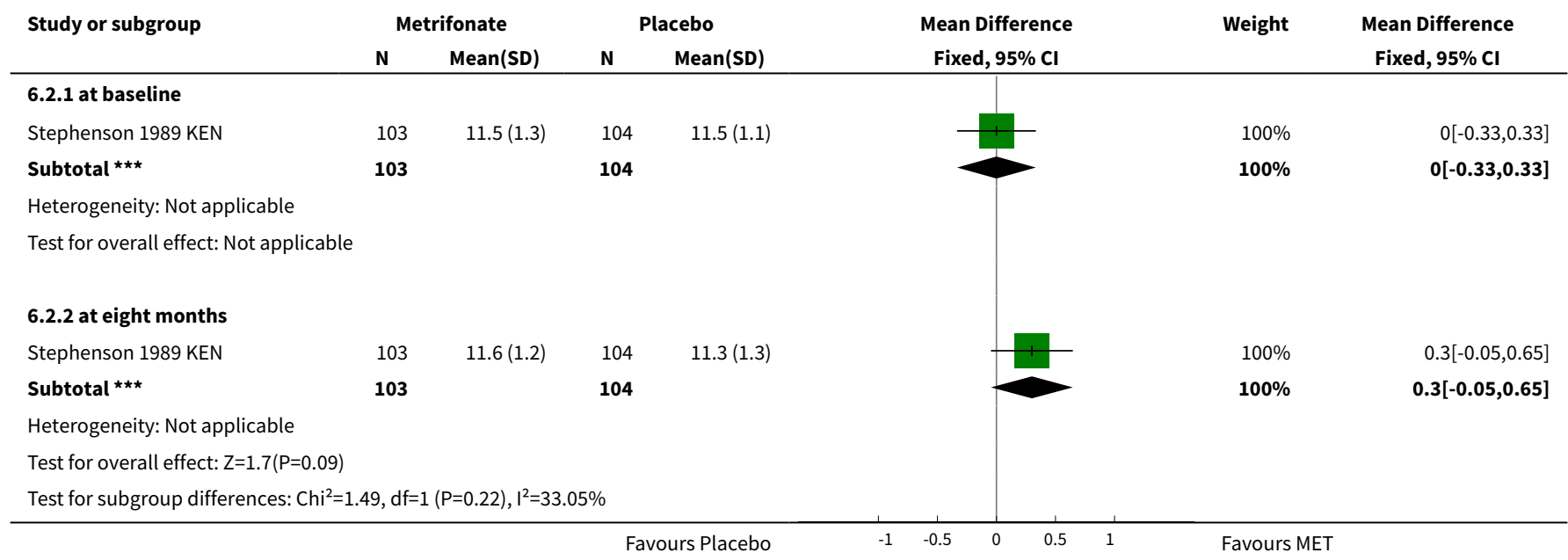

Drugs for treating urinary schistosomiasis (Review) 
Comparison 7. Metrifonate multiple doses versus placebo

\begin{tabular}{lllll}
\hline Outcome or subgroup title & $\begin{array}{l}\text { No. of } \\
\text { studies }\end{array}$ & $\begin{array}{l}\text { No. of } \\
\text { partici- } \\
\text { pants }\end{array}$ & Statistical method & Effect size \\
\hline 1 Parasitological failure & 3 & & Risk Ratio $(\mathrm{M}-\mathrm{H}$, Random, 95\% Cl) & Subtotals only \\
\hline 1.1 at one month & 1 & 50 & Risk Ratio $(\mathrm{M}-\mathrm{H}$, Random, $95 \% \mathrm{Cl})$ & $0.84[0.65,1.09]$ \\
\hline 1.2 at 11 weeks & 1 & 93 & Risk Ratio $(\mathrm{M}-\mathrm{H}$, Random, $95 \% \mathrm{Cl})$ & $0.41[0.30,0.56]$ \\
\hline 1.3 at five months & 1 & 51 & Risk Ratio (M-H, Random, 95\% Cl) & $0.89[0.76,1.03]$ \\
\hline 1.4 at six months & 1 & 400 & Risk Ratio (M-H, Random, 95\% Cl) & $0.30[0.24,0.37]$ \\
\hline 2 Haemoglobin & 1 & & Mean Difference (IV, Random, $95 \% \mathrm{Cl})$ & Subtotals only \\
\hline 2.1 at baseline & 1 & 400 & Mean Difference (IV, Random, $95 \% \mathrm{Cl})$ & $-0.17[-0.45,0.11]$ \\
\hline 2.2 at six months & 1 & 391 & Mean Difference (IV, Random, $95 \% \mathrm{Cl})$ & $0.30[0.14,0.46]$ \\
\hline
\end{tabular}

Analysis 7.1. Comparison 7 Metrifonate multiple doses versus placebo, Outcome 1 Parasitological failure.

\begin{tabular}{|c|c|c|c|c|c|}
\hline Study or subgroup & $\begin{array}{c}\text { Metrifonate } \\
\mathrm{n} / \mathrm{N}\end{array}$ & $\begin{array}{c}\text { Placebo } \\
\mathrm{n} / \mathrm{N}\end{array}$ & $\begin{array}{c}\text { Risk Ratio } \\
\text { M-H, Random, } 95 \% \mathrm{Cl}\end{array}$ & Weight & $\begin{array}{c}\text { Risk Ratio } \\
\text { M-H, Random, } 95 \% \mathrm{CI}\end{array}$ \\
\hline \multicolumn{6}{|l|}{ 7.1.1 at one month } \\
\hline de Jonge 1990 SDN & $24 / 32$ & $16 / 18$ & & $100 \%$ & $0.84[0.65,1.09]$ \\
\hline Subtotal $(95 \% \mathrm{Cl})$ & 32 & 18 & & $100 \%$ & $0.84[0.65,1.09]$ \\
\hline \multicolumn{6}{|c|}{ Total events: 24 (Metrifonate), 16 (Placebo) } \\
\hline \multicolumn{6}{|c|}{ Heterogeneity: Not applicable } \\
\hline \multicolumn{6}{|l|}{ 7.1.2 at 11 weeks } \\
\hline Jewsbury 1976 ZWE & $22 / 55$ & $38 / 38$ & & $100 \%$ & $0.41[0.3,0.56]$ \\
\hline Subtotal $(95 \% \mathrm{Cl})$ & 55 & 38 & & $100 \%$ & $0.41[0.3,0.56]$ \\
\hline \multicolumn{6}{|c|}{ Total events: 22 (Metrifonate), 38 (Placebo) } \\
\hline \multicolumn{6}{|c|}{ Heterogeneity: Not applicable } \\
\hline \multicolumn{6}{|l|}{ 7.1.3 at five months } \\
\hline de Jonge 1990 SDN & $28 / 32$ & $19 / 19$ & & $100 \%$ & $0.89[0.76,1.03]$ \\
\hline Subtotal $(95 \% \mathrm{Cl})$ & 32 & 19 & $\checkmark$ & $100 \%$ & $0.89[0.76,1.03]$ \\
\hline \multicolumn{6}{|c|}{ Total events: 28 (Metrifonate), 19 (Placebo) } \\
\hline \multicolumn{6}{|c|}{ Heterogeneity: Not applicable } \\
\hline \multicolumn{6}{|c|}{ Test for overall effect: $Z=1.56(P=0.12)$} \\
\hline \multicolumn{6}{|l|}{ 7.1.4 at six months } \\
\hline Stephenson 1985 KEN & $58 / 202$ & $190 / 198$ & & $100 \%$ & $0.3[0.24,0.37]$ \\
\hline Subtotal $(95 \% \mathrm{Cl})$ & 202 & 198 & & $100 \%$ & $0.3[0.24,0.37]$ \\
\hline \multicolumn{6}{|c|}{ Total events: 58 (Metrifonate), 190 (Placebo) } \\
\hline
\end{tabular}




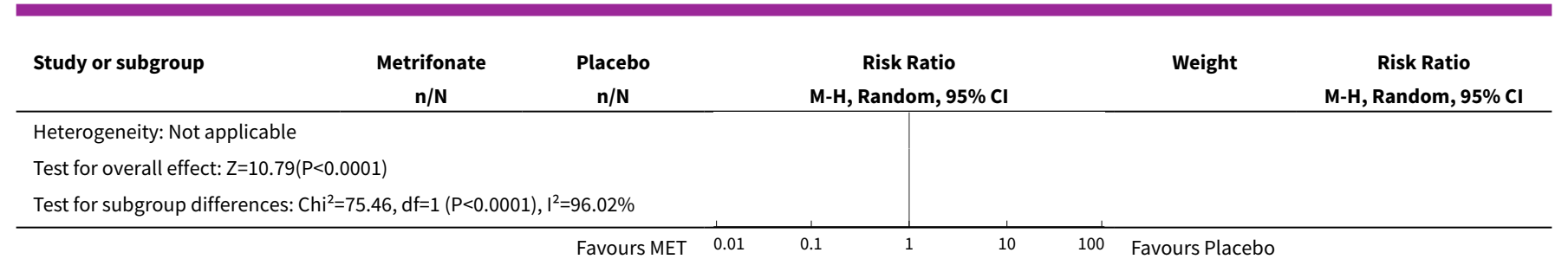

\section{Analysis 7.2. Comparison 7 Metrifonate multiple doses versus placebo, Outcome 2 Haemoglobin.}

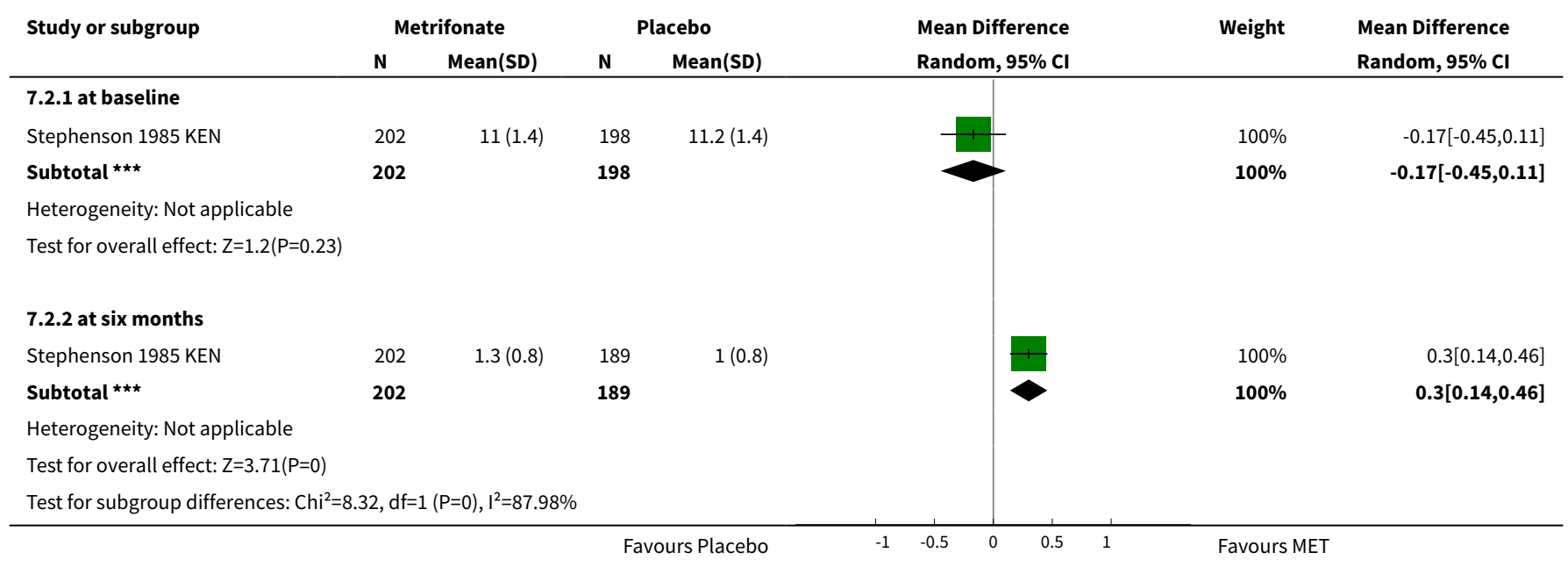

\section{Comparison 8. Metrifonate multiple doses versus single dose}

\begin{tabular}{lllll}
\hline Outcome or subgroup title & $\begin{array}{l}\text { No. of } \\
\text { studies }\end{array}$ & $\begin{array}{l}\text { No. of } \\
\text { partici- } \\
\text { pants }\end{array}$ & Statistical method & Effect size \\
\hline $\begin{array}{l}1 \text { Parasitological failure at one } \\
\text { month }\end{array}$ & 1 & & Risk Ratio $(\mathrm{M}-\mathrm{H}$, Fixed, $95 \% \mathrm{Cl})$ & Subtotals only \\
\hline $1.120 \mathrm{mg} / \mathrm{kg}$ versus $10 \mathrm{mg} / \mathrm{kg}$ & 1 & 112 & Risk Ratio $(\mathrm{M}-\mathrm{H}$, Fixed, $95 \% \mathrm{Cl})$ & $0.75[0.50,1.13]$ \\
\hline $1.230 \mathrm{mg} / \mathrm{kg}$ versus $10 \mathrm{mg} / \mathrm{kg}$ & 1 & 93 & Risk Ratio $(\mathrm{M}-\mathrm{H}$, Fixed, $95 \% \mathrm{Cl})$ & $0.36[0.17,0.77]$ \\
\hline 2 Parasitological failure at four & 1 & & Risk Ratio (M-H, Fixed, $95 \% \mathrm{Cl})$ & Subtotals only \\
\hline $\begin{array}{l}\text { months } \\
2.120 \mathrm{mg} / \mathrm{kg} \text { versus } 10 \mathrm{mg} / \mathrm{kg}\end{array}$ & 1 & 133 & Risk Ratio (M-H, Fixed, $95 \% \mathrm{Cl})$ & $0.78[0.58,1.06]$ \\
\hline $2.230 \mathrm{mg} / \mathrm{kg}$ versus $10 \mathrm{mg} / \mathrm{kg}$ & 1 & 111 & Risk Ratio $(\mathrm{M}-\mathrm{H}$, Fixed, $95 \% \mathrm{Cl})$ & $0.67[0.45,0.99]$ \\
\hline
\end{tabular}


Analysis 8.1. Comparison 8 Metrifonate multiple doses versus single dose, Outcome 1 Parasitological failure at one month.

\begin{tabular}{|c|c|c|c|c|c|}
\hline Study or subgroup & $\begin{array}{c}\text { Higher dose } \\
n / N\end{array}$ & $\begin{array}{c}10 \mathrm{mg} / \mathrm{kg} \\
\mathrm{n} / \mathrm{N}\end{array}$ & $\begin{array}{c}\text { Risk Ratio } \\
\text { M-H, Fixed, 95\% Cl }\end{array}$ & Weight & $\begin{array}{c}\text { Risk Ratio } \\
\text { M-H, Fixed, 95\% Cl }\end{array}$ \\
\hline \multicolumn{6}{|c|}{$8.1 .120 \mathrm{mg} / \mathrm{kg}$ versus $10 \mathrm{mg} / \mathrm{kg}$} \\
\hline Rey 1984 NER & $20 / 50$ & $33 / 62$ & & $100 \%$ & $0.75[0.5,1.13]$ \\
\hline Subtotal $(95 \% \mathrm{Cl})$ & 50 & 62 & & $100 \%$ & $0.75[0.5,1.13]$ \\
\hline \multicolumn{6}{|c|}{ Total events: 20 (Higher dose), 33 (10 mg/kg) } \\
\hline \multicolumn{6}{|c|}{ Heterogeneity: Not applicable } \\
\hline \multicolumn{6}{|c|}{$8.1 .230 \mathrm{mg} / \mathrm{kg}$ versus $10 \mathrm{mg} / \mathrm{kg}$} \\
\hline Rey 1984 NER & $6 / 31$ & $33 / 62$ & & $100 \%$ & $0.36[0.17,0.77]$ \\
\hline Subtotal $(95 \% \mathrm{Cl})$ & 31 & 62 & & $100 \%$ & $0.36[0.17,0.77]$ \\
\hline \multicolumn{6}{|c|}{ Total events: 6 (Higher dose), 33 (10 mg/kg) } \\
\hline \multicolumn{6}{|c|}{ Heterogeneity: Not applicable } \\
\hline \multicolumn{6}{|c|}{ Test for subgroup differences: $\mathrm{Chi}^{2}=2.73, \mathrm{df}=1(\mathrm{P}=0.1), \mathrm{I}^{2}=63.42 \%$} \\
\hline
\end{tabular}

Analysis 8.2. Comparison 8 Metrifonate multiple doses versus single dose, Outcome 2 Parasitological failure at four months.

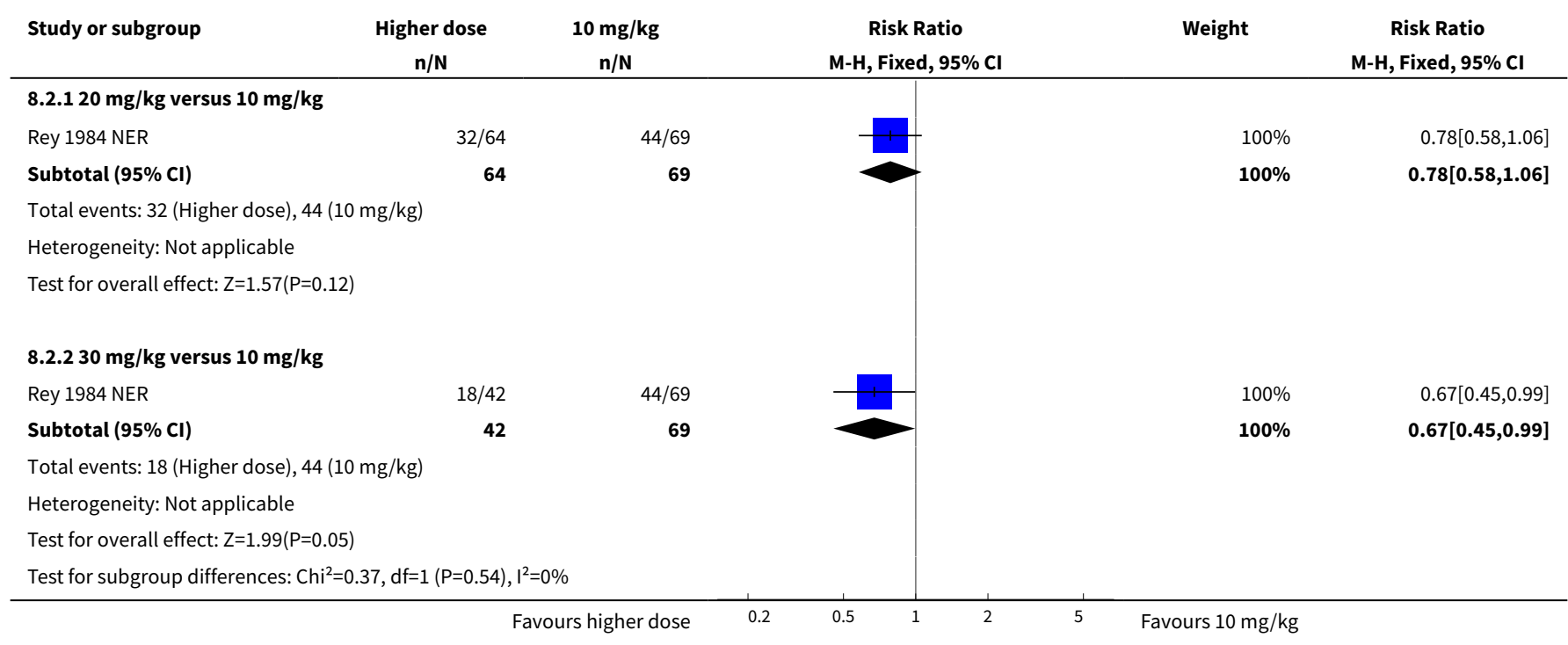

Comparison 9. Metrifonate 3 doses 2 weeks apart: $7.5 \mathrm{mg} / \mathrm{kg}$ versus $5 \mathrm{mg} / \mathrm{kg}$

\begin{tabular}{lllll}
\hline Outcome or subgroup title & $\begin{array}{l}\text { No. of } \\
\text { studies }\end{array}$ & $\begin{array}{l}\text { No. of } \\
\text { partici- } \\
\text { pants }\end{array}$ & Statistical method & Effect size \\
\hline 1 Parasitological failure & 1 & & Risk Ratio (M-H, Fixed, $95 \% \mathrm{Cl})$ & Subtotals only \\
\hline
\end{tabular}




\begin{tabular}{|c|c|c|c|c|}
\hline Outcome or subgroup title & $\begin{array}{l}\text { No. of } \\
\text { studies }\end{array}$ & $\begin{array}{l}\text { No. of } \\
\text { partici- } \\
\text { pants }\end{array}$ & Statistical method & Effect size \\
\hline 1.1 at one month & 1 & 201 & Risk Ratio (M-H, Fixed, 95\% Cl) & $0.91[0.69,1.21]$ \\
\hline 1.2 at two months & 1 & 165 & Risk Ratio (M-H, Fixed, 95\% Cl) & $0.97[0.72,1.30]$ \\
\hline 1.3 at three months & 1 & 133 & Risk Ratio (M-H, Fixed, 95\% Cl) & $0.92[0.67,1.26]$ \\
\hline 1.4 at six months & 1 & 139 & Risk Ratio (M-H, Fixed, 95\% Cl) & $1.43[0.99,2.05]$ \\
\hline 2 Adverse events & 1 & & Risk Ratio (M-H, Fixed, 95\% Cl) & Subtotals only \\
\hline 2.1 Nausea & 1 & 201 & Risk Ratio (M-H, Fixed, 95\% Cl) & $0.51[0.05,5.48]$ \\
\hline 2.2 Vomiting & 1 & 201 & Risk Ratio (M-H, Fixed, 95\% Cl) & $1.01[0.06,15.93]$ \\
\hline 2.3 Dizziness & 1 & 201 & Risk Ratio (M-H, Fixed, 95\% Cl) & $1.01[0.06,15.93]$ \\
\hline 2.4 Abdominal pain & 1 & 201 & Risk Ratio (M-H, Fixed, 95\% Cl) & $3.03[0.32,28.64]$ \\
\hline 2.5 Headache & 1 & 201 & Risk Ratio (M-H, Fixed, 95\% Cl) & $0.34[0.04,3.18]$ \\
\hline 2.6 Heaviness of the tongue & 1 & 201 & Risk Ratio (M-H, Fixed, 95\% Cl) & $2.02[0.19,21.92]$ \\
\hline
\end{tabular}

\section{Analysis 9.1. Comparison 9 Metrifonate 3 doses 2 weeks apart: $7.5 \mathrm{mg} / \mathrm{kg}$ versus $5 \mathrm{mg} / \mathrm{kg}$, Outcome 1 Parasitological failure.}

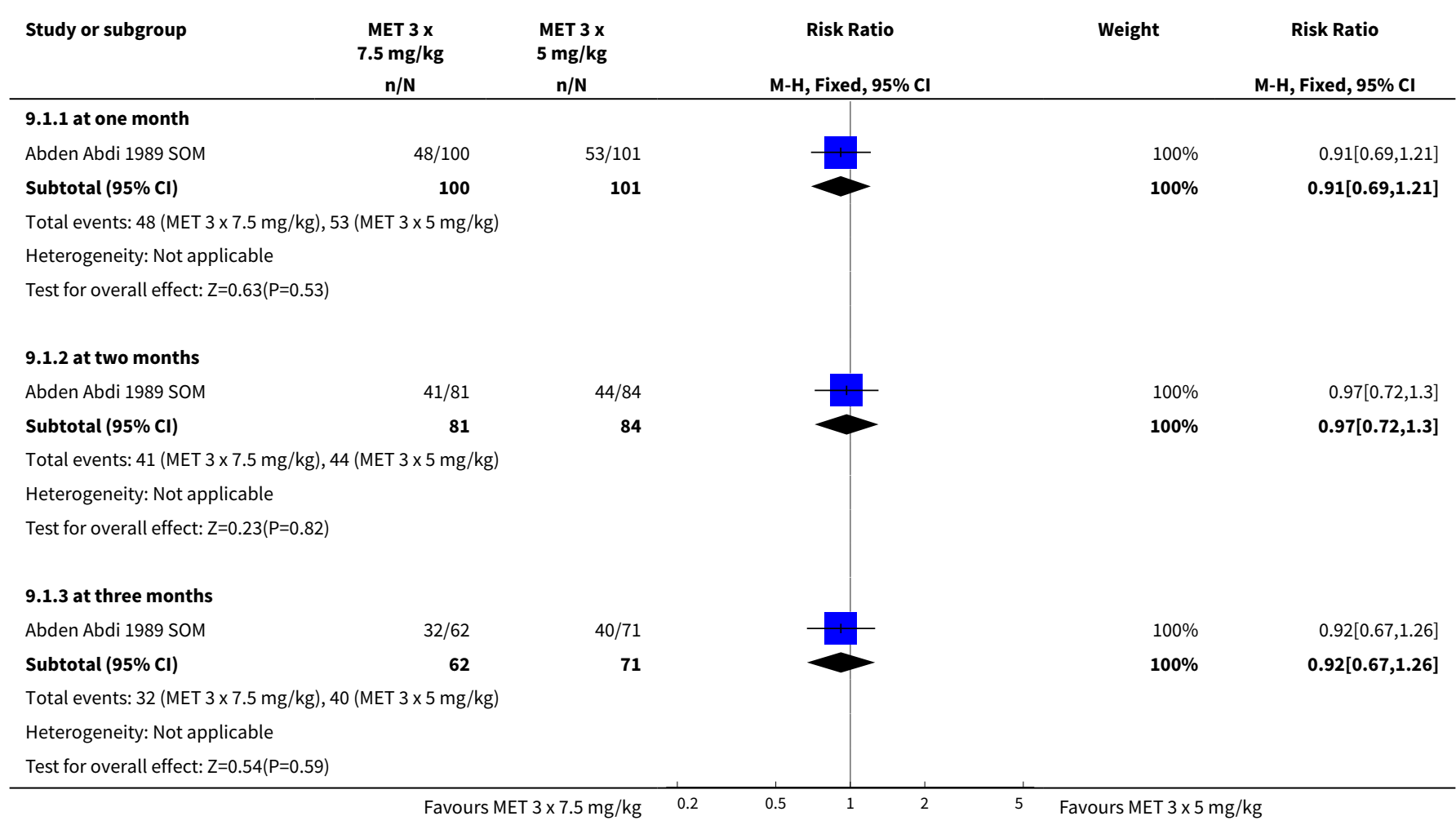




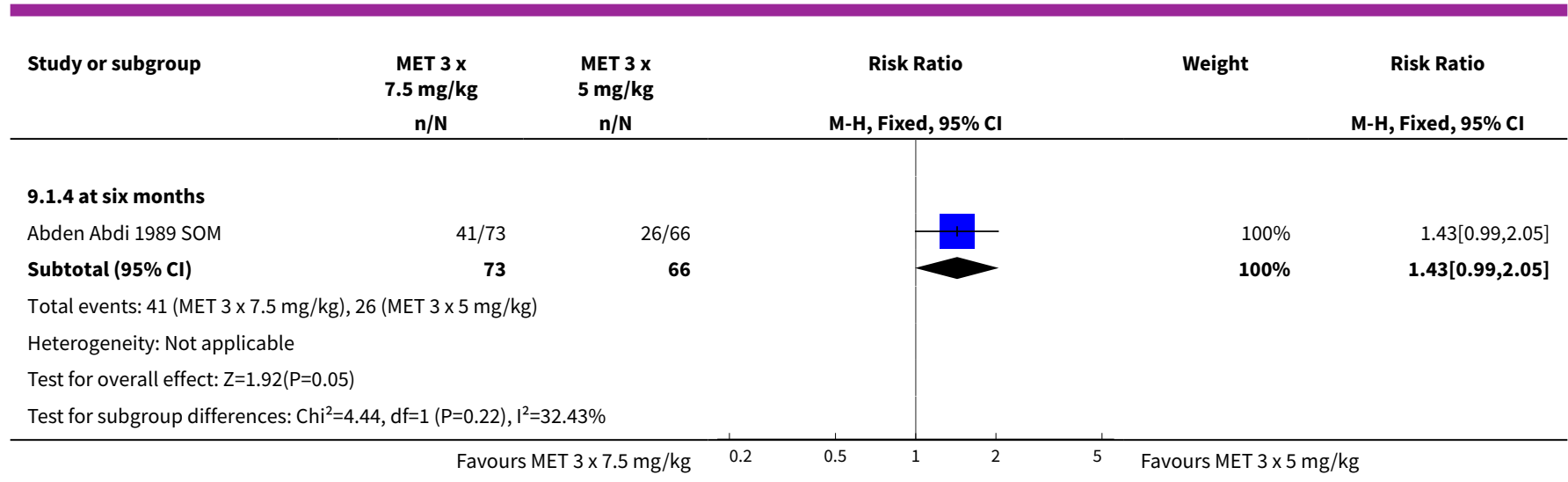

Analysis 9.2. Comparison 9 Metrifonate 3 doses 2 weeks apart: $7.5 \mathrm{mg} / \mathrm{kg}$ versus $5 \mathrm{mg} / \mathrm{kg}$, Outcome 2 Adverse events.

\begin{tabular}{ccccc} 
Study or subgroup & $\begin{array}{c}\text { Metrifonate } \\
7.5 \mathrm{mg} / \mathrm{kg}\end{array}$ & $\begin{array}{c}\text { Metrifonate } \\
5 \mathrm{mg} / \mathrm{kg}\end{array}$ & Risk Ratio & Weight \\
& $\mathrm{n} / \mathrm{N}$ & $\mathrm{n} / \mathrm{N}$ & $\mathrm{M}-\mathrm{H}, \mathrm{Fixed}, 95 \% \mathrm{Cl}$ & $\mathrm{M}-\mathrm{H}, \mathrm{Fixed}, 95 \% \mathrm{Cl}$ \\
\hline
\end{tabular}

$\begin{array}{lrr}\text { 9.2.1 Nausea } & & \\ \text { Abden Abdi } 1989 \text { SOM } & 1 / 100 & 2 / 101 \\ \text { Subtotal }(\mathbf{9 5} \% \mathrm{Cl}) & \mathbf{1 0 0} & \mathbf{1 0 1}\end{array}$

Total events: 1 (Metrifonate $7.5 \mathrm{mg} / \mathrm{kg}$ ), 2 (Metrifonate $5 \mathrm{mg} / \mathrm{kg}$ )

$2 / 101$

101

Heterogeneity: Not applicable

Test for overall effect: $\mathrm{Z}=0.56(\mathrm{P}=0.57)$

\subsubsection{Vomiting}

Abden Abdi 1989 SOM

Subtotal $(95 \% \mathrm{Cl})$

$1 / 100$

100

$1 / 101$

101

Total events: 1 (Metrifonate 7.5 mg/kg), 1 (Metrifonate 5 mg/kg)

Heterogeneity: Not applicable

Test for overall effect: $\mathrm{Z}=0.01(\mathrm{P}=0.99)$

\subsubsection{Dizziness}

Abden Abdi 1989 SOM

$1 / 100$

Subtotal $(95 \% \mathrm{CI})$

100

Total events: 1 (Metrifonate $7.5 \mathrm{mg} / \mathrm{kg}$ ), 1 (Metrifonate $5 \mathrm{mg} / \mathrm{kg}$ )

Heterogeneity: Not applicable

Test for overall effect: $Z=0.01(P=0.99)$

\subsubsection{Abdominal pain}

Abden Abdi 1989 SOM

Subtotal $(95 \% \mathrm{Cl})$

\section{$3 / 100$}

100

Total events: 3 (Metrifonate $7.5 \mathrm{mg} / \mathrm{kg}$ ), 1 (Metrifonate $5 \mathrm{mg} / \mathrm{kg}$ )

Heterogeneity: Not applicable

Test for overall effect: $\mathrm{Z}=0.97(\mathrm{P}=0.33)$

\subsubsection{Headache}

Abden Abdi 1989 SOM

Subtotal $(95 \% \mathrm{Cl})$

$1 / 100$

100

Total events: 1 (Metrifonate $7.5 \mathrm{mg} / \mathrm{kg}$ ), 3 (Metrifonate $5 \mathrm{mg} / \mathrm{kg}$ )

Heterogeneity: Not applicable

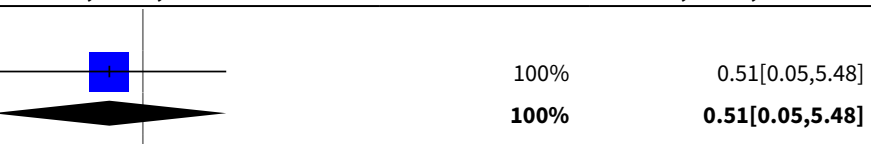

$0.51[0.05,5.48]$
$\mathbf{0 . 5 1}[\mathbf{0 . 0 5 , 5 . 4 8}]$

$100 \%$

$100 \%$

$1.01[0.06,15.93]$

$1.01[0.06,15.93]$ 


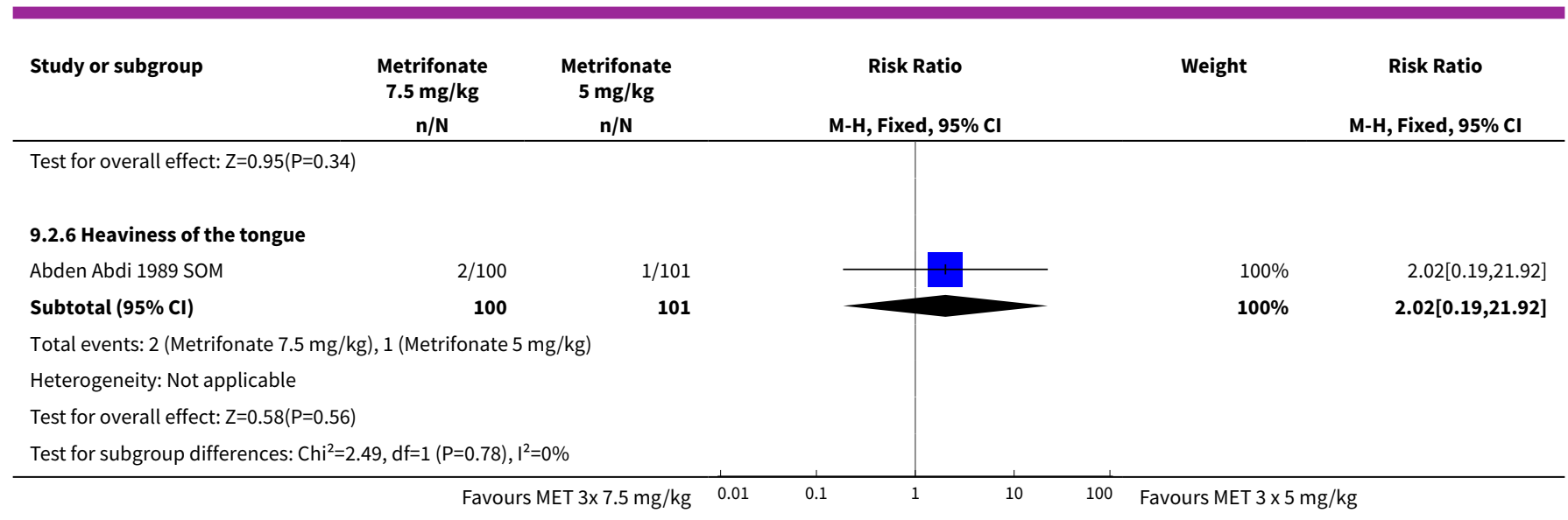

\section{Comparison 10. Praziquantel versus metrifonate}

\begin{tabular}{|c|c|c|c|c|}
\hline Outcome or subgroup title & $\begin{array}{l}\text { No. of } \\
\text { studies }\end{array}$ & $\begin{array}{l}\text { No. of } \\
\text { partici- } \\
\text { pants }\end{array}$ & Statistical method & Effect size \\
\hline $\begin{array}{l}1 \text { Praziquantel } 40 \mathrm{mg} / \mathrm{kg} \text { sin- } \\
\text { gle dose versus metrifonate } \\
10 \mathrm{mg} / \mathrm{kg} \text { single dose: para- } \\
\text { sitological failure }\end{array}$ & 3 & & Risk Ratio (M-H, Fixed, 95\% Cl) & Subtotals only \\
\hline 1.1 at one month & 1 & 183 & Risk Ratio (M-H, Fixed, 95\% Cl) & $0.46[0.34,0.61]$ \\
\hline 1.2 at two to three months & 2 & 243 & Risk Ratio (M-H, Fixed, 95\% Cl) & $0.67[0.57,0.79]$ \\
\hline 1.3 at six months & 1 & 149 & Risk Ratio (M-H, Fixed, 95\% Cl) & $0.89[0.79,1.01]$ \\
\hline 1.4 at eight months & 1 & 208 & Risk Ratio (M-H, Fixed, 95\% Cl) & $0.21[0.13,0.36]$ \\
\hline $\begin{array}{l}2 \text { Praziquantel } 40 \mathrm{mg} / \mathrm{kg} \\
\text { single dose versus metri- } \\
\text { fonate } 10 \mathrm{mg} / \mathrm{kg} \text { single dose: } \\
\text { haemoglobin }\end{array}$ & 1 & & Mean Difference (IV, Fixed, 95\% CI) & Subtotals only \\
\hline 2.1 at baseline & 1 & 208 & Mean Difference (IV, Fixed, 95\% CI) & $-0.30[-0.52,-0.08]$ \\
\hline 2.2 at eight months & 1 & 208 & Mean Difference (IV, Fixed, 95\% CI) & $-0.40[-0.66,-0.14]$ \\
\hline $\begin{array}{l}3 \text { Praziquantel } 40 \mathrm{mg} / \mathrm{kg} \text { sin- } \\
\text { gle dose versus metrifonate } \\
20 \text { and } 30 \mathrm{mg} / \mathrm{kg} \text { given as } \\
\text { split doses: parasitological } \\
\text { failure }\end{array}$ & 2 & & Risk Ratio (M-H, Random, 95\% Cl) & Subtotals only \\
\hline $\begin{array}{l}3.12 \times 10 \mathrm{mg} / \mathrm{kg} \text { Metrifonate } \\
\text { at one month }\end{array}$ & 1 & 72 & Risk Ratio (M-H, Random, 95\% Cl) & $1.03[0.80,1.34]$ \\
\hline $\begin{array}{l}3.22 \times 10 \mathrm{mg} / \mathrm{kg} \text { Metrifonate } \\
\text { at five months }\end{array}$ & 1 & 67 & Risk Ratio (M-H, Random, 95\% Cl) & $0.82[0.64,1.05]$ \\
\hline
\end{tabular}




\begin{tabular}{|c|c|c|c|c|}
\hline Outcome or subgroup title & $\begin{array}{l}\text { No. of } \\
\text { studies }\end{array}$ & $\begin{array}{l}\text { No. of } \\
\text { partici- } \\
\text { pants }\end{array}$ & Statistical method & Effect size \\
\hline $\begin{array}{l}3.33 \times 10 \mathrm{mg} / \mathrm{kg} \text { Metrifonate } \\
\text { at three months }\end{array}$ & 1 & 100 & Risk Ratio (M-H, Random, 95\% Cl) & $0.33[0.07,1.57]$ \\
\hline $\begin{array}{l}3.43 \times 10 \mathrm{mg} / \mathrm{kg} \text { Metrifonate } \\
\text { at six months }\end{array}$ & 1 & 100 & Risk Ratio (M-H, Random, 95\% Cl) & $0.2[0.02,1.65]$ \\
\hline $\begin{array}{l}4 \text { Praziquantel } 40 \mathrm{mg} / \mathrm{kg} \text { sin- } \\
\text { gle dose versus metrifonate } \\
30 \mathrm{mg} / \mathrm{kg} \text { given as split dose: } \\
\text { adverse events }\end{array}$ & 1 & & Risk Ratio (M-H, Fixed, 95\% Cl) & Totals not selected \\
\hline 4.1 Dizziness & 1 & & Risk Ratio (M-H, Fixed, 95\% Cl) & $0.0[0.0,0.0]$ \\
\hline 4.2 Abdominal pain & 1 & & Risk Ratio (M-H, Fixed, 95\% CI) & $0.0[0.0,0.0]$ \\
\hline 4.3 Joint pain & 1 & & Risk Ratio (M-H, Fixed, 95\% Cl) & $0.0[0.0,0.0]$ \\
\hline 4.4 Nausea & 1 & & Risk Ratio (M-H, Fixed, 95\% Cl) & $0.0[0.0,0.0]$ \\
\hline 4.5 Rash & 1 & & Risk Ratio (M-H, Fixed, 95\% Cl) & $0.0[0.0,0.0]$ \\
\hline 4.6 Vomiting & 1 & & Risk Ratio (M-H, Fixed, 95\% CI) & $0.0[0.0,0.0]$ \\
\hline 4.7 Itching & 1 & & Risk Ratio (M-H, Fixed, 95\% Cl) & $0.0[0.0,0.0]$ \\
\hline 4.8 Fatigue & 1 & & Risk Ratio (M-H, Fixed, 95\% Cl) & $0.0[0.0,0.0]$ \\
\hline 4.9 Hair loss & 1 & & Risk Ratio (M-H, Fixed, 95\% Cl) & $0.0[0.0,0.0]$ \\
\hline 4.10 Change in taste & 1 & & Risk Ratio (M-H, Fixed, 95\% Cl) & $0.0[0.0,0.0]$ \\
\hline 4.11 Diarrhoea & 1 & & Risk Ratio (M-H, Fixed, 95\% Cl) & $0.0[0.0,0.0]$ \\
\hline 4.12 Convulsion & 1 & & Risk Ratio (M-H, Fixed, 95\% Cl) & $0.0[0.0,0.0]$ \\
\hline $\begin{array}{l}5 \text { Praziquantel } 30 \mathrm{mg} / \mathrm{kg} \text { sin- } \\
\text { gle dose versus metrifonate } \\
30 \mathrm{mg} / \mathrm{kg} \text { given as split dose: } \\
\text { parasitological failure }\end{array}$ & 1 & & Risk Ratio (M-H, Fixed, 95\% Cl) & Subtotals only \\
\hline 5.1 at two months & 1 & 54 & Risk Ratio (M-H, Fixed, 95\% Cl) & $0.53[0.17,1.68]$ \\
\hline 5.2 at four months & 1 & 52 & Risk Ratio (M-H, Fixed, 95\% Cl) & $0.24[0.07,0.80]$ \\
\hline $\begin{array}{l}6 \text { Praziquantel } 30 \mathrm{mg} / \mathrm{kg} \text { sin- } \\
\text { gle dose versus metrifonate } \\
30 \mathrm{mg} / \mathrm{kg} \text { given as split dose: } \\
\text { adverse events }\end{array}$ & 1 & & Risk Ratio (M-H, Fixed, 95\% Cl) & Subtotals only \\
\hline 6.1 Nausea & 1 & 60 & Risk Ratio (M-H, Fixed, 95\% Cl) & $3.0[0.13,70.83]$ \\
\hline 6.2 Vomiting & 1 & 60 & Risk Ratio (M-H, Fixed, 95\% Cl) & $0.2[0.01,4.00]$ \\
\hline 6.3 Abdominal pain & 1 & 60 & Risk Ratio (M-H, Fixed, 95\% Cl) & $0.33[0.12,0.92]$ \\
\hline
\end{tabular}

Drugs for treating urinary schistosomiasis (Review) 


\begin{tabular}{|c|c|c|c|c|}
\hline Outcome or subgroup title & $\begin{array}{l}\text { No. of } \\
\text { studies }\end{array}$ & $\begin{array}{l}\text { No. of } \\
\text { partici- } \\
\text { pants }\end{array}$ & Statistical method & Effect size \\
\hline 6.4 Headache & 1 & 60 & Risk Ratio (M-H, Fixed, 95\% Cl) & $0.33[0.01,7.87]$ \\
\hline 6.5 Fever & 1 & 60 & Risk Ratio (M-H, Fixed, 95\% Cl) & $0.33[0.01,7.87]$ \\
\hline 6.6 Loose bowel motions & 1 & 60 & Risk Ratio (M-H, Fixed, 95\% Cl) & $1.0[0.07,15.26]$ \\
\hline 6.7 Dizziness & 1 & 60 & Risk Ratio (M-H, Fixed, 95\% Cl) & $1.0[0.07,15.26]$ \\
\hline 6.8 Itching & 1 & 60 & Risk Ratio (M-H, Fixed, 95\% Cl) & $1.0[0.07,15.26]$ \\
\hline 6.9 Body pain & 1 & 60 & Risk Ratio (M-H, Fixed, 95\% Cl) & $1.0[0.07,15.26]$ \\
\hline $\begin{array}{l}7 \text { Praziquantel } 40 \mathrm{mg} / \mathrm{kg} \\
\text { once a year versus metri- } \\
\text { fonate } 10 \mathrm{mg} / \mathrm{kg} \text { every } 4 \\
\text { months }\end{array}$ & 1 & & Risk Ratio (M-H, Fixed, 95\% Cl) & Subtotals only \\
\hline $\begin{array}{l}\text { 7.1 Parasitological failure at } \\
\text { one year }\end{array}$ & 1 & 1436 & Risk Ratio (M-H, Fixed, 95\% Cl) & $1.05[1.00,1.11]$ \\
\hline 7.2 Haematuria at one year & 1 & 1400 & Risk Ratio (M-H, Fixed, 95\% Cl) & $1.08[0.85,1.36]$ \\
\hline 7.3 Proteinuria at one year & 1 & 1400 & Risk Ratio (M-H, Fixed, 95\% Cl) & $0.93[0.79,1.11]$ \\
\hline $\begin{array}{l}8 \text { Praziquantel } 40 \mathrm{mg} / \mathrm{kg} \\
\text { once a year versus metri- } \\
\text { fonate } 10 \mathrm{mg} / \mathrm{kg} \text { every } 4 \\
\text { months: parasitological fail- } \\
\text { ure }\end{array}$ & 1 & & Risk Ratio (M-H, Fixed, 95\% Cl) & Subtotals only \\
\hline 8.1 at one year & 1 & 1018 & Risk Ratio (M-H, Fixed, 95\% Cl) & $0.78[0.61,1.00]$ \\
\hline 8.2 at two years & 1 & 1025 & Risk Ratio (M-H, Fixed, 95\% Cl) & $0.77[0.53,1.11]$ \\
\hline 8.3 at three years & 1 & 827 & Risk Ratio (M-H, Fixed, 95\% Cl) & $0.62[0.42,0.93]$ \\
\hline $\begin{array}{l}9 \text { Praziquantel } 40 \mathrm{mg} / \mathrm{kg} \text { ver- } \\
\text { sus praziquantel } 10 \mathrm{mg} / \mathrm{kg} \\
\text { and metrifonate } 10 \mathrm{mg} / \mathrm{kg}\end{array}$ & 1 & 72 & Risk Ratio (M-H, Random, 95\% Cl) & $0.59[0.34,1.03]$ \\
\hline
\end{tabular}

\section{Analysis 10.1. Comparison 10 Praziquantel versus metrifonate, Outcome 1 Praziquantel $40 \mathrm{mg} / \mathrm{kg}$ single dose versus metrifonate $10 \mathrm{mg} / \mathrm{kg}$ single dose: parasitological failure.}

\begin{tabular}{|c|c|c|c|c|c|}
\hline Study or subgroup & $\begin{array}{c}\text { Praziquantel } \\
\mathrm{n} / \mathrm{N}\end{array}$ & $\begin{array}{c}\text { Metrifonate } \\
\mathrm{n} / \mathrm{N}\end{array}$ & $\begin{array}{c}\text { Risk Ratio } \\
\text { M-H, Fixed, 95\% Cl }\end{array}$ & Weight & $\begin{array}{c}\text { Risk Ratio } \\
\text { M-H, Fixed, 95\% CI }\end{array}$ \\
\hline \multicolumn{6}{|l|}{ 10.1.1 at one month } \\
\hline Pugh 1983 MWI & $34 / 93$ & $72 / 90$ & & $100 \%$ & $0.46[0.34,0.61]$ \\
\hline Subtotal $(95 \% \mathrm{Cl})$ & 93 & 90 & & $100 \%$ & $0.46[0.34,0.61]$ \\
\hline \multicolumn{6}{|c|}{ Total events: 34 (Praziquantel), 72 (Metrifonate) } \\
\hline
\end{tabular}




\begin{tabular}{|c|c|c|c|c|c|}
\hline Study or subgroup & $\begin{array}{c}\text { Praziquantel } \\
\mathrm{n} / \mathrm{N} \\
\end{array}$ & $\begin{array}{c}\text { Metrifonate } \\
\mathrm{n} / \mathrm{N} \\
\end{array}$ & $\begin{array}{c}\text { Risk Ratio } \\
\text { M-H, Fixed, 95\% Cl }\end{array}$ & Weight & $\begin{array}{c}\text { Risk Ratio } \\
\text { M-H, Fixed, 95\% Cl }\end{array}$ \\
\hline \multicolumn{6}{|c|}{ Heterogeneity: $\mathrm{Tau}^{2}=0 ; \mathrm{Chi}^{2}=0, \mathrm{df}=0(\mathrm{P}<0.0001) ;\left.\right|^{2}=100 \%$} \\
\hline \multicolumn{6}{|c|}{ 10.1.2 at two to three months } \\
\hline Wilkins 1987 GMB & $11 / 33$ & $29 / 39$ & $\longrightarrow$ & $25.4 \%$ & $0.45[0.27,0.75]$ \\
\hline Subtotal $(95 \% \mathrm{Cl})$ & 122 & 121 & & $100 \%$ & $0.67[0.57,0.79]$ \\
\hline \multicolumn{6}{|c|}{ Total events: 72 (Praziquantel), 104 (Metrifonate) } \\
\hline \multicolumn{6}{|c|}{ Heterogeneity: $\operatorname{Tau}^{2}=0 ; \mathrm{Chi}^{2}=4.22, \mathrm{df}=1(\mathrm{P}=0.04) ; \mathrm{I}^{2}=76.28 \%$} \\
\hline \multicolumn{6}{|c|}{ Test for overall effect: $Z=4.77(P<0.0001)$} \\
\hline Pugh 1983 MWI & $64 / 77$ & $67 / 72$ & & $100 \%$ & $0.89[0.79,1.01]$ \\
\hline Subtotal $(95 \% \mathrm{CI})$ & 77 & 72 & & $100 \%$ & $0.89[0.79,1.01]$ \\
\hline \multicolumn{6}{|c|}{ Total events: 64 (Praziquantel), 67 (Metrifonate) } \\
\hline \multicolumn{6}{|c|}{ Heterogeneity: Not applicable } \\
\hline \multicolumn{6}{|c|}{ Test for overall effect: $Z=1.86(P=0.06)$} \\
\hline \multicolumn{6}{|l|}{ 10.1.4 at eight months } \\
\hline Stephenson 1989 KEN & $14 / 105$ & $64 / 103$ & - & $100 \%$ & $0.21[0.13,0.36]$ \\
\hline Subtotal $(95 \% \mathrm{Cl})$ & 105 & 103 & & $100 \%$ & $0.21[0.13,0.36]$ \\
\hline \multicolumn{6}{|c|}{ Total events: 14 (Praziquantel), 64 (Metrifonate) } \\
\hline \multicolumn{6}{|c|}{ Heterogeneity: Not applicable } \\
\hline \multicolumn{6}{|c|}{ Test for overall effect: $Z=5.91(P<0.0001)$} \\
\hline \multicolumn{6}{|c|}{ Test for subgroup differences: $\mathrm{Chi}^{2}=44.36, \mathrm{df}=1(\mathrm{P}<0.0001), \mathrm{I}^{2}=93.24 \%$} \\
\hline
\end{tabular}

\section{Analysis 10.2. Comparison 10 Praziquantel versus metrifonate, Outcome 2 Praziquantel $40 \mathrm{mg} / \mathrm{kg}$ single dose versus metrifonate $10 \mathrm{mg} / \mathrm{kg}$ single dose: haemoglobin.}

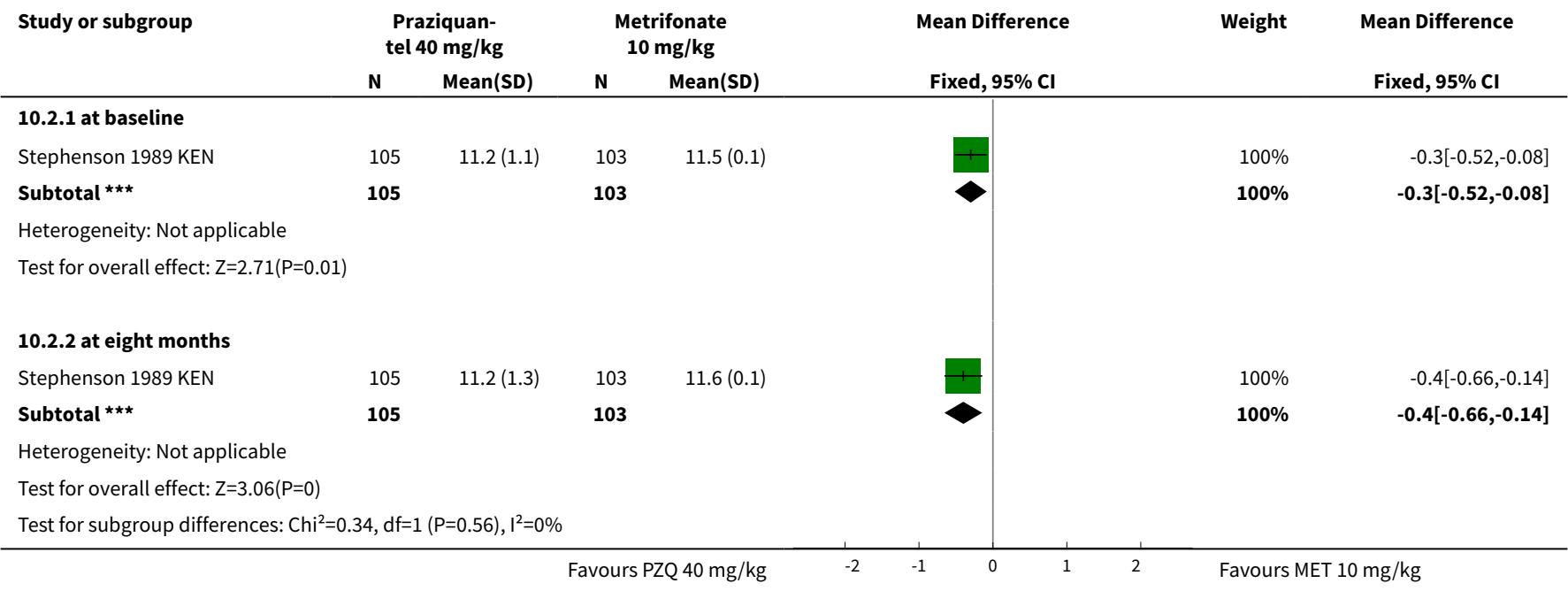

Drugs for treating urinary schistosomiasis (Review) 
Analysis 10.3. Comparison 10 Praziquantel versus metrifonate, Outcome 3 Praziquantel $40 \mathrm{mg} /$ $\mathrm{kg}$ single dose versus metrifonate 20 and $30 \mathrm{mg} / \mathrm{kg}$ given as split doses: parasitological failure.

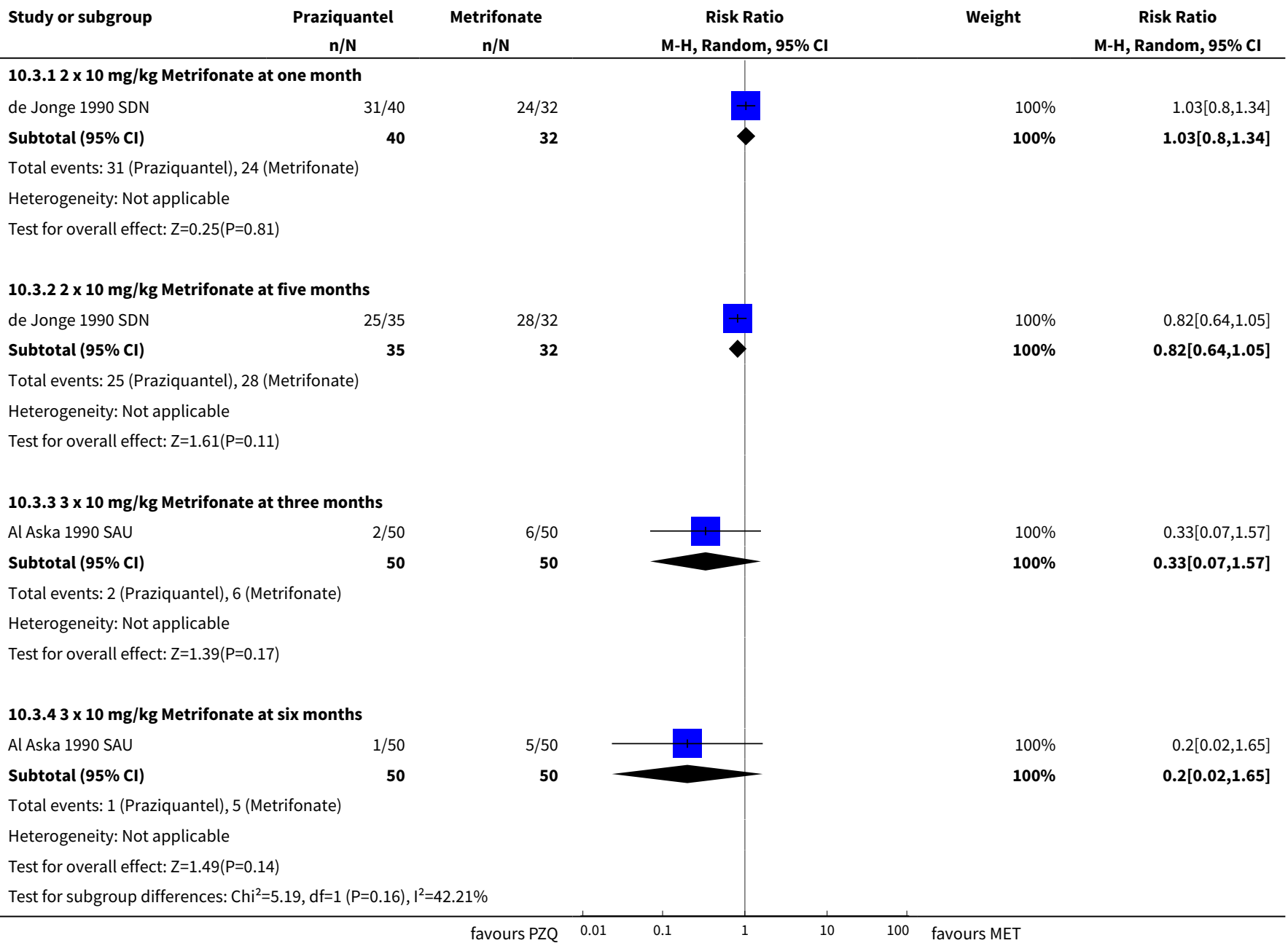

Analysis 10.4. Comparison 10 Praziquantel versus metrifonate, Outcome 4 Praziquantel $40 \mathrm{mg} / \mathrm{kg}$ single dose versus metrifonate $30 \mathrm{mg} / \mathrm{kg}$ given as split dose: adverse events.

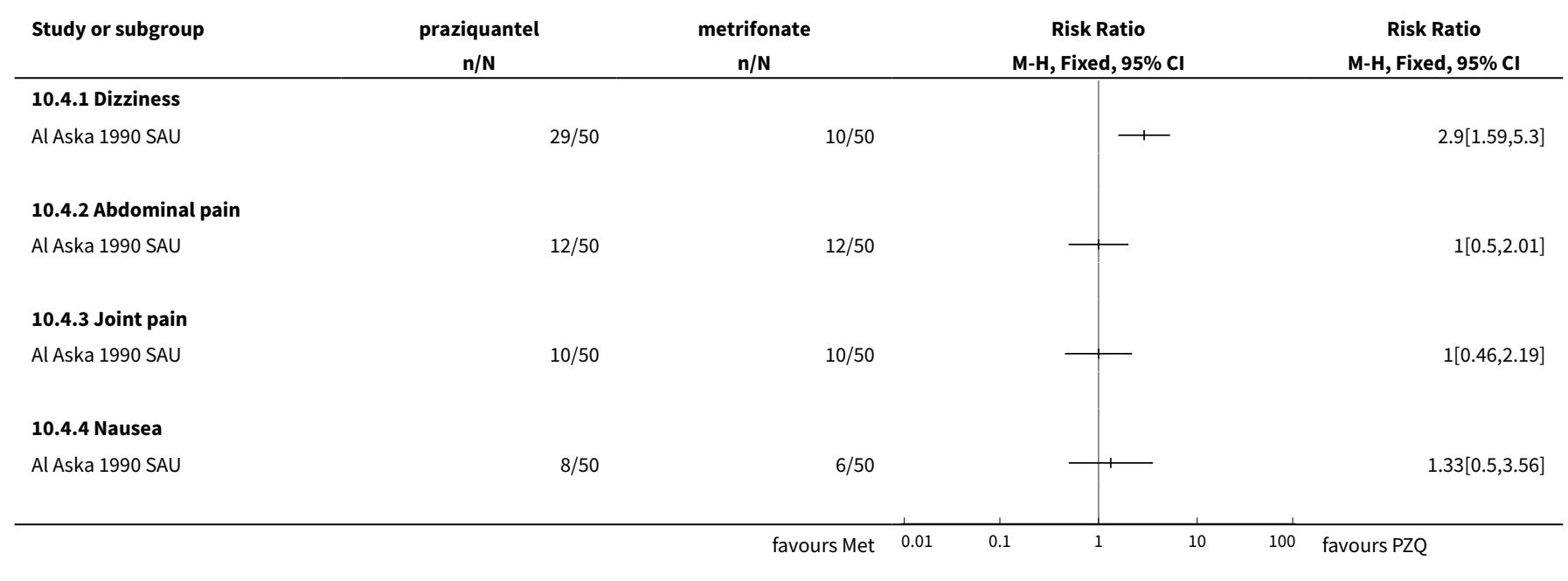

Drugs for treating urinary schistosomiasis (Review) 


\begin{tabular}{|c|c|c|c|c|}
\hline Study or subgroup & $\begin{array}{c}\text { praziquantel } \\
n / N \\
\end{array}$ & $\begin{array}{c}\text { metrifonate } \\
n / N\end{array}$ & $\begin{array}{c}\text { Risk Ratio } \\
\text { M-H, Fixed, 95\% Cl }\end{array}$ & $\begin{array}{c}\text { Risk Ratio } \\
\text { M-H, Fixed, 95\% Cl }\end{array}$ \\
\hline \multicolumn{5}{|l|}{ 10.4.5 Rash } \\
\hline Al Aska 1990 SAU & $6 / 50$ & $2 / 50$ & 千 & $3[0.64,14.16]$ \\
\hline \multicolumn{5}{|l|}{ 10.4.6 Vomiting } \\
\hline Al Aska 1990 SAU & $6 / 50$ & $8 / 50$ & +1 & $0.75[0.28,2]$ \\
\hline \multicolumn{5}{|l|}{ 10.4.7 Itching } \\
\hline Al Aska 1990 SAU & $6 / 50$ & $0 / 50$ & + & $13[0.75,224.77]$ \\
\hline \multicolumn{5}{|l|}{ 10.4.8 Fatigue } \\
\hline Al Aska 1990 SAU & $2 / 50$ & $8 / 50$ & & $0.25[0.06,1.12]$ \\
\hline \multicolumn{5}{|l|}{ 10.4.9 Hair loss } \\
\hline Al Aska 1990 SAU & $2 / 50$ & $0 / 50$ & & $5[0.25,101.58]$ \\
\hline \multicolumn{5}{|c|}{ 10.4.10 Change in taste } \\
\hline Al Aska 1990 SAU & $1 / 50$ & $2 / 50$ & - & $0.5[0.05,5.34]$ \\
\hline \multicolumn{5}{|l|}{ 10.4.11 Diarrhoea } \\
\hline Al Aska 1990 SAU & $1 / 50$ & $4 / 50$ & - & $0.25[0.03,2.16]$ \\
\hline \multicolumn{5}{|l|}{ 10.4.12 Convulsion } \\
\hline Al Aska 1990 SAU & $0 / 50$ & $0 / 50$ & & Not estimable \\
\hline
\end{tabular}

Analysis 10.5. Comparison 10 Praziquantel versus metrifonate, Outcome 5 Praziquantel 30 $\mathrm{mg} / \mathbf{k g}$ single dose versus metrifonate $30 \mathrm{mg} / \mathrm{kg}$ given as split dose: parasitological failure.

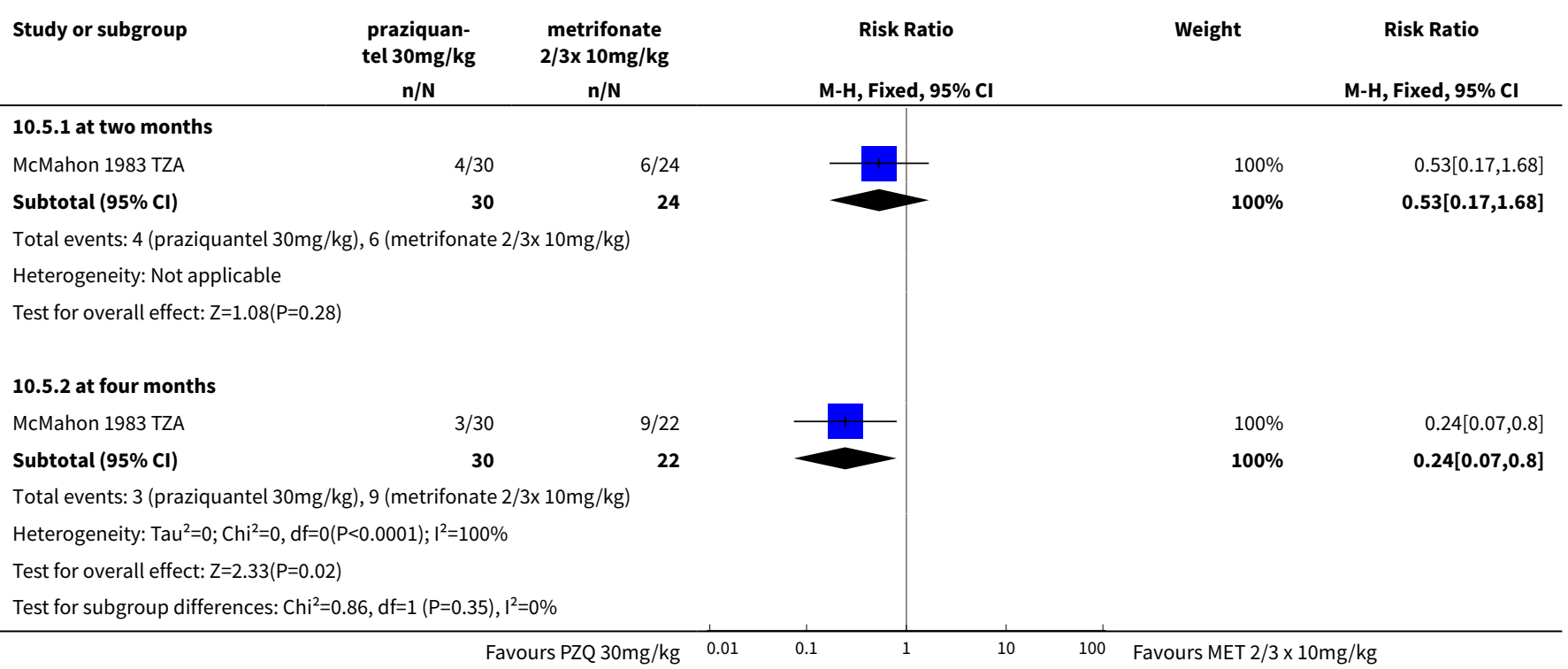


Analysis 10.6. Comparison 10 Praziquantel versus metrifonate, Outcome 6 Praziquantel $30 \mathrm{mg} / \mathrm{kg}$ single dose versus metrifonate $30 \mathrm{mg} / \mathrm{kg}$ given as split dose: adverse events.

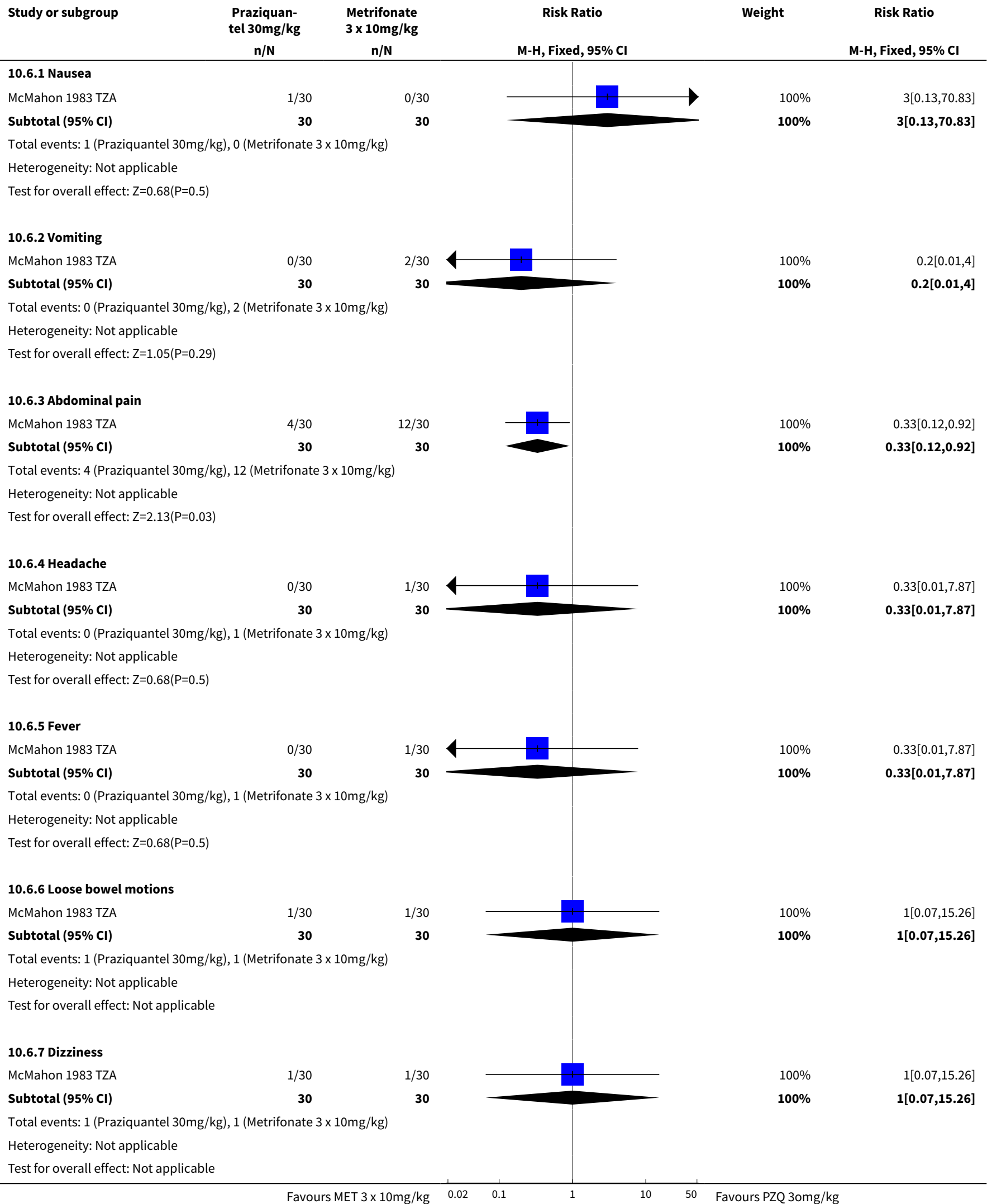

Drugs for treating urinary schistosomiasis (Review) 


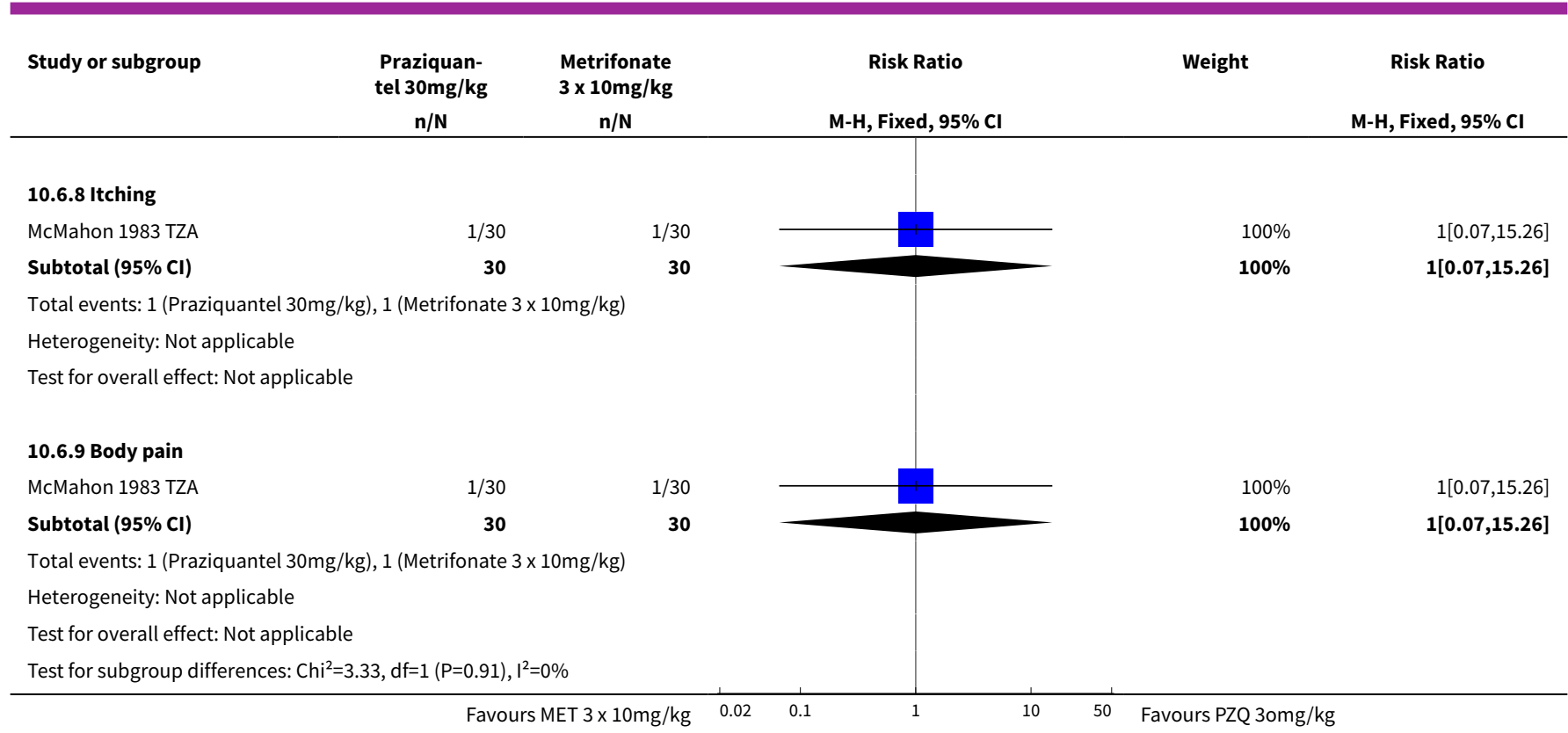

Analysis 10.7. Comparison 10 Praziquantel versus metrifonate, Outcome 7 Praziquantel $40 \mathrm{mg} / \mathrm{kg}$ once a year versus metrifonate $10 \mathrm{mg} / \mathrm{kg}$ every 4 months.

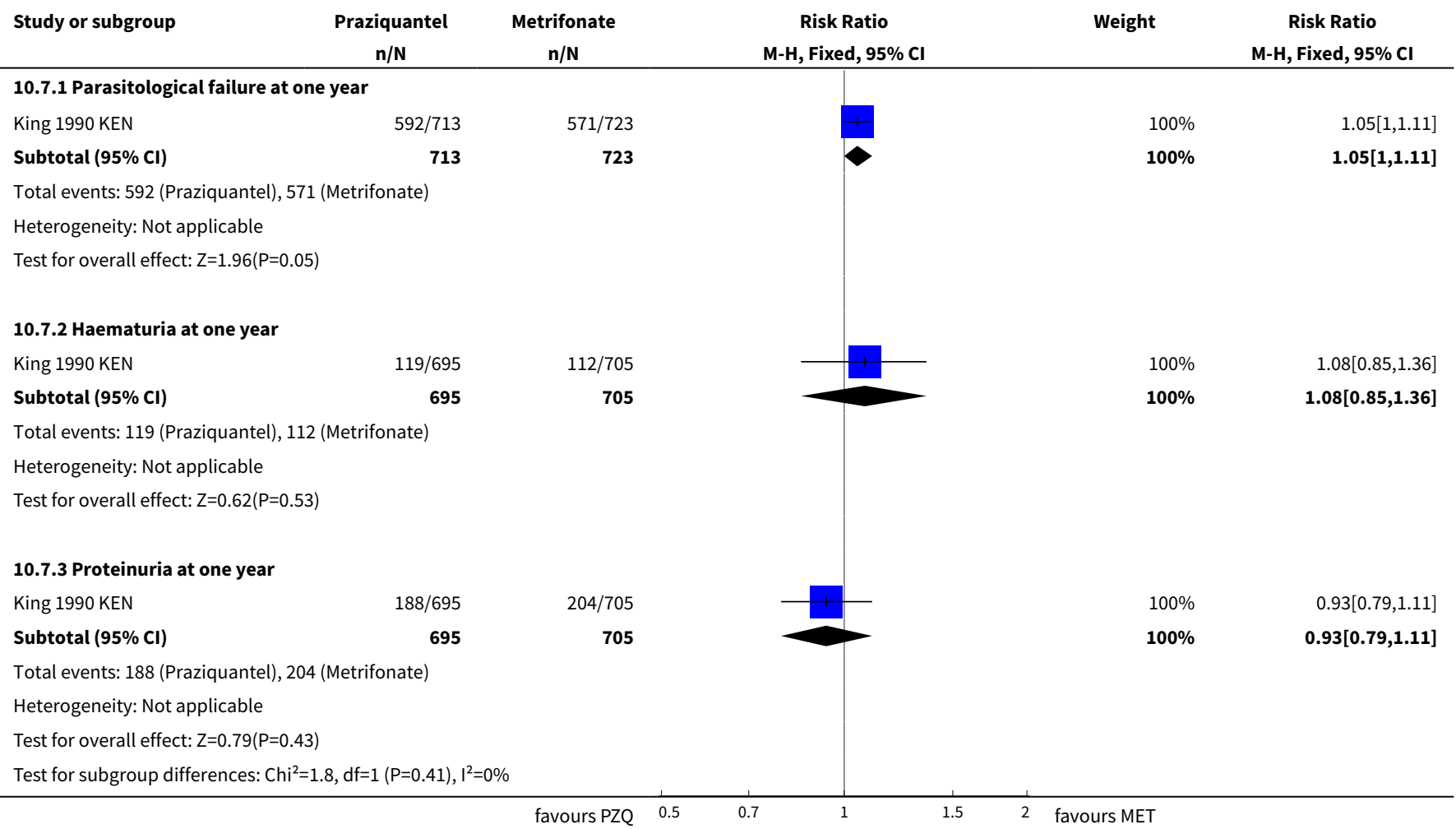


Analysis 10.8. Comparison 10 Praziquantel versus metrifonate, Outcome 8 Praziquantel $40 \mathrm{mg} / \mathrm{kg}$ once a year versus metrifonate $10 \mathrm{mg} / \mathrm{kg}$ every 4 months: parasitological failure.

\begin{tabular}{|c|c|c|c|c|c|}
\hline Study or subgroup & $\begin{array}{c}\text { Praziquantel } \\
n / N\end{array}$ & $\begin{array}{c}\text { Metrifonate } \\
n / N\end{array}$ & $\begin{array}{c}\text { Risk Ratio } \\
\text { M-H, Fixed, 95\% Cl }\end{array}$ & Weight & $\begin{array}{c}\text { Risk Ratio } \\
\text { M-H, Fixed, 95\% Cl }\end{array}$ \\
\hline \multicolumn{6}{|l|}{ 10.8.1 at one year } \\
\hline King 1990 KEN & $89 / 483$ & $126 / 535$ & & $100 \%$ & $0.78[0.61,1]$ \\
\hline Subtotal $(95 \% \mathrm{CI})$ & 483 & 535 & & $100 \%$ & $0.78[0.61,1]$ \\
\hline \multicolumn{6}{|c|}{ Total events: 89 (Praziquantel), 126 (Metrifonate) } \\
\hline \multicolumn{6}{|c|}{ Heterogeneity: Not applicable } \\
\hline \multicolumn{6}{|l|}{ 10.8.2 at two years } \\
\hline King 1990 KEN & $42 / 481$ & $62 / 544$ & - & $100 \%$ & $0.77[0.53,1.11]$ \\
\hline Subtotal $(95 \% \mathrm{Cl})$ & 481 & 544 & & $100 \%$ & $0.77[0.53,1.11]$ \\
\hline \multicolumn{6}{|c|}{ Total events: 42 (Praziquantel), 62 (Metrifonate) } \\
\hline \multicolumn{6}{|c|}{ Heterogeneity: Not applicable } \\
\hline \multicolumn{6}{|l|}{ 10.8.3 at three years } \\
\hline King 1990 KEN & $34 / 402$ & $58 / 425$ & & $100 \%$ & $0.62[0.42,0.93]$ \\
\hline Subtotal $(95 \% \mathrm{CI})$ & 402 & 425 & & $100 \%$ & $0.62[0.42,0.93]$ \\
\hline \multicolumn{6}{|c|}{ Total events: 34 (Praziquantel), 58 (Metrifonate) } \\
\hline \multicolumn{6}{|c|}{ Heterogeneity: Not applicable } \\
\hline \multicolumn{6}{|c|}{ Test for overall effect: $Z=2.34(P=0.02)$} \\
\hline Test for subgroup dif & 99, df $=1(P=0.61)$, & & & & \\
\hline
\end{tabular}

Analysis 10.9. Comparison 10 Praziquantel versus metrifonate, Outcome 9 Praziquantel $40 \mathrm{mg} / \mathrm{kg}$ versus praziquantel $10 \mathrm{mg} / \mathrm{kg}$ and metrifonate $10 \mathrm{mg} / \mathrm{kg}$.

\begin{tabular}{|c|c|c|c|c|c|}
\hline \multirow[t]{2}{*}{ Study or subgroup } & Praziquantel & $\begin{array}{l}\text { Praziquantel } \\
+ \text { Metrifonat }\end{array}$ & Risk Ratio & Weight & Risk Ratio \\
\hline & $n / N$ & $n / N$ & M-H, Random, 95\% Cl & & M-H, Random, 95\% Cl \\
\hline Wilkins 1987 GMB & $11 / 33$ & $22 / 39$ & & $100 \%$ & $0.59[0.34,1.03]$ \\
\hline Total $(95 \% \mathrm{Cl})$ & 33 & 39 & & $100 \%$ & $0.59[0.34,1.03]$ \\
\hline \multicolumn{6}{|c|}{ Total events: 11 (Praziquantel), 22 (Praziquantel + Metrifonat) } \\
\hline \multicolumn{6}{|c|}{ Test for overall effect: $\mathrm{Z}=1.86(\mathrm{P}=0.06)$} \\
\hline
\end{tabular}

\section{Comparison 11. Artesunate versus placebo}

\begin{tabular}{lllll}
\hline Outcome or subgroup title & $\begin{array}{l}\text { No. of } \\
\text { studies }\end{array}$ & $\begin{array}{l}\text { No. of } \\
\text { partici- } \\
\text { pants }\end{array}$ & Statistical method & Effect size \\
\hline $\begin{array}{l}1 \text { Parasitological failure at } \\
\text { eight weeks }\end{array}$ & 2 & 251 & Risk Ratio (M-H, Random, 95\% Cl) & $0.53[0.16,1.71]$ \\
\hline
\end{tabular}




\begin{tabular}{|c|c|c|c|c|}
\hline Outcome or subgroup title & $\begin{array}{l}\text { No. of } \\
\text { studies }\end{array}$ & $\begin{array}{l}\text { No. of } \\
\text { partici- } \\
\text { pants }\end{array}$ & Statistical method & Effect size \\
\hline 2 Haematuria & 1 & 119 & Risk Ratio (M-H, Fixed, 95\% Cl) & $1.22[0.85,1.76]$ \\
\hline 3 Adverse events & 1 & & Risk Ratio (M-H, Fixed, 95\% CI) & Totals not selected \\
\hline 3.1 Headache & 1 & & Risk Ratio (M-H, Fixed, 95\% CI) & $0.0[0.0,0.0]$ \\
\hline 3.2 Vomiting & 1 & & Risk Ratio (M-H, Fixed, 95\% CI) & $0.0[0.0,0.0]$ \\
\hline 3.3 Fever & 1 & & Risk Ratio (M-H, Fixed, 95\% Cl) & $0.0[0.0,0.0]$ \\
\hline 3.4 Itching & 1 & & Risk Ratio (M-H, Fixed, 95\% CI) & $0.0[0.0,0.0]$ \\
\hline 3.5 Cough & 1 & & Risk Ratio (M-H, Fixed, 95\% CI) & $0.0[0.0,0.0]$ \\
\hline 3.6 Diarrhoea & 1 & & Risk Ratio (M-H, Fixed, 95\% Cl) & $0.0[0.0,0.0]$ \\
\hline 3.7 Chills & 1 & & Risk Ratio (M-H, Fixed, 95\% Cl) & $0.0[0.0,0.0]$ \\
\hline 3.8 Nausea & 1 & & Risk Ratio (M-H, Fixed, 95\% Cl) & $0.0[0.0,0.0]$ \\
\hline 3.9 Dizziness & 1 & & Risk Ratio (M-H, Fixed, 95\% CI) & $0.0[0.0,0.0]$ \\
\hline 3.10 Abdominal pain & 1 & & Risk Ratio (M-H, Fixed, 95\% Cl) & $0.0[0.0,0.0]$ \\
\hline 3.11 Constipation & 1 & & Risk Ratio (M-H, Fixed, 95\% Cl) & $0.0[0.0,0.0]$ \\
\hline
\end{tabular}

Analysis 11.1. Comparison 11 Artesunate versus placebo, Outcome 1 Parasitological failure at eight weeks.

\begin{tabular}{|c|c|c|c|c|c|}
\hline Study or subgroup & $\begin{array}{l}\text { ART } 4 \mathrm{mg} / \\
\mathrm{kg} / \mathrm{d} \text { for } 3 \mathrm{~d} \\
\mathrm{n} / \mathrm{N}\end{array}$ & $\begin{array}{c}\text { Placebo } \\
\text { n/N }\end{array}$ & $\begin{array}{c}\text { Risk Ratio } \\
\text { M-H, Random, } 95 \% \mathrm{Cl}\end{array}$ & Weight & $\begin{array}{c}\text { Risk Ratio } \\
\text { M-H, Random, } 95 \% \mathrm{Cl}\end{array}$ \\
\hline Borrmann 2001 GAB & $65 / 89$ & $24 / 30$ & & $50.69 \%$ & $0.91[0.73,1.14]$ \\
\hline Inyang Etoh 2009 NGA & $24 / 88$ & $40 / 44$ & 冓 & $49.31 \%$ & $0.3[0.21,0.43]$ \\
\hline Total $(95 \% \mathrm{Cl})$ & 177 & 74 & & $100 \%$ & $0.53[0.16,1.71]$ \\
\hline \multicolumn{6}{|c|}{ Total events: 89 (ART 4mg/kg/d for 3d), 64 (Placebo) } \\
\hline \multicolumn{6}{|c|}{ Heterogeneity: $\mathrm{Tau}^{2}=0.7 ; \mathrm{Chi}^{2}=32.13, \mathrm{df}=1(\mathrm{P}<0.0001) ; \mathrm{I}^{2}=96.89 \%$} \\
\hline Test for overall effect: $Z$ & & & & & \\
\hline
\end{tabular}

Analysis 11.2. Comparison 11 Artesunate versus placebo, Outcome 2 Haematuria.

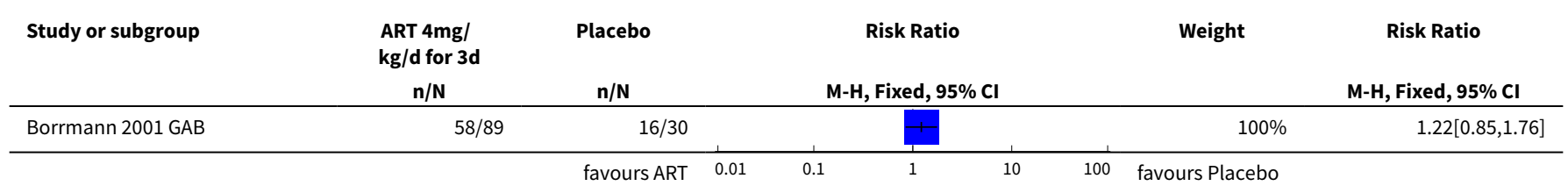




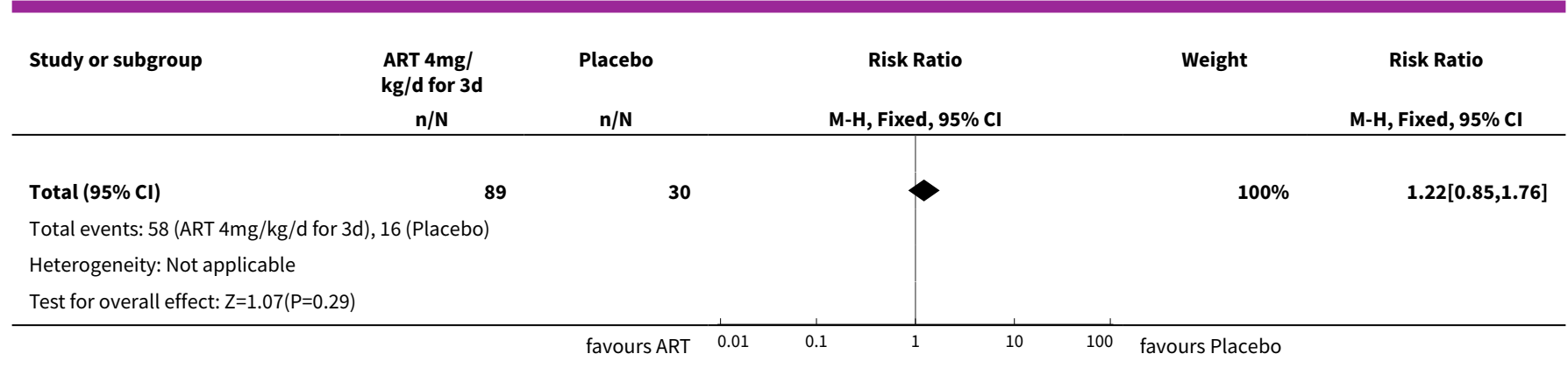

Analysis 11.3. Comparison 11 Artesunate versus placebo, Outcome 3 Adverse events.

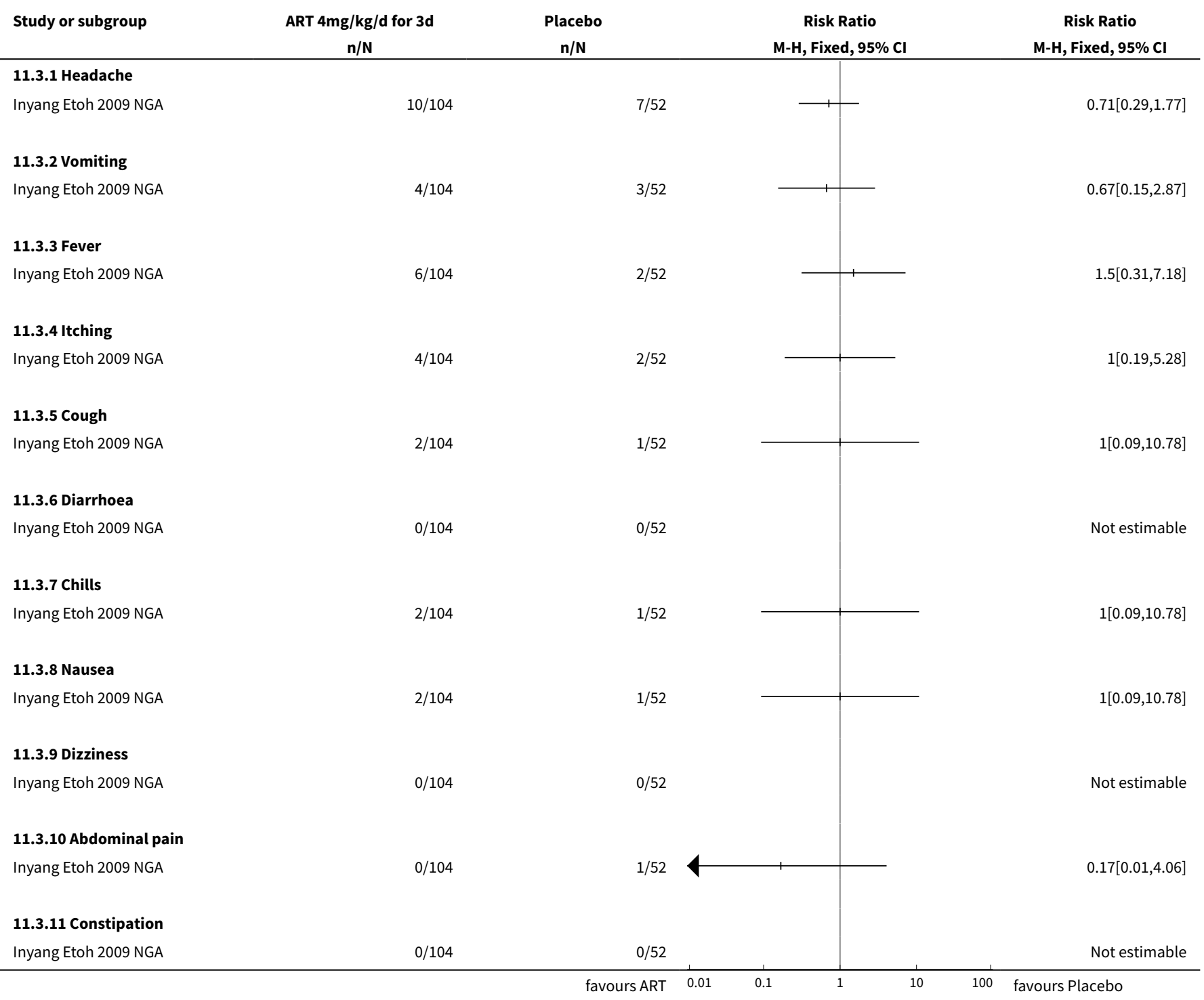

Drugs for treating urinary schistosomiasis (Review) 
Comparison 12. Praziquantel versus artesunate

\begin{tabular}{|c|c|c|c|c|}
\hline $\begin{array}{l}\text { Outcome or subgroup ti- } \\
\text { tle }\end{array}$ & $\begin{array}{l}\text { No. of } \\
\text { studies }\end{array}$ & $\begin{array}{l}\text { No. of } \\
\text { partici- } \\
\text { pants }\end{array}$ & Statistical method & Effect size \\
\hline 1 Parasitological failure & 3 & & Risk Ratio (M-H, Random, 95\% Cl) & Subtotals only \\
\hline 1.1 at day 28 & 1 & 46 & Risk Ratio (M-H, Random, 95\% Cl) & $0.15[0.05,0.46]$ \\
\hline 1.2 at day 56 & 2 & 352 & Risk Ratio (M-H, Random, 95\% Cl) & $0.58[0.23,1.44]$ \\
\hline 2 Haematuria & 1 & 178 & Risk Ratio (M-H, Random, 95\% Cl) & $0.43[0.30,0.62]$ \\
\hline 3 Adverse events & 1 & & Risk Ratio (M-H, Fixed, 95\% Cl) & Subtotals only \\
\hline 3.1 Abdominal pain & 1 & 208 & Risk Ratio (M-H, Fixed, 95\% Cl) & $0.0[0.0,0.0]$ \\
\hline 3.2 Dizziness & 1 & 208 & Risk Ratio (M-H, Fixed, 95\% Cl) & $0.0[0.0,0.0]$ \\
\hline 3.3 Headache & 1 & 208 & Risk Ratio (M-H, Fixed, 95\% Cl) & $1.0[0.43,2.30]$ \\
\hline 3.4 Vomiting & 1 & 208 & Risk Ratio (M-H, Fixed, 95\% Cl) & $1.0[0.26,3.89]$ \\
\hline 3.5 Fever & 1 & 208 & Risk Ratio (M-H, Fixed, 95\% Cl) & $1.17[0.41,3.35]$ \\
\hline 3.6 Itching & 1 & 208 & Risk Ratio (M-H, Fixed, 95\% Cl) & $1.0[0.26,3.89]$ \\
\hline 3.7 Cough & 1 & 208 & Risk Ratio (M-H, Fixed, 95\% Cl) & $1.0[0.14,6.97]$ \\
\hline 3.8 Diarrhoea & 1 & 208 & Risk Ratio (M-H, Fixed, 95\% Cl) & $0.0[0.0,0.0]$ \\
\hline 3.9 Chills & 1 & 208 & Risk Ratio (M-H, Fixed, 95\% Cl) & $1.5[0.26,8.79]$ \\
\hline 3.10 Nausea & 1 & 208 & Risk Ratio (M-H, Fixed, 95\% Cl) & $1.0[0.14,6.97]$ \\
\hline 3.11 Constipation & 1 & 208 & Risk Ratio (M-H, Fixed, 95\% Cl) & $3.0[0.12,72.80]$ \\
\hline
\end{tabular}

Analysis 12.1. Comparison 12 Praziquantel versus artesunate, Outcome 1 Parasitological failure.

\begin{tabular}{|c|c|c|c|c|c|}
\hline \multirow[t]{2}{*}{ Study or subgroup } & \multirow{2}{*}{$\begin{array}{c}\text { PZQ 40mg/kg } \\
\text { n/N }\end{array}$} & \multirow{2}{*}{$\begin{array}{l}\text { ART } 4 \mathrm{mg} / \\
\mathrm{kg} / \mathrm{d} \text { for } 3 \mathrm{~d} \\
\mathrm{n} / \mathrm{N}\end{array}$} & Risk Ratio & \multirow[t]{2}{*}{ Weight } & \multirow{2}{*}{$\begin{array}{c}\text { Risk Ratio } \\
\text { M-H, Random, } 95 \% \mathrm{CI}\end{array}$} \\
\hline & & & M-H, Random, 95\% Cl & & \\
\hline \multicolumn{6}{|l|}{ 12.1.1 at day 28} \\
\hline Keiser 2010 CIV & $3 / 26$ & $15 / 20$ & +1 & $100 \%$ & $0.15[0.05,0.46]$ \\
\hline Subtotal $(95 \% \mathrm{Cl})$ & 26 & 20 & & $100 \%$ & $0.15[0.05,0.46]$ \\
\hline \multicolumn{6}{|c|}{ Total events: 3 (PZQ 40mg/kg), 15 (ART 4mg/kg/d for 3d) } \\
\hline \multicolumn{6}{|c|}{ Test for overall effect: $Z=3.35(P=0)$} \\
\hline \multicolumn{6}{|l|}{ 12.1.2 at day 56} \\
\hline Borrmann 2001 GAB & $24 / 89$ & $65 / 89$ & & $51.59 \%$ & $0.37[0.26,0.53]$ \\
\hline Inyang Etoh 2009 NGA & $23 / 88$ & $24 / 86$ & $\vdash$ & $48.41 \%$ & $0.94[0.57,1.53]$ \\
\hline
\end{tabular}




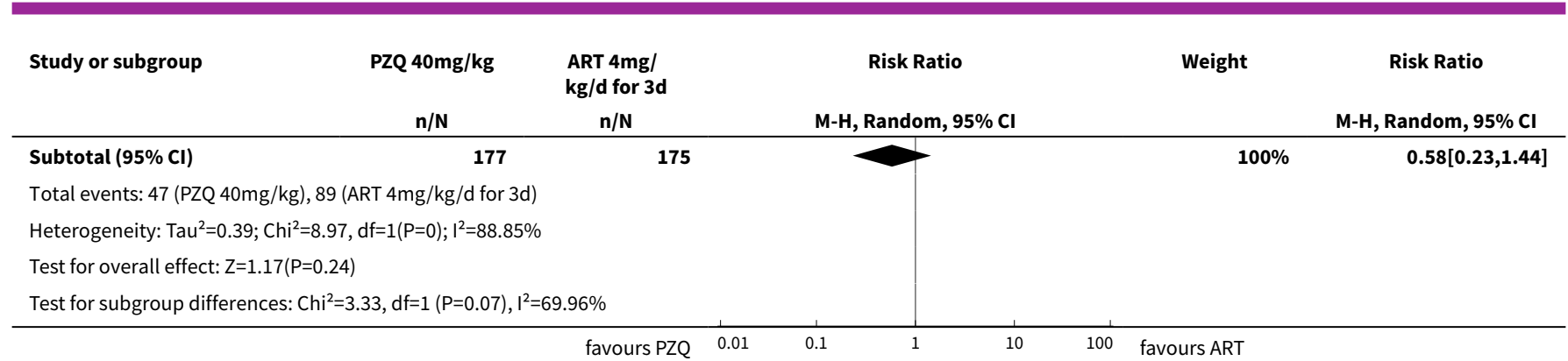

\section{Analysis 12.2. Comparison 12 Praziquantel versus artesunate, Outcome 2 Haematuria.}

\begin{tabular}{|c|c|c|c|c|c|}
\hline \multirow[t]{2}{*}{ Study or subgroup } & \multirow{2}{*}{$\begin{array}{c}\text { PZQ 40mg/kg } \\
\text { n/N } \\
\end{array}$} & \multirow{2}{*}{$\begin{array}{l}\text { ART } 4 \mathrm{mg} / \\
\mathrm{kg} / \mathrm{d} \text { for } 3 \mathrm{~d} \\
\mathrm{n} / \mathrm{N}\end{array}$} & Risk Ratio & \multirow[t]{2}{*}{ Weight } & \multirow{2}{*}{$\begin{array}{c}\text { Risk Ratio } \\
\text { M-H, Random, } 95 \% \mathrm{CI}\end{array}$} \\
\hline & & & M-H, Random, 95\% Cl & & \\
\hline Borrmann $2001 \mathrm{GAB}$ & $25 / 89$ & $58 / 89$ & - & $100 \%$ & $0.43[0.3,0.62]$ \\
\hline Total $(95 \% \mathrm{Cl})$ & 89 & 89 & & $100 \%$ & $0.43[0.3,0.62]$ \\
\hline \multicolumn{6}{|c|}{ Total events: 25 (PZQ 40mg/kg), 58 (ART 4mg/kg/d for 3d) } \\
\hline \multicolumn{6}{|c|}{ Test for overall effect: $Z=4.51(P<0.0001)$} \\
\hline
\end{tabular}

\section{Analysis 12.3. Comparison 12 Praziquantel versus artesunate, Outcome 3 Adverse events.}

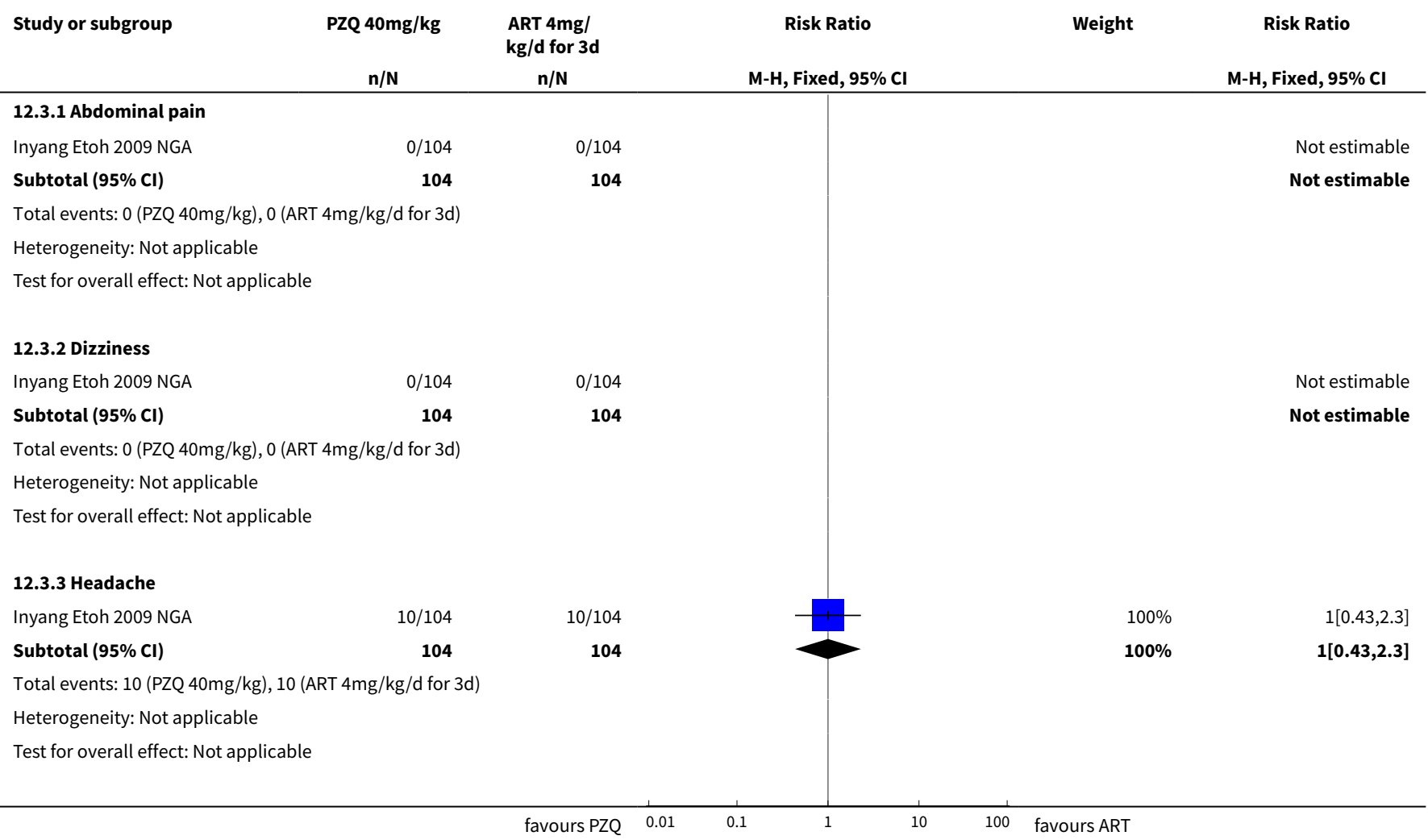




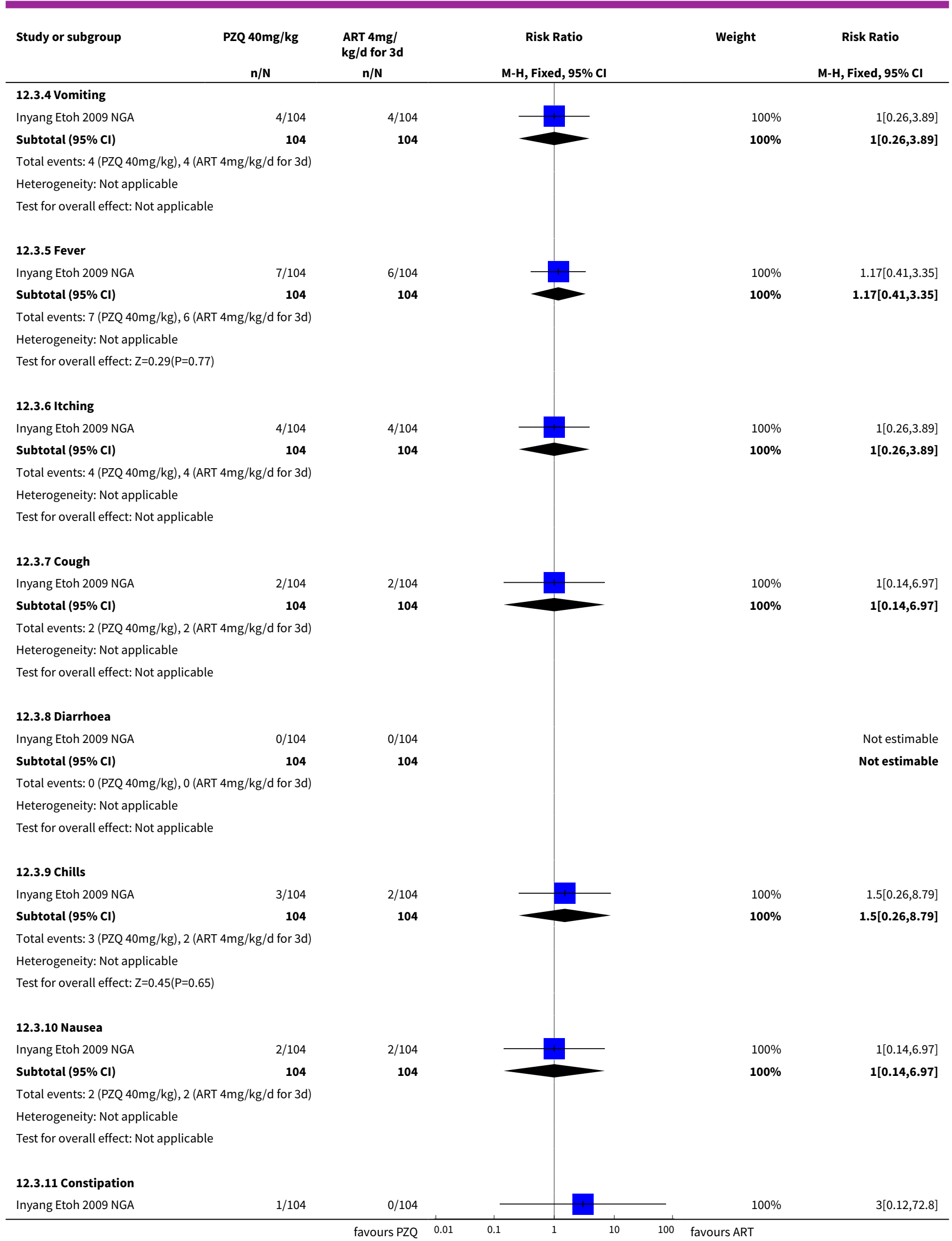

Drugs for treating urinary schistosomiasis (Review) 


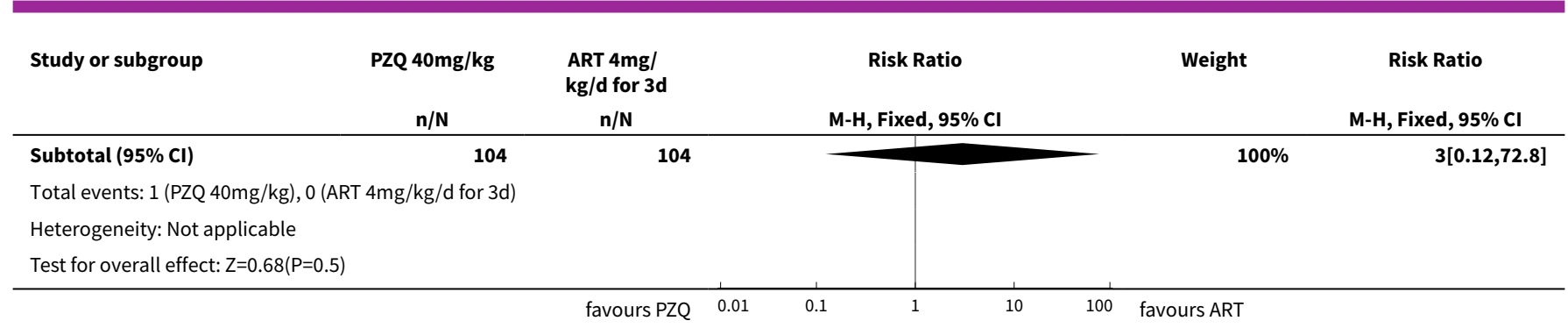

\section{Comparison 13. Praziquantel and artesunate versus praziquantel}

\begin{tabular}{|c|c|c|c|c|}
\hline Outcome or subgroup title & $\begin{array}{l}\text { No. of } \\
\text { studies }\end{array}$ & $\begin{array}{l}\text { No. of } \\
\text { partici- } \\
\text { pants }\end{array}$ & Statistical method & Effect size \\
\hline $\begin{array}{l}1 \text { Parasitological failure at } \\
\text { eight weeks }\end{array}$ & 2 & 265 & Risk Ratio (M-H, Fixed, 95\% Cl) & $0.62[0.38,0.99]$ \\
\hline 2 Haematuria at eight weeks & 1 & 177 & Risk Ratio (M-H, Fixed, 95\% Cl) & $0.69[0.40,1.18]$ \\
\hline 3 Adverse events & 1 & & Risk Ratio (M-H, Fixed, 95\% Cl) & Totals not selected \\
\hline 3.1 Abdominal pain & 1 & & Risk Ratio (M-H, Fixed, 95\% Cl) & $0.0[0.0,0.0]$ \\
\hline 3.2 Dizziness & 1 & & Risk Ratio (M-H, Fixed, 95\% Cl) & $0.0[0.0,0.0]$ \\
\hline 3.3 Headache & 1 & & Risk Ratio (M-H, Fixed, 95\% Cl) & $0.0[0.0,0.0]$ \\
\hline 3.4 Vomiting & 1 & & Risk Ratio (M-H, Fixed, 95\% Cl) & $0.0[0.0,0.0]$ \\
\hline 3.5 Fever & 1 & & Risk Ratio (M-H, Fixed, 95\% Cl) & $0.0[0.0,0.0]$ \\
\hline 3.6 Itching & 1 & & Risk Ratio (M-H, Fixed, 95\% Cl) & $0.0[0.0,0.0]$ \\
\hline 3.7 Cough & 1 & & Risk Ratio (M-H, Fixed, 95\% Cl) & $0.0[0.0,0.0]$ \\
\hline 3.8 Diarrhoea & 1 & & Risk Ratio (M-H, Fixed, 95\% Cl) & $0.0[0.0,0.0]$ \\
\hline 3.9 Chills & 1 & & Risk Ratio (M-H, Fixed, 95\% Cl) & $0.0[0.0,0.0]$ \\
\hline 3.10 Nausea & 1 & & Risk Ratio (M-H, Fixed, 95\% Cl) & $0.0[0.0,0.0]$ \\
\hline 3.11 Constipation & 1 & & Risk Ratio (M-H, Fixed, 95\% Cl) & $0.0[0.0,0.0]$ \\
\hline
\end{tabular}

\section{Analysis 13.1. Comparison 13 Praziquantel and artesunate versus praziquantel, Outcome 1 Parasitological failure at eight weeks.}

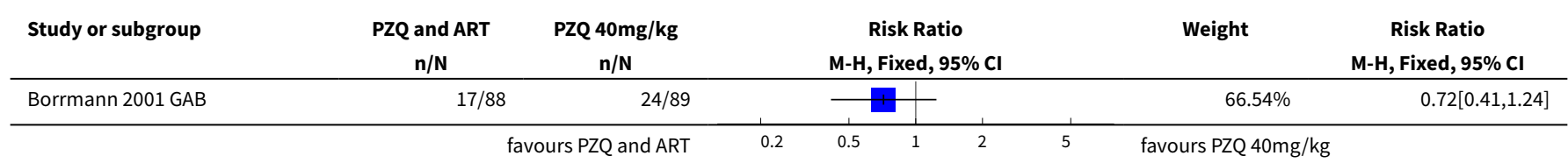




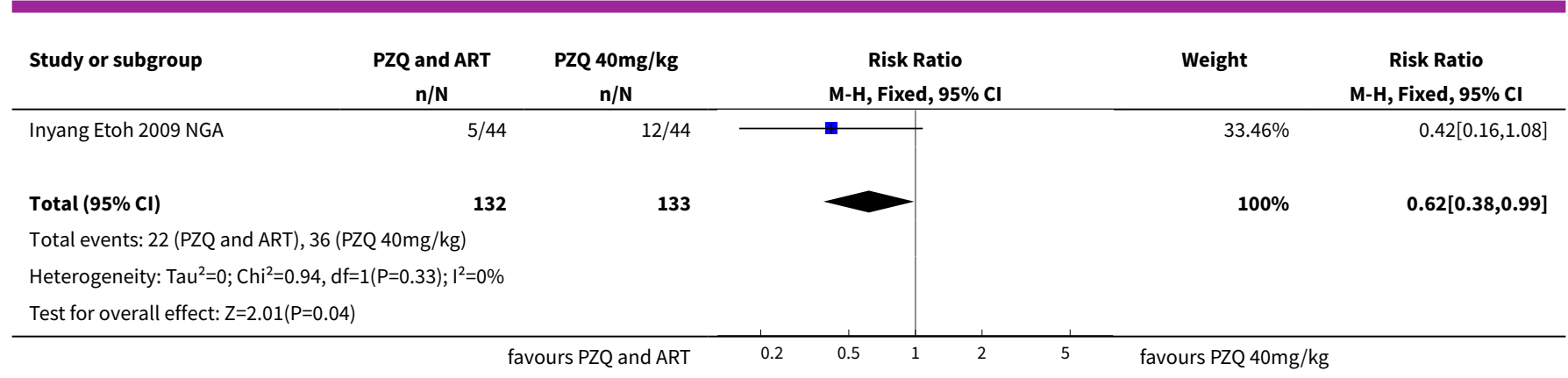

Analysis 13.2. Comparison 13 Praziquantel and artesunate versus praziquantel, Outcome 2 Haematuria at eight weeks.

\begin{tabular}{|c|c|c|c|c|c|}
\hline Study or subgroup & $\begin{array}{c}\text { PZQ and ART } \\
n / N\end{array}$ & $\begin{array}{c}\text { PZQ } 40 \mathrm{mg} / \mathrm{kg} \\
\mathrm{n} / \mathrm{N}\end{array}$ & $\begin{array}{c}\text { Risk Ratio } \\
\text { M-H, Fixed, 95\% Cl }\end{array}$ & Weight & $\begin{array}{c}\text { Risk Ratio } \\
\text { M-H, Fixed, } 95 \% \mathrm{CI}\end{array}$ \\
\hline Borrmann $2001 \mathrm{GAB}$ & $17 / 88$ & $25 / 89$ & & $100 \%$ & $0.69[0.4,1.18]$ \\
\hline Total $(95 \% \mathrm{Cl})$ & 88 & 89 & & $100 \%$ & $0.69[0.4,1.18]$ \\
\hline \multicolumn{6}{|c|}{ Total events: 17 (PZQ and ART), 25 (PZQ 40 mg/kg) } \\
\hline \multicolumn{6}{|c|}{ Heterogeneity: Not applicable } \\
\hline \multicolumn{6}{|c|}{ Test for overall effect: $Z=1.36(P=0.18)$} \\
\hline
\end{tabular}

Analysis 13.3. Comparison 13 Praziquantel and artesunate versus praziquantel, Outcome 3 Adverse events.

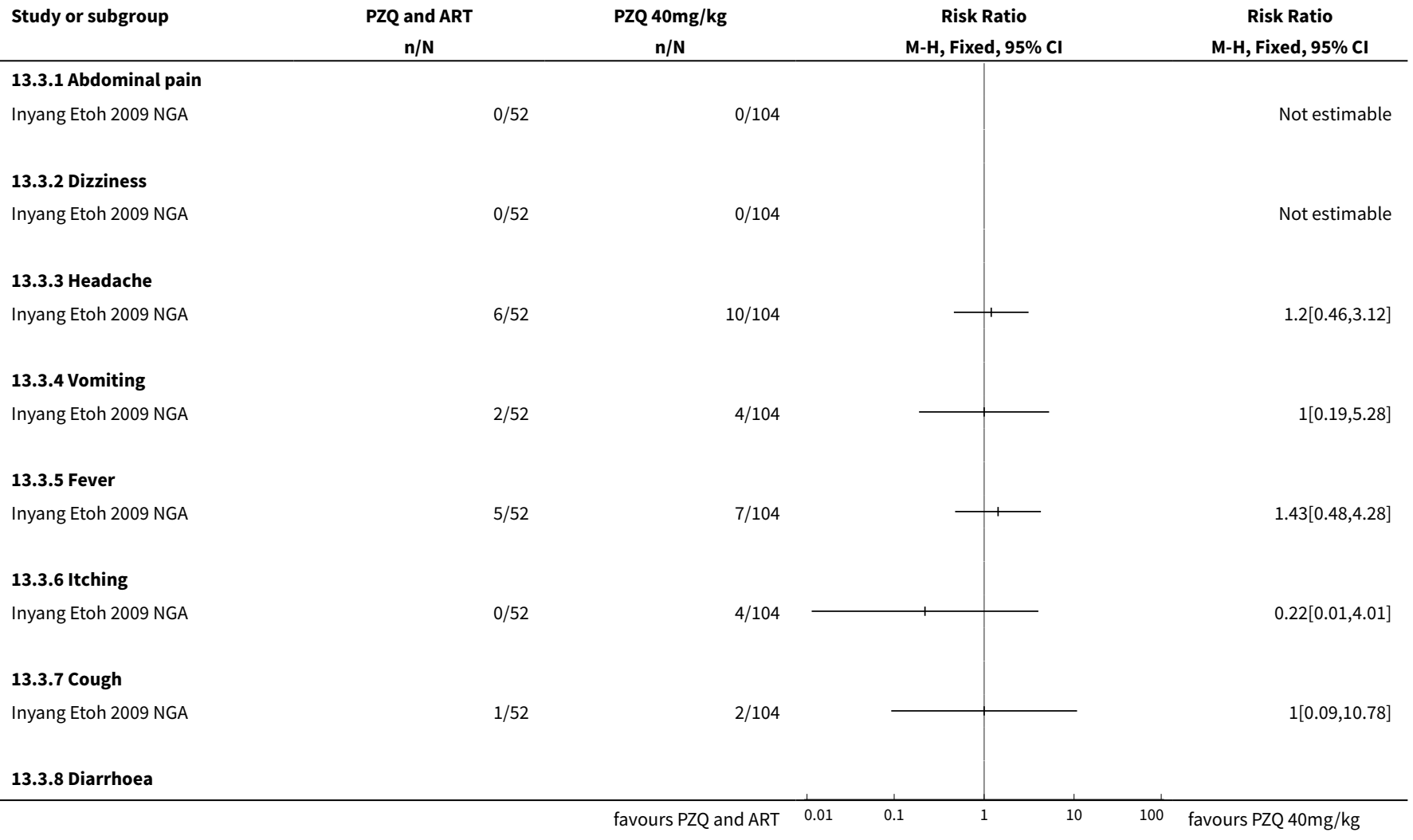




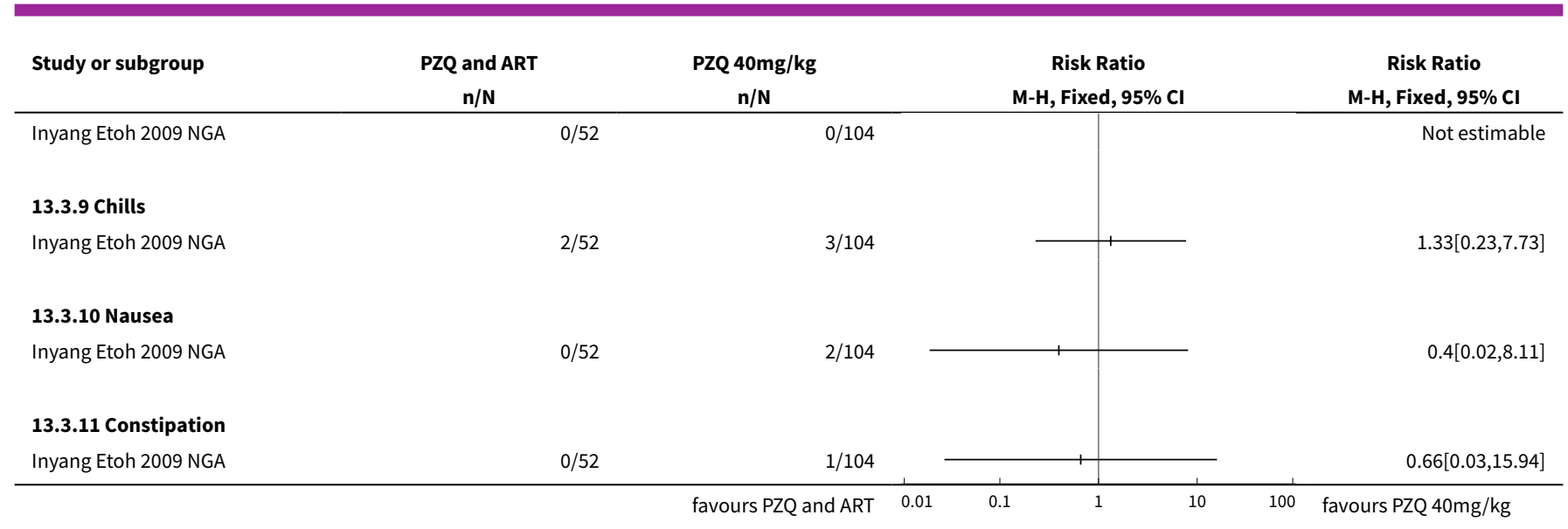

Comparison 14. Mefloquine versus placebo

\begin{tabular}{lllll}
\hline Outcome or subgroup title & $\begin{array}{l}\text { No. of } \\
\text { studies }\end{array}$ & $\begin{array}{l}\text { No. of par- } \\
\text { ticipants }\end{array}$ & Statistical method & Effect size \\
\hline 1 Parasitological failure at six weeks & 1 & 44 & Risk Ratio (M-H, Fixed, 95\% Cl) & $0.57[0.40,0.83]$ \\
\hline
\end{tabular}

Analysis 14.1. Comparison 14 Mefloquine versus placebo, Outcome 1 Parasitological failure at six weeks.

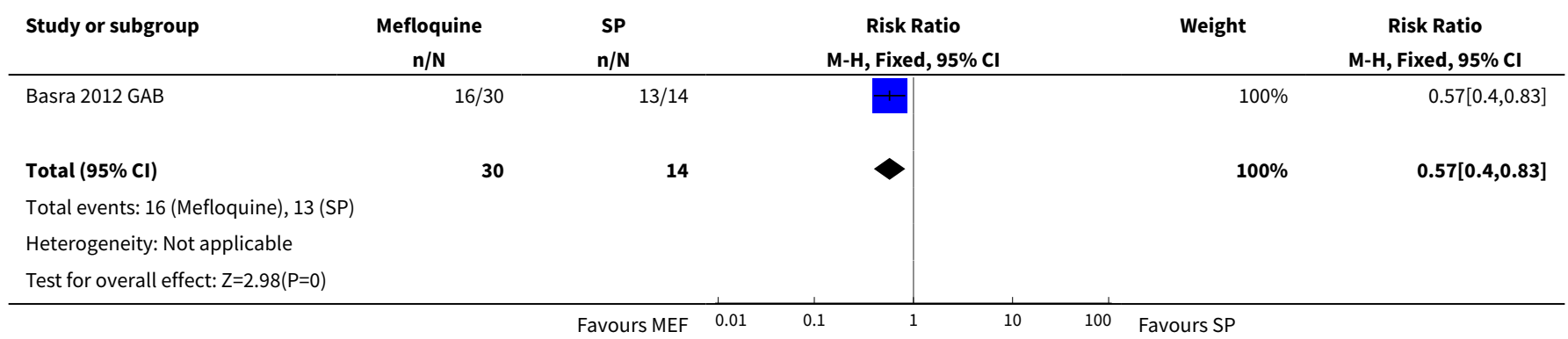

\section{Comparison 15. Praziquantel versus mefloquine}

\begin{tabular}{lllll}
\hline Outcome or subgroup title & $\begin{array}{l}\text { No. of } \\
\text { studies }\end{array}$ & $\begin{array}{l}\text { No. of par- } \\
\text { ticipants }\end{array}$ & Statistical method & Effect size \\
\hline 1 Parasitological failure at one month & 1 & 45 & Risk Ratio (M-H, Fixed, 95\% Cl) & $0.15[0.05,0.43]$ \\
\hline
\end{tabular}


Analysis 15.1. Comparison 15 Praziquantel versus mefloquine, Outcome 1 Parasitological failure at one month.

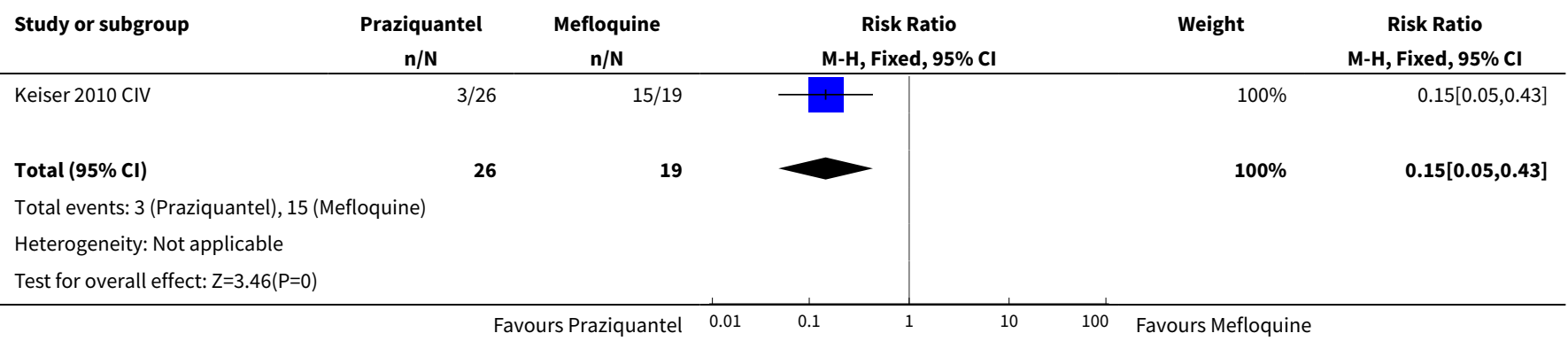

Comparison 16. Praziquantel versus artesunate and mefloquine

\begin{tabular}{llllll}
\hline Outcome or subgroup title & $\begin{array}{l}\text { No. of } \\
\text { studies }\end{array}$ & $\begin{array}{l}\text { No. of par- } \\
\text { ticipants }\end{array}$ & Statistical method & Effect size \\
\hline 1 Parasitological failure at one month & 1 & 44 & Risk Ratio (M-H, Fixed, 95\% Cl) & $0.23[0.07,0.74]$ \\
\hline
\end{tabular}

Analysis 16.1. Comparison 16 Praziquantel versus artesunate and mefloquine, Outcome 1 Parasitological failure at one month.

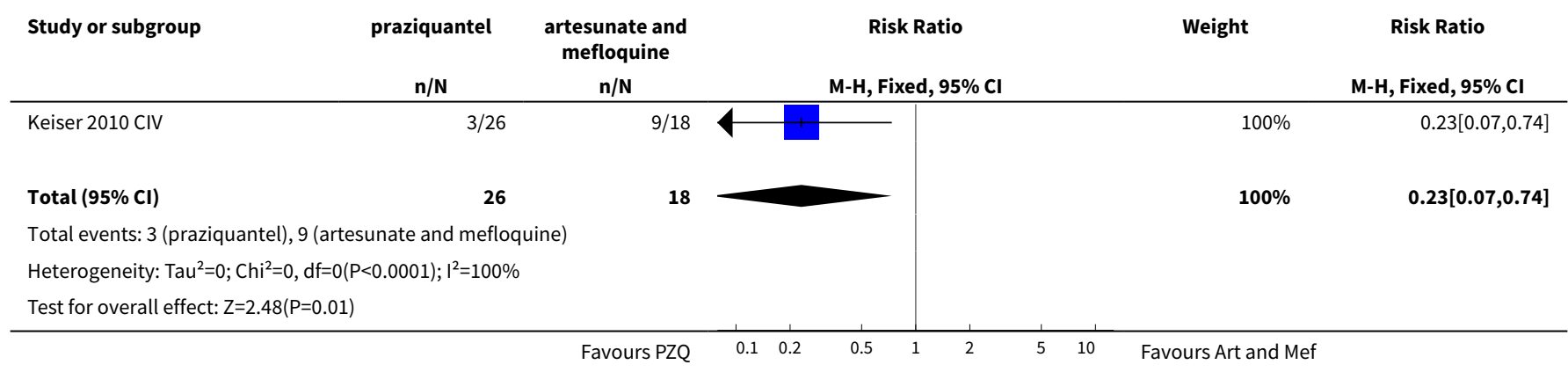

\section{Comparison 17. Praziquantel versus praziquantel and albendazole}

\begin{tabular}{lllll}
\hline Outcome or subgroup title & $\begin{array}{l}\text { No. of } \\
\text { studies }\end{array}$ & $\begin{array}{l}\text { No. of partici- } \\
\text { pants }\end{array}$ & Statistical method & Effect size \\
\hline 1 Parasitological failure & 1 & 193 & Risk Ratio (M-H, Random, 95\% Cl) & $0.90[0.62,1.30]$ \\
\hline
\end{tabular}

Analysis 17.1. Comparison 17 Praziquantel versus praziquantel and albendazole, Outcome 1 Parasitological failure.

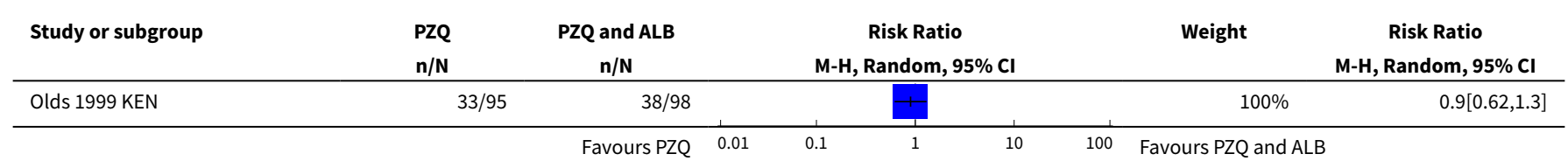




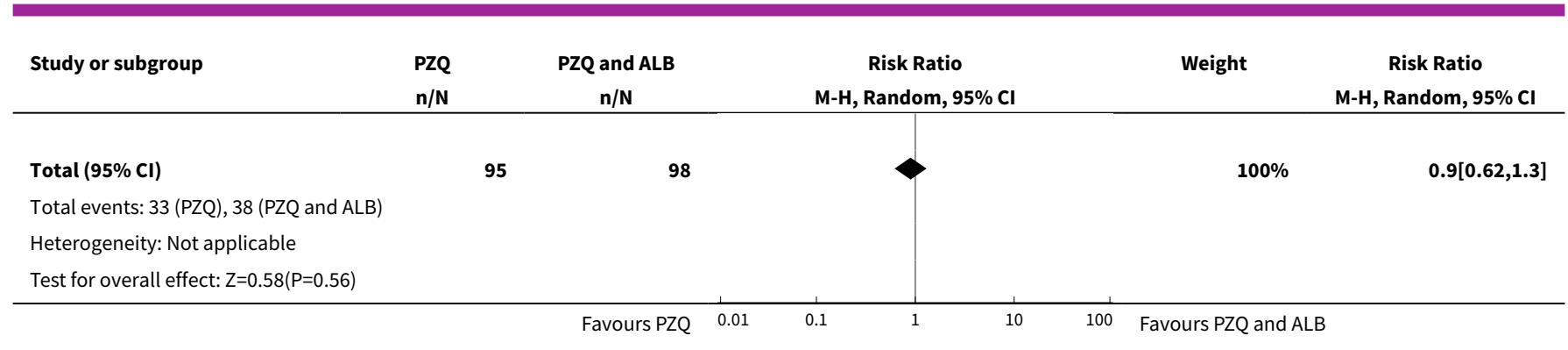

Comparison 18. Praziquantel versus praziquantel and artesunate

\begin{tabular}{|c|c|c|c|c|}
\hline Outcome or subgroup title & $\begin{array}{l}\text { No. of } \\
\text { studies }\end{array}$ & $\begin{array}{l}\text { No. of } \\
\text { partici- } \\
\text { pants }\end{array}$ & Statistical method & Effect size \\
\hline $\begin{array}{l}1 \text { Parasitological failure at } \\
\text { eight weeks }\end{array}$ & 2 & 265 & Risk Ratio (M-H, Fixed, 95\% Cl) & $1.62[1.01,2.60]$ \\
\hline 2 Haematuria at eight weeks & 1 & 177 & Risk Ratio (M-H, Fixed, 95\% Cl) & $1.45[0.85,2.50]$ \\
\hline 3 Adverse events & 1 & & Risk Ratio (M-H, Fixed, 95\% Cl) & Totals not selected \\
\hline 3.1 Abdominal pain & 1 & & Risk Ratio (M-H, Fixed, 95\% Cl) & $0.0[0.0,0.0]$ \\
\hline 3.2 Dizziness & 1 & & Risk Ratio (M-H, Fixed, 95\% Cl) & $0.0[0.0,0.0]$ \\
\hline 3.3 Headache & 1 & & Risk Ratio (M-H, Fixed, 95\% Cl) & $0.0[0.0,0.0]$ \\
\hline 3.4 Vomiting & 1 & & Risk Ratio (M-H, Fixed, 95\% Cl) & $0.0[0.0,0.0]$ \\
\hline 3.5 Fever & 1 & & Risk Ratio (M-H, Fixed, 95\% Cl) & $0.0[0.0,0.0]$ \\
\hline 3.6 Itching & 1 & & Risk Ratio (M-H, Fixed, 95\% Cl) & $0.0[0.0,0.0]$ \\
\hline 3.7 Cough & 1 & & Risk Ratio (M-H, Fixed, 95\% Cl) & $0.0[0.0,0.0]$ \\
\hline 3.8 Diarrhoea & 1 & & Risk Ratio (M-H, Fixed, 95\% Cl) & $0.0[0.0,0.0]$ \\
\hline 3.9 Chills & 1 & & Risk Ratio (M-H, Fixed, 95\% Cl) & $0.0[0.0,0.0]$ \\
\hline 3.10 Nausea & 1 & & Risk Ratio (M-H, Fixed, 95\% Cl) & $0.0[0.0,0.0]$ \\
\hline 3.11 Constipation & 1 & & Risk Ratio (M-H, Fixed, 95\% Cl) & $0.0[0.0,0.0]$ \\
\hline
\end{tabular}

Analysis 18.1. Comparison 18 Praziquantel versus praziquantel and artesunate, Outcome 1 Parasitological failure at eight weeks.

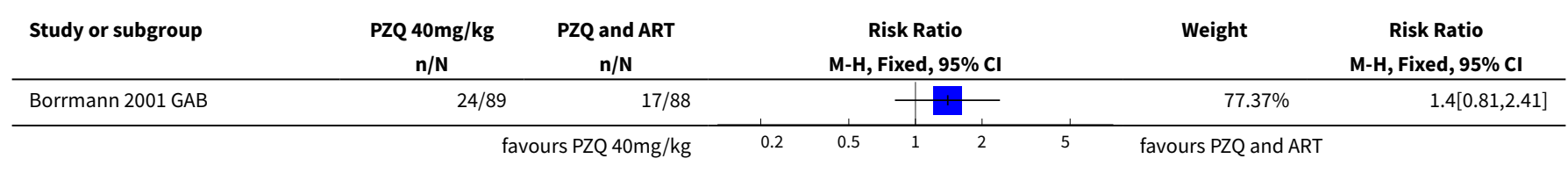




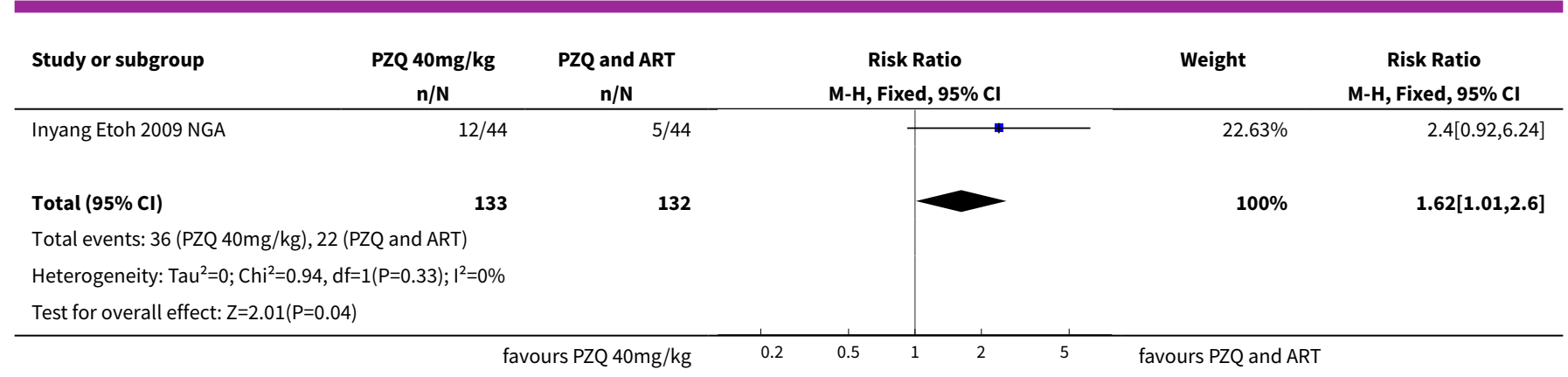

Analysis 18.2. Comparison 18 Praziquantel versus praziquantel and artesunate, Outcome 2 Haematuria at eight weeks.

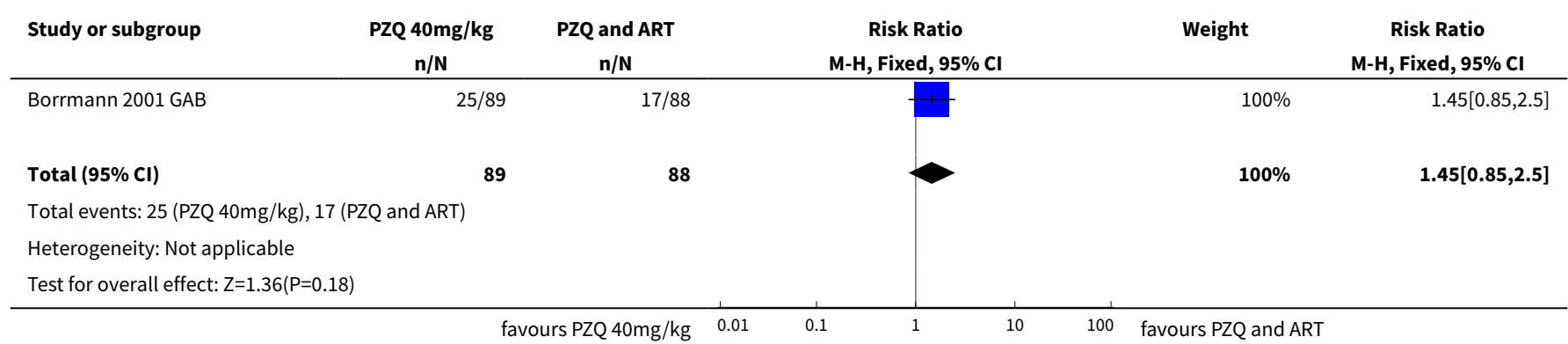

Analysis 18.3. Comparison 18 Praziquantel versus praziquantel and artesunate, Outcome 3 Adverse events.

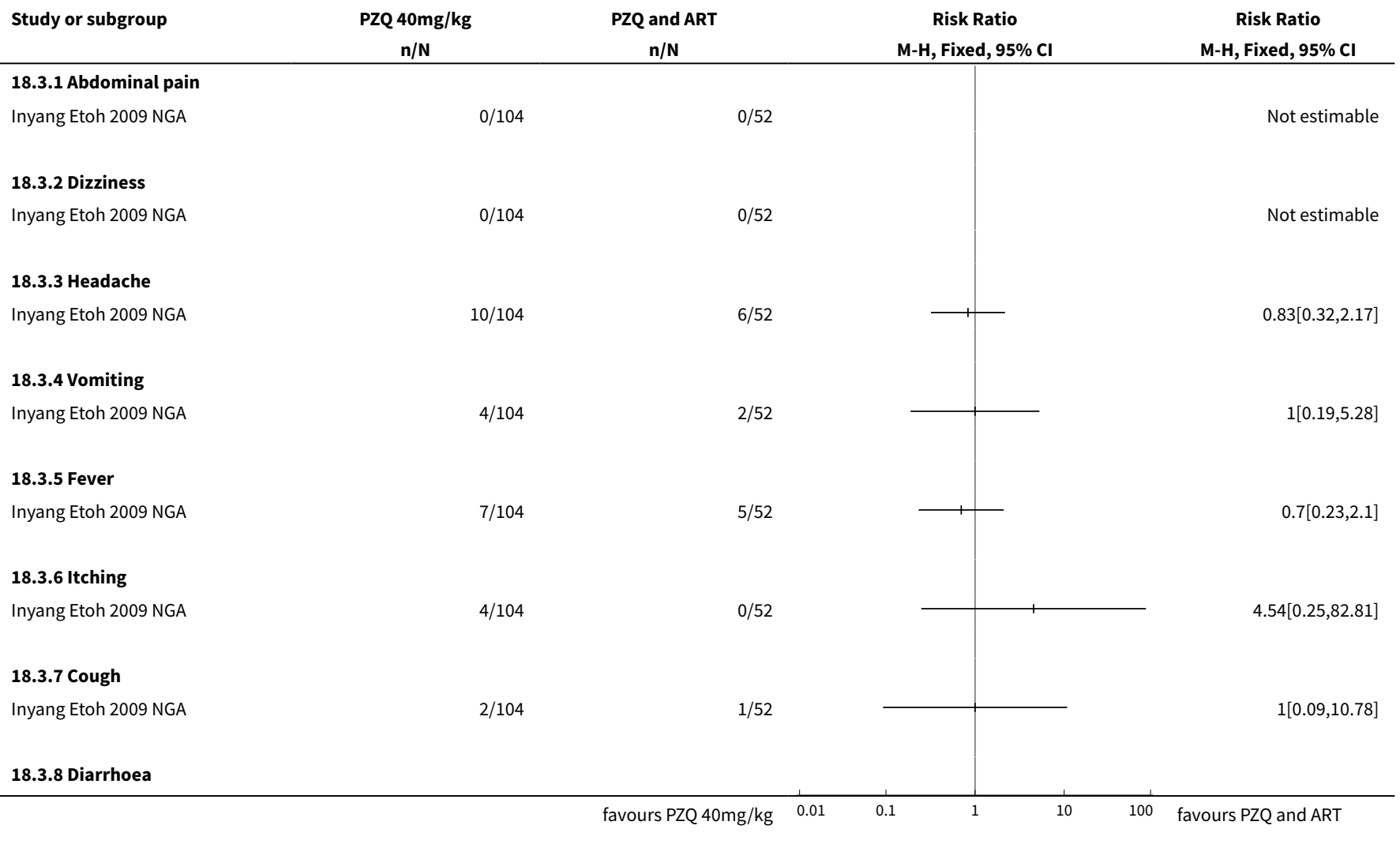




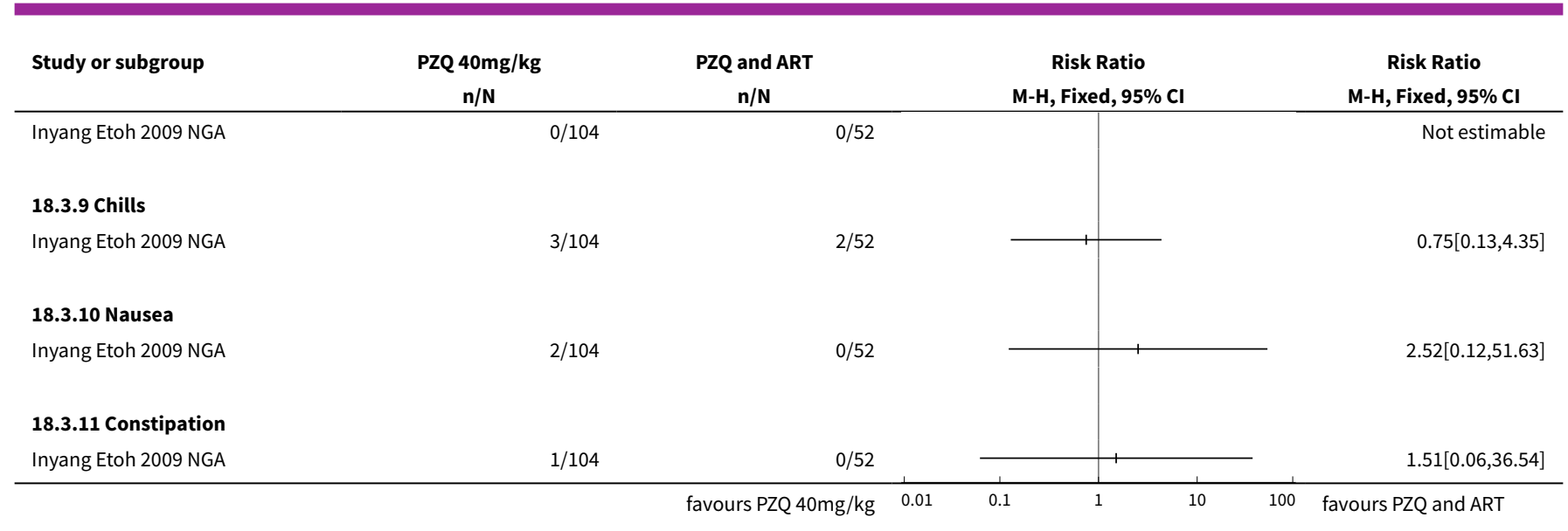

\section{ADDITIONAL TABLES}

Table 1. Population based treatment according to prevalence among schoolchildren (WHO)

\begin{tabular}{|c|c|c|c|}
\hline Category & $\begin{array}{l}\text { Prevalence among school-aged chil- } \\
\text { dren }\end{array}$ & Action to be taken & Comment \\
\hline $\begin{array}{l}\text { High-risk } \\
\text { community }\end{array}$ & $\begin{array}{l}50 \% \text { by parasitological methods (intesti- } \\
\text { nal or urinary schistosomiasis; } \\
\text { or } \\
30 \% \text { by questionnaire for visible haema- } \\
\text { turia } \\
\text { (urinary schistosomiasis) }\end{array}$ & $\begin{array}{l}\text { Treat all school-age children (en- } \\
\text { rolled and not enrolled) once a year }\end{array}$ & $\begin{array}{l}\text { Also treat adults considered to } \\
\text { be at risk (from special groups } \\
\text { to entire communities living in } \\
\text { endemic areas) }\end{array}$ \\
\hline $\begin{array}{l}\text { Moder- } \\
\text { ate-risk com- } \\
\text { munity }\end{array}$ & $\begin{array}{l}>10 \text { to }<50 \% \text { by parasitological meth- } \\
\text { ods (intestinal and urinary schistosomi- } \\
\text { asis); or } \\
30 \% \text { by questionnaire for visible haema- } \\
\text { turia (urinary schistosomiasis) }\end{array}$ & $\begin{array}{l}\text { Treat all school-age children (en- } \\
\text { rolled or not enrolled) once every two } \\
\text { years }\end{array}$ & $\begin{array}{l}\text { Also treat adults considered to } \\
\text { be at risk (special groups only) }\end{array}$ \\
\hline $\begin{array}{l}\text { Low-risk } \\
\text { community }\end{array}$ & $\begin{array}{l}<10 \% \text { by parasitological methods (in- } \\
\text { testinal and urinary schistosomiasis) }\end{array}$ & $\begin{array}{l}\text { Treat all school-age children } \\
\text { (enrolled and not enrolled) twice dur- } \\
\text { ing their primary schooling age } \\
\text { (for example, once on of suspected } \\
\text { cases } \\
\text { entry and once on exit) }\end{array}$ & $\begin{array}{l}\text { Praziquantel should be avail- } \\
\text { able in dispensaries and clinics } \\
\text { for treatment of suspected cas- } \\
\text { es. }\end{array}$ \\
\hline
\end{tabular}

Table 2. Definion of cure, reporting and calculation of egg counts

\begin{tabular}{llll}
\hline Study ID Definition cure & $\begin{array}{l}\text { Report- } \\
\text { ing of egg }\end{array}$ & Methods to calculate egg counts Comment
\end{tabular}


Table 2. Definion of cure, reporting and calculation of egg counts (Continued)

counts/10

mL urine

\begin{tabular}{|c|c|c|c|c|}
\hline $\begin{array}{l}\text { Abden Ab- } \\
\text { di } 1989 \\
\text { SOM }\end{array}$ & $\begin{array}{l}\text { Patients without schistosome } \\
\text { eggs in their urine after treat- } \\
\text { ment }\end{array}$ & $\begin{array}{l}\text { Mean } \\
\text { (SD), \% ER }\end{array}$ & Not reported & $\begin{array}{l}\text { No hatching test em- } \\
\text { ployed, cured might be } \\
\text { underestimated becaus } \\
\text { of dead eggs }\end{array}$ \\
\hline
\end{tabular}

\begin{tabular}{llll}
\hline $\begin{array}{l}\text { Al Aska } \\
\text { 1990 SAU }\end{array}$ & $\begin{array}{l}\text { Clinical improvement } \\
\text { Disappearance of ova from the } \\
\text { urine on three successive exami- } \\
\text { nations }\end{array}$ & $\begin{array}{l}\text { Mean, } \\
\text { range }\end{array}$ & Not reported \\
\hline Basra & $\begin{array}{l}\text { Three consecutive urine samples } \\
\text { without presence of eggs }\end{array}$ & $\begin{array}{l}\text { Median, } \\
\text { interquar- } \\
\text { tile range }\end{array}$ & Not reported \\
\hline
\end{tabular}

\begin{tabular}{|c|c|c|c|c|}
\hline $\begin{array}{l}\text { Befidi } \\
\text { Mengue } \\
1992 \text { CMR }\end{array}$ & Cure not reported & GMEC & Not reported & $\begin{array}{l}\mathrm{Hb} \text { and weight as out- } \\
\text { comes }\end{array}$ \\
\hline
\end{tabular}

Borrmann Two negative egg counts on two GMEC $2001 \mathrm{GAB}$ consecutive days
Arithmetric mean of two egg counts per participant before and after treatment including 0 egg counts (cured patients). Geometric means of these arithmetic means.
We received the data file from the study author

Day to day variation in egg counts explains $10 \%$ cure rate with placebo.

Quantitaive hatching test.

Geomet- At follow-up: If the first urine speciric mean men contained hatched miracidia, then miracidial random $10 \mathrm{~mL}$ samples were taken count from further bladder collections, the miracidial count was recorded, and the geometric mean of the counts was compared directly with the geometric mean of the pretreatment counts. if the first sedimented urine specimen was negative, then two further urine specimens taken on consecutive days were sedimented and examined.

\begin{tabular}{|c|c|c|c|c|}
\hline $\begin{array}{l}\text { de Jonge } \\
1990 \text { SDN }\end{array}$ & $\begin{array}{l}\text { No definition of cure given, pre- } \\
\text { sumably absence of urinary egg } \\
\text { excretion }\end{array}$ & $\begin{array}{l}\text { Minimum } \\
\text { and max- } \\
\text { imum } \\
\text { value, } \\
\text { median, } \\
90 \% \text { value }\end{array}$ & Not reported & $\begin{array}{l}\text { Excretion of eggs follow- } \\
\text { ing treatment }\end{array}$ \\
\hline $\begin{array}{l}\text { Inyang } \\
\text { Etoh } 2009 \\
\text { NGA }\end{array}$ & $\begin{array}{l}\text { No definition of cure given, cure } \\
\text { rates and egg reduction rates as } \\
\text { end points }\end{array}$ & Mean \pm SD & $\begin{array}{l}\text { "Treatment-related changes } \\
\text { in egg counts were investigated using } \\
\text { paired Student's t } \\
\text { test." }\end{array}$ & - \\
\hline $\begin{array}{l}\text { Jewsbury } \\
1976 \text { ZWE }\end{array}$ & No definition of cure given & $\begin{array}{l}\text { "median } \\
\text { urine egg } \\
\text { count" }\end{array}$ & Not reported & - \\
\hline $\begin{array}{l}\text { Kardaman } \\
1985 \text { SDN }\end{array}$ & $\begin{array}{l}\text { No definition of cure given, "neg- } \\
\text { ative" }\end{array}$ & GMEC & Not reported & $\begin{array}{l}\text { "It would appear that the } \\
\text { cure rate determined in } \\
\text { any trial is dependent } \\
\text { on the pretreatment egg }\end{array}$ \\
\hline
\end{tabular}

Drugs for treating urinary schistosomiasis (Review) 
Table 2. Definion of cure, reporting and calculation of egg counts (Continued)

count and on the ...urine examination techniques used."

\begin{tabular}{ll}
\hline Keiser & Absence of urinary egg excretion \\
& \\
& Cure rate (CR, defined as the per- \\
centage of children excreting no & S. haematobium eggs 26 days af- \\
& ter treatment among children \\
& with confirmed parasites at base- \\
& line)
\end{tabular}

GMEC

S. haematobium egg counts before and after treatment were averaged for every child (arithmetic mean) and the GM egg count for each treatment group was calculated. Because egg counts are over dispersed, they were logarithmically transformed log [count+1], and the GM was expressed as the antilogarithm of the mean.

Egg reduction rate (ERR) defined as reduction of geometric mean (GM) egg count among $S$. haematobium positive children after treatment, compared with the respective GM pretreatment.

The ERR was calculated as (1 - [GM egg count after treatment/GM egg counts at enrolment] x 100

\begin{tabular}{|c|c|c|c|c|}
\hline $\begin{array}{l}\text { King } 1989 \\
\text { KEN }\end{array}$ & No definition of cure given & $\begin{array}{l}\text { AMEC } \\
\text { GMEC }\end{array}$ & Not reported & $\begin{array}{l}\text { Infection was identified } \\
\text { and quantified by Nucle- } \\
\text { opore filtration }\end{array}$ \\
\hline $\begin{array}{l}\text { King } 1990 \\
\text { KEN }\end{array}$ & No definition of cure given & $\begin{array}{l}\text { AMEC } \\
\text { GMEC }\end{array}$ & Not reported & $\begin{array}{l}\text { Infection was identified } \\
\text { and quantified by Nucle- } \\
\text { opore filtration }\end{array}$ \\
\hline $\begin{array}{l}\text { King } 2002 \\
\text { KEN }\end{array}$ & Cure defined as egg-negative & GMEC & Not reported & - \\
\hline $\begin{array}{l}\text { McMahon } \\
1979 \text { TZA }\end{array}$ & $\begin{array}{l}\text { Probable cure rate: excretion of } \\
\text { no or only non viable eggs in the } \\
\text { urine }\end{array}$ & $\begin{array}{l}\text { GMEC, } \\
95 \% \text { confi- } \\
\text { dence lim- } \\
\text { it of the } \\
\text { mean }\end{array}$ & Not reported & - \\
\hline $\begin{array}{l}\text { McMahon } \\
1983 \text { TZA }\end{array}$ & $\begin{array}{l}\text { People were considered cured } \\
\text { when no eggs or non-viable eggs } \\
\text { were excreted in the urine }\end{array}$ & $\begin{array}{l}\text { Screen- } \\
\text { ing: } \\
\text { GMEC of } \\
\text { miracidia/10 } \\
\mathrm{mL} \text { urine } \\
\text { reduction } \\
\text { in egg ex- } \\
\text { cretion }\end{array}$ & $\begin{array}{l}\text { "In non cured cases the reduction of egg } \\
\text { excretion was calculated." }\end{array}$ & - \\
\hline $\begin{array}{l}\text { Mott } 1985 \\
\text { GHA }\end{array}$ & $\begin{array}{l}\text { Absence of S. haematobium eggs } \\
\text { in two random } 5 \mathrm{~mL} \text { samples of } \\
\text { urine from the same specimen }\end{array}$ & $\begin{array}{l}\text { GMEC } 5 \\
\text { mL urine } \\
\text { samples } \\
\text { reduction } \\
\text { in GMEC }\end{array}$ & Not reported & - \\
\hline $\begin{array}{l}\text { Olds } 1999 \\
\text { KEN }\end{array}$ & No definition given & GMEC & $\begin{array}{l}\text { "Egg counts are geometric means in } \\
\text { subjects who remained }\end{array}$ & - \\
\hline
\end{tabular}

Drugs for treating urinary schistosomiasis (Review) 
Table 2. Definion of cure, reporting and calculation of egg counts (Continued)

infected. Reduction in egg no. after treatment in infected children was sig-

nificant in all infections at 45 days."

\begin{tabular}{|c|c|c|c|c|}
\hline $\begin{array}{l}\text { Omer } \\
1981 \text { SDN }\end{array}$ & $\begin{array}{l}100 \% \text { reduction of egg excretion } \\
\text { (absence of egg excretion in the } \\
\text { urine) }\end{array}$ & GMEC & Not reported & $\begin{array}{l}\text { Only children with GMEC } \\
>60 / 10 \mathrm{~mL} \text { (in three egg } \\
\text { counts) included }\end{array}$ \\
\hline
\end{tabular}

or $98 \%$ egg reduction and neg

miracidial hatching test

\begin{tabular}{llll}
\hline Oyediran & No definition of cure given & GMEC & Not reported \\
1981 NGA & mean \pm SD &
\end{tabular}

Only children with GMEC $>60 / 10 \mathrm{~mL}$ (in three egg

counts) included

\begin{tabular}{|c|c|c|c|}
\hline $\begin{array}{l}\text { Pugh } 1983 \\
\text { MWI }\end{array}$ & No definition of cure given & $\begin{array}{l}\text { AMEC } \\
\% \text { egg } \\
\text { count re- } \\
\text { duction }\end{array}$ & $\begin{array}{l}\text { Percentage reduction in egg output was } \\
\text { determined by comparing the arith- } \\
\text { metic and geometric means of pooled } \\
\text { egg counts before and after treatment. } \\
\text { The geometric mean was obtained by } \\
\text { recording the logarithm of egg counts } \\
\text { and using the } n+1 \text { transformation for a } \\
\text { series of counts after treatment that in- } \\
\text { cluded zeros. }\end{array}$ \\
\hline
\end{tabular}

We did not use a hatching test to determine the viability of excreted ova since percentage reduction in egg output rather than parasitological cure was our main criterion of efficacy.

\begin{tabular}{|c|c|c|c|c|}
\hline $\begin{array}{l}\text { Rey } 1983 \\
\text { NER }\end{array}$ & No definition of cure given & $\begin{array}{l}\text { AMEC } \\
\text { "nombre } \\
\text { moyenne" } \\
\text { average } \\
\text { number }\end{array}$ & Not reported & $\begin{array}{l}\text { If possible, a hatching } \\
\text { test was that at the last } \\
\text { control ( } 6 \text { months) }\end{array}$ \\
\hline $\begin{array}{l}\text { Rey } 1984 \\
\text { NER }\end{array}$ & $\begin{array}{l}\text { No definition of cure given, "neg- } \\
\text { ativation" }\end{array}$ & $\begin{array}{l}\text { AMEC } \\
\text { moyenne } \\
\text { des nom- } \\
\text { bres } \\
\text { d'oeuf- } \\
\text { s/10 mL } \\
\text { urine } \\
\text { Number } \\
\text { average }\end{array}$ & Not reported & - \\
\hline $\begin{array}{l}\text { Sacko } \\
2009 \mathrm{MLI}\end{array}$ & $\begin{array}{l}\text { The } \\
\text { cure rate was calculated as the } \\
\text { proportion of infected individu- } \\
\text { als who became parasitological- } \\
\text { ly negative ( } 0 \text { egg } / 10 \mathrm{~mL} \text { urine } \\
\text { based on three urine samples) at } \\
\text { three months post treatment }\end{array}$ & GMEC & $\begin{array}{l}\text { Individual egg counts were } \\
\text { calculated as the mean number of eggs } \\
\text { per } 10 \mathrm{~mL} \text { of urine in the three urine } \\
\text { samples. To compare the effect of the } \\
\text { treatment on the intensity of the infec- } \\
\text { tion at } 3 \text {, } \\
6 \text { and } 18 \text { months geometric mean } \\
\text { egg/ } 10 \mathrm{~mL} \text { for all urine samples exam- } \\
\text { ined for } S \text {. haematobium eggs were cal- } \\
\text { culated as log } 10(x+1) \text { to allow egg count } \\
\text { of } \\
0 \text { to be included in the analysis. }\end{array}$ & - \\
\hline
\end{tabular}


Table 2. Definion of cure, reporting and calculation of egg counts (Continued)

\begin{tabular}{llll} 
Stephen- & no definition of cure given & AMEC & Not reported \\
son 1985 & & \\
KEN & & \\
\hline $\begin{array}{l}\text { Stephen- } \\
\text { son } 1989\end{array}$ & AMEC & Not reported \\
KEN & GMEC &
\end{tabular}

\begin{tabular}{|c|c|c|c|c|}
\hline $\begin{array}{l}\text { Taylor } \\
1988 \text { ZWE }\end{array}$ & $\begin{array}{l}\text { Cure defined as negative egg } \\
\text { counts } \\
\text { "infections as were cured by } \\
\text { a negative GMEC at } 1,3 \text { and } 6 \\
\text { months" }\end{array}$ & GMEC & Not reported & $\begin{array}{l}\text { "in cases were only one } \\
\text { egg was found in three } \\
\text { (urine) examinations the } \\
\text { egg count was always } \\
\text { taken as positive." }\end{array}$ \\
\hline $\begin{array}{l}\text { Tchuente } \\
2004 \text { CMR }\end{array}$ & $\begin{array}{l}\text { The parasitologic cure rates were } \\
\text { calculated as the proportion } \\
\text { of children excreting eggs at the } \\
\text { first survey before treatment } \\
\text { and who were not excreting eggs } \\
\text { in their urine after treatment. }\end{array}$ & GMEC & $\begin{array}{l}\text { Geometric mean (GM) values of all } \\
\text { individuals were used to assess average } \\
\text { egg counts of each group. The GM was } \\
\text { calculated as the antilogarithm of the } \\
\text { mean of all log transformed egg counts } \\
+1 . \\
\text { The intensity reduction rate was calcu- } \\
\text { lated as [ } 1 \text { - (GM egg counts per } 10 \\
\text { mL of urine after treatment/GM egg } \\
\text { counts per } 10 \mathrm{~mL} \text { before treatment)] } \\
100\end{array}$ & $\begin{array}{l}\text { The parasitological cure } \\
\text { rates were calculated as } \\
\text { the proportion of chil- } \\
\text { dren excreting eggs at } \\
\text { the first survey before } \\
\text { treatment and who were } \\
\text { not excreting eggs in } \\
\text { their urine after treat- } \\
\text { ment. }\end{array}$ \\
\hline $\begin{array}{l}\text { van den } \\
\text { Biggelaar } \\
02 \mathrm{GAB}\end{array}$ & $\begin{array}{l}\text { Negative for both eggs and circu- } \\
\text { lating antigen } \\
\text { failure: pos. for eggs or circulat- } \\
\text { ing antigen }\end{array}$ & $\begin{array}{l}\text { GMEC in- } \\
\text { terquar- } \\
\text { tile range }\end{array}$ & Not reported & - \\
\hline $\begin{array}{l}\text { Wilkins } \\
1987 \text { GMB }\end{array}$ & No definition of cure given & GMEC & $\begin{array}{l}\text { When appropriate a } \log _{10} \text { transforma- } \\
\text { tion was used in statistical analysis to } \\
\text { make their skewed distribution approx- } \\
\text { imate to normal. This was reversed for } \\
\text { the presentation of results to give a geo- } \\
\text { metric mean which included zero val- } \\
\text { ues. }\end{array}$ & - \\
\hline
\end{tabular}




\begin{tabular}{|c|c|c|c|c|c|c|c|c|c|c|}
\hline \multirow[t]{3}{*}{ Study ID } & \multirow{3}{*}{$\begin{array}{l}\text { Sub- } \\
\text { group }\end{array}$} & \multirow{3}{*}{$\begin{array}{l}\text { Time- } \\
\text { point }\end{array}$} & \multirow[t]{3}{*}{ Measure } & \multicolumn{3}{|c|}{ Praziquantel $40 \mathrm{mg} / \mathrm{kg}$ single dose } & \multicolumn{3}{|l|}{ Placebo } & \multirow{3}{*}{$\begin{array}{l}P \text { value differ- } \\
\text { ence between } \\
\text { groups }\end{array}$} \\
\hline & & & & \multicolumn{2}{|l|}{$\begin{array}{l}\text { Egg count/10 mL } \\
\text { (Range/95\% Cl) } \\
\mathrm{N}\end{array}$} & \multirow[t]{2}{*}{$\begin{array}{l}\% \\
\text { egg } \\
\text { re- } \\
\text { duc- } \\
\text { tion }\end{array}$} & \multicolumn{2}{|l|}{$\begin{array}{l}\text { Egg count/10 mL } \\
\text { (Range/95\% Cl) } \\
\mathrm{N}\end{array}$} & \multirow[t]{2}{*}{$\begin{array}{l}\text { \% egg re- } \\
\text { duction }\end{array}$} & \\
\hline & & & & Baseline & Follow-up & & Baseline & Follow-up & & \\
\hline $\begin{array}{l}\text { de Jonge } 1990 \\
\text { SDN }\end{array}$ & - & $\begin{array}{l}1 \\
\text { month }\end{array}$ & Median & $\begin{array}{l}66 \\
N=48\end{array}$ & $\begin{array}{l}1 \\
N=40\end{array}$ & 98.5 & $\begin{array}{l}124 \\
N=21\end{array}$ & $\begin{array}{l}58 \\
N=18\end{array}$ & 53.2 & $\begin{array}{l}P=0.29 \\
\text { not significant }\end{array}$ \\
\hline $\begin{array}{l}\text { McMahon } \\
1979 \text { TZA }\end{array}$ & - & $\begin{array}{l}1 \\
\text { month }\end{array}$ & $\begin{array}{l}\text { Miracidial } \\
\text { count } \\
(95 \% \mathrm{Cl})\end{array}$ & $\begin{array}{l}288.4(33.2 \text { to } 2508.9) \\
N=32\end{array}$ & $\begin{array}{l}1.1(0 \text { to } \\
8.3) \mathrm{N}=30\end{array}$ & 99.6 & $\begin{array}{l}324.9 \\
(22.1 \text { to } 4783.3) \\
N=37\end{array}$ & $\begin{array}{l}187.5 \\
(6.3 \text { to } \\
5601.3) \\
N=29\end{array}$ & 42.3 & Not reported \\
\hline $\begin{array}{l}\text { Pugh } 1983 \\
\text { MWI }\end{array}$ & - & $\begin{array}{l}1 \\
\text { month }\end{array}$ & $\begin{array}{l}\text { GMEC } \\
\text { AMEC }\end{array}$ & $\begin{array}{l}385.5 \\
780.9 \\
N=97\end{array}$ & $\begin{array}{l}1.8 / \\
1.8\end{array}$ & $\begin{array}{l}99.5 \\
99.7\end{array}$ & $\begin{array}{l}136.8 \\
188.8 \\
N=52\end{array}$ & $\begin{array}{l}119.9 \\
437.2\end{array}$ & $\begin{array}{l}12.35 \\
\text { (GMEC) } \\
\\
-131.5 \\
\text { (AMEC) } \\
\text { (increase) }\end{array}$ & Not reported \\
\hline $\begin{array}{l}\text { Taylor } 1988 \\
\text { ZWE }\end{array}$ & $\begin{array}{l}\text { light } \\
\text { infec- } \\
\text { tions } \\
<50 / 10 \\
\mathrm{~mL}\end{array}$ & $\begin{array}{l}1 \\
\text { month }\end{array}$ & $\begin{array}{l}\text { GMEC } \\
\mathrm{N}=\text { (both light } \\
\text { and heavy) }\end{array}$ & $\begin{array}{l}15.1 \\
N=77 \\
\text { (both groups) }\end{array}$ & 0.4 & 99.7 & $\begin{array}{l}15.7 \\
N=90 \\
\text { (both groups) }\end{array}$ & 37.5 & $\begin{array}{l}-138 \\
\text { (increase) }\end{array}$ & Not reported \\
\hline & $\begin{array}{l}\text { heavy } \\
\text { infec- } \\
\text { tions } \\
< \\
100 / 10 \\
\mathrm{~mL}\end{array}$ & $\begin{array}{l}1 \\
\text { month }\end{array}$ & $\begin{array}{l}\text { GMEC } \\
\mathrm{N}=\text { (both light } \\
\text { and heavy) }\end{array}$ & $\begin{array}{l}204.7 \\
N=77 \\
\text { (both groups) }\end{array}$ & 4.0 & 98.1 & $\begin{array}{l}191.9 \\
N=90 \\
\text { (both groups) }\end{array}$ & 147.0 & 23.39 & Not reported \\
\hline $\begin{array}{l}\text { Olds } 1999 \\
\text { KEN }\end{array}$ & - & $\begin{array}{l}45 \\
\text { days }\end{array}$ & GMEC & Not reported & 1.4 & - & $N=94$ & 29.8 & - & Not reported \\
\hline
\end{tabular}




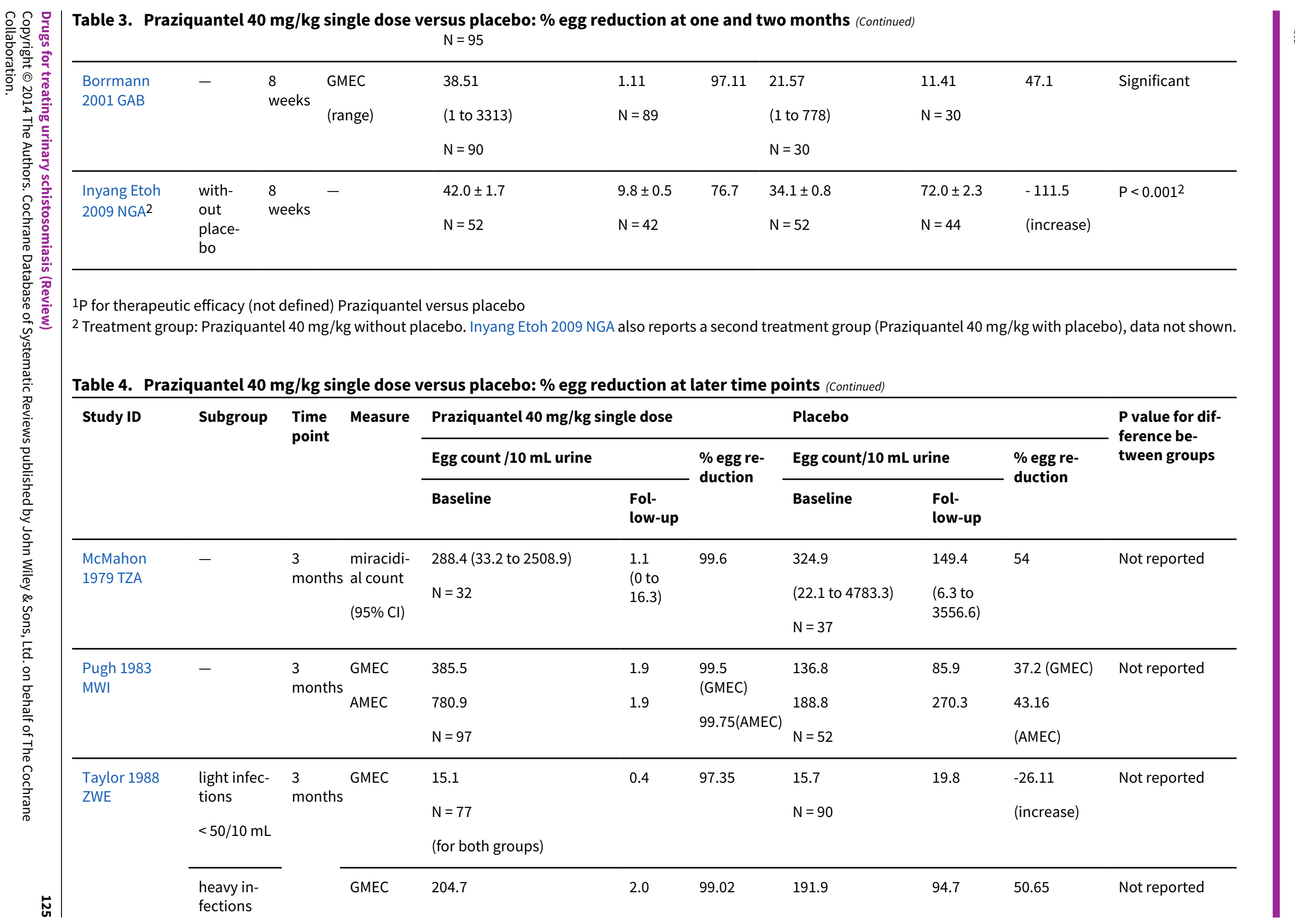




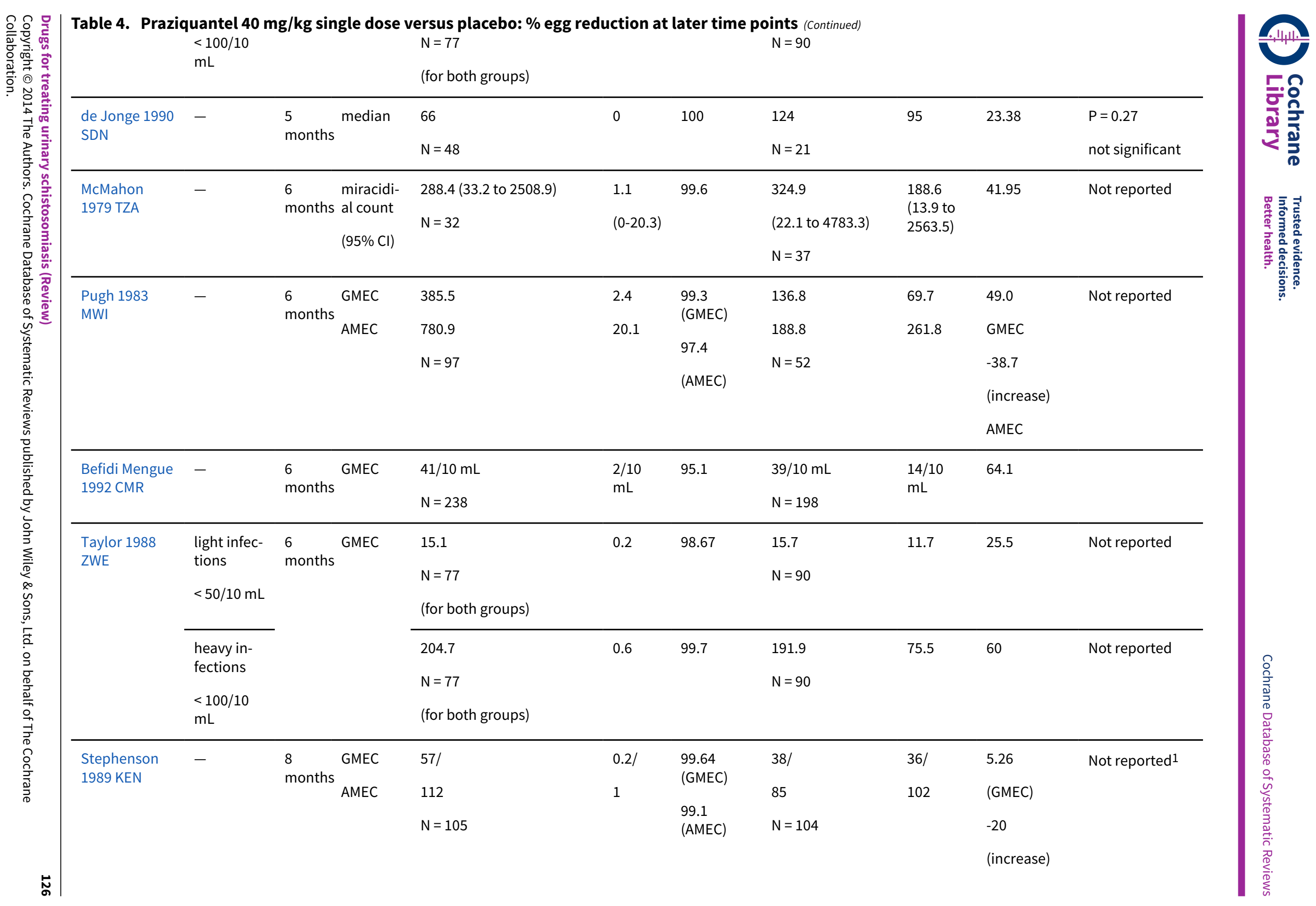


1Praziquantel $40 \mathrm{mg} / \mathrm{kg}$ single dose: significant egg reduction in praziquantel group (before, after treatment) $\mathrm{P}<0.0002$. no significant reduction in the placebo group (before, after treatment).

Table 5. Praziquantel $40 \mathrm{mg} / \mathbf{k g}$ single dose versus $30 \mathrm{mg} / \mathrm{kg}$ single dose: $\%$ egg reduction (Continued)

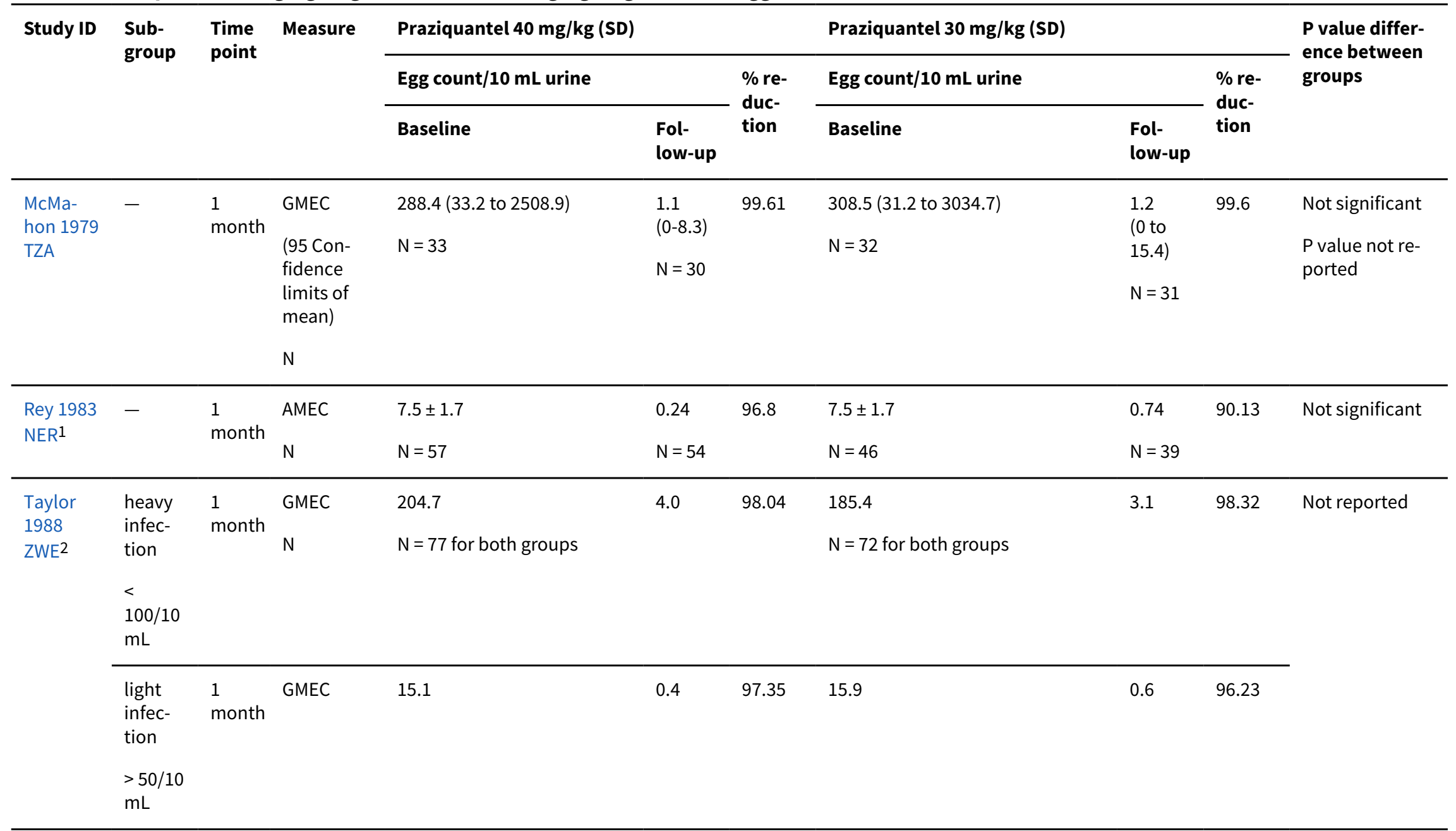




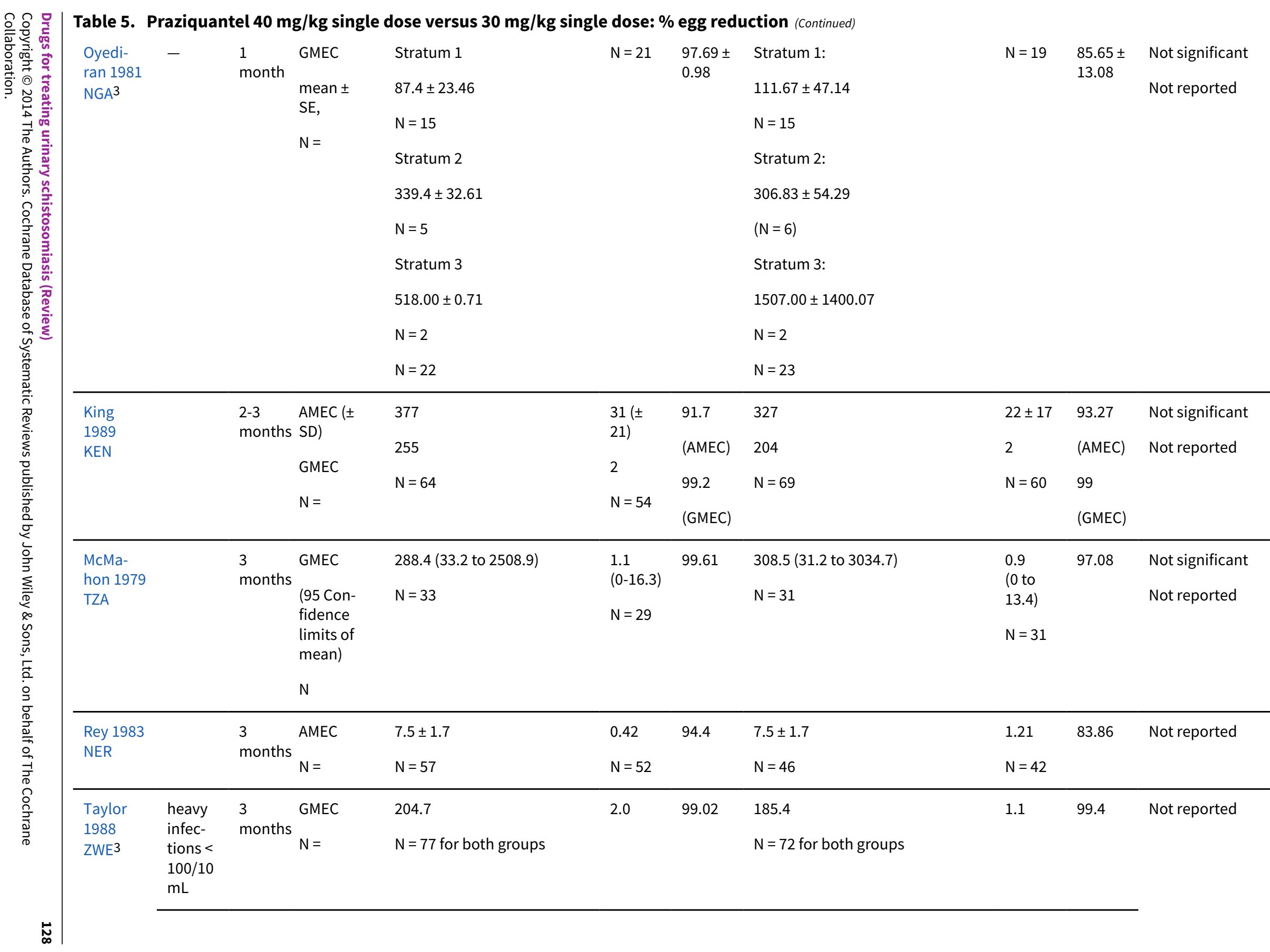




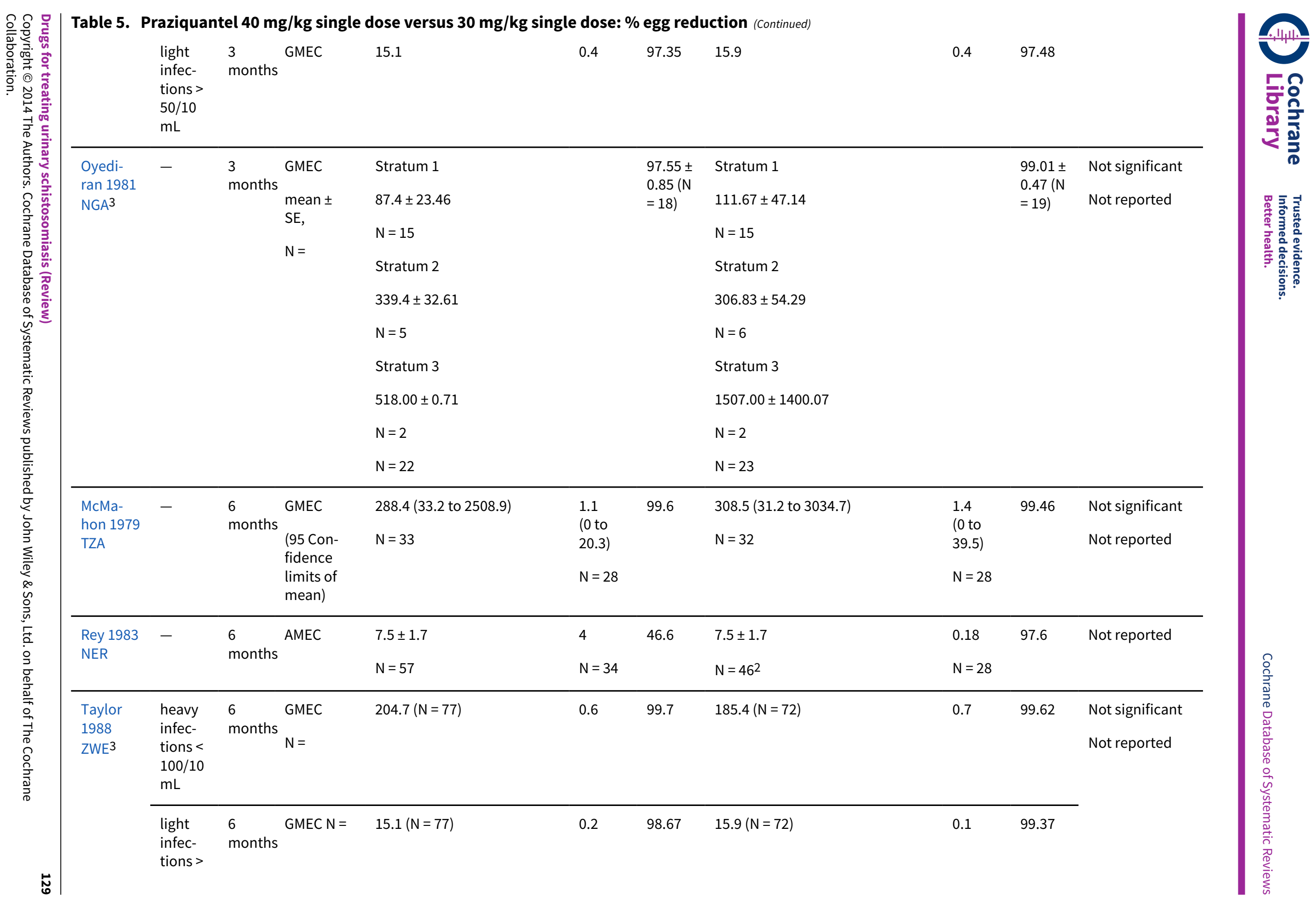




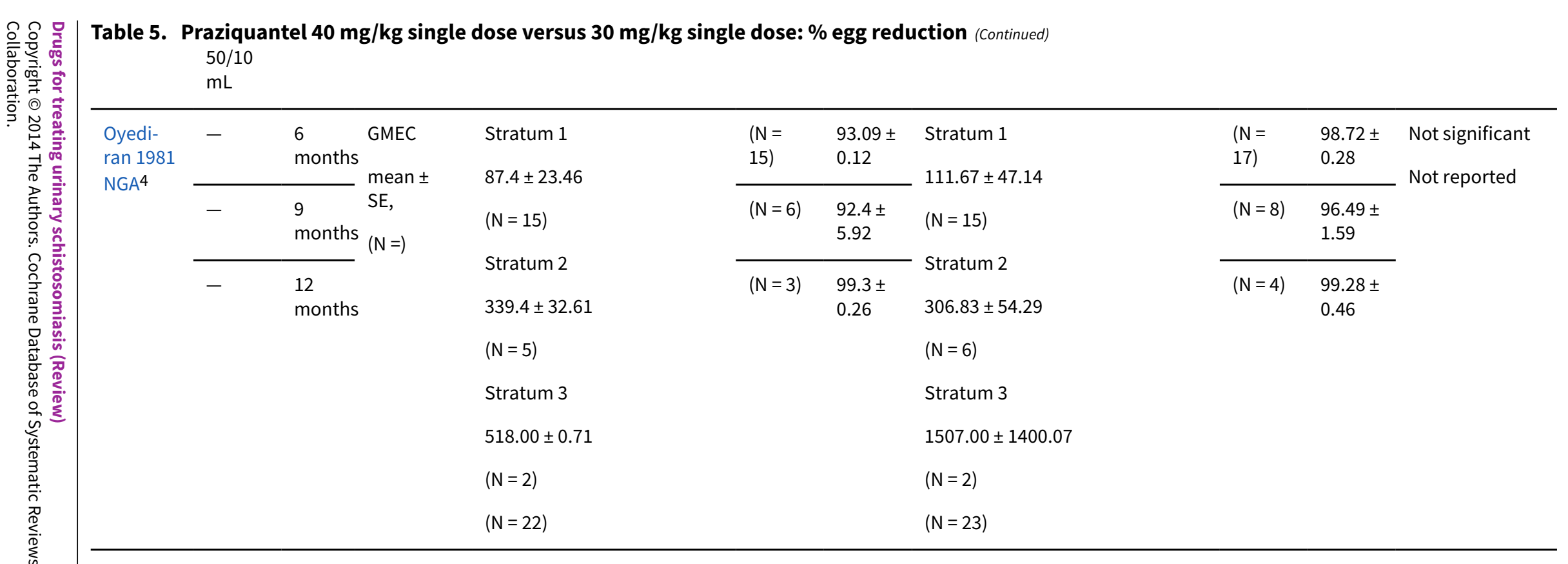

1Baseline data not reported separately per group.

2 A reduction as low as $46 \%$ after praziquantel $40 \mathrm{mg} / \mathrm{kg}$ was not observed by any other study that reported this outcome. At six months, five other studies reported $\%$ egg reduction above $90 \%$ (see Table 4 and Table 5)

3 Heavy and light infections together; $\mathrm{N}=77$ for Praziquantel $40 \mathrm{mg} / \mathrm{kg}$ and $\mathrm{N}=72$ for Praziquantel $30 \mathrm{mg} / \mathrm{kg}$.

$4 \mathrm{GMEC} / 10 \mathrm{~mL}$ urine, stratum 1: 60 to 250 , stratum 2: 251 to 500 , stratum $3>500$.

Table 6. Praziquantel $40 \mathrm{mg} / \mathrm{kg}$ multiple doses versus single dose: \% egg reduction (Continued)

\begin{tabular}{|c|c|c|c|c|c|c|c|c|c|}
\hline \multirow[t]{2}{*}{ Study ID } & \multirow{2}{*}{$\begin{array}{l}\text { Time } \\
\text { point }\end{array}$} & \multirow[t]{2}{*}{ Measure } & \multicolumn{2}{|c|}{ Praziquantel $40 \mathrm{mg} / \mathrm{kg}$ single dose } & \multirow{2}{*}{$\begin{array}{l}\% \text { egg } \\
\text { reduc- } \\
\text { tion }\end{array}$} & \multicolumn{2}{|c|}{ Praziquantel $40 \mathrm{mg} / \mathrm{kg}$ multiple doses } & \multirow{2}{*}{$\begin{array}{l}\% \text { egg } \\
\text { reduc- } \\
\text { tion }\end{array}$} & \multirow[t]{2}{*}{ Comments } \\
\hline & & & \multicolumn{2}{|c|}{ Egg count/10 mL } & & \multicolumn{2}{|c|}{ Egg count $/ 10 \mathrm{~mL}$} & & \\
\hline \multirow{2}{*}{$\begin{array}{l}\text { van den Bigge- } \\
\text { laar } 02 \mathrm{GAB}^{1}\end{array}$} & 2 years & GMEC & 47 & $9(2-45)$ & 80.85 & 47 & $2(1-3)$ & 95.74 & Significant \\
\hline & & (IQR) & $N=45$ & & & $N=45$ & & & $P=0.002$ \\
\hline
\end{tabular}

1Baseline egg counts not reported separately per treatment group; no difference at baseline stated. Praziquantel $40 \mathrm{mg} / \mathrm{kg}$ given every $3 \mathrm{months}$ over 2 years. Location: Gabon, endemic area. 
Table 7. Metrifonate $20 \mathrm{mg} / \mathrm{kg}$ given as divided dose versus placebo: $\%$ egg reduction (Continued)

\begin{tabular}{|c|c|c|c|c|c|c|c|c|c|}
\hline \multirow[t]{3}{*}{ Study ID } & \multirow[t]{3}{*}{$\begin{array}{l}\text { Time } \\
\text { point }\end{array}$} & \multirow[t]{3}{*}{ Measure } & \multicolumn{3}{|c|}{$\begin{array}{l}\text { Metrifonate } 21.5 \mathrm{mg}, 20 \mathrm{mg} / \mathrm{kg} \text { given } \\
\text { as divided dose }\end{array}$} & \multicolumn{3}{|c|}{ Placebo or no treatment } & \multirow[t]{3}{*}{$\begin{array}{l}P \text { value difference } \\
\text { between groups }\end{array}$} \\
\hline & & & \multicolumn{2}{|c|}{ Egg count $/ 10 \mathrm{~mL}$ urine } & \multirow{2}{*}{$\begin{array}{l}\% \text { egg } \\
\text { reduc- } \\
\text { tion }\end{array}$} & \multicolumn{2}{|c|}{$\begin{array}{l}\text { Egg count } / 10 \mathrm{~mL} \\
\text { urine }\end{array}$} & \multirow[t]{2}{*}{$\begin{array}{l}\text { \% egg re- } \\
\text { duction }\end{array}$} & \\
\hline & & & Baseline & $\begin{array}{l}\text { Fol- } \\
\text { low-up }\end{array}$ & & Baseline & $\begin{array}{l}\text { Fol- } \\
\text { low-up }\end{array}$ & & \\
\hline \multirow{5}{*}{$\begin{array}{l}\text { de Jonge } 1990 \\
\text { SDN1 }\end{array}$} & \multirow[t]{5}{*}{1 month } & median & 95 & 1 & 98.94 & 124 & 58 & 53.22 & Not significant \\
\hline & & & $N=38$ & $N=32$ & & $N=21$ & $\mathrm{~N}=18$ & & $P=0.29$ \\
\hline & & (reports min, max, 90th percentile & & & & & & & \\
\hline & & and median & & & & & & & \\
\hline & & of egg counts $/ 10 \mathrm{~mL}$ ) & & & & & & & \\
\hline \multirow{4}{*}{$\begin{array}{l}\text { Jewsbury } 1976 \\
\text { ZWE2 }\end{array}$} & \multirow[t]{2}{*}{11 weeks } & median & 101 & 0 & 100 & \multirow{4}{*}{$\begin{array}{l}26 \\
N=38\end{array}$} & \multirow[t]{4}{*}{60} & \multirow{4}{*}{$\begin{array}{l}-130.77 \\
\text { (increase) }\end{array}$} & Not reported \\
\hline & & $N=$ & $N=32$ & & & & & & \\
\hline & \multirow[t]{2}{*}{11 weeks } & median & 40 & 0 & 100 & & & & \\
\hline & & $N=$ & $N=23$ & & & & & & \\
\hline \multirow{5}{*}{$\begin{array}{l}\text { de Jonge } 1990 \\
\text { SDN1 }\end{array}$} & \multirow{5}{*}{$\begin{array}{l}5 \\
\text { months }\end{array}$} & median & 124 & 1 & 99.19 & 124 & 95 & 23.38 & Not significant \\
\hline & & $N=$ & $N=38$ & $N=32$ & & $N=21$ & $N=19$ & & $P=0.27$ \\
\hline & & (reports min, max, 90th percentile & & & & & & & \\
\hline & & and median & & & & & & & \\
\hline & & of egg counts $/ 10 \mathrm{~mL}$ ) & & & & & & & \\
\hline \multirow{2}{*}{$\begin{array}{l}\text { Stephenson } \\
1985 \text { KEN }^{3}\end{array}$} & \multirow{2}{*}{$\begin{array}{l}6 \\
\text { months }\end{array}$} & AMEC & 109 & 7 & 94 & 110 & 124 & -12.7 & Not reported \\
\hline & & $N=$ & $N=202$ & & & $N=198$ & & (increase) & \\
\hline
\end{tabular}

1 Metrifonate $2 \times 10 \mathrm{mg} / \mathrm{kg}$, dose interval two weeks. Placebo: multivitamins.

2Reports two groups with metrifonate $7.5 \mathrm{mg} \times 3$, dose interval two weeks. Control group: nil.

$\underset{\bullet}{\stackrel{\omega}{\bullet}}$

3 Metrifonate $3 \times 7.5 \mathrm{mg} / \mathrm{kg}$, dose interval one to two weeks. 
Table 8. Artesunate versus placebo: \% egg reduction (Continued)

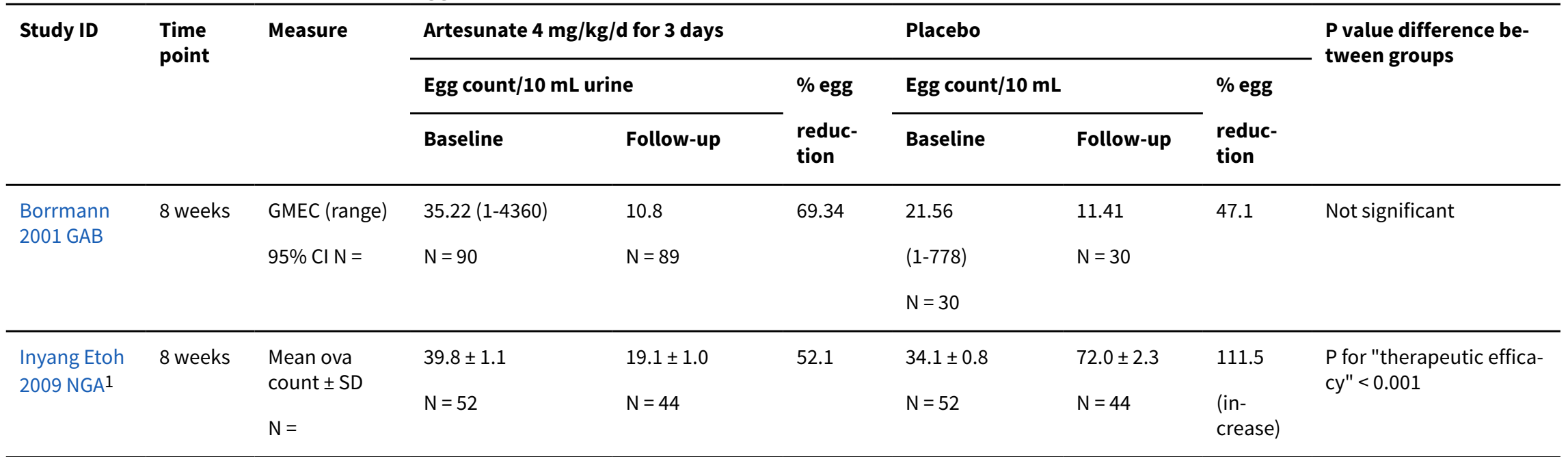

1Treatment group: Praziquantel 40 mg/kg without placebo. Inyang Etoh 2009 NGA also reports a second treatment group (Praziquantel 40 mg/kg with placebo), data not shown.

Table 9. Praziquantel and Artesunate versus Praziquantel: \% egg reduction (Continued)

\begin{tabular}{|c|c|c|c|c|c|c|c|c|c|}
\hline \multirow[t]{3}{*}{ Study ID } & \multirow[t]{3}{*}{$\begin{array}{l}\text { Time } \\
\text { point }\end{array}$} & \multirow[t]{3}{*}{ Measure } & \multicolumn{3}{|c|}{$\begin{array}{l}\text { Praziquantel } 40 \mathrm{mg} / \mathrm{kg} \text { single dose and artesunate } \\
4 \mathrm{mg} / \mathrm{kg} / \mathrm{d} \text { for } 3 \text { days }\end{array}$} & \multicolumn{3}{|c|}{ Praziquantel $40 \mathrm{mg} / \mathrm{kg}$ single dose } & \multirow{3}{*}{$\begin{array}{l}\text { P value differ- } \\
\text { ence between } \\
\text { groups }\end{array}$} \\
\hline & & & \multicolumn{2}{|c|}{ Egg count $/ 10 \mathrm{~mL}$} & \multirow{2}{*}{$\begin{array}{l}\% \text { egg re- } \\
\text { duction }\end{array}$} & \multicolumn{2}{|c|}{ Egg count/10 mL } & \multirow{2}{*}{$\begin{array}{l}\% \text { egg } \\
\text { reduc- } \\
\text { tion }\end{array}$} & \\
\hline & & & Baseline & Follow-up & & Baseline & Follow-up & & \\
\hline $\begin{array}{l}\text { Borrmann } \\
2001 \mathrm{GAB}\end{array}$ & 8 weeks & $\begin{array}{l}\begin{array}{l}\text { GMEC } \\
\text { (range), }\end{array} \\
(95 \% \mathrm{Cl}) \\
\mathrm{N}=\end{array}$ & $\begin{array}{l}31.5 \\
\text { (1 to } 3225) \\
\mathrm{N}=90\end{array}$ & $\begin{array}{l}0.36 \\
N=88\end{array}$ & 98.8 & $\begin{array}{l}38.51 \\
\text { (1 to } 3313 \text { ) } \\
\mathrm{N}=90\end{array}$ & $\begin{array}{l}1.11 \text { (0.7 to } 1.7 \text { ) } \\
\mathrm{N}=89\end{array}$ & 97.11 & Not significant \\
\hline $\begin{array}{l}\text { Inyang Etoh } \\
2009 \text { NGA }^{1}\end{array}$ & 8 weeks & $\begin{array}{l}\text { mean } \pm S D \\
N=\end{array}$ & $\begin{array}{l}62.2 \pm 2.1 \\
N=52\end{array}$ & $4.0( \pm 15.2) \mathrm{N}=44$ & 93.6 & $\begin{array}{l}39.8( \pm 1.1) \\
N=52\end{array}$ & $\begin{array}{l}19.1( \pm 1.0) \\
N=44\end{array}$ & 52.1 & Not reported \\
\hline
\end{tabular}



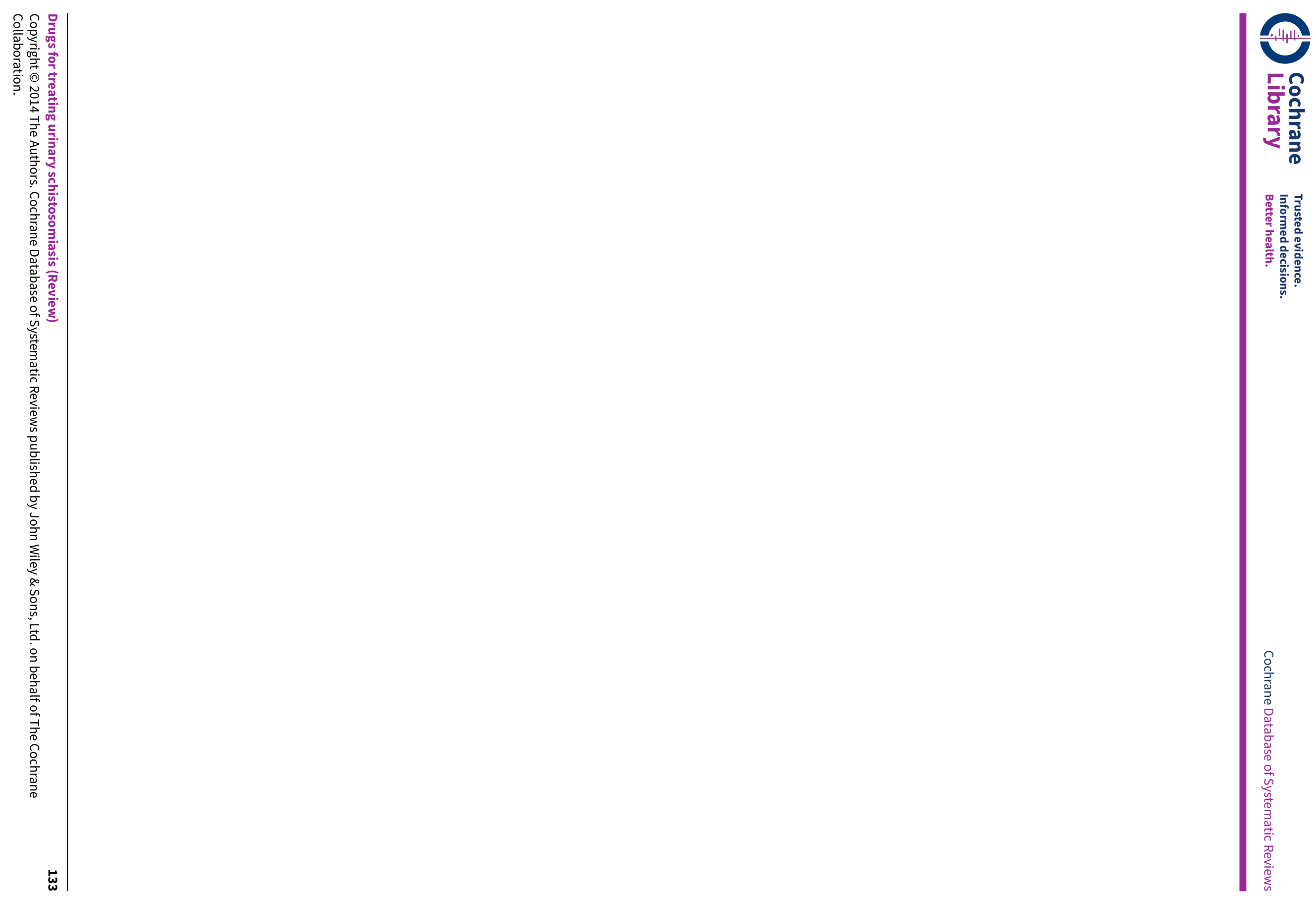


\section{APPENDICES}

\section{Appendix 1. Search strategy}

\begin{tabular}{|c|c|c|c|c|c|}
\hline $\begin{array}{l}\text { Search } \\
\text { set }\end{array}$ & CIDG SR* & CENTRAL & MEDLINE** & EMBASE $^{\star \star}$ & LILACS $^{\star \star}$ \\
\hline 1 & $\begin{array}{l}\text { Schistosoma } \\
\text { haematobium }\end{array}$ & $\begin{array}{l}\text { SCHISTOSOMIASIS } \\
\text { HAEMATOBIA }\end{array}$ & $\begin{array}{l}\text { SCHISTOSOMA } \\
\text { HAEMATOBIA }\end{array}$ & $\begin{array}{l}\text { SCHISTOSO- } \\
\text { MA-HAEMATOBIA }\end{array}$ & $\begin{array}{l}\text { Schistosoma haema- } \\
\text { tobium }\end{array}$ \\
\hline 2 & praziquantel & $\begin{array}{l}\text { urinary schistosomia- } \\
\text { sis }\end{array}$ & $\begin{array}{l}\text { urinary schistosomia- } \\
\text { sis }\end{array}$ & $\begin{array}{l}\text { urinary schistosomia- } \\
\text { sis }\end{array}$ & $\begin{array}{l}\text { urinary schistosomia- } \\
\text { sis }\end{array}$ \\
\hline 3 & metrifonate & 1 OR 2 & $1 \mathrm{OR} 2$ & $1 \mathrm{OR} 2$ & 1 or 2 \\
\hline 4 & albendazole & praziquantel & praziquantel & praziquantel & praziquantel \\
\hline 5 & artesunate & metrifonate & metrifonate & metrifonate & metrifonate \\
\hline 6 & artemether & albendazole & albendazole & albendazole & albendazole \\
\hline 7 & $2-6 / O R$ & artesunate & artesunate & artesunate & artesunate \\
\hline 8 & 1 AND 7 & artemether & artemether & artemether & artemether \\
\hline 9 & -- & $4-8 / O R$ & $4-8 / O R$ & $4-8 / O R$ & $4-8 / O R$ \\
\hline 10 & -- & 3 AND 9 & 3 AND 9 & 3 AND 9 & 3 AND 9 \\
\hline 11 & -- & -- & Limit 10 to human & Limit 10 to human & -- \\
\hline
\end{tabular}

*Cochrane Infectious Diseases Group Specialized Register.

${ }^{\star \star}$ Search terms used in combination with the search strategy for retrieving trials developed by The Cochrane Collaboration (Lefebvre 2008); upper case: MeSH or EMTREE heading; lower case: free text term.

\section{Appendix 2. Appendix: Additional tables for egg reduction data}

Praziquantel $40 \mathrm{mg} / \mathrm{kg}$ single dose versus placebo: parasitological failure stratified by severity of infection

\begin{tabular}{|c|c|c|c|c|c|c|}
\hline \multirow[t]{2}{*}{ Trial ID } & \multirow[t]{2}{*}{$\begin{array}{l}\text { Time } \\
\text { point }\end{array}$} & \multirow[t]{2}{*}{ Stratification } & \multirow[t]{2}{*}{$\begin{array}{l}\text { GMEC or miracidial count/10 mL } \\
\text { urine }\end{array}$} & \multicolumn{2}{|l|}{$\begin{array}{l}\text { Praziquantel } \\
40 \mathrm{mg} / \mathrm{kg} \text { single } \\
\text { dose }\end{array}$} & \multirow{2}{*}{$\begin{array}{l}\text { P value } \\
\text { differ- } \\
\text { ence be- } \\
\text { tween } \\
\text { groups }\end{array}$} \\
\hline & & & & $\begin{array}{l}\text { Parasitological } \\
\text { failure }\end{array}$ & $\begin{array}{l}\text { Parasito- } \\
\text { logical } \\
\text { failure }\end{array}$ & \\
\hline \multirow[t]{2}{*}{$\begin{array}{l}\text { Taylor } 1988 \\
\text { ZWE }\end{array}$} & \multirow[t]{2}{*}{1 month } & light & $\begin{array}{l}<100 \\
\mathrm{~N}=77 \text { for all strata }\end{array}$ & $37.7 \%$ & $100 \%$ & \multirow[t]{2}{*}{$\begin{array}{l}\text { Not re- } \\
\text { ported }\end{array}$} \\
\hline & & heavy & $>100$ & $91.7 \%$ & $100 \%$ & \\
\hline
\end{tabular}


(Continued)

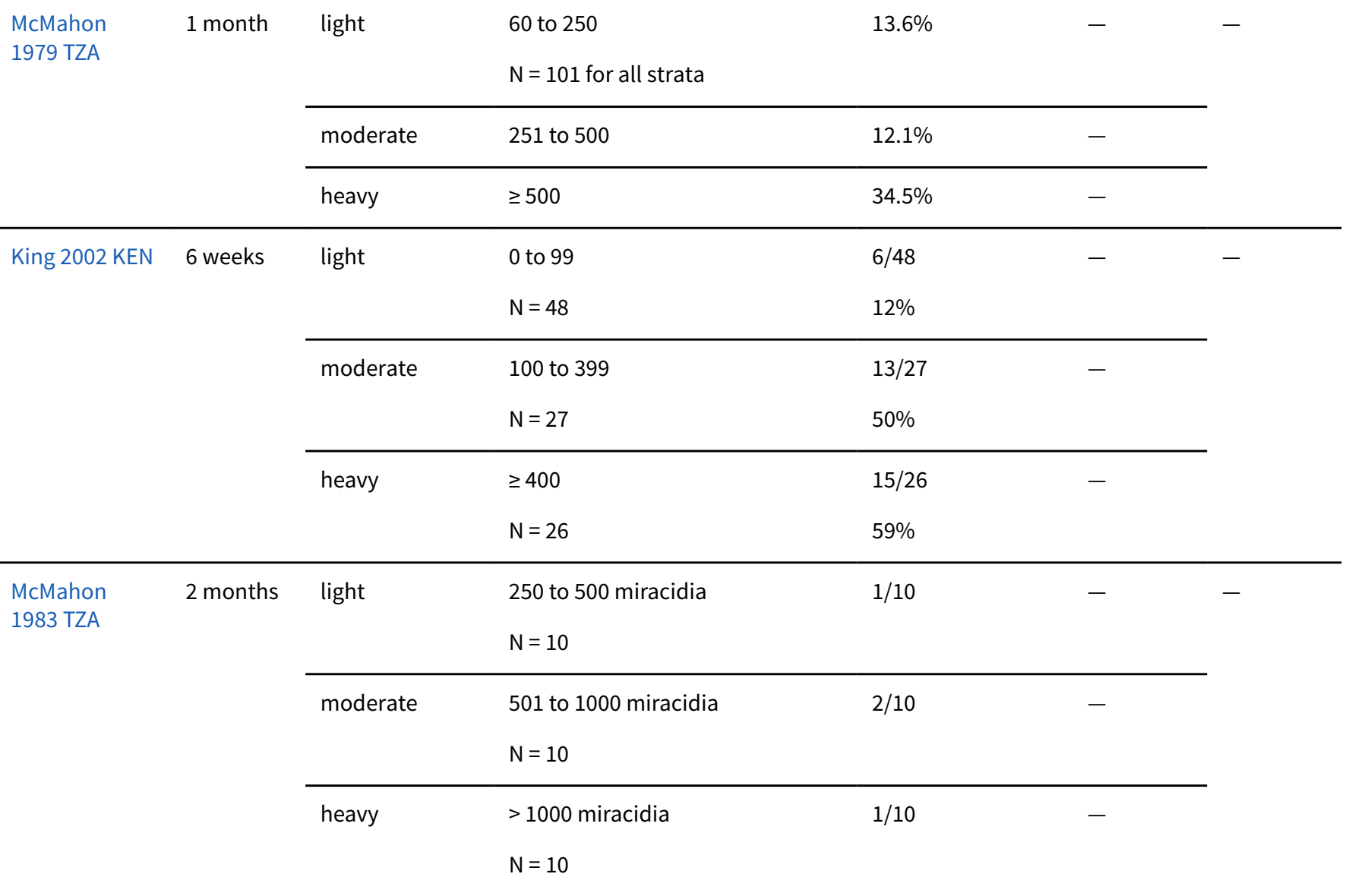

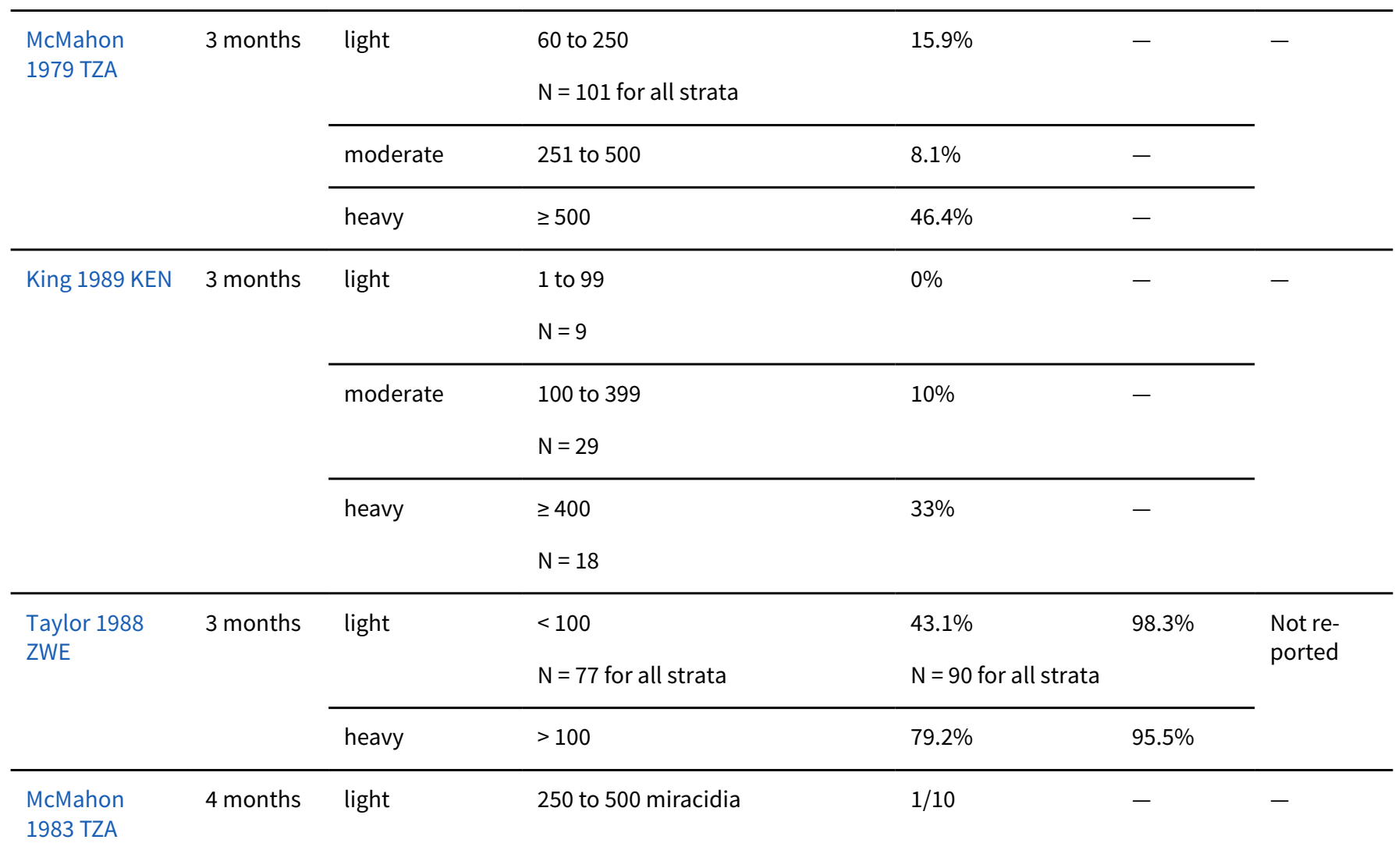


(Continued)

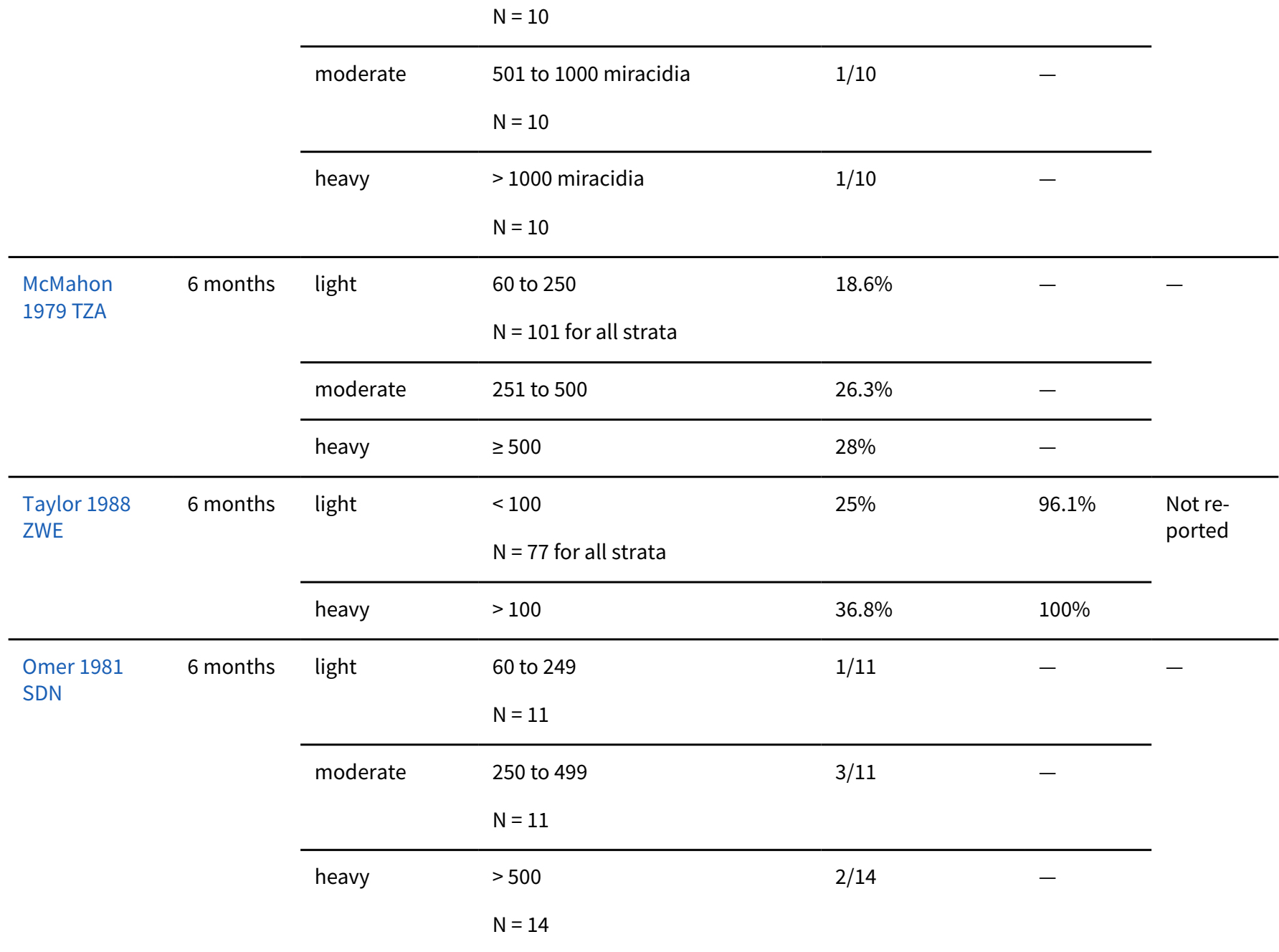

Praziquantel $40 \mathrm{mg} / \mathrm{kg}$ single dose versus placebo: $\%$ egg reduction stratified by severity of infection 


\begin{tabular}{|c|c|c|c|c|c|c|c|c|c|c|c|}
\hline \multicolumn{12}{|c|}{ ○े 일 } \\
\hline & \multirow[t]{3}{*}{ Trial ID } & \multirow{3}{*}{$\begin{array}{l}\text { Time } \\
\text { point }\end{array}$} & \multirow[t]{3}{*}{ Stratum } & \multirow{3}{*}{$\begin{array}{l}\text { By GMEC/10 mL/ } \\
\text { urine or by "egg } \\
\text { count" }\end{array}$} & \multicolumn{3}{|c|}{ Praziquantel 40 mg/kg single dose } & \multicolumn{3}{|l|}{ Placebo } & \multirow{3}{*}{$\begin{array}{l}P \\
\text { val- } \\
\text { ue } \\
\text { dif- } \\
\text { fer- } \\
\text { ence } \\
\text { be- } \\
\text { tween } \\
\text { groups }\end{array}$} \\
\hline 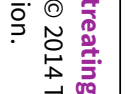 & & & & & \multicolumn{2}{|c|}{ GMEC/10 $\mathrm{mL}$ urine } & \multirow[t]{2}{*}{$\begin{array}{l}\text { \% egg re- } \\
\text { duction }\end{array}$} & \multicolumn{2}{|c|}{$\begin{array}{l}\text { GMEC/10 mL } \\
\text { urine }\end{array}$} & \multirow[t]{2}{*}{$\begin{array}{l}\text { \% egg re- } \\
\text { duction }\end{array}$} & \\
\hline 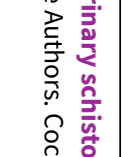 & & & & & Baseline & $\begin{array}{l}\text { Fol- } \\
\text { low-up }\end{array}$ & & Baseline & $\begin{array}{l}\text { Fol- } \\
\text { low-up }\end{array}$ & & \\
\hline 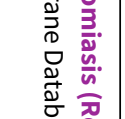 & \multirow[t]{4}{*}{$\begin{array}{l}\text { Pugh } 1983 \\
\text { MWI }\end{array}$} & \multirow[t]{4}{*}{$\begin{array}{l}1 \\
\text { month }\end{array}$} & light & 20 to 124 & $\begin{array}{l}51.7 \\
N=21\end{array}$ & 2.1 & 95.93 & $\begin{array}{l}52.7 \\
N=20\end{array}$ & 35.6 & 32.45 & \multirow{4}{*}{$\begin{array}{l}\text { Not } \\
\text { re- } \\
\text { port- } \\
\text { ed }\end{array}$} \\
\hline 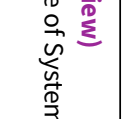 & & & moderate & 125 to 499 & $\begin{array}{l}234.7 \\
N=30\end{array}$ & 1.5 & 99.36 & $\begin{array}{l}248.0 \\
N=32\end{array}$ & 256.2 & $\begin{array}{l}-3.2 \% \text { (in- } \\
\text { crease) }\end{array}$ & \\
\hline 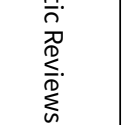 & & & heavy & 500 to 1999 & $\begin{array}{l}907.6 \\
N=38\end{array}$ & 1.7 & 99.86 & - & - & - & \\
\hline $\begin{array}{l}\sigma \\
\overline{\bar{v}} \\
\bar{D} \\
\frac{\sigma}{\sigma}\end{array}$ & & & very heavy & $>2000$ & $\begin{array}{l}3433.3 \\
N=8\end{array}$ & 2.8 & 99.9 & - & - & - & \\
\hline 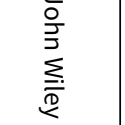 & \multirow[t]{2}{*}{$\begin{array}{l}\text { Taylor } 1988 \\
\text { ZWE1 }\end{array}$} & \multirow[t]{2}{*}{$\begin{array}{l}1 \\
\text { month }\end{array}$} & light & $<50$ & $\begin{array}{l}15.1 \\
N=\text { n.r. }\end{array}$ & 0.4 & 97.35 & 15.7 & 37.5 & $\begin{array}{l}138.85 \text { (in- } \\
\text { crease) }\end{array}$ & - \\
\hline 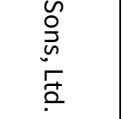 & & & heavy & $>100$ & $\begin{array}{l}204.7 \\
N=\text { n.r. }\end{array}$ & 4.0 & 98 & 191.9 & 147.0 & 23.4 & - \\
\hline $\begin{array}{l}\frac{\vec{\sigma}}{D} \\
\frac{D}{D}\end{array}$ & \multirow{3}{*}{$\begin{array}{l}\text { King } 2002 \\
\text { KEN }\end{array}$} & \multirow{3}{*}{$\begin{array}{l}6 \\
\text { weeks - }\end{array}$} & light & 0 to 99 & $N=48$ & 2.07 & 93 & - & - & - & - \\
\hline$\vec{\exists}$ & & & moderate & 100 to 399 & $N=27$ & 2.67 & 99 & - & - & - & - \\
\hline 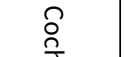 & & & heavy & $\geq 400$ & $N=26$ & 3.49 & 99.6 & - & - & - & - \\
\hline & \multirow[t]{2}{*}{$\begin{array}{l}\text { Pugh } 1983 \\
\text { MWI2 }\end{array}$} & \multirow[t]{2}{*}{$\begin{array}{l}3 \\
\text { months }\end{array}$} & light & 20 to 124 & $\begin{array}{l}51.7 \\
N=21\end{array}$ & 1.9 & 96.32 & $\begin{array}{l}52.7 \\
N=20\end{array}$ & 36.8 & 30.17 & \multirow{2}{*}{$\begin{array}{l}\text { Not } \\
\text { re- } \\
\text { port- } \\
\text { ed }\end{array}$} \\
\hline$\stackrel{\breve{\omega}}{\omega}$ & & & moderate & 125 to 499 & 234.7 & 1.9 & 99.19 & 248.0 & 145.7 & 41.25 & \\
\hline
\end{tabular}




\begin{tabular}{|c|c|c|c|c|c|c|c|c|c|c|c|c|}
\hline \multirow{5}{*}{\multicolumn{2}{|c|}{ 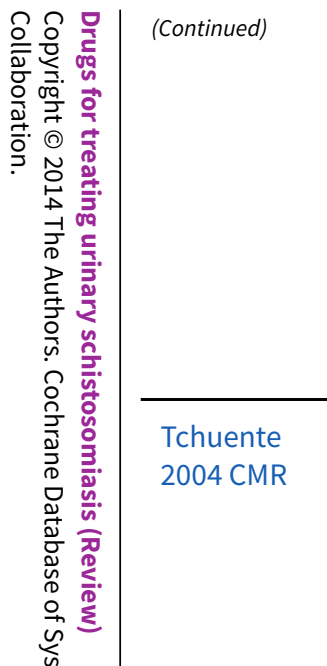 }} & & \multicolumn{5}{|c|}{$N=30$} & \multicolumn{4}{|l|}{$N=32$} & \multirow{3}{*}{ 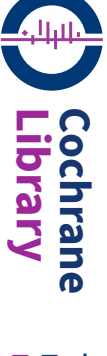 } \\
\hline & & & heavy & 500 to 1999 & $\begin{array}{l}907.6 \\
N=38\end{array}$ & 1.8 & 99.8 & - & - & - & & \\
\hline & & & very heavy & $>2000$ & $\begin{array}{l}3433.3 \\
N=8\end{array}$ & 2.2 & 99.93 & - & - & - & & \\
\hline & & $\begin{array}{l}3 \\
\text { months }\end{array}$ & light & $<50$ & $\begin{array}{l}8.22 \\
N=183\end{array}$ & 0.86 & $89.53 \%$ & - & - & - & - & 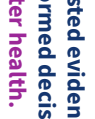 \\
\hline & & & heavy & $>50$ & $\begin{array}{l}115.59 \\
N=63\end{array}$ & 4.11 & $96.4 \%$ & - & - & - & - & \\
\hline 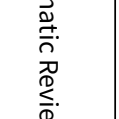 & $\begin{array}{l}\text { Taylor } 1988 \\
\text { ZWE }\end{array}$ & $\begin{array}{l}3 \\
\text { months }\end{array}$ & light & $<50$ & $\begin{array}{l}15.1 \\
N=\text { n.r. }\end{array}$ & 0.4 & 97.35 & 15.7 & 19.8 & $\begin{array}{l}26.1 \text { in- } \\
\text { crease }\end{array}$ & - & \\
\hline $\begin{array}{l}0 \\
\bar{c} \\
\bar{c} \\
\overline{\bar{v}} \\
\overline{0} \\
\overline{0}\end{array}$ & & & heavy & $>100$ & $\begin{array}{l}204.7 \\
N=\text { n.r. }\end{array}$ & 2.0 & 99 & 191.9 & 94.7 & 50.65 & - & \\
\hline 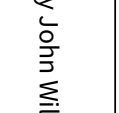 & $\begin{array}{l}\text { Pugh } 1983 \\
\text { MWI }\end{array}$ & $\begin{array}{l}6 \\
\text { months }\end{array}$ & light & 20 to 124 & $\begin{array}{l}51.7 \\
N=21\end{array}$ & 2.3 & 95.5 & - & - & - & - & \\
\hline $\begin{array}{l}\infty \\
\tilde{0} \\
0 \\
\tilde{n} \\
-\end{array}$ & & & moderate & 125 to 499 & $\begin{array}{l}234.7 \\
N=30\end{array}$ & 2.0 & 99.14 & - & - & - & - & \\
\hline $\begin{array}{l}\stackrel{ }{2} \\
\text { O } \\
\frac{D}{D} \\
\stackrel{0}{\#}\end{array}$ & & & heavy & 500 to 1999 & $\begin{array}{l}907.6 \\
N=38\end{array}$ & 2.6 & 99.7 & - & - & - & - & 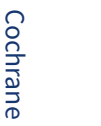 \\
\hline 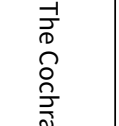 & & & very heavy & $>2000$ & $\begin{array}{l}3433.3 \\
N=8\end{array}$ & 2.8 & 99.9 & - & - & - & - & 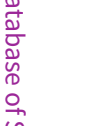 \\
\hline & $\begin{array}{l}\text { Taylor } 1988 \\
\text { ZWE }\end{array}$ & $\begin{array}{l}6 \\
\text { months }\end{array}$ & light & $<50$ & $\begin{array}{l}15.1 \\
N=n . r .\end{array}$ & 0.2 & 98.67 & 15.7 & 11.7 & 25.5 & - & 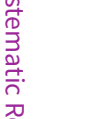 \\
\hline$\stackrel{\leftrightarrow}{\omega}$ & & & heavy & $>100$ & 204.7 & 0.6 & 99.7 & 191.9 & 75.5 & 60.6 & - & $\sum_{n=1}^{\bar{n}}$ \\
\hline
\end{tabular}




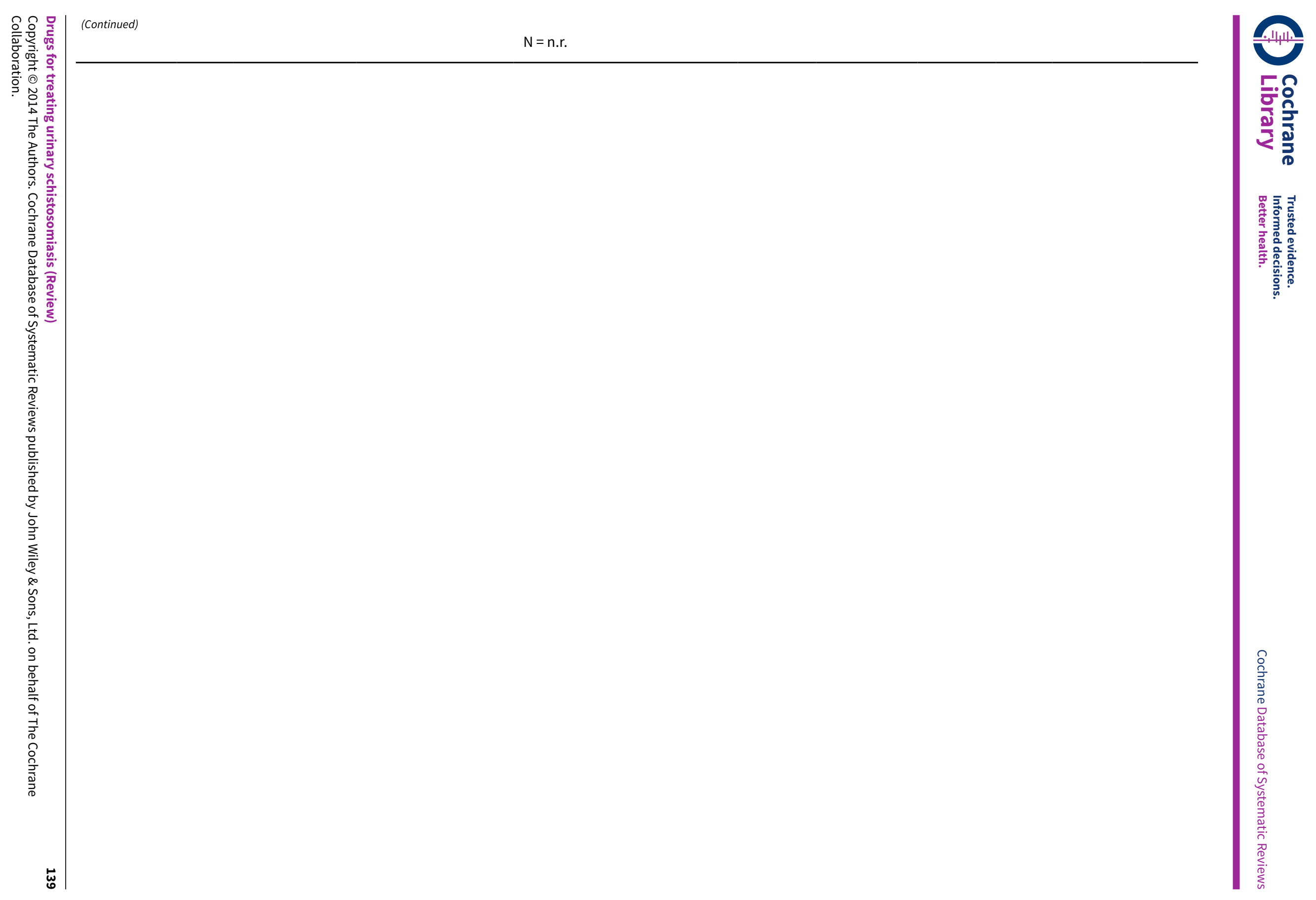


1Stratum I: light infections < 50 eggs $/ 10 \mathrm{~mL}$, praziquantel $(\mathrm{N}=77)$, placebo $(\mathrm{N}=90)$. "Pretreatment light infections exhibited better cure rates for $S$. haematobium than pretreatment heavy infections". Praziquantel $(N=77)$, placebo $(N=90)$.

2Baseline imbalance in terms of intensity of infection "In accordance with local ethical guidelines the placebo group consisted only of children with light (20 to $124 \mathrm{ova} / 10 \mathrm{~mL}$ or moderate (125 to $4999 \mathrm{ova} / 10 \mathrm{~mL}$ ) infections before treatment."

Praziquantel $40 \mathrm{mg} / \mathrm{kg}$ single dose versus $20 \mathrm{mg} / \mathrm{kg}$ single dose: \% egg reduction 


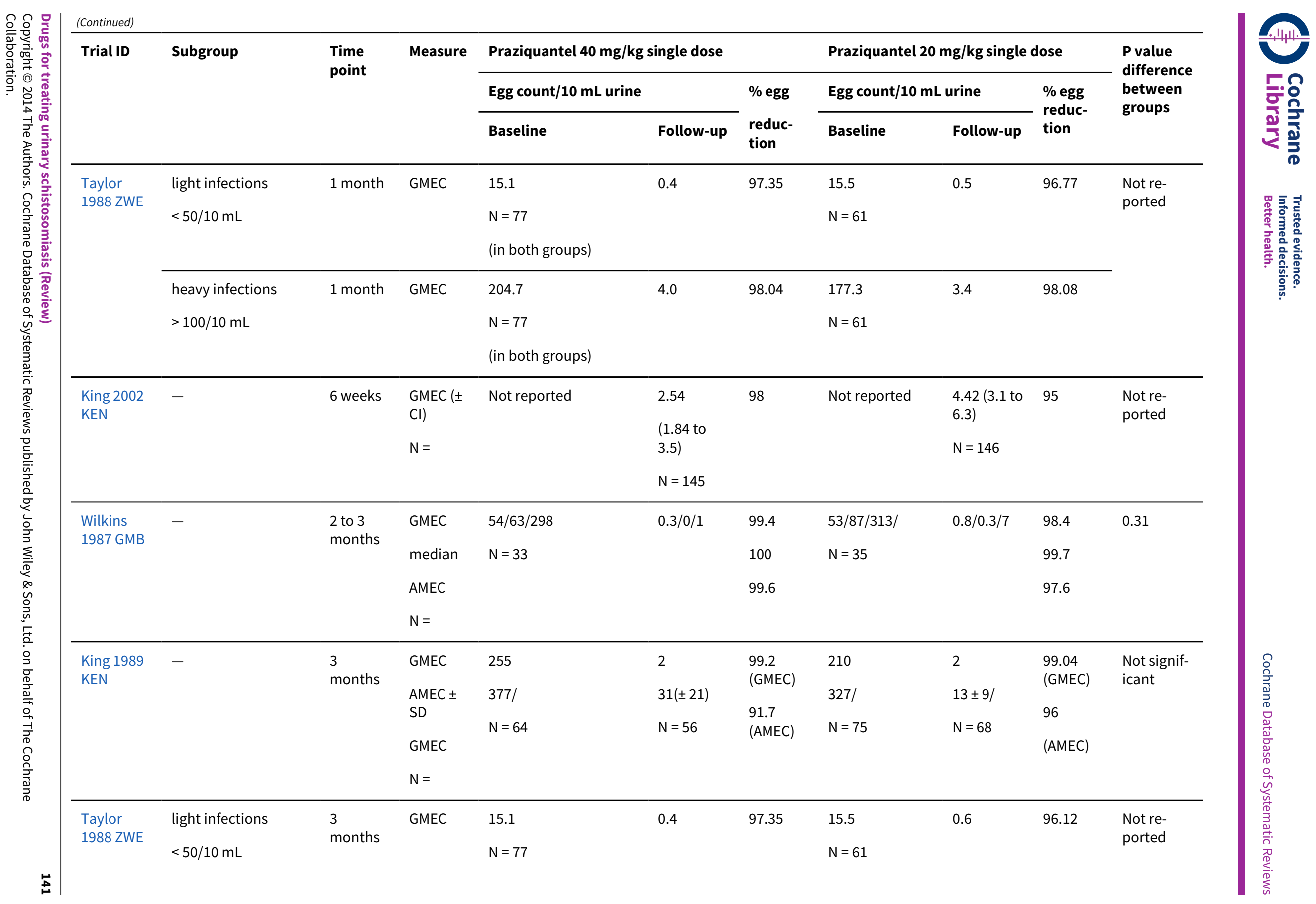




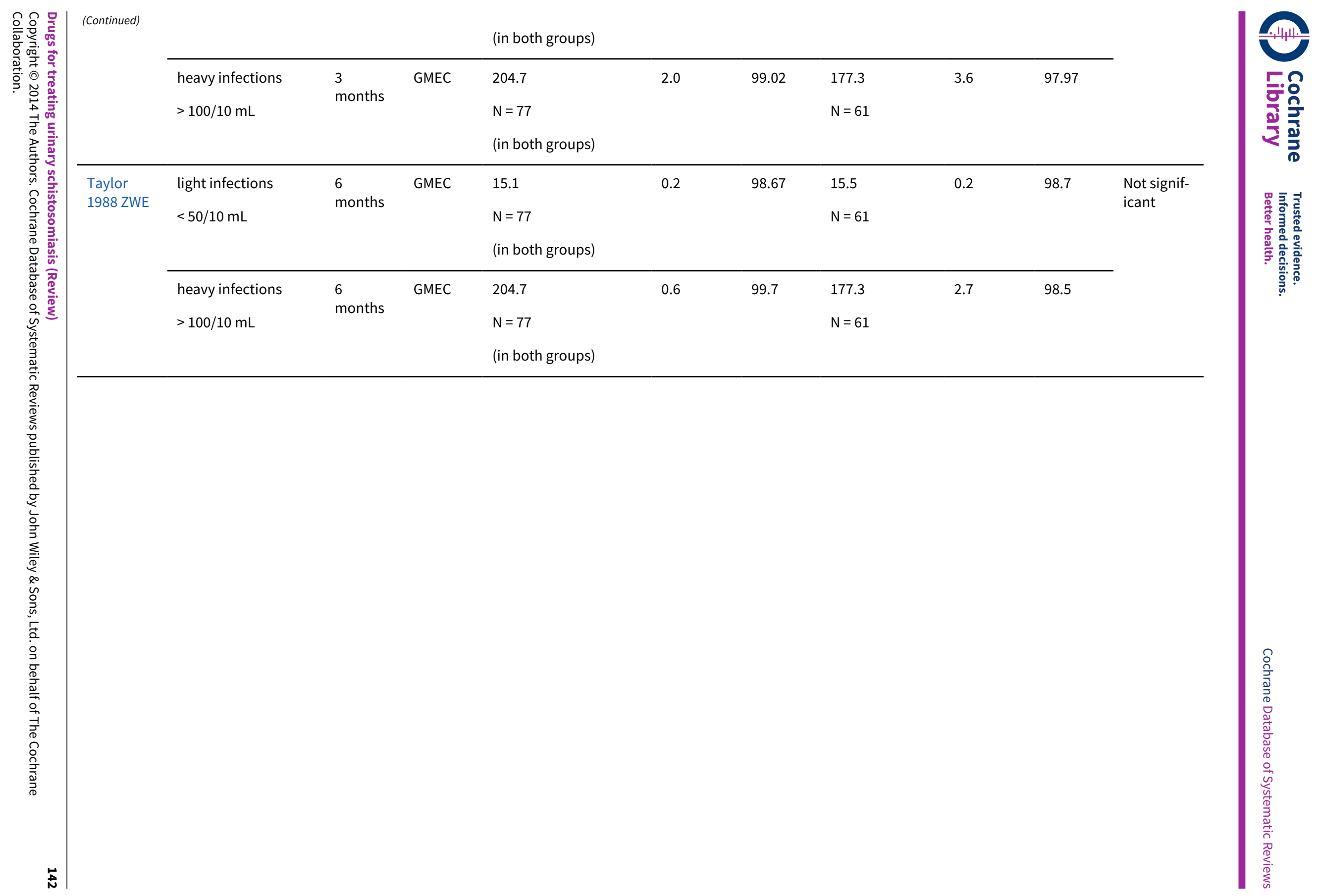


Praziquantel $40 \mathrm{mg} / \mathrm{kg}$ single dose versus $10 \mathrm{mg} / \mathrm{kg}$ single dose: $\%$ egg reduction 


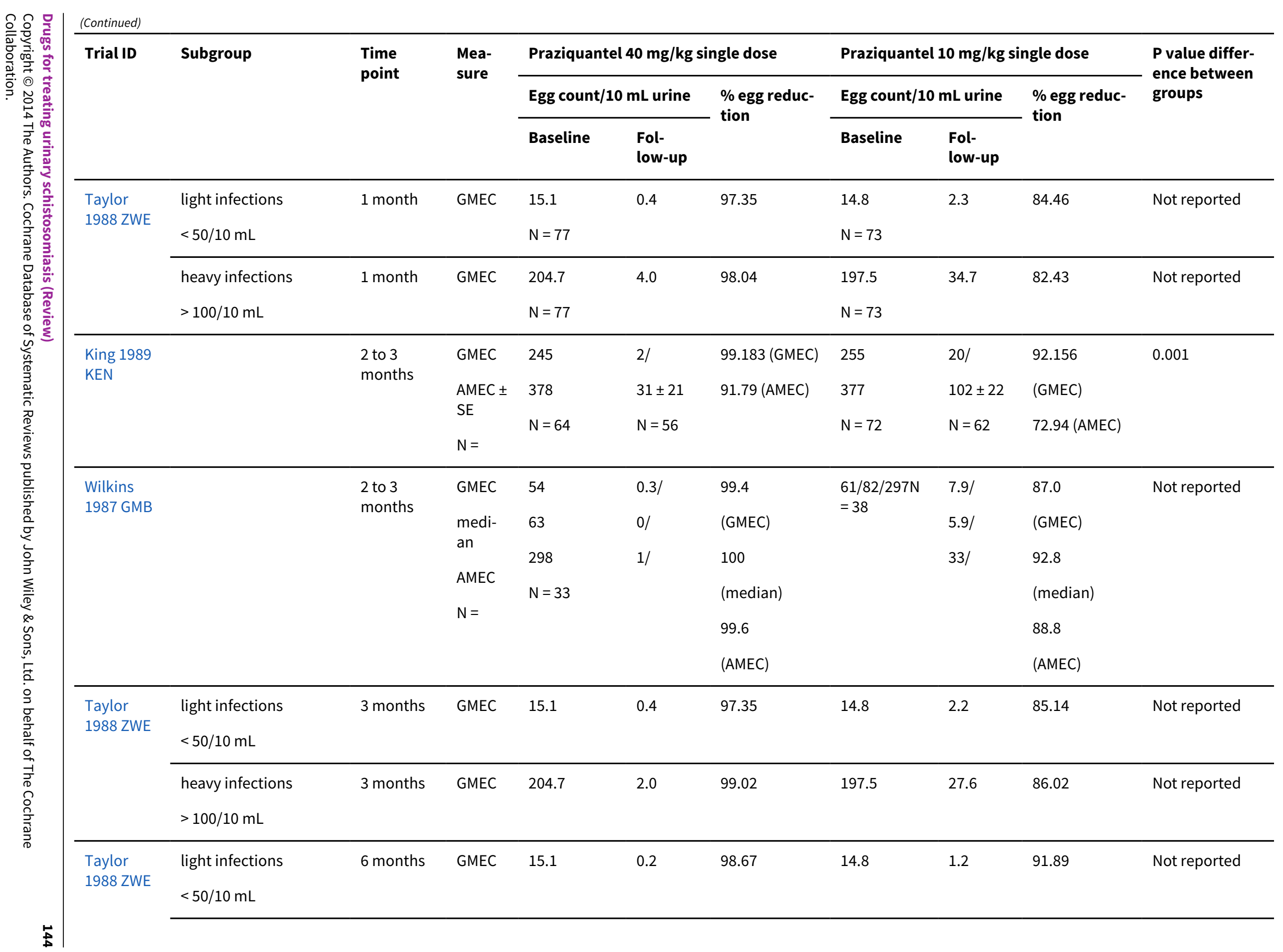




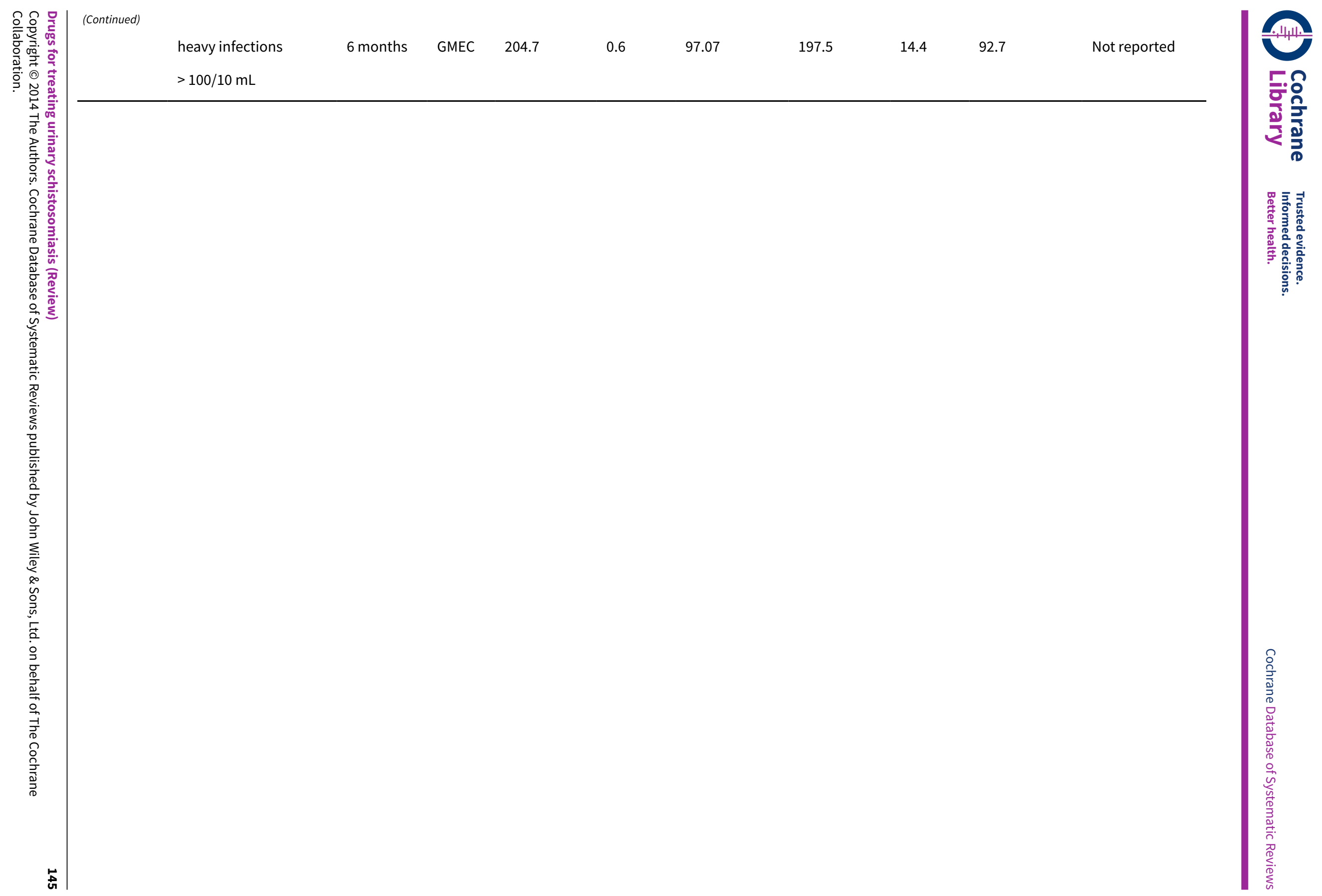


Praziquantel $40 \mathrm{mg} / \mathrm{kg}$ single dose versus split dose: $\%$ egg reduction 


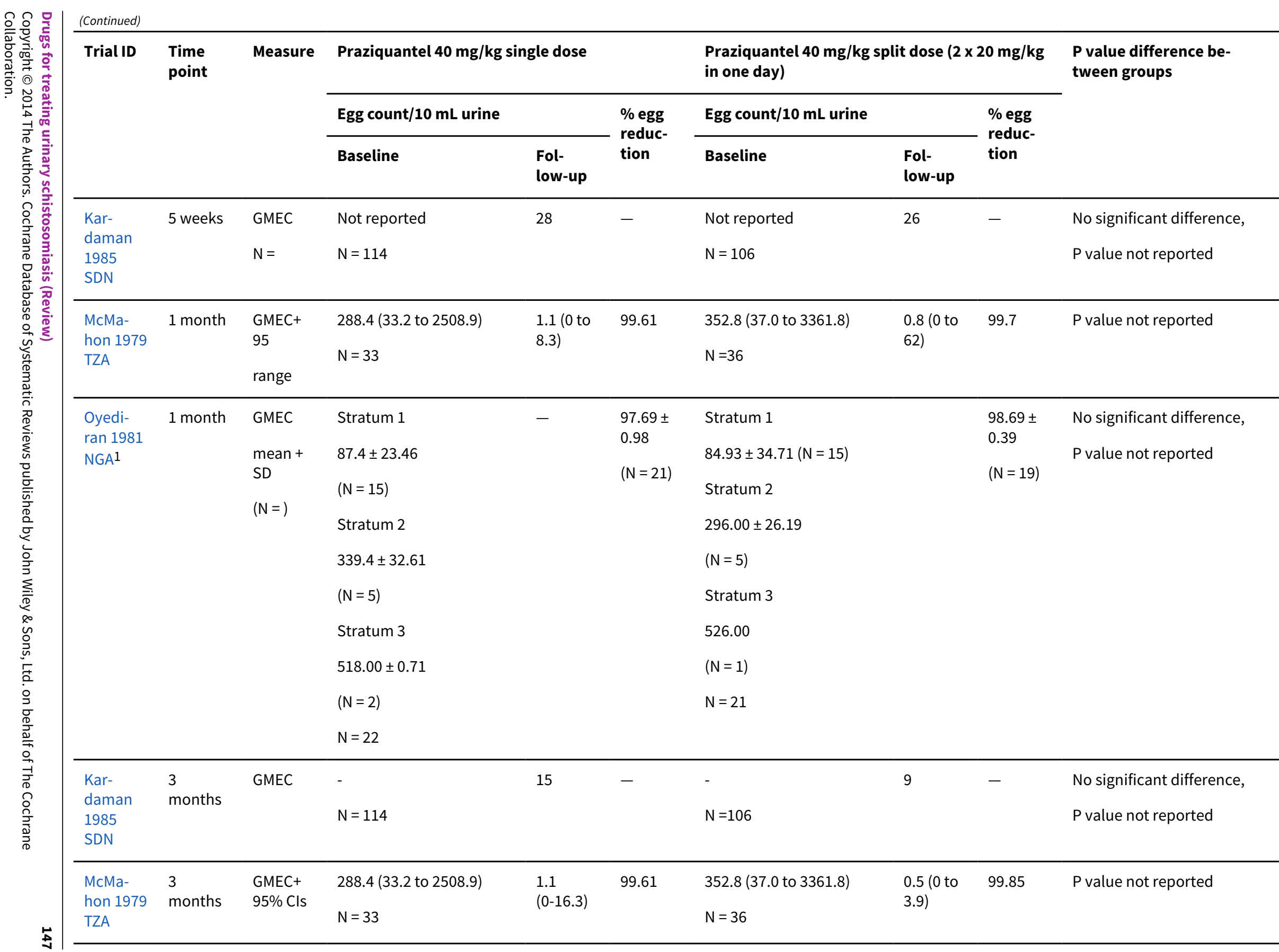




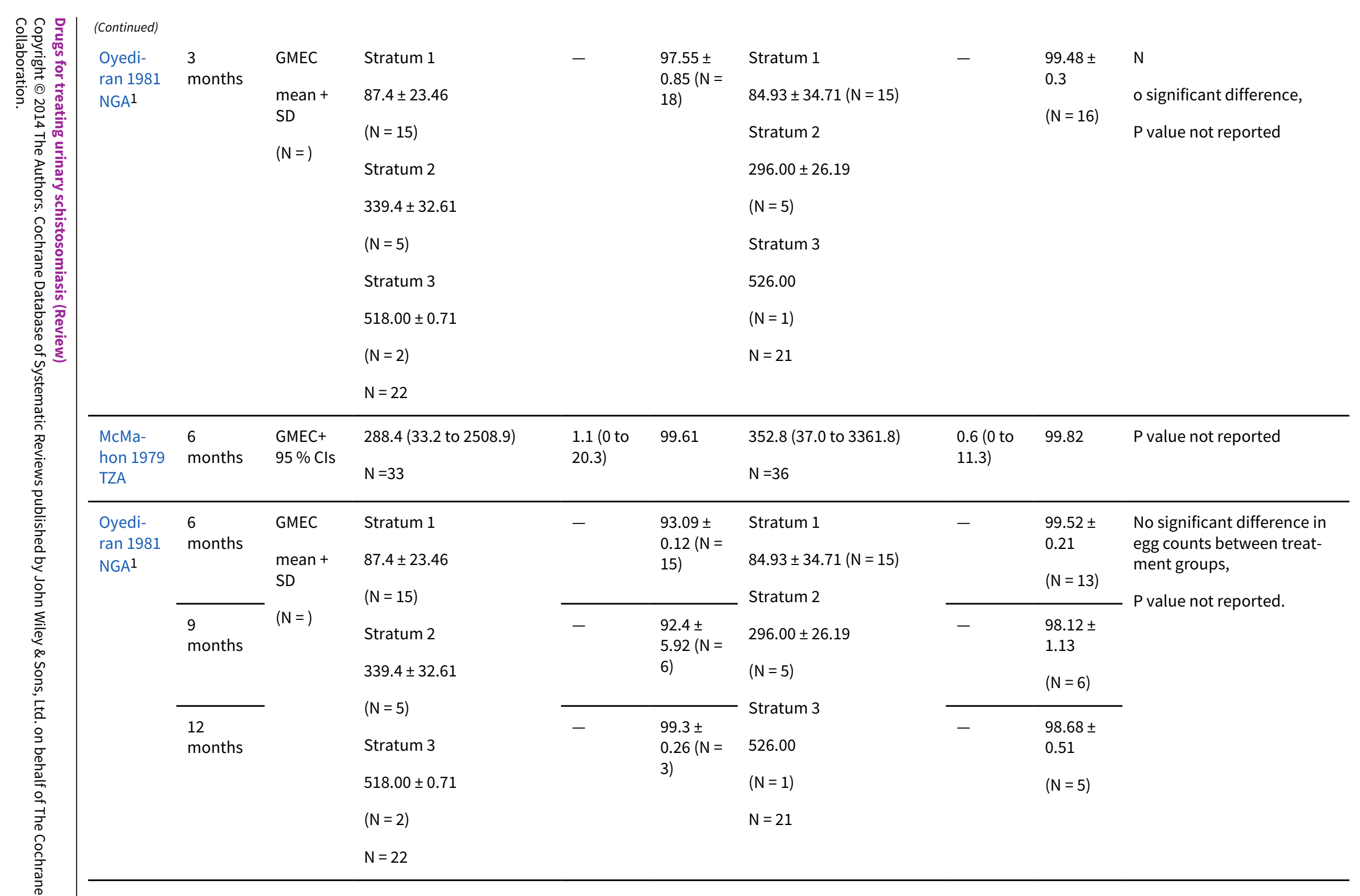


1GMEC/10 mL urine, Stratum 1: 60 to $250 \mathrm{GMEC} / 10 \mathrm{~mL}$ urine; Stratum 2: 251 to $500 \mathrm{GMEC} / 10 \mathrm{~mL}$; Stratum $3>500 \mathrm{GMEC} / 10 \mathrm{~mL}$.

Praziquantel $40 \mathrm{mg} / \mathrm{kg}$ single dose versus praziquantel $2 \times 40 \mathrm{mg} / \mathrm{kg}$ or praziquantel $3 \times 40 \mathrm{mg} / \mathrm{kg}$ given three weeks apart: \% egg reduction 


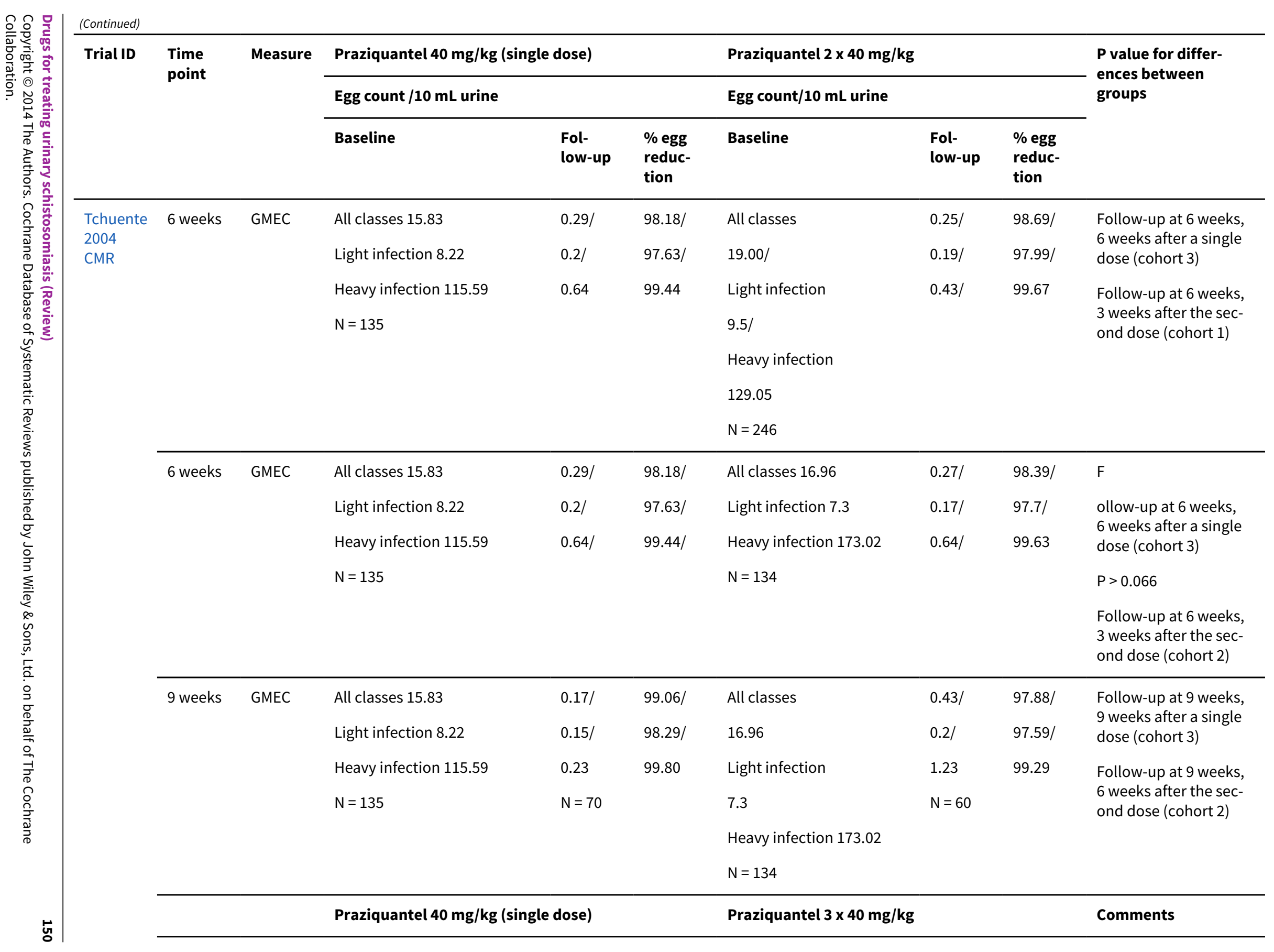




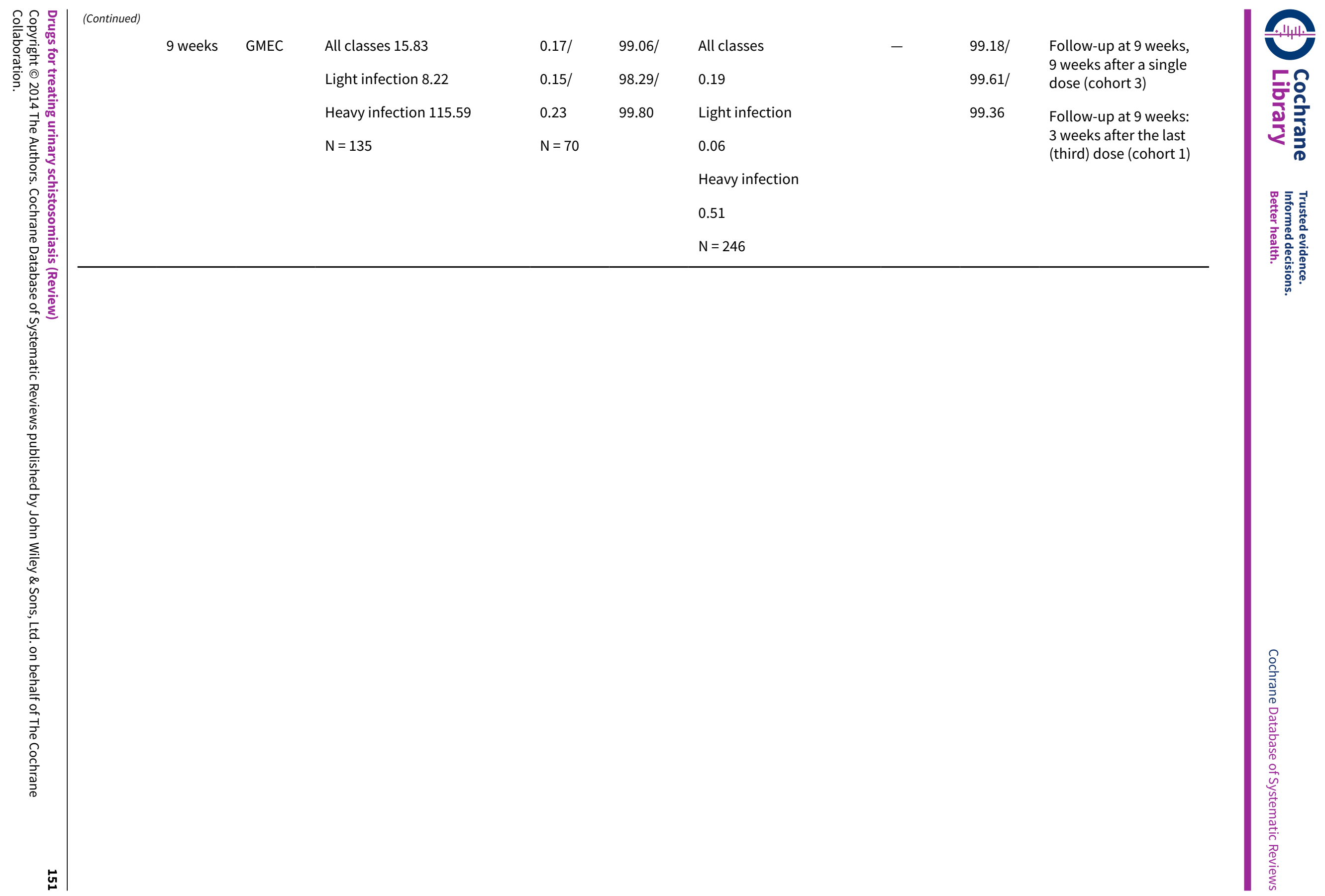


Praziquantel $40 \mathrm{mg} / \mathrm{kg}$ single dose $\times 2$, interval three weeks: one arm received praziquantel single at baseline, one arm received a second dose at three weeks, one arm received the second dose at three weeks and a third dose at six weeks. Follow-up for all groups at six weeks and nine weeks.

Strata: light infection $<50 / 10 \mathrm{~mL}$, heavy infection $>50 / 10 \mathrm{~mL}$.

Metrifonate $10 \mathrm{mg} / \mathrm{kg}$ single dose versus placebo: \% egg reduction 


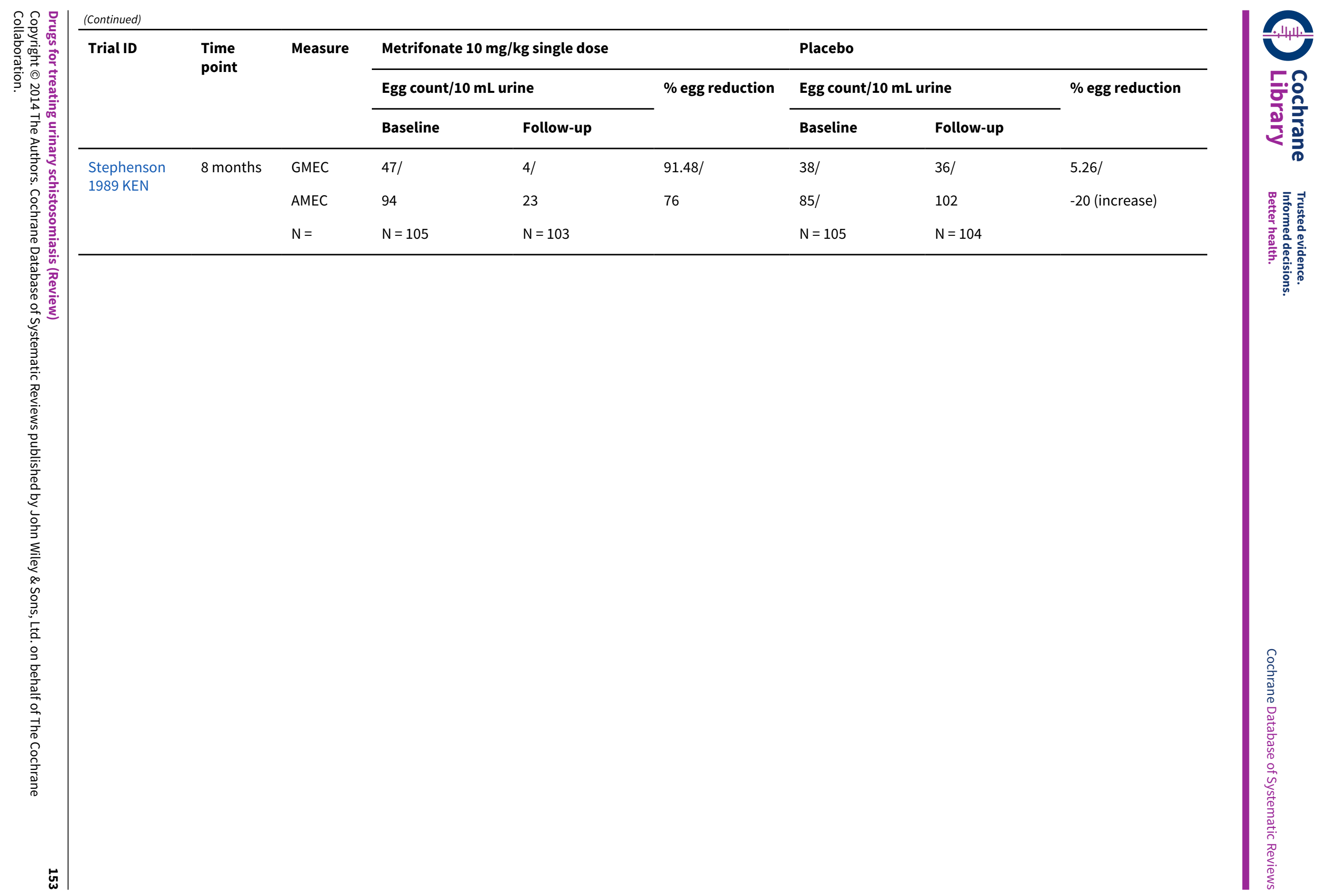


Metrifonate $2 \times 10$ and $3 \times 10 \mathrm{mg} / \mathrm{kg}$ given two weeks apart versus $10 \mathrm{mg} / \mathrm{kg}$ single dose: \% egg reduction 


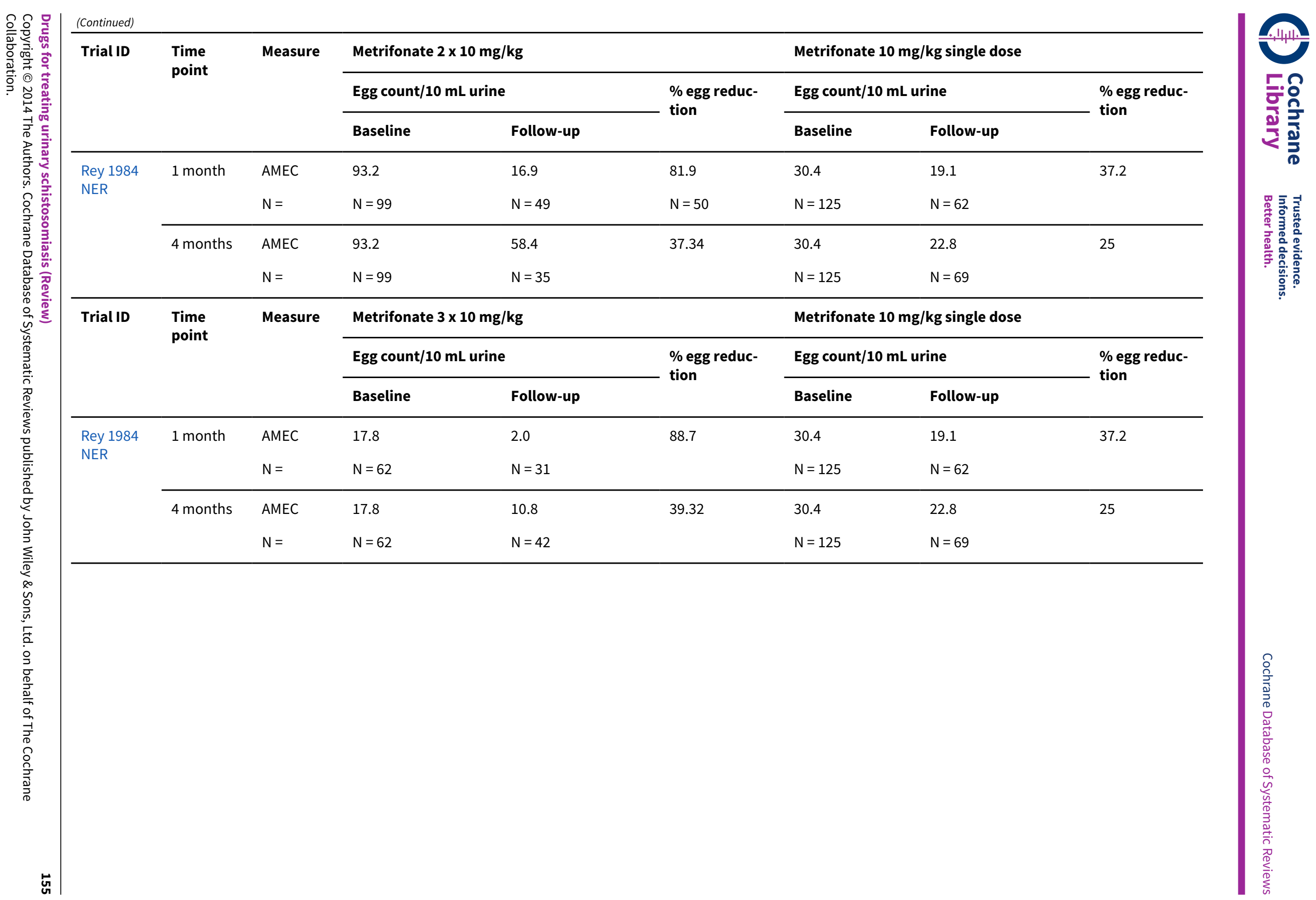


Metrifonate 3 doses two weeks apart: $7.5 \mathrm{mg} / \mathrm{kg}$ versus $5 \mathrm{mg} / \mathrm{kg}$ : \% egg reduction 


\begin{tabular}{|c|c|c|c|c|c|c|c|c|c|}
\hline \multicolumn{10}{|l|}{ ○ } \\
\hline \multirow[t]{3}{*}{ Trial ID } & \multirow{3}{*}{$\begin{array}{l}\text { Time } \\
\text { point }\end{array}$} & \multirow[t]{3}{*}{ Measure } & \multicolumn{3}{|c|}{ Metrifonate $7.5 \mathrm{mg} / \mathrm{kg} \mathrm{x} 3$} & \multicolumn{3}{|c|}{ Metrifonate $5 \mathrm{mg} / \mathrm{kg} \times 3$} & \multirow{3}{*}{$\begin{array}{l}P \text { value difference } \\
\text { between groups }\end{array}$} \\
\hline & & & \multicolumn{2}{|c|}{ Egg count/10 $\mathrm{mL}$ urine } & \multirow{2}{*}{$\begin{array}{l}\% \text { egg reduc- } \\
\text { tion }\end{array}$} & \multicolumn{2}{|c|}{ Egg count/10 $\mathrm{mL}$ urine } & \multirow{2}{*}{$\begin{array}{l}\text { \% egg re- } \\
\text { duction }\end{array}$} & \\
\hline & & & Baseline & $\begin{array}{l}\text { Fol- } \\
\text { low-up }\end{array}$ & & Baseline & $\begin{array}{l}\text { Fol- } \\
\text { low-up }\end{array}$ & & \\
\hline \multirow{3}{*}{$\begin{array}{l}\text { Abden } \\
\text { Abdi } \\
1989 \\
\text { SOM }\end{array}$} & 1 month & \multirow{4}{*}{$\begin{array}{l}\text { Egg count/10 mL } \\
\text { urine mean } \\
\text { (SD) } \\
\text { \% egg reduction } \\
\text { mean (SD) }\end{array}$} & $1010(1550)$ & - & $97(5)$ & $997(1700)$ & - & $96(6)$ & \multirow{4}{*}{$\begin{array}{l}P>0.7 \\
\text { (difference in egg } \\
\text { counts at } 1 \text { and } 6 \\
\text { months) }\end{array}$} \\
\hline & 2 months & & $1010(1550)$ & - & $97(6)$ & $997(1700)$ & - & $96(7)$ & \\
\hline & 3 months & & $1010(1550)$ & - & $95(8)$ & $997(1700)$ & - & $94(8)$ & \\
\hline$\stackrel{0}{0} \stackrel{0}{0}$ & 6 months & & $1010(1550)$ & - & $93(11)$ & $997(1700)$ & - & $92(11)$ & \\
\hline
\end{tabular}


$1_{\mathrm{N}}=101$ for both groups together

Praziquantel $40 \mathrm{mg} / \mathrm{kg}$ single dose versus metrifonate $10 \mathrm{mg} / \mathrm{kg}$ single dose: $\%$ egg reduction 


\begin{tabular}{|c|c|c|c|c|c|c|c|c|c|c|}
\hline \multirow{7}{*}{ 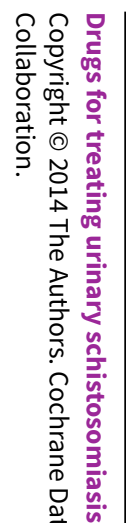 } & \multicolumn{10}{|l|}{ (Continued) } \\
\hline & \multirow[t]{3}{*}{ Trial ID } & \multirow{3}{*}{$\begin{array}{l}\text { Time } \\
\text { point }\end{array}$} & \multirow[t]{3}{*}{ Measure } & \multicolumn{3}{|c|}{ Praziquantel $40 \mathrm{mg} / \mathrm{kg}$ single dose } & \multicolumn{3}{|c|}{ Metrifonate $10 \mathrm{mg} / \mathrm{kg}$ single dose } & \multirow{3}{*}{$\begin{array}{l}\text { P value differ- } \\
\text { ences betweer } \\
\text { groups }\end{array}$} \\
\hline & & & & \multicolumn{2}{|c|}{ Egg count $/ 10 \mathrm{~mL}$ urine } & \multirow{2}{*}{$\begin{array}{l}\text { \% egg re- } \\
\text { duction }\end{array}$} & \multicolumn{2}{|c|}{ Egg count $/ 10 \mathrm{~mL}$ urine } & \multirow{2}{*}{$\begin{array}{l}\text { \% egg re- } \\
\text { duction }\end{array}$} & \\
\hline & & & & Baseline & Follow-up & & Baseline & Follow-up & & \\
\hline & Stephen- & 8 & AMEC & $112 /$ & $1 /$ & 99 & $94 /$ & $23 /$ & 76 & Significant \\
\hline & KEN & & GMEC & 57 & 0.2 & & 47 & 4 & & $P<0.0001$ \\
\hline & & & & $N=105$ & & & $N=103$ & & & \\
\hline
\end{tabular}


Praziquantel $40 \mathrm{mg} / \mathrm{kg}$ single dose versus metrifonate $2 \times 10 \mathrm{mg} / \mathrm{kg}$ given two weeks apart: \% egg reduction 


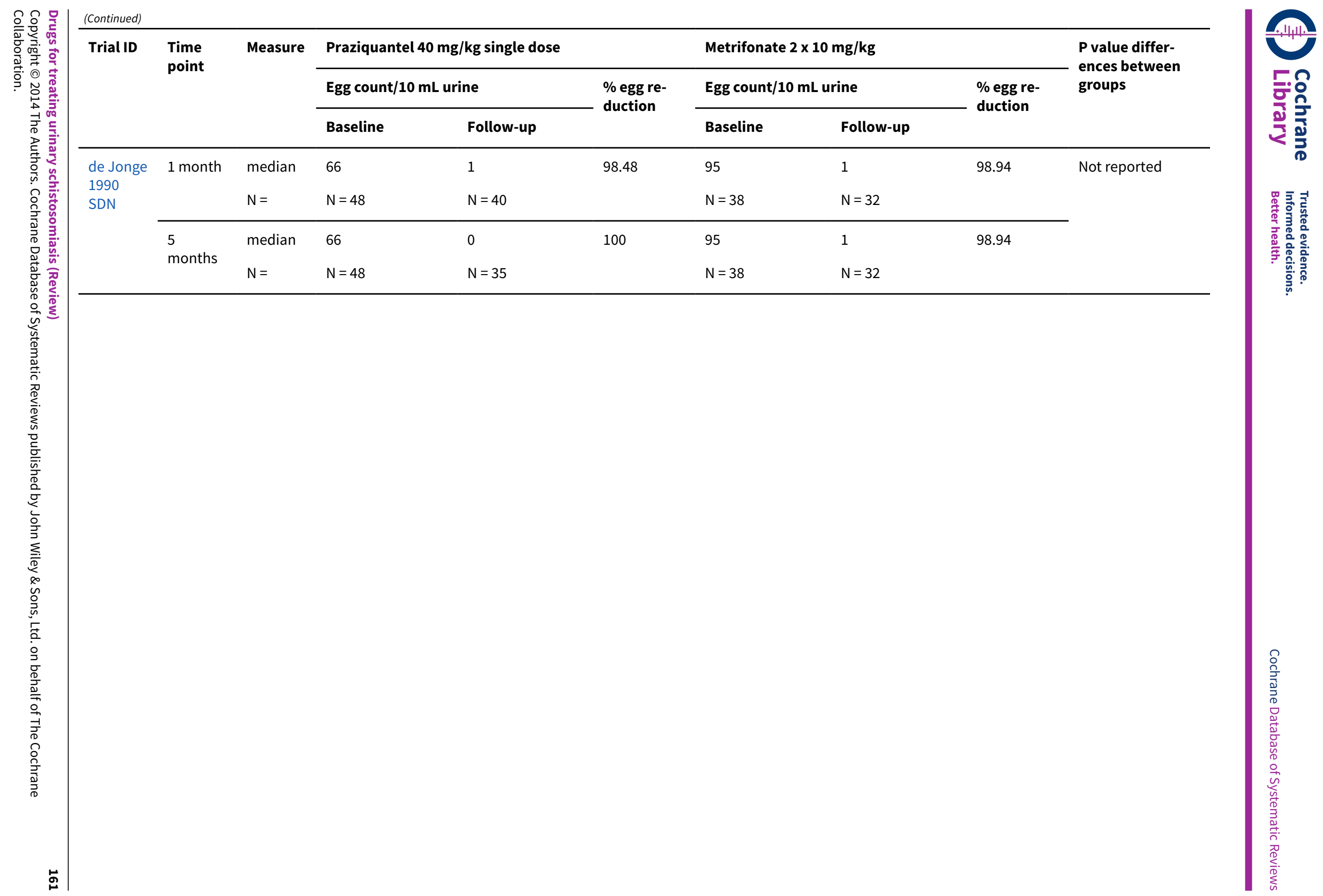


Praziquantel $30 \mathrm{mg} / \mathrm{kg}$ single dose versus metrifonate $3 \times 10 \mathrm{mg} / \mathrm{kg}$ given two weeks apart: \% egg reduction 


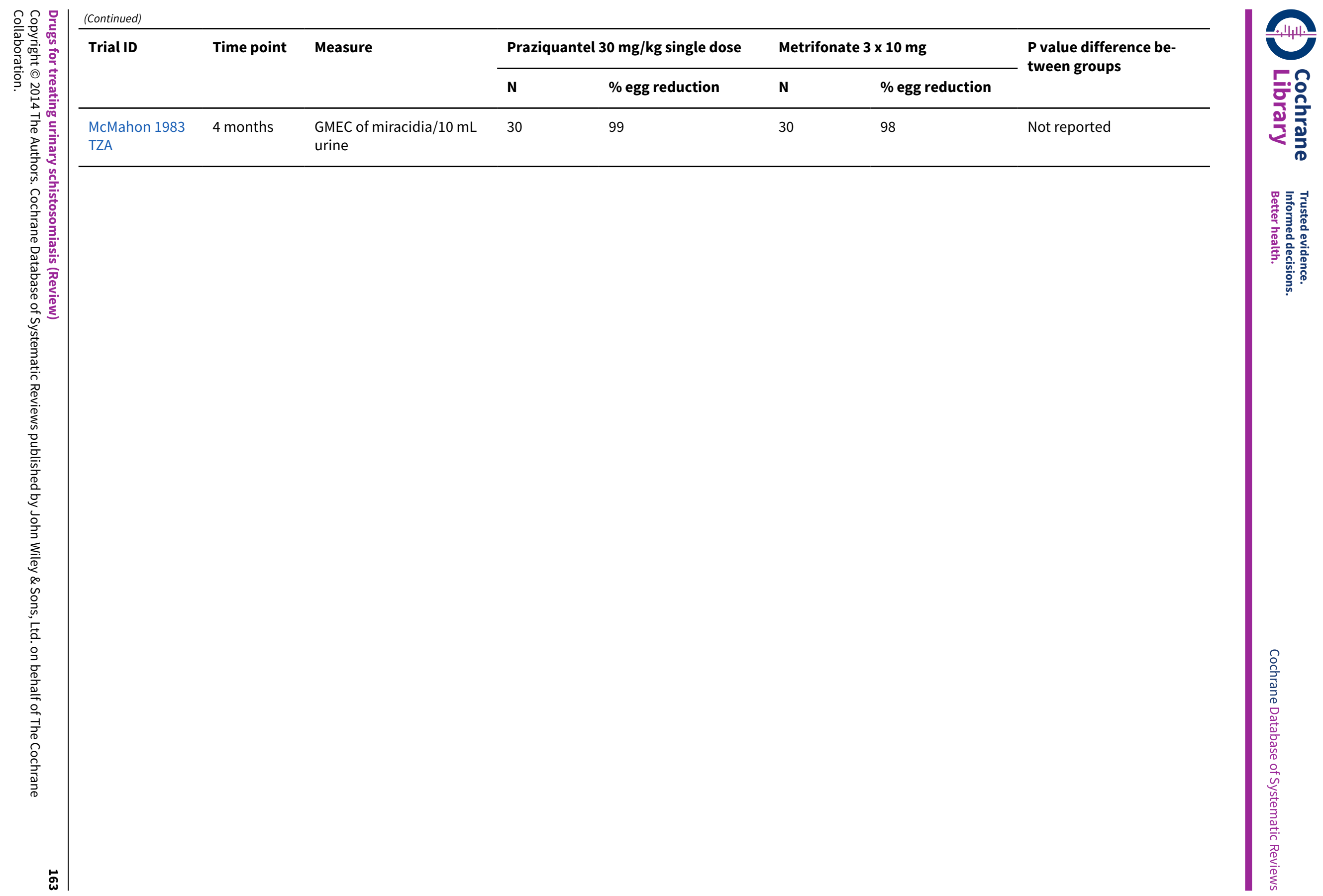


Praziquantel $40 \mathrm{mg} / \mathrm{kg}$ 1x/year versus metrifonate $10 \mathrm{mg} / \mathrm{kg}$ 3x/year: \% egg reduction 


\begin{tabular}{|c|c|c|c|c|c|c|c|c|c|}
\hline \multirow{4}{*}{ 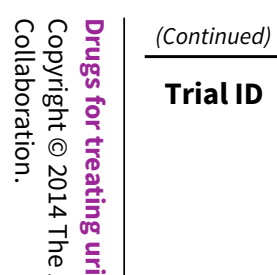 } & \multirow{4}{*}{$\begin{array}{l}\text { Time } \\
\text { point }\end{array}$} & \multirow{4}{*}{ Measure } & & & & & & & \\
\hline & & & \multicolumn{3}{|c|}{ Praziquantel 40 mg/kg 1x/year } & \multicolumn{3}{|c|}{ Metrifonate $10 \mathrm{mg} / \mathrm{kg} \mathrm{3x/year}$} & \multirow{3}{*}{$\begin{array}{l}\text { P value differ- } \\
\text { ence between } \\
\text { groups }\end{array}$} \\
\hline & & & \multicolumn{2}{|c|}{ Egg count $/ 10 \mathrm{~mL}$ urine } & \multirow{2}{*}{$\begin{array}{l}\% \text { egg reduc- } \\
\text { tion }\end{array}$} & \multicolumn{2}{|c|}{ Egg count $/ 10 \mathrm{~mL}$ urine } & \multirow{2}{*}{$\begin{array}{l}\% \text { egg reduc- } \\
\text { tion }\end{array}$} & \\
\hline & & & Baseline & Follow-up & & Baseline & Follow-up & & \\
\hline King & \multirow{9}{*}{$\begin{array}{l}12 \\
\text { months }\end{array}$} & \multirow{9}{*}{$\begin{array}{l}\text { AMEC ( } \pm \\
\text { SD) } \\
\text { GMEC }\end{array}$} & Light & $6 \pm 2$ & 81.81 & Light & $4 \pm 3$ & 87.87 & \multirow[t]{9}{*}{ Not significant } \\
\hline KEN1 & & & 33 & & & 33 & - & & \\
\hline 沀 & & & 19 & & & 19 & & & \\
\hline 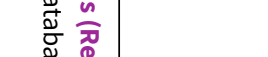 & & & Moderate & $3 \pm 2$ & 98.44 & Moderate & $5 \pm 2$ & 97.4 & \\
\hline $\begin{array}{ll}0 & 0 \\
0 & 0 \\
0 & 0 \\
0 & 0\end{array}$ & & & 193 & & & 193 & - & & \\
\hline 㲾 & & & 86 & & & 86 & & & \\
\hline $\bar{n}$ & & & Heavy & $8 \pm 4$ & 98.65 & Heavy & $9 \pm 3$ & 89.49 & \\
\hline$\sum_{n=1}^{\infty}$ & & & 597 & & & 597 & - & & \\
\hline$\underline{\underline{\underline{\sigma}}}$ & & & 581 & & & 581 & & & \\
\hline
\end{tabular}


1Baseline data reported for both treatment groups together.

Praziquantel $40 \mathrm{mg} / \mathrm{kg}$ single dose versus praziquantel $10 \mathrm{mg} / \mathrm{kg}$ and metrifonate $10 \mathrm{mg} / \mathrm{kg}$ : \% egg reduction 


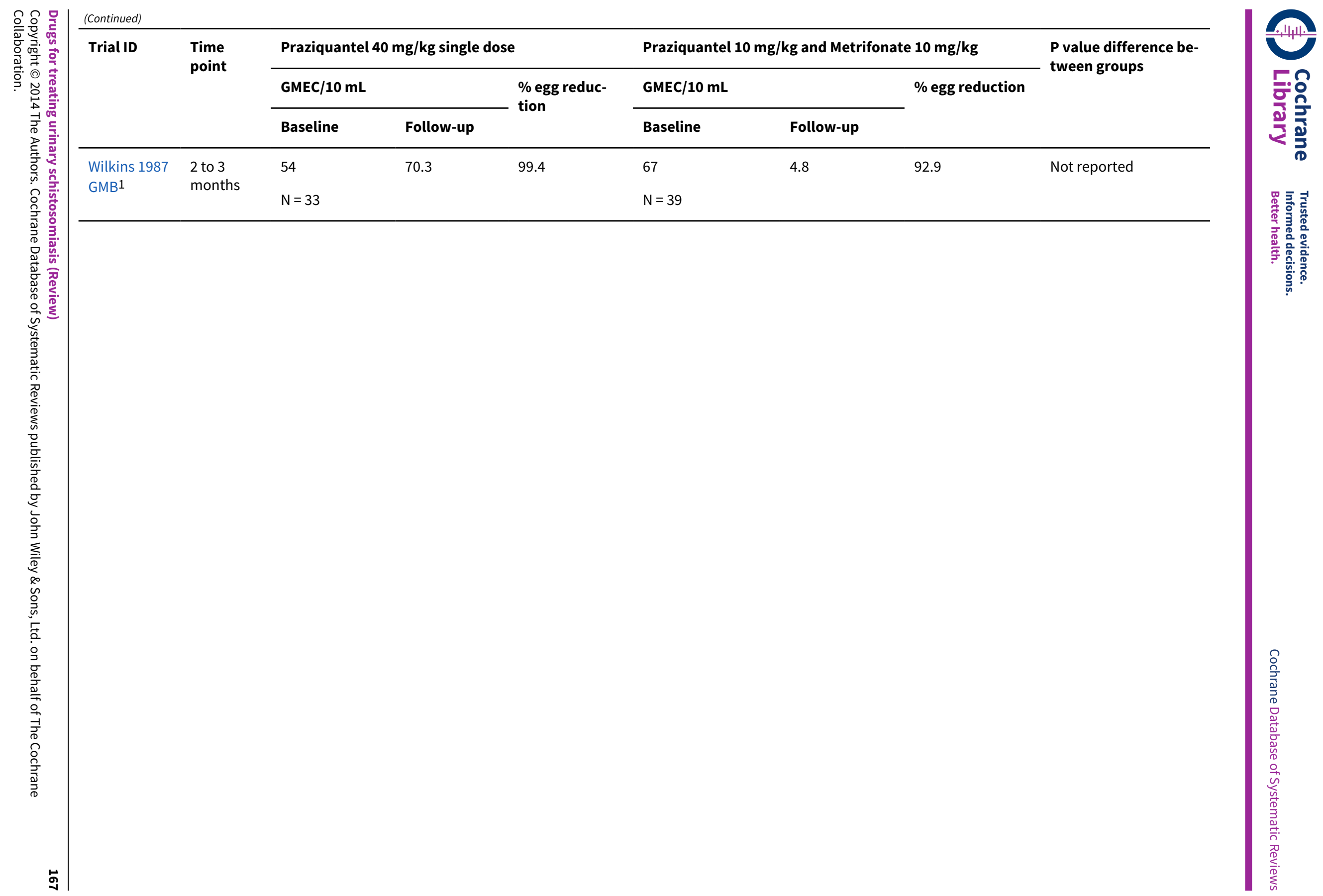


${ }_{1}$ AMEC and median also reported.

Praziquantel versus artesunate: $\%$ egg reduction 


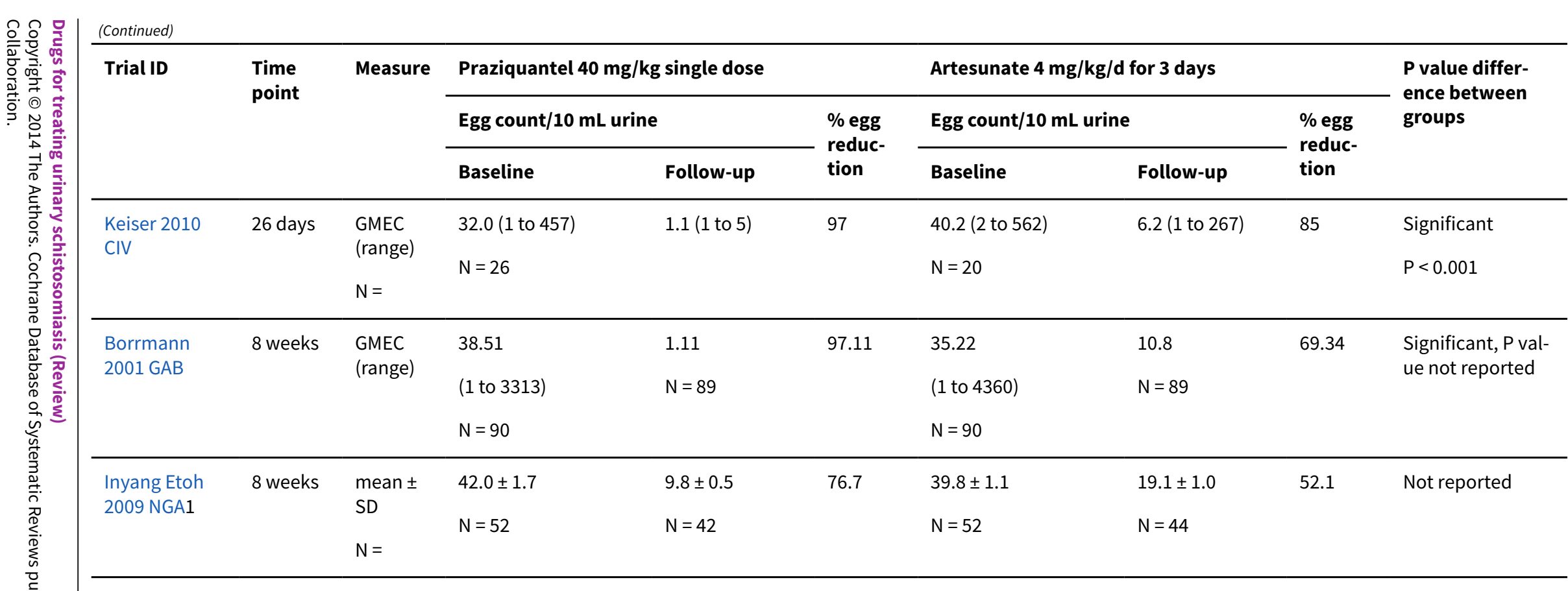


1Treatment group: Praziquantel 40 mg/kg without placebo. Inyang Etoh 2009 NGA also reports a second treatment group (Praziquantel $40 \mathrm{mg} / \mathrm{kg}$ with placebo), data not shown.

\section{Mefloquine versus placebo: $\%$ egg reduction}




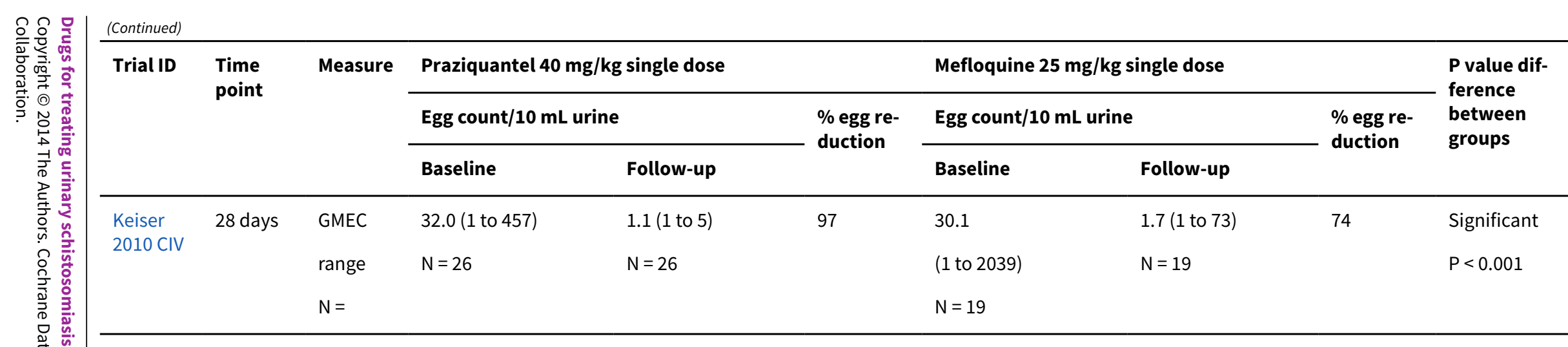


Praziquantel versus mefloquine: \% egg reduction 


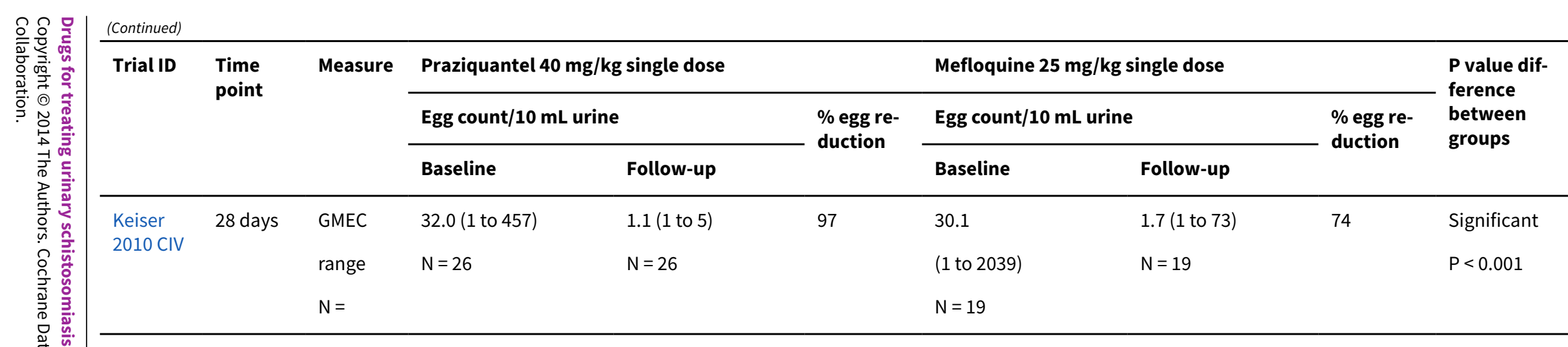


Praziquantel versus mefloquine and artesunate: $\%$ egg reduction 


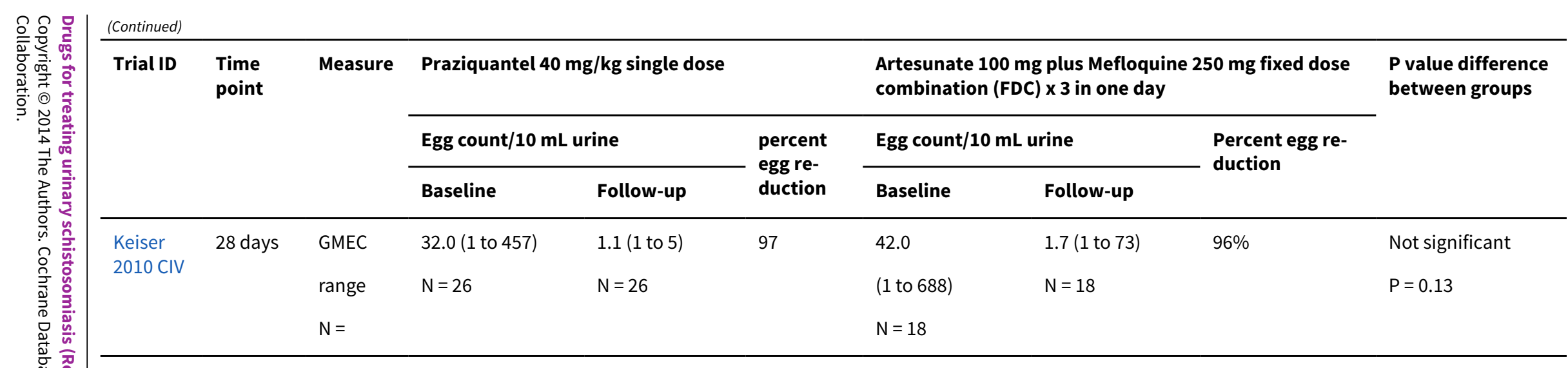


Appendix 3. Appendix: Additional tables for haematuria and proteinuria

Praziquantel $40 \mathrm{mg} / \mathrm{kg}$ single dose versus placebo: haematuria and proteinuria 


\begin{tabular}{|c|c|c|c|c|c|c|c|c|}
\hline \multicolumn{9}{|l|}{ (Continued) } \\
\hline \multirow{2}{*}{$\begin{array}{l}\text { Out- Trial ID } \\
\text { come }\end{array}$} & \multirow{2}{*}{$\begin{array}{l}\text { Time } \\
\text { point }\end{array}$} & \multirow[t]{2}{*}{ Measure } & \multicolumn{3}{|c|}{ Praziquantel 40 mg/kg single dose } & \multicolumn{2}{|l|}{ Placebo } & \multirow{2}{*}{$\begin{array}{l}\text { P value differ- } \\
\text { ence between } \\
\text { groups } \\
\text { ge }\end{array}$} \\
\hline & & & Baseline & Follow-up & $\begin{array}{l}\text { Mean } \\
\% \\
\text { change }\end{array}$ & Baseline & Follow-up & \\
\hline $\begin{array}{l}\text { Haema-Jonge } 1990 \\
\text { turiaSDN }\end{array}$ & $\begin{array}{l}1 \\
\text { month }\end{array}$ & $\begin{array}{l}\text { median erythro- } \\
\text { cytes/mykrol ( } 95 \% \\
\mathrm{Cl})\end{array}$ & $\begin{array}{l}159(34 \text { to } 627) N= \\
56\end{array}$ & $\begin{array}{l}1(0 \text { to } 2) \\
N=56\end{array}$ & -99.37 & $\begin{array}{l}290(54 \text { to } 1224) \\
N=26\end{array}$ & 323 (51 to 864$)$ & +11.37 Not reported \\
\hline $\begin{array}{l}\text { Borrmann } 2001 \\
\text { GAB1 }\end{array}$ & $\begin{array}{l}8 \\
\text { weeks }\end{array}$ & $\begin{array}{l}\text { erythrocytes/mL } \\
(95 \% \mathrm{Cl})\end{array}$ & $\begin{array}{l}N R \\
N=89\end{array}$ & $\begin{array}{l}-110^{1} \\
(-137 \text { to }-84)\end{array}$ & - & $\begin{array}{l}N R \\
N=30\end{array}$ & $\begin{array}{l}-391 \\
(-86 \text { to }-8)\end{array}$ & $\begin{array}{l}\text { Significant } \\
P<0.001\end{array}$ \\
\hline $\begin{array}{l}\text { Inyang Etoh } \\
2009 \text { NGA }\end{array}$ & $\begin{array}{l}8 \\
\text { weeks }\end{array}$ & $\begin{array}{l}\text { units unclear mean } \\
( \pm S D)\end{array}$ & $47.6( \pm 2.0) \mathrm{N}=52$ & $\begin{array}{l}7.6( \pm 0.9) \\
N=42\end{array}$ & -84.033 & $\begin{array}{l}38.0( \pm 1.6) \\
N=52\end{array}$ & $\begin{array}{l}59.6( \pm 2.2) \mathrm{N}= \\
44\end{array}$ & $+56.84 \mathrm{P}<0.001$ \\
\hline $\begin{array}{l}\text { Pro- de Jonge } 1990 \\
\text { tein-SDN } \\
\text { uria }\end{array}$ & $\begin{array}{l}1 \\
\text { month }\end{array}$ & $\begin{array}{l}\text { median, g/L } \\
(95 \% \mathrm{Cl})\end{array}$ & $\begin{array}{l}0.42(0.22 \text { to } 0.62) \mathrm{N} \\
=56\end{array}$ & 0.09 (0.05 to 0.12$)$ & -78 & $\begin{array}{l}0.24 \text { ( } 0.09 \text { to } \\
0.59 \text { ) } \\
\mathrm{N}=26\end{array}$ & $\begin{array}{l}0.32 \text { ( } 0.14 \text { to } \\
0.35)\end{array}$ & +33.3 Not reported \\
\hline $\begin{array}{l}\text { Inyang Etoh } \\
2009 \text { NGA } 2\end{array}$ & $\begin{array}{l}8 \\
\text { weeks }\end{array}$ & $\begin{array}{l}\text { mean }( \pm \text { SD) } \\
\text { units unclear }\end{array}$ & $160.2( \pm 5.2) \mathrm{N}=52$ & $\begin{array}{l}24.8 \pm 1.9 \\
N=42\end{array}$ & -84 & $\begin{array}{l}185.2 \pm 5.0 \\
N=52\end{array}$ & $\begin{array}{l}213.9 \pm 5.3 N= \\
44\end{array}$ & $+15.49 P<0.001$ \\
\hline
\end{tabular}




\section{Footnotes}

1Mean change from baseline in erythrocytes $/ \mathrm{mL}$ urine $(95 \% \mathrm{Cl})$.

2Data shown here are for the treatment group praziquantel $40 \mathrm{mg} / \mathrm{kg}$ without placebo. Inyang Etoh 2009 NGA also reports a treatment group for praziquantel with placebo, (data not shown).

Praziquantel 40 mg/kg single dose versus Praziquantel $2 \times 40$ mg/kg: haematuria 


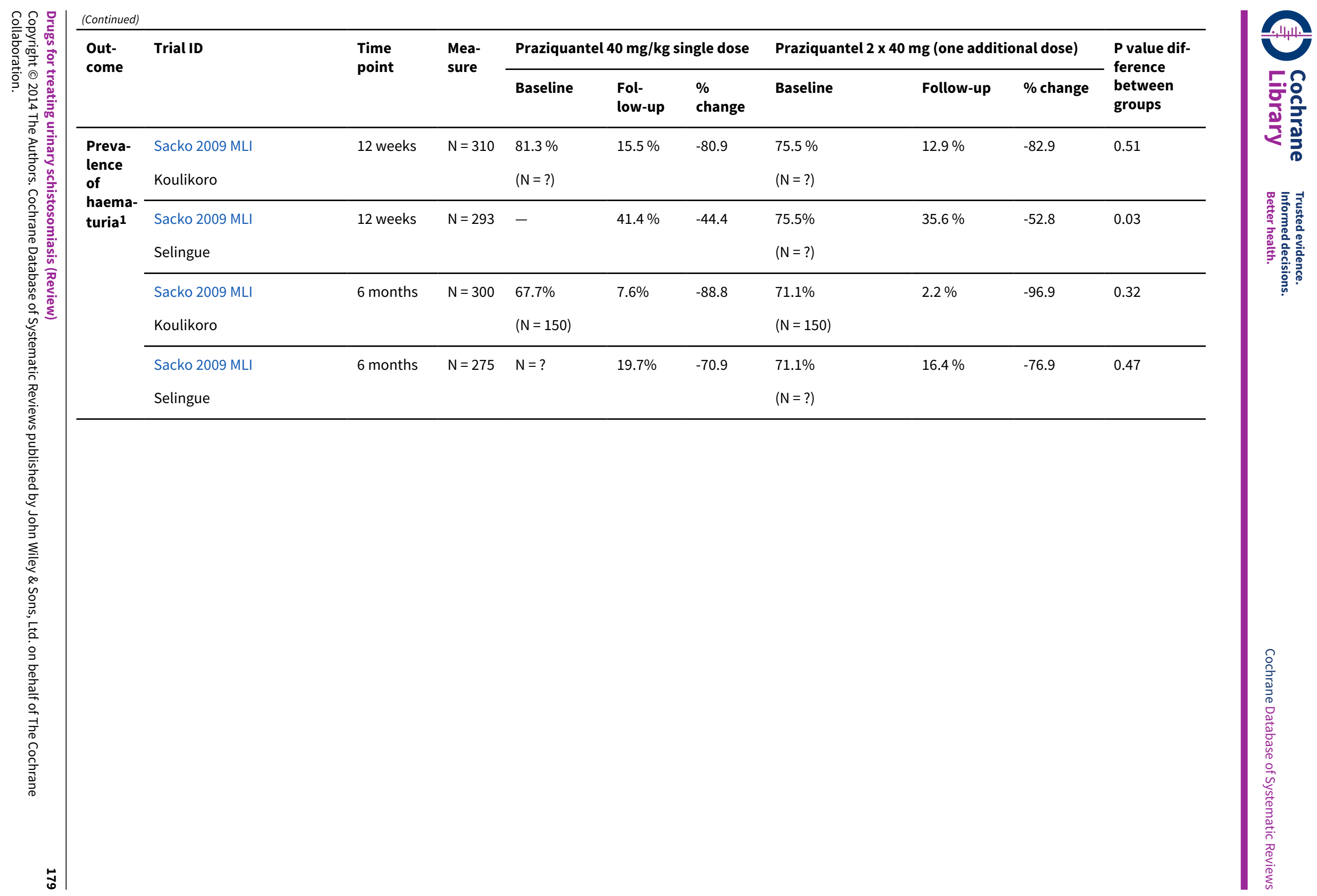


1Microhaematuria as diagnosed by dipstick (Haemastix)

Praziquantel $40 \mathrm{mg} / \mathrm{kg}$ single dose versus Metrifonate $20 \mathrm{mg} / \mathrm{kg}$ given as split dose: haematuria and proteinuria 


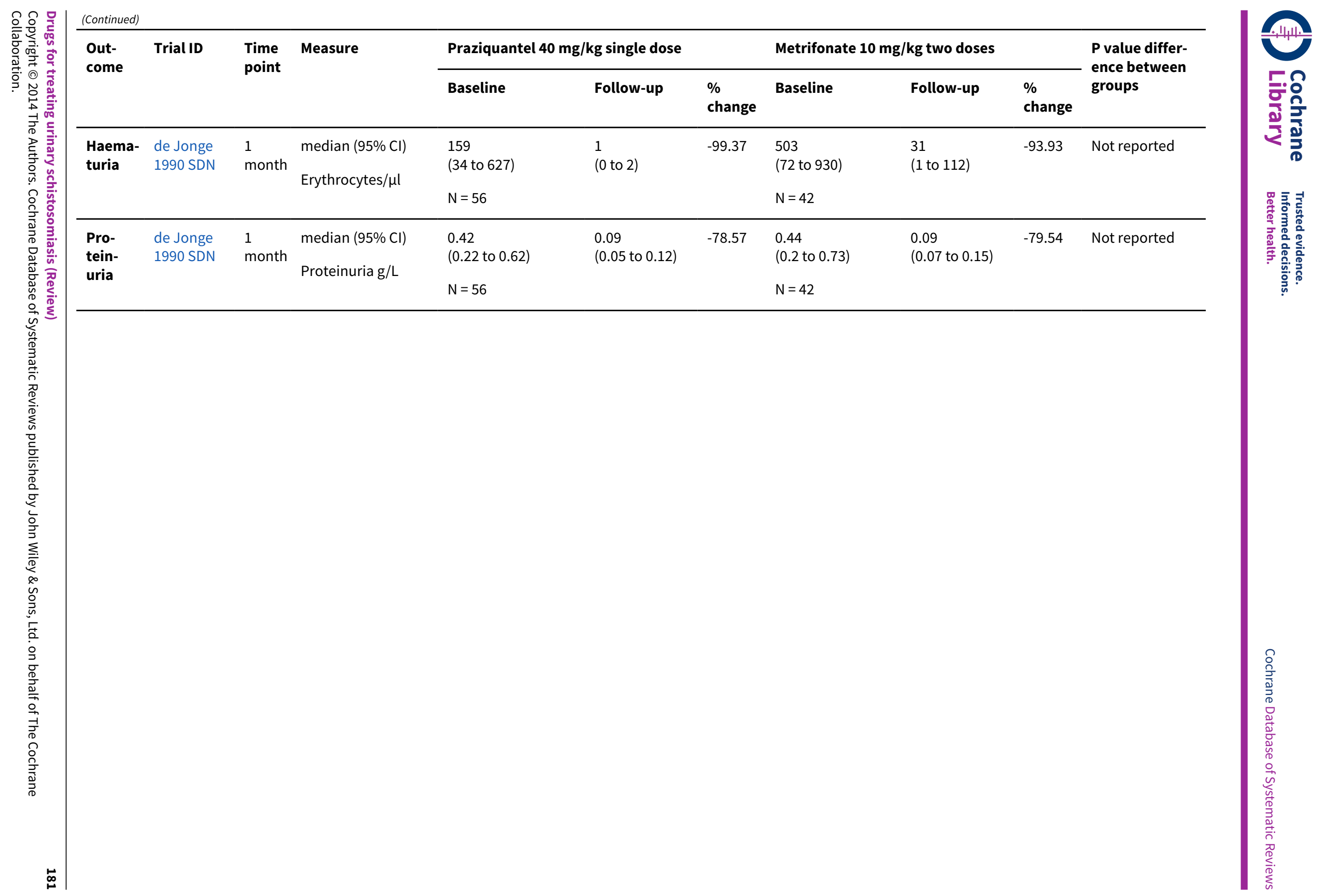


ARS versus placebo: haematuria and proteinuria 


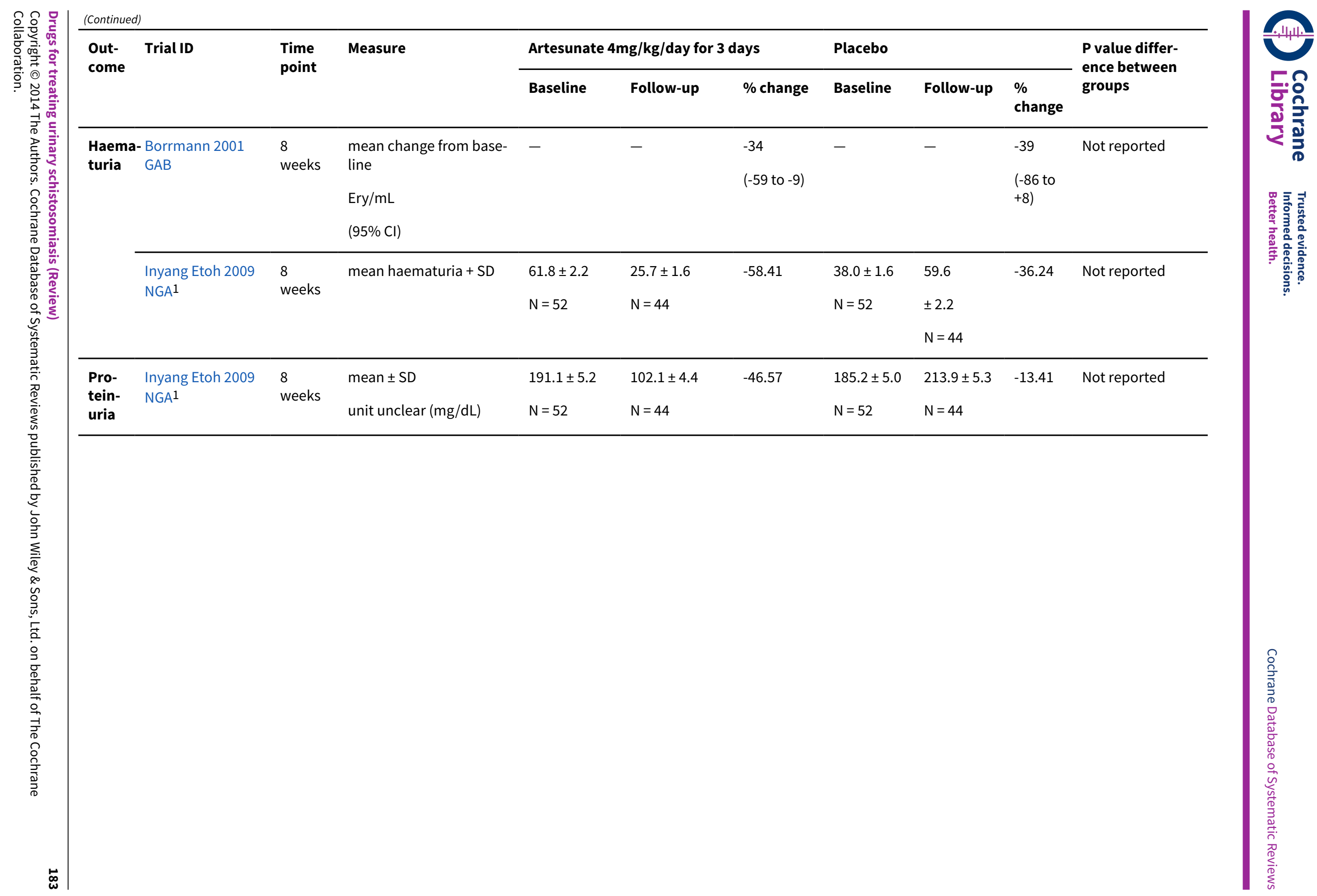




\section{Footnotes}

1Treatment group: Praziquantel $40 \mathrm{mg} / \mathrm{kg}$ without placebo. Inyang Etoh 2009 NGA also reports a second treatment group (Praziquantel $40 \mathrm{mg} / \mathrm{kg}$ with placebo), data not shown.

\section{Praziquantel versus ARS: haematuria and proteinuria}




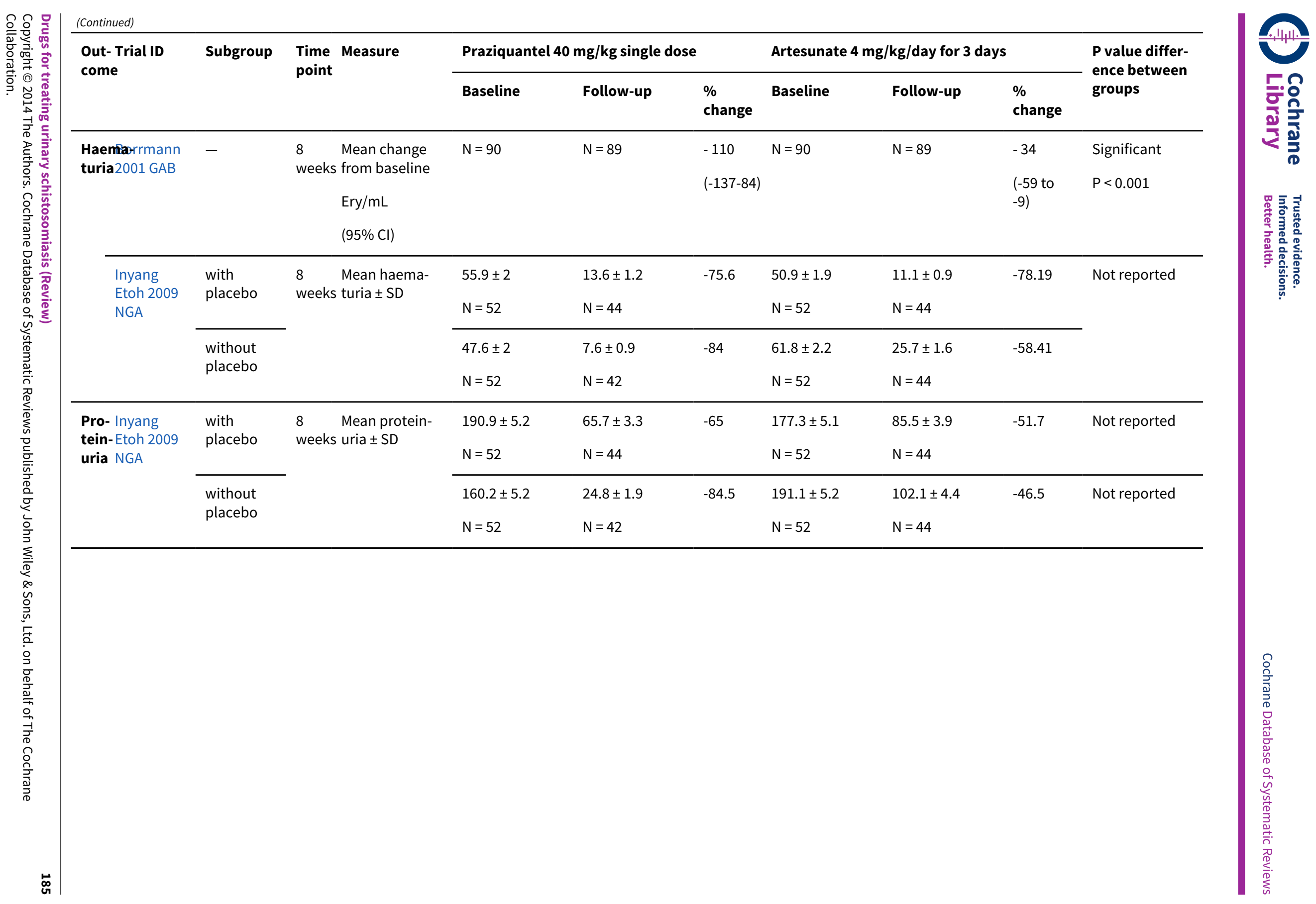


Praziquantel versus Praziquantel and ARS: haematuria and proteinuria 


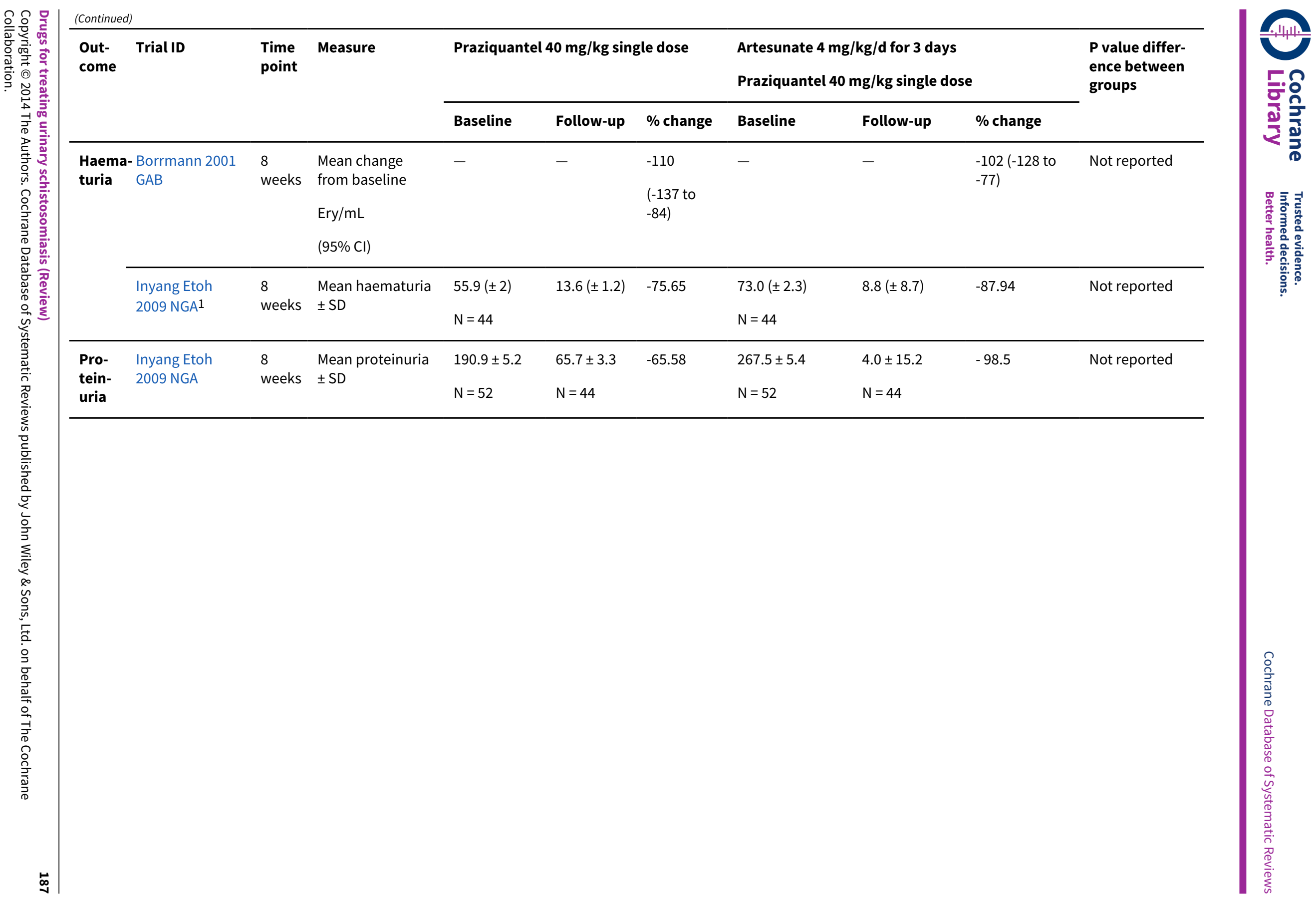


1Treatment group: Praziquantel 40 mg/kg with placebo. Inyang Etoh 2009 NGA also reports a second treatment group (Praziquantel 40 $\mathrm{mg} / \mathrm{kg}$ without placebo), data not shown.

Appendix 4. Appendix: Additional tables for growth outcomes

Praziquantel $40 \mathrm{mg} / \mathrm{kg}$ single dose versus placebo: growth outcomes

Drugs for treating urinary schistosomiasis (Review) 


\begin{tabular}{|c|c|c|c|c|c|c|c|c|c|c|}
\hline \multirow{3}{*}{\multicolumn{2}{|c|}{ 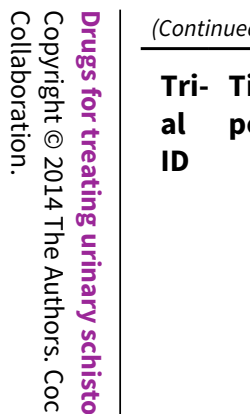 }} & \multirow{3}{*}{$\begin{array}{l}\text { Tim } \\
\text { point }\end{array}$} & & & & & & & & \\
\hline & & & \multicolumn{4}{|c|}{ Praziquantel $40 \mathrm{mg} / \mathrm{kg}$ single dose } & \multicolumn{3}{|l|}{ Placebo } & \multirow{2}{*}{$\begin{array}{l}\text { P value difference be- } \\
\text { tween praziquantel } 40 \\
\mathrm{mg} / \mathrm{kg} \text { and placebo after } \\
\text { treatment }\end{array}$} \\
\hline & & & Baseline & Follow-up & $\begin{array}{l}\text { growth } \\
\text { greater } \\
\text { than } \\
\text { placebo }\end{array}$ & $\begin{array}{l}\text { P value } \\
\text { differ- } \\
\text { ence be- } \\
\text { fore and } \\
\text { after } \\
\text { treat- } \\
\text { ment }\end{array}$ & Baseline & Follow-up & $\begin{array}{l}\text { Differ- } \\
\text { ence be- } \\
\text { fore and } \\
\text { after } \\
\text { treatment }\end{array}$ & \\
\hline 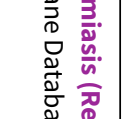 & \multicolumn{2}{|c|}{$\begin{array}{l}\text { Stepl5en Harvard step test score } \\
\text { son weeks } \\
1989 \text { mean } \pm \text { SEM }\end{array}$} & $76 \pm+-1.41$ & $81.2 \pm 1$ & $\begin{array}{l}6.8 \% \\
\text { points }\end{array}$ & $\begin{array}{l}P= \\
0.0002\end{array}$ & $77.1 \pm+-1.51$ & $75.5 \pm 1.95$ & $\begin{array}{l}\text { Not signif- } \\
\text { icant }\end{array}$ & $\begin{array}{l}P<0.05 \\
\text { significant }\end{array}$ \\
\hline 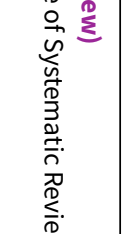 & NLIV & $\begin{array}{l}\text { resting heart rate beats } / \mathrm{min} \\
\text { mean } \pm \text { SEM }\end{array}$ & $81.1+ - \pm 1.66$ & $77.9 \pm 1.1$ & $\begin{array}{l}4.3 \\
\text { beats/ } \\
\text { min } \\
\text { (de- } \\
\text { crease) }\end{array}$ & $P=0.004$ & $85.8+ - \pm 1.7$ & $86.9 \pm 1.96$ & $\begin{array}{l}\text { Not signif- } \\
\text { icant }\end{array}$ & $\begin{array}{l}P=0.003 \\
\text { significant }\end{array}$ \\
\hline $\begin{array}{l}\frac{n}{0} \\
\frac{\bar{c}}{\overline{\bar{v}}} \\
\frac{\bar{v}}{\overline{0}} \\
0\end{array}$ & & $\begin{array}{l}\text { appetite } \\
\text { mean } \pm \text { SEM }\end{array}$ & $709+ - \pm 58$ & $841 \pm 65.2$ & $139 \mathrm{~mL}$ & $P=0.014$ & $811+ - \pm 93.4$ & $803 \pm 78$ & $\begin{array}{l}\text { Not signif- } \\
\text { icant }\end{array}$ & Nnot significant \\
\hline$\sum_{j}^{\stackrel{\circ}{0}}$ & \multirow{4}{*}{$\begin{array}{l}\text { Be- } 6 \\
\text { fi- } \mathrm{mc} \\
\mathrm{di} \\
\text { Mengue } \\
1992 \\
\mathrm{CMR}^{2}\end{array}$} & $\begin{array}{l}\text { height } \\
\text { nonths } \\
\text { median cm (SD) }\end{array}$ & $134.1(12.3)$ & $135.8(12.5)$ & & 1.6 & $132.8(12.0)$ & $134.5(12.3)$ & 1.7 & Not significant \\
\hline $\begin{array}{l}\infty \\
0 \\
0 \\
0 \\
\vdots \\
5\end{array}$ & & $\begin{array}{l}\text { weight } \\
\text { median } \mathrm{kg}(\mathrm{SD})\end{array}$ & $29.2(7.4)$ & $31.3(8.2)$ & & 2.1 & $28.3(7.2)$ & $30.2(7.9)$ & 1.9 & Not significant \\
\hline 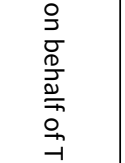 & & $\begin{array}{l}\text { middle upper arm circumfer- } \\
\text { ence (MUAC) } \\
\text { median } \mathrm{cm}(\mathrm{SD})\end{array}$ & $18.4(2.0)$ & $19.0(2.2)$ & & 0.6 & $18.3(2.1)$ & $18.7(2.2)$ & 0.4 & Significant \\
\hline 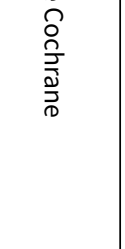 & & $\begin{array}{l}\text { triceps skinfold } \\
\text { median } \\
\text { unit not specified } \\
\text { (SD) }\end{array}$ & $6.7(1.5)$ & $7.1(1.9)$ & & 0.4 & $6.6(1.9)$ & $6.9(2.1)$ & 0.3 & Not significant \\
\hline
\end{tabular}




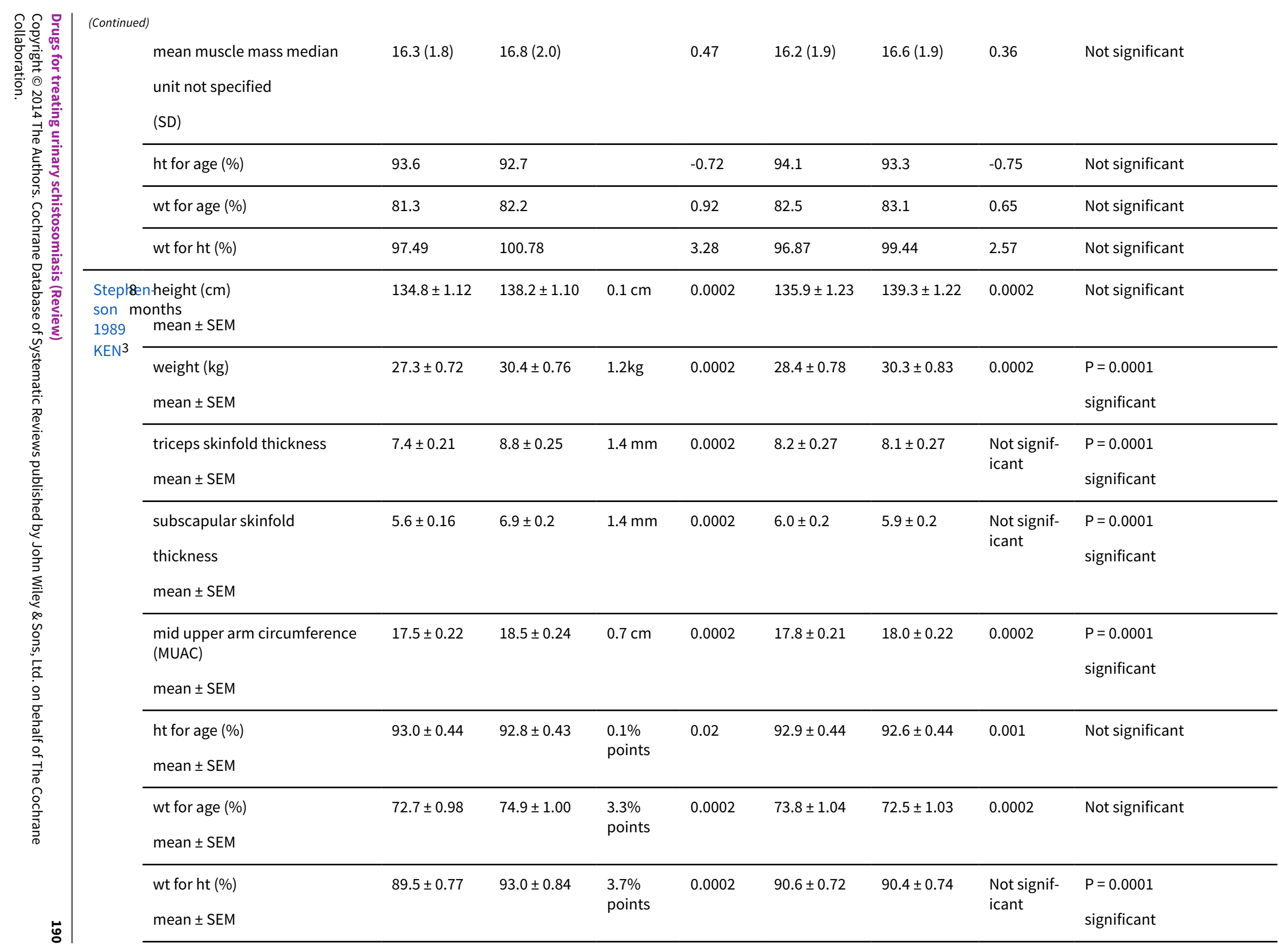




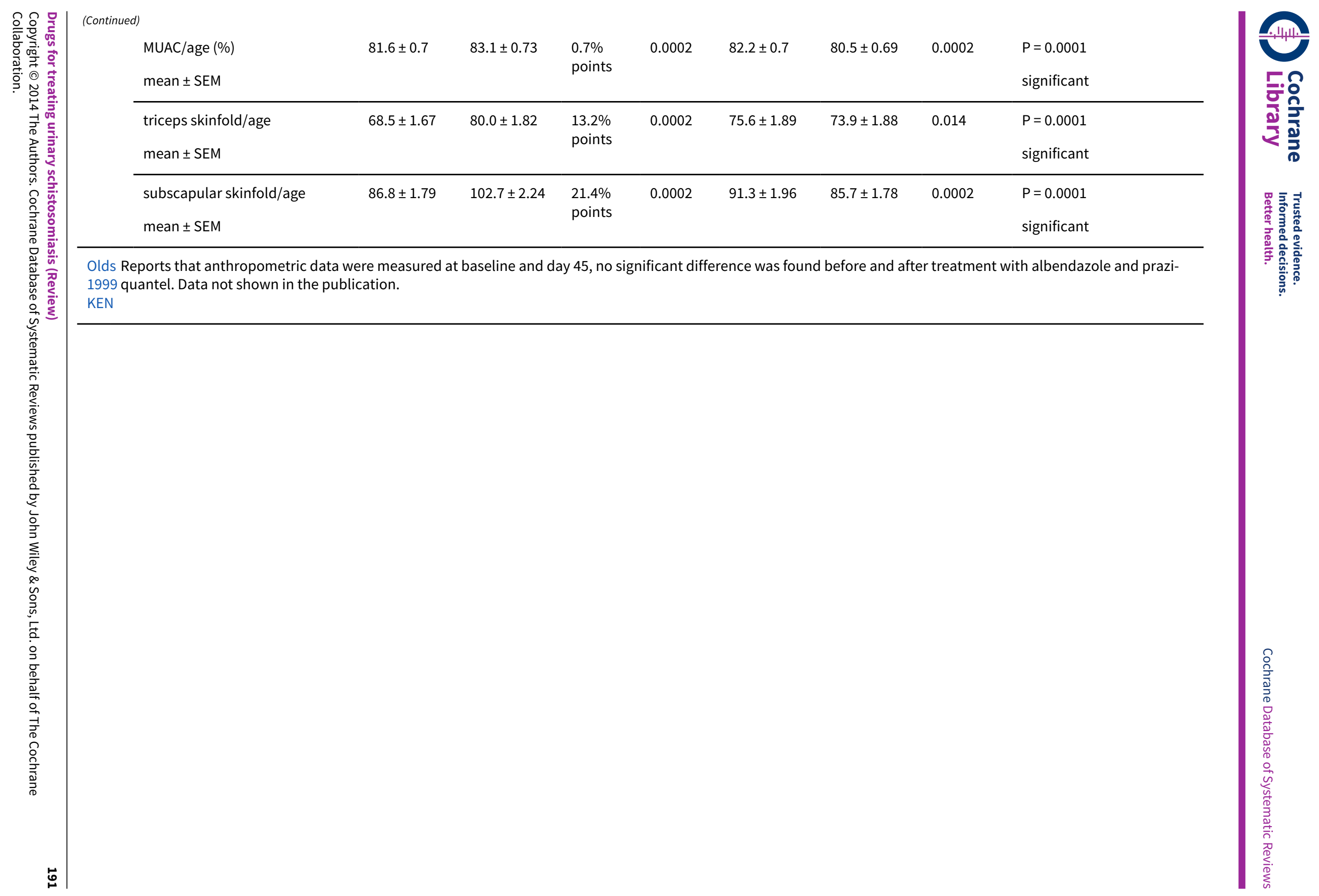


1Stephenson 1989 KEN reports growth greater than placebo. Sixteenparticipants per group are followed up at 5 weeks. Appetite measured by $\mathrm{mL}$ of porridge intake. No significant difference between metrifonate and praziquantel groups for the outcomes resting heart rate, Harvard step test and appetite.

2 Befidi Mengue 1992 CMR has 238 participants in the praziquantel group and 198 in the placebogroup. "MUAC was the only anthropometric measure with a significant difference between Praziquantel and Placebo group.". Nno significant differences (before and after interventions) between the groups for height, weight, TSS; TSS:triceps skinfold thickness, MUAC: middle upper arm circumference.

3Stephenson 1989 KEN At follow up at eight months, there are 105 participants in the praziquantel group and 104 in the placebo group.

Praziquantel $40 \mathrm{mg} / \mathrm{kg}$ or metrifonate $10 \mathrm{mg} / \mathrm{kg}$ single dose versus placebo: growth outcomes 


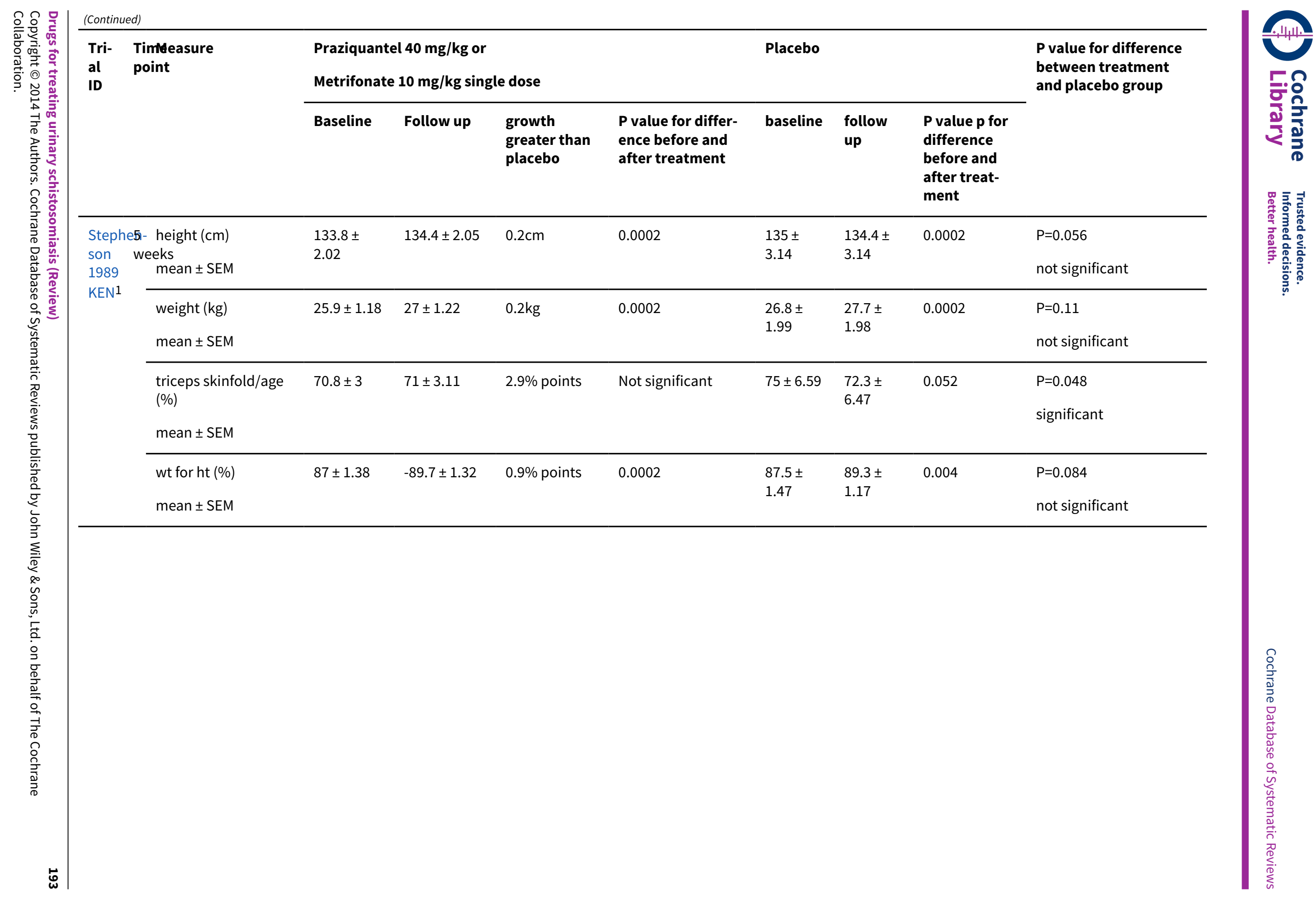


1 Stephenson 1989 KEN reports growth greater than placebo for the treatment group (praziquantel $40 \mathrm{mg} / \mathrm{kg}$ group ( $\mathrm{N}=16)$ and metrifonate $10 \mathrm{mg} / \mathrm{kg}$ group ( $\mathrm{N}=16)$ together). THe treatment group has 32 participants, the placebo group 16.

\section{Metrifonate $10 \mathrm{mg} / \mathrm{kg}$ single dose versus placebo: growth outcomes}




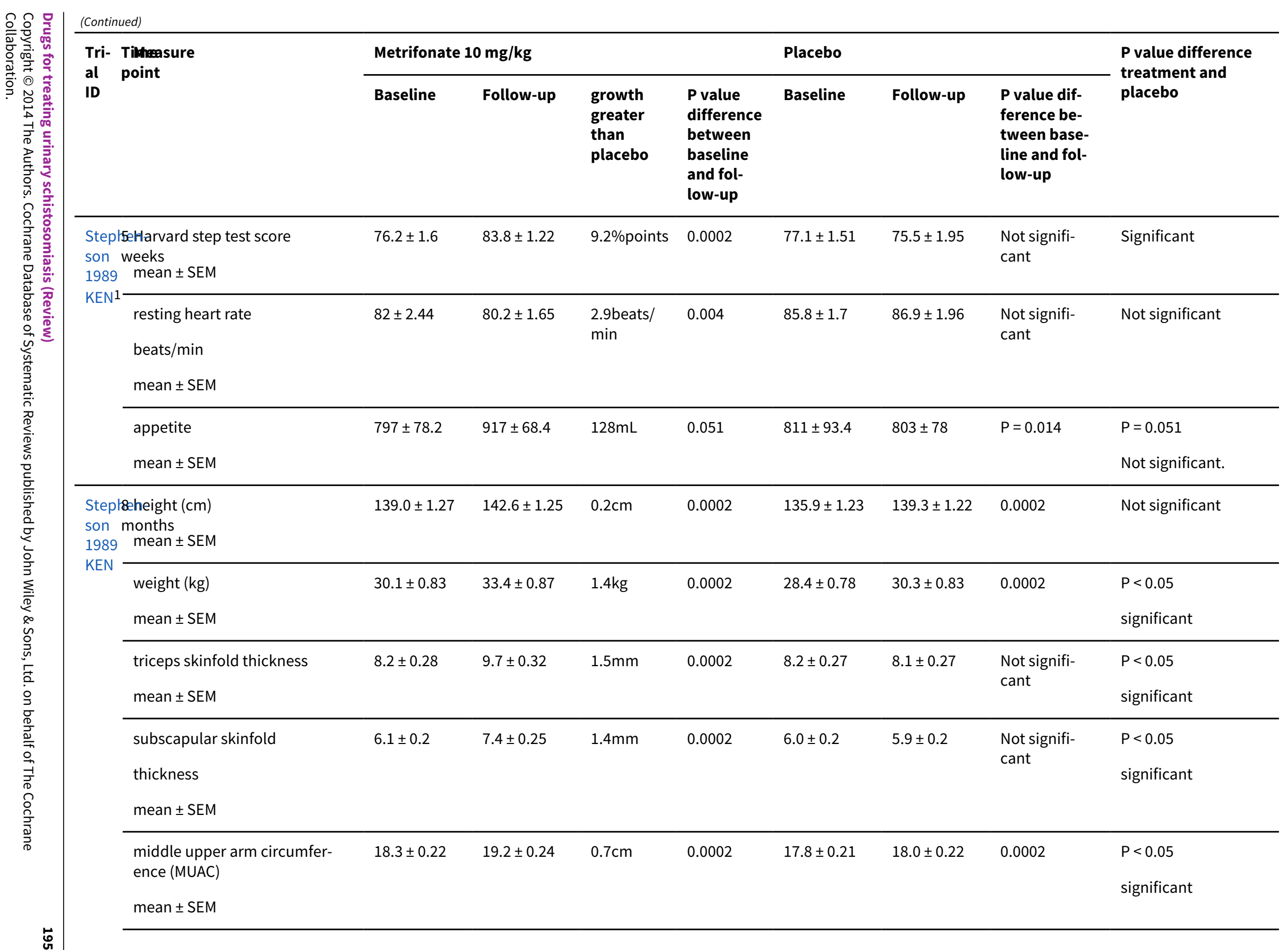




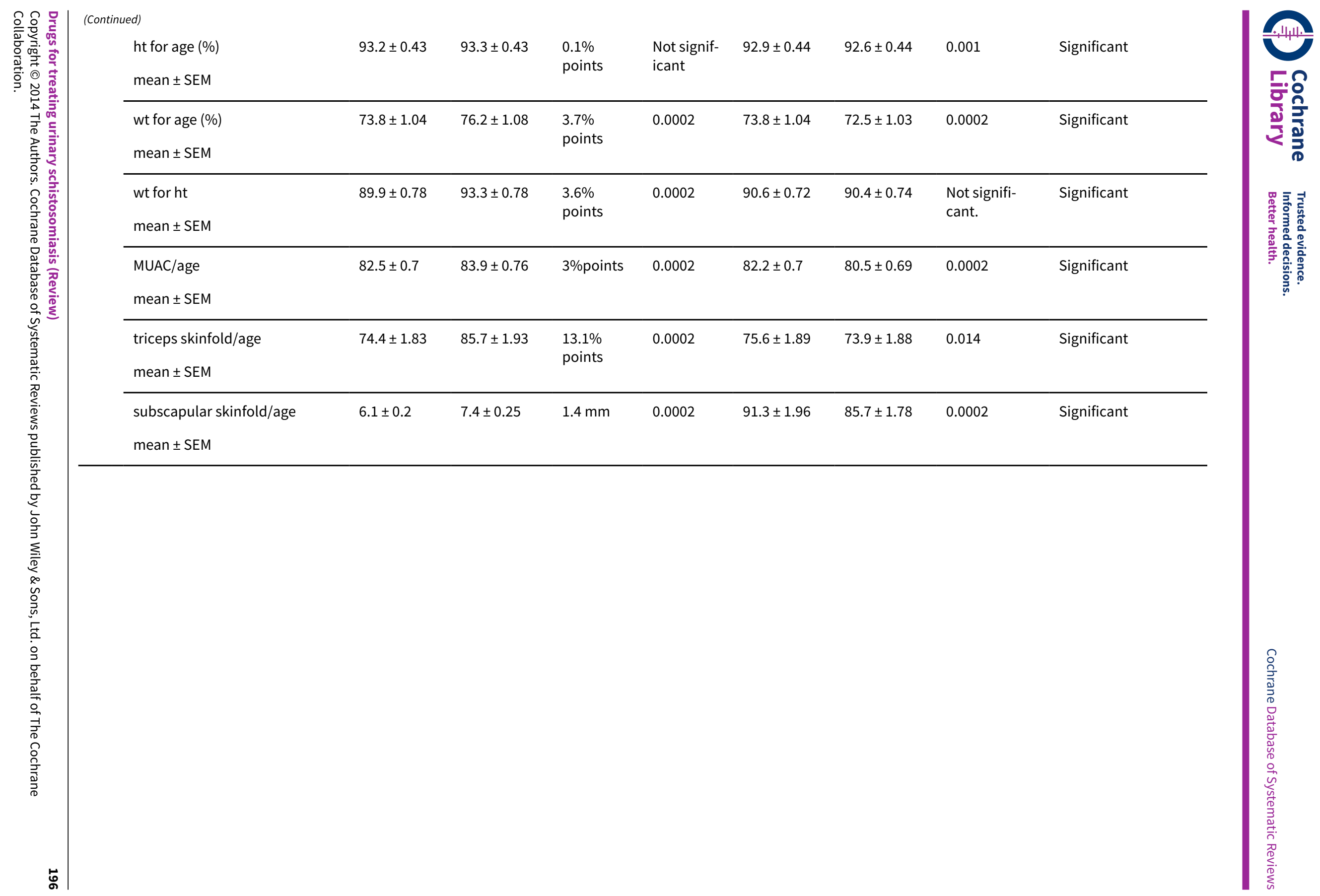


1Stephenson 1989 KEN 16 participants both in the Metrifonate $10 \mathrm{mg}$ group is and placebo group

2Stephenson 1989 KEN 103 particpants in the Metrifonate $10 \mathrm{mg}$ group, 104 participants in the placebogroup

Praziquantel $40 \mathrm{mg} / \mathrm{kg}$ single dose versus metrifonate $10 \mathrm{mg} / \mathrm{kg}$ single dose: growth outcomes 


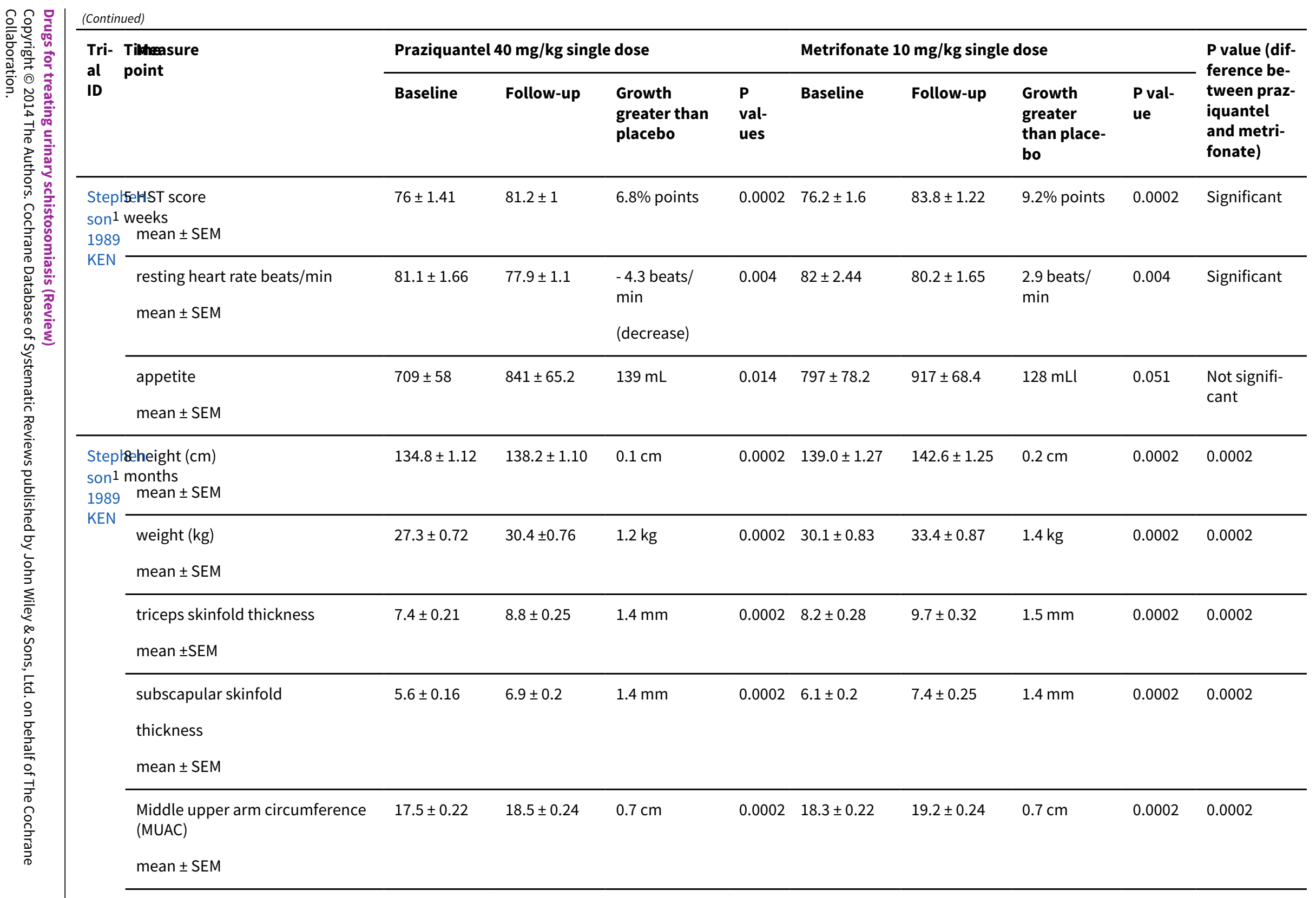




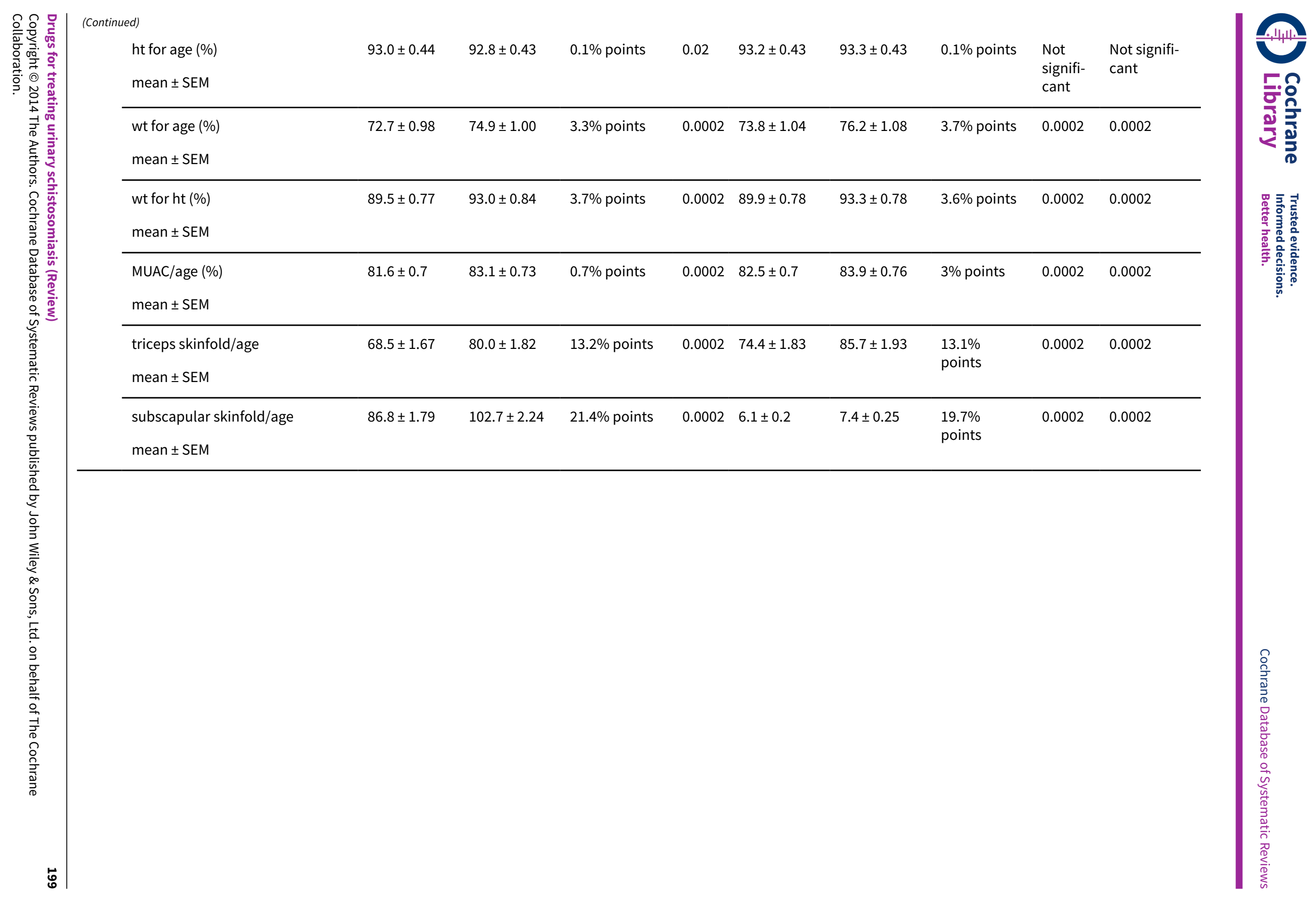


Stephenson 1989 KEN at 5 weeks, there were 16 participants in the praziquantel group and 16 in the metrifonate group. At 8 months, there were 105 participants in the praziquantel group and 103 in the metrifonate group.

\section{Appendix 5. Appendix: Additional tables for adverse events}

Praziquantel $40 \mathrm{mg} / \mathrm{kg}$ single dose versus placebo: adverse events

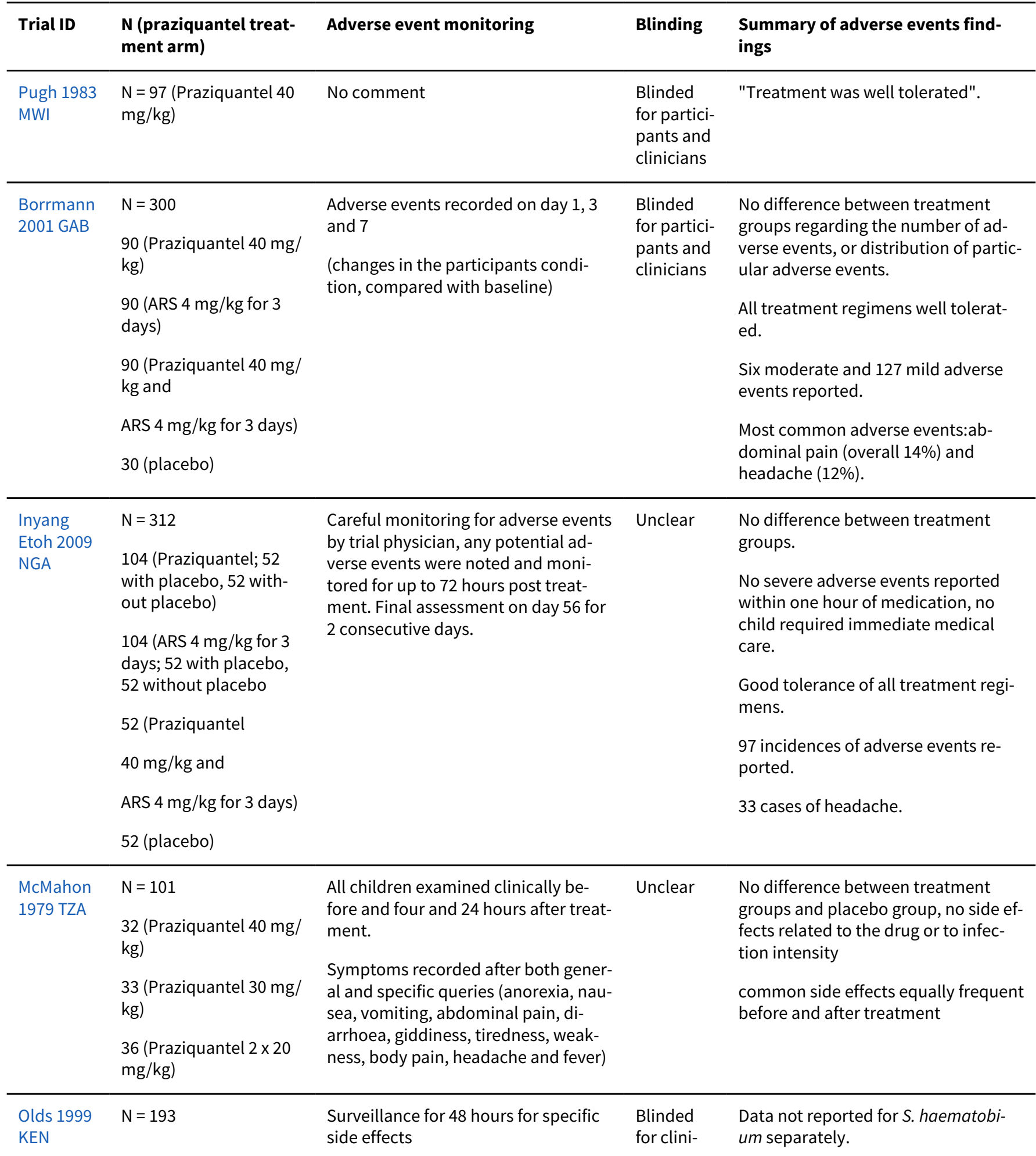


(Continued)

98 (Praziquantel and albendazole)

95 (Praziquantel) (drug-related side effect compared with parasite egg counts, symptoms over the past two weeks, physical examination and treatment group).

Participants asked for overall rating of side effects and limitations of activity

recording of request for medication for symptoms and hospitalisation. cians, par- Vomiting, abdominal pain, headache, ticipants interference with normal activity, diarrhoea, bloody diarrhoea, request not blind- for additional medication for symped for out- toms, and total side effects were all come as- higher in children with documented sessors schistosomiasis.

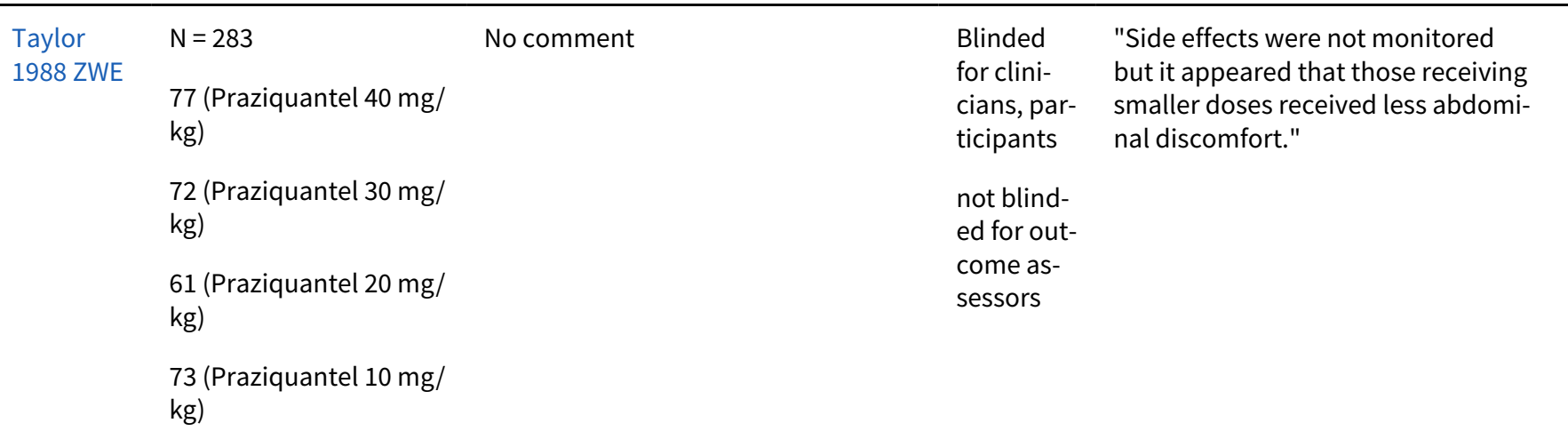

\section{Footnotes}

Befidi Mengue 1992 CMRand Stephenson 1989 KEN did not comment on adverse events.

Praziquantel $40 \mathrm{mg} / \mathrm{kg}$ single dose versus $30 \mathrm{mg} / \mathrm{kg}$ single dose: adverse events

\begin{tabular}{|c|c|c|c|c|}
\hline Trial ID & $\mathbf{N}$ & Adverse event monitoring & Blinding & Summary of adverse event finding \\
\hline $\begin{array}{l}\text { Rey } 1983 \\
\text { NER }\end{array}$ & $\begin{array}{l}\mathrm{N}=103 \\
57 \text { (Praziquantel } \\
40 \mathrm{mg} / \mathrm{kg}) \\
46 \text { (Praziquantel } \\
30 \mathrm{mg} / \mathrm{kg})\end{array}$ & Not described & Unclear & $\begin{array}{l}6 \% \text { had mild adverse events, no differ- } \\
\text { ence between groups. }\end{array}$ \\
\hline $\begin{array}{l}\text { Davis } \\
1981 \mathrm{ZMB}\end{array}$ & $\begin{array}{l}\mathrm{N}=98 \\
\mathrm{~N}=45 \text { (Prazi- } \\
\text { quantel } 40 \mathrm{mg} / \\
\mathrm{kg}) \\
\mathrm{N}=53 \text { (Prazi- } \\
\text { quantel } 30 \mathrm{mg} / \\
\mathrm{kg} \text { ) }\end{array}$ & $\begin{array}{l}\text { Active surveillance of frequency and } \\
\text { severity of side effects after treatment } \\
\text { by direct questioning. } \\
\text { Prospective: paired examinations of pre } \\
\text { and post treatment measurements and } \\
\text { haematological and clinical chemical } \\
\text { variables before and after treatment }\end{array}$ & $\begin{array}{l}\text { Single } \\
\text { blind } \\
\text { no blind- } \\
\text { ing out } \\
\text { outcome } \\
\text { assessors }\end{array}$ & $\begin{array}{l}\text { Very good tolerance and patient accept- } \\
\text { ability for praziquantel; low incidence } \\
\text { and severity of side effects. }\end{array}$ \\
\hline $\begin{array}{l}\text { McMahon } \\
1979 \text { TZA }\end{array}$ & $\begin{array}{l}\mathrm{N}=65 \\
\mathrm{~N}=32 \text { (Prazi- } \\
\text { quantel } 40 \mathrm{mg} / \\
\mathrm{kg} \text { ) }\end{array}$ & $\begin{array}{l}\text { All children examined clinically before } \\
\text { and four and } 24 \text { hours after treatment. } \\
\text { Symptoms recorded after both general } \\
\text { and specific queries. } \\
\text { Active surveillance, likely to be prospec- } \\
\text { tive. }\end{array}$ & Unclear & $\begin{array}{l}\text { No difference between groups. } \\
\text { Common side effects equally frequent be- } \\
\text { fore and after treatment and in treated } \\
\text { and placebo groups. }\end{array}$ \\
\hline
\end{tabular}


(Continued)

33 (Praziquantel $30 \mathrm{mg} / \mathrm{kg}$ )
No side effects related to the drug or to infection intensity.

\begin{tabular}{|c|c|c|c|c|}
\hline $\begin{array}{l}\text { Omer } \\
1981 \text { SDN }\end{array}$ & $\begin{array}{l}\mathrm{N}=100 \\
\mathrm{~N}=50 \text { (Prazi- } \\
\text { quantel } 40 \mathrm{mg} / \\
\mathrm{kg}) \\
\mathrm{N}=50 \text { (Prazi- } \\
\text { quantel } 30 \mathrm{mg} / \\
\mathrm{kg})\end{array}$ & $\begin{array}{l}\text { Side effects recorded before and after } \\
\text { treatment. } \\
\text { Method of monitoring not described. } \\
\text { Monitoring of vital signs (pulse rate, res- } \\
\text { piratory rate, blood pressure) at } 24 \text { and } \\
48 \text { hours. }\end{array}$ & $\begin{array}{l}\text { Unclear } \\
\text { for par- } \\
\text { ticipants, } \\
\text { clinicians } \\
\text { and out- } \\
\text { come as- } \\
\text { sessors }\end{array}$ & $\begin{array}{l}\text { Difference between groups not reported. } \\
\text { Mild diarrhoea on day one following } \\
\text { treatment in } 31 \% \text { of patients. } \\
\text { All other symptoms mild and transient. }\end{array}$ \\
\hline $\begin{array}{l}\text { Oyediran } \\
1981 \text { NGA }\end{array}$ & $\begin{array}{l}\mathrm{N}=22 \text { Prazi- } \\
\text { quantel } 40 \mathrm{mg} / \\
\mathrm{kg} \\
\mathrm{N}=23 \text { (Prazi- } \\
\text { quantel } 30 \mathrm{mg} / \\
\mathrm{kg} \text { ) } \\
\mathrm{N}=21 \text { (Prazi- } \\
\text { quantel } 2 \times 20 \\
\mathrm{mg} / \mathrm{kg} \text { ) } \\
\mathrm{N}=24 \text { (placebo) }\end{array}$ & $\begin{array}{l}\text { Clinical examination pre-treatment and } \\
18 \text { to } 24 \text { hours post treatment to detect } \\
\text { any unwanted side effects of praziquan- } \\
\text { tel (pulse rate, systolic and diastolic } \\
\text { blood pressure). } \\
\text { Haematological and biochemical blood } \\
\text { tests before (standard blood count, } \\
\text { Hb electrophoresis, Bilirubin, SGPT, } \\
\text { SGOT) and } 18 \text { to } 24 \text { hours after treat- } \\
\text { ment (packed cell volume, total and dif- } \\
\text { ferential white blood count, Bilirubin, } \\
\text { SGOT, SGPT). } \\
\text { Therapeutic doses of chloroquine (for } \\
\text { Malaria) and levo-tetramisole (ascaria- } \\
\text { sis) given to all subjects. }\end{array}$ & Unclear & $\begin{array}{l}\text { Difference in clinically diagnosed side ef- } \\
\text { fects not reported. } \\
\text { No difference between groups in post } \\
\text { treatment haematological and biochemi- } \\
\text { cal findings (within normal limits). } \\
\text { Very good tolerance of praziquantel, very } \\
\text { few side effects (two cases of moderate } \\
\text { abdominal pain). }\end{array}$ \\
\hline $\begin{array}{l}\text { Taylor } \\
1988 \\
\text { ZWE1 }\end{array}$ & $\begin{array}{l}283 \\
77 \text { (Praziquantel } \\
40 \text { mg/kg), } \\
72 \text { (Praziquantel } \\
30 \text { mg/kg) }\end{array}$ & No comment & $\begin{array}{l}\text { Blinded } \\
\text { for clini- } \\
\text { cians, par- } \\
\text { ticipants. } \\
\text { Not blind- } \\
\text { ed for out- } \\
\text { come as- } \\
\text { sessors. }\end{array}$ & $\begin{array}{l}\text { "Side effects were not monitored but it } \\
\text { appeared that those receiving smaller } \\
\text { doses received less abdominal discom- } \\
\text { fort." }\end{array}$ \\
\hline
\end{tabular}

\section{Footnotes}

King 2002 KEN, Mott 1985 GHA, King 2002 KEN and Wilkins 1987 GMB did not report adverse events.

1Taylor 1988 ZWE also reported a treatment arm of 61 participants who received Praziquantel $20 \mathrm{mg} / \mathrm{kg}$ and a treatment arm of 73 participants who received Praziquantel $10 \mathrm{mg} / \mathrm{kg}$.

\section{Praziquantel single dose versus split doses: adverse events}

\begin{tabular}{lllll}
\hline Trial ID & $\begin{array}{l}\text { N (praz- } \\
\text { iquantel } \\
\text { treatment } \\
\text { arm) }\end{array}$ & Adverse event monitoring & Blinding & $\begin{array}{l}\text { Summary of adverse events find- } \\
\text { ings }\end{array}$ \\
\hline $\begin{array}{l}\text { Kardaman } \\
1985 \text { SDN }\end{array}$ & $N=220$ & Monitoring & Unclear & $\begin{array}{l}80 \% \text { of children with some mild, tran- } \\
\text { sitory drug-induced side-effects. }\end{array}$
\end{tabular}


(Continued)

114 (Prazi- Pre-treatment clinical examination and interquantel $40 \quad$ view of all patients by a clinician at the school $\mathrm{mg} / \mathrm{kg}$ on the day prior to treatment. recording of pre-

106 (Praziquantel $2 x$ $20 \mathrm{mg} / \mathrm{kg}$ ) treatment symptoms per group.

Post-treatment interview of patients the morning after treatment by clinicians. recording or post-treatment drug-induced side-effects

per group.

Second check seven days after treatment.

Prospective, active surveillance.
Most common complaint abdominal pain (63\%) (further complaints diarrhoea, nausea, vomiting).

Vomiting and dizziness significantly less common with a single dose than a split dose (resolved within 24 hours).

\begin{tabular}{|c|c|c|c|c|}
\hline $\begin{array}{l}\text { McMahon } \\
1979 \text { TZA }\end{array}$ & $\begin{array}{l}\mathrm{N}=68 \\
32 \text { (Prazi- } \\
\text { quantel } 40 \\
\mathrm{mg} / \mathrm{kg} \text { ) } \\
36 \text { (Prazi- } \\
\text { quantel } 2 \mathrm{x} \\
20 \mathrm{mg} / \mathrm{kg} \text { ) }\end{array}$ & $\begin{array}{l}\text { All children examined clinically before, and } \\
\text { four and } 24 \text { hours after treatment. Symptoms } \\
\text { recorded after both general and specific queries } \\
\text { (anorexia, nausea, vomiting, abdominal pain, di- } \\
\text { arrhoea, giddiness, tiredness, weakness, body } \\
\text { pain, headache and fever). } \\
\text { Prospective, active surveillance, likely to be } \\
\text { prospective. }\end{array}$ & Unclear & $\begin{array}{l}\text { No side effects related to the drug or } \\
\text { to infection intensity. } \\
\text { Common side effects equally fre- } \\
\text { quent before and after treatment and } \\
\text { in treated and placebo groups. }\end{array}$ \\
\hline $\begin{array}{l}\text { Davis } \\
1981 \text { ZMB }\end{array}$ & $\begin{array}{l}\mathrm{N}=98 \\
45 \text { (Prazi- } \\
\text { quantel } 40 \\
\mathrm{mg} / \mathrm{kg} \text { ), } \\
53 \text { (Prazi- } \\
\text { quantel } 2 \mathrm{x} \\
20 \mathrm{mg} / \mathrm{kg} \text { ) }\end{array}$ & $\begin{array}{l}\text { Active surveillance of frequency and severity of } \\
\text { side effects after treatment direct questioning. } \\
\text { Prospective monitoring: paired examinations } \\
\text { of pre and post treatment measurements and } \\
\text { haematological and clinical chemical variables } \\
\text { before and after treatment. }\end{array}$ & $\begin{array}{l}\text { Single } \\
\text { blind } \\
\text { No blind- } \\
\text { ing of out- } \\
\text { come as- } \\
\text { sessors }\end{array}$ & $\begin{array}{l}\text { Very good tolerance and patient ac- } \\
\text { ceptability for praziquantel. Low inci- } \\
\text { dence and severity of side effects. }\end{array}$ \\
\hline
\end{tabular}

Metrifonate 3 doses two weeks apart: $7.5 \mathrm{mg} / \mathrm{kg}$ versus $5 \mathrm{mg} / \mathrm{kg}$ : adverse events

\begin{tabular}{|c|c|c|c|c|}
\hline Trial ID & $\begin{array}{l}\mathrm{N} \text { (met- } \\
\text { rifonate } \\
\text { treatment } \\
\text { arm) }\end{array}$ & Adverse event monitoring & Blinding & Summary of adverse events findings \\
\hline $\begin{array}{l}\text { Abden Ab- } \\
\text { di } 1989 \\
\text { SOM }\end{array}$ & $\begin{array}{l}\mathrm{N}=201 \\
100(3 \times 7.5 \\
\mathrm{mg} / \mathrm{kg}) \\
101(3 \times 5 \\
\mathrm{mg} / \mathrm{kg})\end{array}$ & $\begin{array}{l}\text { Patients left as soon as they had re- } \\
\text { ceived the drug; good monitoring during } \\
\text { the first day ( } 3 \times 5 \mathrm{mg} / \mathrm{kg} \text { given in one } \\
\text { day) } \\
\text { Questioning about side effects when pa- } \\
\text { tient returned for the next treatment } \\
\text { with a check list; spontaneous reports } \\
\text { were also noted (active and passive sur- } \\
\text { veillance). }\end{array}$ & $\begin{array}{l}\text { Double } \\
\text { blinded }\end{array}$ & $\begin{array}{l}\text { Side effects in } 7 \% \text { of patients in the } 3 \times 7.5 \mathrm{mg} / \\
\mathrm{kg} \text { treatment group and } 9 \% \text { patients in the } 3 \times 5 \\
\mathrm{mg} / \mathrm{kg} \text { treatment group; mostly mild and tran- } \\
\text { sient, headache and abdominal pain were most } \\
\text { frequently noted (Analysis 9.2). }\end{array}$ \\
\hline
\end{tabular}

Praziquantel $40 \mathrm{mg} / \mathrm{kg}$ single dose versus 3 x metrifonate $10 \mathrm{mg} / \mathrm{kg}$ : adverse events 


\begin{tabular}{|c|c|c|c|c|}
\hline Trial ID & $\begin{array}{l}\mathrm{N} \text { (metrifonate treat- } \\
\text { ment arm) }\end{array}$ & $\begin{array}{l}\text { Adverse event monitor- } \\
\text { ing }\end{array}$ & Blinding & Summary of adverse events findings \\
\hline \multirow[t]{2}{*}{$\begin{array}{l}\text { Al Aska } \\
1990 \text { SAU }\end{array}$} & $\begin{array}{l}\mathrm{N}=100 \\
50 \text { (metrifonate } 3 \times 10 \mathrm{mg} / \\
\mathrm{kg} \text { ) }\end{array}$ & \multirow[t]{2}{*}{$\begin{array}{l}\text { Recording of drug side ef- } \\
\text { fects at the second visit } \\
\text { (time point unclear) }\end{array}$} & \multirow[t]{2}{*}{ Unclear } & \multirow[t]{2}{*}{$\begin{array}{l}\text { Dizziness was more common in the prazi- } \\
\text { quantel group ( } 20 \%) \text { than in the metrifonate } \\
\text { group }(10 \%) \text {. No difference between groups } \\
\text { for abdominal pain ( } 12 \% \text { in both groups ). }\end{array}$} \\
\hline & $\begin{array}{l}50 \text { (praziquantel } 1 \times 40 \\
\mathrm{mg} / \mathrm{kg} \text { ) }\end{array}$ & & & \\
\hline
\end{tabular}

de Jonge 1990 SDN did not comment on adverse events.

Praziquantel $30 \mathrm{mg} / \mathrm{kg}$ single dose versus 3 x metrifonate $10 \mathrm{mg} / \mathrm{kg}$ : adverse events

\begin{tabular}{|c|c|c|c|c|}
\hline Trial ID & $\mathbf{N}$ (metrifonate treatment arm) & $\begin{array}{l}\text { Adverse } \\
\text { event } \\
\text { monitor- } \\
\text { ing }\end{array}$ & Blinding & Summary of adverse events findings \\
\hline \multirow{3}{*}{$\begin{array}{l}\text { McMahon } \\
1983 \text { TZA }\end{array}$} & $N=60$ & - & No & No major side effects. \\
\hline & 30 (metrifonate 3 × 10 mg/kg) & & & $\begin{array}{l}\text { "Abdominal pain was more common and } \\
\text { more severe after metrifonate." }\end{array}$ \\
\hline & 30 (praziquantel 1 × 30 mg/kg) & & & \\
\hline
\end{tabular}

Artesunate versus placebo, praziquantel and artesunate versus praziquantel: adverse events

\begin{tabular}{|c|c|c|c|c|}
\hline Trial ID & $\mathbf{N}$ (treatment arms) & Adverse event monitoring & $\begin{array}{l}\text { Blinding } \\
\text { of partici- } \\
\text { pants and } \\
\text { staff }\end{array}$ & $\begin{array}{l}\text { Summary of adverse events } \\
\text { findings }\end{array}$ \\
\hline $\begin{array}{l}\text { Borrmann } \\
2001 \mathrm{GAB}\end{array}$ & $\begin{array}{l}\mathrm{N}=300 \\
90 \text { (praziquantel } 40 \mathrm{mg} / \mathrm{kg} \text { ) } \\
90 \text { (artesunate } 4 \mathrm{mg} / \mathrm{kg} \text { for } 3 \\
\text { days) } \\
90 \text { (praziquantel } 40 \mathrm{mg} / \mathrm{kg} \\
\text { and } \\
\text { artesunate } 4 \mathrm{mg} / \mathrm{kg} \text { for } 3 \\
\text { days) } \\
30 \text { (placebo) }\end{array}$ & $\begin{array}{l}\text { Adverse events recorded on day } 1,3 \\
\text { and } 7 \\
\text { (changes in the participants condition, } \\
\text { compared with baseline). } \\
\text { Prospective surveillance. } \\
\text { Unclear if active or passive monitoring. }\end{array}$ & $\begin{array}{l}\text { Blinded } \\
\text { for partici- } \\
\text { pants and } \\
\text { clinicians }\end{array}$ & $\begin{array}{l}\text { All treatment regimens well } \\
\text { tolerated. Six moderate and } \\
127 \text { mild adverse events re- } \\
\text { ported. } \\
\text { No difference between treat- } \\
\text { ment groups regarding the } \\
\text { number of adverse events, } \\
\text { or distribution of particular } \\
\text { adverse events, most com- } \\
\text { mon adverse events: abdom- } \\
\text { inal pain (overall } 14 \%) \text { and } \\
\text { headache (12\%). }\end{array}$ \\
\hline $\begin{array}{l}\text { Inyang } \\
\text { Etoh } 2009 \\
\text { NGA }\end{array}$ & $\begin{array}{l}\mathrm{N}=312 \\
104 \text { (praziquantel; } 52 \text { with } \\
\text { placebo, } 52 \text { without placebo) }\end{array}$ & $\begin{array}{l}\text { Careful monitoring for adverse events } \\
\text { by trial physician, any potential ad- } \\
\text { verse events were noted and moni- } \\
\text { tored for up to } 72 \text { hours post treat- } \\
\text { ment, excellent compliance for report- } \\
\text { ing. }\end{array}$ & Unclear & $\begin{array}{l}\text { No difference between treat- } \\
\text { ment groups. } \\
\text { No severe adverse events re- } \\
\text { ported within one hour of }\end{array}$ \\
\hline
\end{tabular}


(Continued)

104 (artesunate $4 \mathrm{mg} / \mathrm{kg}$ for 3 days; 52 with placebo, 52 without placebo)

52 (praziquantel $40 \mathrm{mg} / \mathrm{kg}$ and artesunate $4 \mathrm{mg} / \mathrm{kg}$ for 3 days)

52 (placebo)
Final assessment on day 56 for 2 consecutive days.

Unclear if active or passive monitoring. medication, no child required immediate medical care.

97 incidences of adverse events reported

33 cases of headache

Good tolerance of all treatment regimens

\section{Praziquantel versus artesunate: adverse events}

\begin{tabular}{|c|c|c|c|c|}
\hline Trial ID & $\mathbf{N}$ (treatment arms) & Adverse event monitoring & $\begin{array}{l}\text { Blinding } \\
\text { of partici- } \\
\text { pants and } \\
\text { staff }\end{array}$ & Summary of adverse events findings \\
\hline $\begin{array}{l}\text { Keiser } \\
2010 \text { CIV }\end{array}$ & $\begin{array}{l}\mathrm{N}=83 \\
19 \text { (mefloquine } 25 \mathrm{mg} / \\
\mathrm{kg} \text { ) } \\
18 \text { (artesunate } 3 \times 100 \\
\mathrm{mg} \text { and mefloquine } 250 \\
\mathrm{mg} \text { FDC) } \\
20 \text { (artesunate } 4 \mathrm{mg} / \mathrm{kg} \\
\text { for } 3 \text { days) } \\
26 \text { (praziquantel } 40 \mathrm{mg} / \\
\mathrm{kg} \text { ) } \\
\text { No placebo arm }\end{array}$ & $\begin{array}{l}\text { Observation for AE for } 3 \text { hours af- } \\
\text { ter the first dose } A E \text { monitoring } \\
\text { until } 96 \text { hours after the first dos- } \\
\text { ing. } \\
\text { Interview with standardized } \\
\text { questionnaire at } 24,48,72 \text { and } 96 \\
\text { hours. } \\
\text { Clinical examination in case AE } \\
\text { occurred. } \\
\text { Classification of AE as mild, mod- } \\
\text { erate, severe or life threatening. }\end{array}$ & $\begin{array}{l}\text { Not blind- } \\
\text { ed }\end{array}$ & $\begin{array}{l}\text { No difference between the four treatment } \\
\text { groups (headache, coughing, vomiting, } \\
\text { vertigo or chills). } \\
\text { Abdominal pain more frequent in the } \\
\text { mefloquine group }(98 \%, \mathrm{P}<0.001) \text {, meflo- } \\
\text { quine-artesunate }(83 \%, \mathrm{P}=0.008 \text {, arte- } \\
\text { sunate }(60 \%, \mathrm{P}=0.37) \text { than in the prazi- } \\
\text { quantel group ( } 46 \%) \text {. } \\
\text { More participants had at least one AE in } \\
\text { any of the assessments in the mefloquine } \\
\text { group ( } 100 \%) \text {, in the mefloquine-arte- } \\
\text { sunate group ( } 94 \%) \text { and in the artesunate } \\
\text { group ( } 80 \%) \text { than in the praziquantel } \\
\text { group ( } 61 \%) \text {, } \\
\text { No serious or life-threatening adverse } \\
\text { events, no hospital admissions due to AE } \\
\text { no neuropsychological } \mathrm{AE} \text {, no trial dis- } \\
\text { continuation due to } \mathrm{AE} \text {. }\end{array}$ \\
\hline $\begin{array}{l}\text { Borrmann } \\
2001 \text { GAB }\end{array}$ & $\begin{array}{l}\mathrm{N}=300 \\
90 \text { (praziquantel } 40 \mathrm{mg} / \\
\mathrm{kg} \text { ) } \\
90 \text { (artesunate } 4 \mathrm{mg} / \mathrm{kg} \\
\text { for } 3 \text { days) } \\
90 \text { (praziquantel } 40 \mathrm{mg} / \\
\mathrm{kg} \text { and artesunate } 4 \\
\mathrm{mg} / \mathrm{kg} \text { for } 3 \text { days) } \\
30 \text { (placebo) }\end{array}$ & $\begin{array}{l}\text { Adverse events recorded on day } \\
1,3 \text { and } 7 \\
\text { (changes in the participants con- } \\
\text { dition, compared with baseline). } \\
\text { Prospective surveillance. }\end{array}$ & $\begin{array}{l}\text { Blinded } \\
\text { for partici- } \\
\text { pants and } \\
\text { clinicians }\end{array}$ & $\begin{array}{l}\text { All treatment regimens well tolerated. Six } \\
\text { moderate and } 127 \text { mild adverse events } \\
\text { were reported. } \\
\text { No difference between treatment groups } \\
\text { regarding the number of adverse events, } \\
\text { or distribution of particular adverse } \\
\text { events, most common adverse events: } \\
\text { abdominal pain (overall 14\%) and } \\
\text { headache (12\%). }\end{array}$ \\
\hline $\begin{array}{l}\text { Inyang } \\
\text { Etoh } 2009 \\
\text { NGA }\end{array}$ & $N=312$ & $\begin{array}{l}\text { Careful monitoring for adverse } \\
\text { events by trial physician, any po- } \\
\text { tential adverse events were not- }\end{array}$ & Unclear & No difference between treatment groups \\
\hline
\end{tabular}


(Continued)

104 (praziquantel; 52 with placebo, 52 without placebo)

104 (artesunate $4 \mathrm{mg}$ / $\mathrm{kg}$ for 3 days; 52 with placebo, 52 without placebo.

52 (praziquantel $40 \mathrm{mg}$ / $\mathrm{kg}$ and

artesunate $4 \mathrm{mg} / \mathrm{kg}$ for 3 days)

52 (placebo) ed and monitored for up to 72 hours post treatment.

Final assessment on day 56 for two consecutive days.

Unclear if active or passive surveillance
No severe adverse events reported within one hour of medication, no child required immediate medical care.

97 incidences of adverse events reported

33 cases of headache

Good tolerance of all treatment regimens

Praziquantel versus mefloquine: adverse events

\begin{tabular}{|c|c|c|c|c|}
\hline Trial ID & $\begin{array}{l}\mathrm{N} \text { (treatment } \\
\text { arms) }\end{array}$ & Adverse event monitoring & $\begin{array}{l}\text { Blinding } \\
\text { of partici- } \\
\text { pants and } \\
\text { staff }\end{array}$ & Summary of adverse events findings \\
\hline $\begin{array}{l}\text { Keiser } \\
2010 \text { CIV }\end{array}$ & $\begin{array}{l}\mathrm{N}=83 \\
19 \text { (mefloquine } \\
25 \mathrm{mg} / \mathrm{kg} \text { ) } \\
18 \text { (artesunate } \\
3 \times 100 \mathrm{mg} \text { and } \\
\text { mefloquine } 250 \\
\mathrm{mg} \text { FDC) } \\
20 \text { (artesunate } 4 \\
\mathrm{mg} / \mathrm{kg} \text { for } 3 \text { days) } \\
26 \text { (praziquantel } \\
40 \text { mg/kg) } \\
\text { No placebo arm }\end{array}$ & $\begin{array}{l}\text { Observation for AE for } 3 \text { hours } \\
\text { after the first dose AE monitor- } \\
\text { ing until } 96 \text { hours after the first } \\
\text { dosing } \\
\text { interview with standardized } \\
\text { questionnaire at } 24,48,72 \text { and } \\
96 \text { hours. } \\
\text { Clinical examination in case AE } \\
\text { occurred. } \\
\text { Classification of AEs as mild, } \\
\text { moderate, severe or life } \\
\text { threatening. }\end{array}$ & $\begin{array}{l}\text { Not blind- } \\
\text { ed }\end{array}$ & $\begin{array}{l}\text { No difference between the four treatment groups } \\
\text { (headache, coughing, vomiting, vertigo or chills), } \\
\text { abdominal pain more frequent in the mefloquine } \\
\text { group }(98 \%, \mathrm{P}<0.001) \text {, mefloquine-artesunate } \\
\text { ( } 83 \%, \mathrm{P}=0.008 \text {, artesunate }(60 \%, \mathrm{P}=0.37) \text { than in } \\
\text { the praziquantel group ( } 46 \%) \text {. } \\
\text { More participants had at least one } \mathrm{AE} \text { in any of the } \\
\text { assessments in the mefloquine group ( } 100 \%) \text {, in } \\
\text { the mefloquine-artesunate group ( } 94 \%) \text { and in the } \\
\text { artesunate group ( } 80 \%) \text { than in the praziquantel } \\
\text { group ( } 61 \%) \text {. } \\
\text { No serious or life-threatening adverse events, no } \\
\text { hospital admissions due to } \mathrm{AE} \text {, } \\
\text { no neuropsychological } \mathrm{AE}, \text { no trial discontinuation } \\
\text { due to } \mathrm{AE} \text {. }\end{array}$ \\
\hline
\end{tabular}

Praziquantel versus Praziquantel and ALB: adverse events

\begin{tabular}{|c|c|c|c|c|}
\hline Trial ID & Participants & $\begin{array}{l}\text { Adverse events } \\
\text { monitoring }\end{array}$ & Blinding & Summary of adverse events findings \\
\hline $\begin{array}{l}\text { Olds } 1999 \\
\text { KEN }\end{array}$ & $\begin{array}{l}\mathrm{N}=193 \\
98 \text { (Praziquantel } \\
\text { and albendazole) }\end{array}$ & $\begin{array}{l}A E \text { monitoring for } \\
48 \text { hours for pre-de- } \\
\text { fined } A E\end{array}$ & $\begin{array}{l}\text { Double } \\
\text { blind }\end{array}$ & $\begin{array}{l}65 \% \text { of side effects for S. haematobium reported within four } \\
\text { to six hours. Symptoms usually resolved within two hours } \\
\text { with or without relief medication. } \\
\text { Data not reported for S. haematobium separately. }\end{array}$ \\
\hline
\end{tabular}




\section{Appendix 6. Appendix: Ultrasound findings}

Praziquantel $40 \mathrm{mg} / \mathrm{kg}$ single dose versus $20 \mathrm{mg} / \mathrm{kg}$ single dose: ultrasound findings

\begin{tabular}{|c|c|c|c|c|c|c|}
\hline \multirow[t]{2}{*}{ Trial ID } & \multirow[t]{2}{*}{$\begin{array}{l}\text { Time } \\
\text { point }\end{array}$} & \multirow[t]{2}{*}{ Measure } & \multicolumn{2}{|c|}{$\begin{array}{l}\text { Praziquantel } 40 \text { mg/kg } \\
\text { (SD) }\end{array}$} & \multicolumn{2}{|c|}{$\begin{array}{l}\text { Praziquantel } 20 \mathrm{mg} / \mathrm{kg} \\
\text { (SD) }\end{array}$} \\
\hline & & & Baseline & $\begin{array}{l}\text { Fol- } \\
\text { low-up }\end{array}$ & Baseline & $\begin{array}{l}\text { Fol- } \\
\text { low-up }\end{array}$ \\
\hline \multirow[t]{6}{*}{$\begin{array}{l}\text { King } 2002 \\
\text { KEN1 }\end{array}$} & 9 months & $\begin{array}{l}\text { Number of participants with haematuria/total } \\
N=264 \text { for both groups }\end{array}$ & $\begin{array}{l}22 / 32 \\
(69 \%)\end{array}$ & $\begin{array}{l}16 / 32 \\
(50 \%)\end{array}$ & $20 / 32(62 \%)$ & $\begin{array}{l}17 / 32 \\
(53 \%)\end{array}$ \\
\hline & & Mild hydronephrosis (\%) & $25 \%$ & $15 \%$ & $21 \%$ & $18 \%$ \\
\hline & & Moderate hydronephrosis (\%) & $5 \%$ & $4 \%$ & $11 \%$ & $0 \%$ \\
\hline & & Severe hydronephrosis (\%) & $5 \%$ & $2 \%$ & $3 \%$ & $2 \%$ \\
\hline & & Mild bladder abnormalities (\%) & $11 \%$ & $4 \%$ & $17 \%$ & $6 \%$ \\
\hline & & Severe bladder abnormalities (\%) & $8 \%$ & $0 \%$ & $6 \%$ & $0 \%$ \\
\hline
\end{tabular}

1Haematuria measured by urine dipstick, "no statistical difference", "study might be underpowered, for ultrasound findings" all severe bladder abnormalities were eliminated.

Praziquantel $40 \mathrm{mg} / \mathrm{kg}$ 1x/year versus metrifonate $10 \mathrm{mg} / \mathrm{kg}$ 3x/year: ultrasound findings

\begin{tabular}{|c|c|c|c|c|c|}
\hline Trial ID & $\begin{array}{l}\text { Time } \\
\text { point }\end{array}$ & Measure & $\begin{array}{l}\text { Praziquantel } 40 \mathrm{mg} / \\
\mathrm{kg} \\
\text { 1x/year }\end{array}$ & $\begin{array}{l}\text { Metrifonate } 10 \mathrm{mg} / \mathrm{kg} \\
3 x / \text { year }\end{array}$ & Comments \\
\hline \multirow[t]{5}{*}{$\begin{array}{l}\text { King } 1990 \\
\text { KEN }\end{array}$} & \multirow[t]{5}{*}{$\begin{array}{l}12 \\
\text { months }\end{array}$} & $\begin{array}{l}\text { Bladder wall thick- } \\
\text { ness }\end{array}$ & $\begin{array}{l}35 \% \text { improvement } \\
8 \% \text { deterioration }\end{array}$ & $\begin{array}{l}29 \% \text { improvement } \\
9 \% \text { deterioration }\end{array}$ & $\begin{array}{l}\text { Subsample N = } \\
373\end{array}$ \\
\hline & & Bladder deformity & $21 \%$ improvement & $15 \%$ improvement & $\begin{array}{l}\text { Praziquantel } N= \\
141\end{array}$ \\
\hline & & & $6 \%$ deterioration & $2 \%$ deterioration & \multirow[t]{3}{*}{$\begin{array}{l}\text { Metrifonate } N= \\
126\end{array}$} \\
\hline & & Hydronephrosis & $12 \%$ improvement & $9 \%$ improvement & \\
\hline & & & $13 \%$ deterioration & $7 \%$ deterioration & \\
\hline
\end{tabular}

\section{WHAT'S NEW}




\begin{tabular}{lll}
\hline Date & Event & Description \\
\hline 7 July 2014 & New search has been performed & $\begin{array}{l}\text { The review has been updated and revised with a new author } \\
\text { team. }\end{array}$ \\
\hline 7 July 2014 & $\begin{array}{l}\text { New citation required but conclusions } \\
\text { have not changed }\end{array}$ & A new author team was put in place for this review update. \\
\hline
\end{tabular}

\section{CONTRIBUTIONS OF AUTHORS}

VK developed the protocol with input from PG and DS. VK and FZ assessed eligibility and extracted the data. We resolved any disagreements through discussion with DS and PG. VK entered the data and drafted the manuscript with input from DS, PG and PO. DS, PG and PO assisted in interpretation of the results and revisions of the text.

\section{DECLARATIONS OF INTEREST}

We have no known conflicts of interest.

\section{SOURCES OF SUPPORT}

\section{Internal sources}

- Liverpool School of Tropical Medicine, UK.

\section{External sources}

- This review was supported by the Department for International Development, UK.

\section{DIFFERENCES BETWEEN PROTOCOLANDREVIEW}

While inclusion criteria of the first protocol included all RCTs which studied antischistosomal drugs, we decided to change the protocol. We excluded trials which evaluated obsolete drugs as ambilhar, oltipraz and niridazole. We also excluded studies which compared a combination of praziquantel and albendazole to placebo only, as this comparison is not of interest for this review. We included trials evaluating metronidazole.

We did not contact researchers or organizations looking for unpublished studies, as stated in the protocol. We did not report parasitological outcomes at three months as primary outcomes.

The older version of this review concluded that both metrifonate and praziquantel were effective in treating urinary schistosomiasis, even if metrifonate had operational disadvantages. As implications for further research, evaluation of different metrifonate doses and regimens and of evaluation of artemisinin drugs and of combination therapy is recommended.

While we agree with these conclusions, the data on egg reduction allow some further recommendations. We have newly included three trials evaluating artemisinin drugs, and one recent trial using mefloquine, and present this new evidence here.

Additional analysis carried out in this edition of the review, which was not in the previous edition (Danso-Appiah 2008), is the presentation of egg reduction rates in summary tables.

\section{INDEX TERMS}

\section{Medical Subject Headings (MeSH)}

Anthelmintics [^therapeutic use]; Artemisinins [therapeutic use]; Artesunate; Mefloquine [therapeutic use]; Praziquantel [therapeutic use]; Randomized Controlled Trials as Topic; Schistosomiasis haematobia [ ${ }^{\star}$ drug therapy]; Trichlorfon [therapeutic use]

\section{MeSH check words}

Adult; Child; Humans 